UNIVERSIDADE DE SÃO PAULO

INSTITUTO DE GEOCIÊNCIAS

\title{
MINERALOGIA E PETROLOGIA DA ASSOCIAÇÃO ALCALINA DE SIENITOS E GRANITOS DE TIPO-A DO MACIÇO CORUPÁ (SC)
}

\author{
YURI GARIN
}

Orientador: Prof. Dr. Silvio Roberto Farias Vlach

DISSERTAÇÃO DE MESTRADO

COMISSÃO JULGADORA

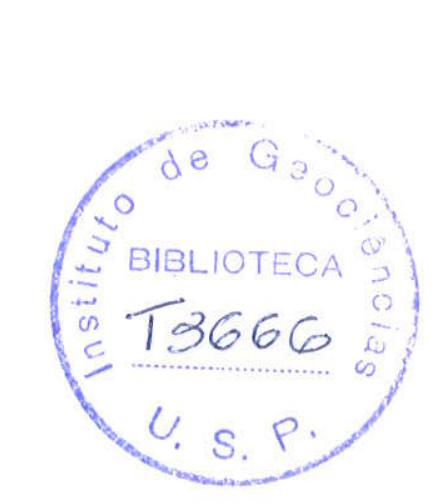

Nome
Presidente: $\quad$ Prof. Dr. Silvio Roberto Farias Vlach
Examinadores: Prof. Dr. Gilson Burigo Guimarães
Prof. Dr. Ian McReath

SÃO PAULO

2002 


\title{
UNIVERSIDADE DE SÃO PAULO INSTITUTO DE GEOCIÊNCIAS
}

\section{MINERALOGIA E PETROLOGIA DA ASSOCIAÇÃO ALCALINA DE SIENITOS E GRANITOS DE TIPO-A DO MACIÇO CORUPÁ (SC)}

\section{Yuri Garin}

\author{
Orientador: Prof. Dr. Silvio R. F. Vlach \\ DEDALUS - Acervo - IGC

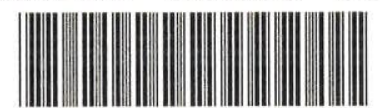 \\ 30900011132 \\ DISSERTAÇÃO DE MESTRADO
}

Programa de Pós-Graduação em Mineralogia e Petrologia

$$
\begin{gathered}
\text { SÃO PAULO } \\
2002
\end{gathered}
$$


Dedico este trabalho ao men pai Hugo (in memoriam), à minha mãe Maria Zelma, a maior incentivadora dos meus sonhos, à minha tia (e segunda mãe) Zulma e à minha companheira e porto seguro Rosane. 
Durante o tempo em que fui aluno da USP, tive a oportunidade de conhecer pessoas a quem devo agradecer, com toda sinceridade, pela amizade com que me acolheram.

Professor Silvio Vlach pela orientação, incentivo, paciência e cordialidade; fatores que foram imprescindiveis para a realização deste trabalho.

Aos amigos que deram uma grande contribuição ao longo desse tempo, incentivando e ajudando no dia-a-dia, fazendo parte desta etapa da minha vida: Tathyana Benevides, Gaston "Edir" Rojas, Rafael "Apum" Correa Silva, Paulo César Correa, Lucelene Martins, Gustavo "Torrinha" e Artur "Metanol".

Não esquecendo aqueles que se tormaram verdadeiros irmãos na minha passagem por esta Universidade: Maria da Glória Garcia, Leandro Vida, Lúcia "Docinho", Sibele, Alexandre "Chapa", Renata "Tocu", Gustavo "Troglô", Claudia "Vali", peter Howard, Klaus Petersen, Guilherme Gualda, Wemer Weber, Femando "Pobrema", Fernando "99", Fennando "Ophelia", Fernando "Bis", Rosana Peporine, Carmen "Xitah", Iede Zollinger, Gilson Burigos, Fernando "Evita", Rui "L. Palmer", Gelson "Sapo", "Chico Bill", Marcelus Glaucius, Marlei "Trilô" e Anabel Perez.

Aos Professores Caetano Juliani, Valdecir Janasi, Mabel Ulbrich, Horstpeter Ulbrich, Ian McReath, Johann Schorscher, Daniel Atencio, Excelso Ruberti, Gergely Szabó, Rômulo Machado, Colombo Tassinari e Fabio Andrade, meu muito obrigado.

Um agradecimento especial aos amigos da UFRRJ: Professores Rubem Porto Jr., Sérgio Castro Valente, Soraya Almeida e Alexis Rosa Nummer, pelo incentivo.

Aos grandes companheiros "ruralinos" Caio "Clinton", Ivanilson "Azamba", Betinho"Limpeza", Vagner "Grampa", André "Hare Krishna" e Jorge Mauro "Lobão".

Ao geólogo e amigo Jaime Mesquita (Boas Pesquisas!) pela imensurável ajuda nas etapas de campo.

Un agradecimento mais do que especial às minhas irmãs Kathyana e Katharyna, aos meus queridos sobrinhos (por alegrarem nossas vidas...) Kamila, Leticia e Hugo (esse vai ser paleontólogo!) e aos meus cunhados e grandes amigos Marcelo e Jorge.

Também aos meus sogros Sr. José e Dona Helena, que me acolheram como um filho, aqui vai o meu "Muito Obrigado!".

Aos amigos e profissionais que vestem a camisa deste Instituto e que deram toda assistência para que este trabalho acontecesse: Marcos Mansueto, Sandra Andrade, José Paulo, Ana Paula, Magali, Paulo Mori, Ricardo Cademete, Marinês Silva, Angélica, Tadeu e as equipes da laminação e da gráfica.

As populações de Corupá c laraguá do Sul pela hospitalidade e pelas belissimas cidades.

Finalmente, a CAPES, pela bolsa de mestrado concedida e a FAPESP, pelo apoio financeiro e viabilização das várias etapas desta dissertação. 


\section{INDICE}

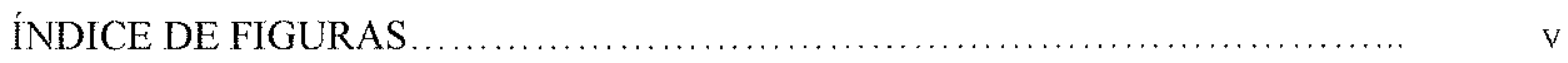

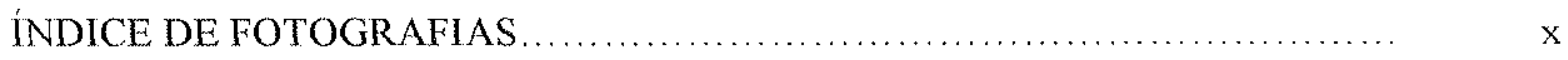

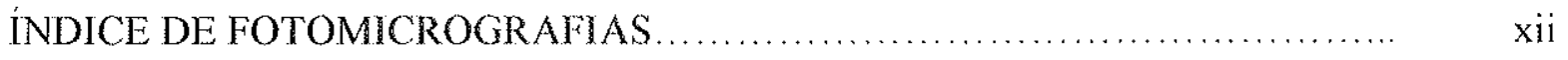

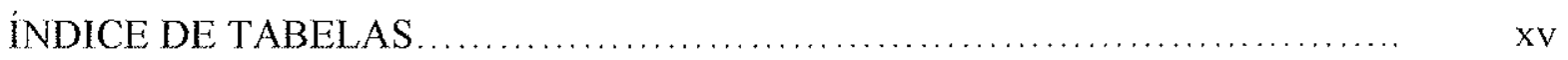

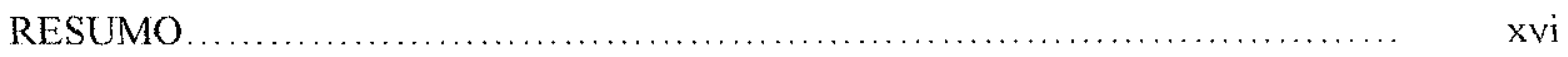

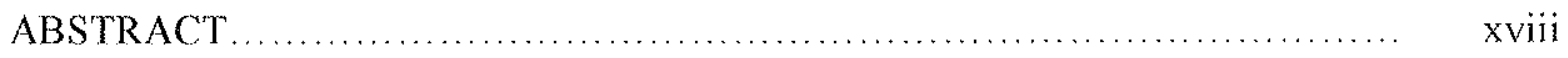

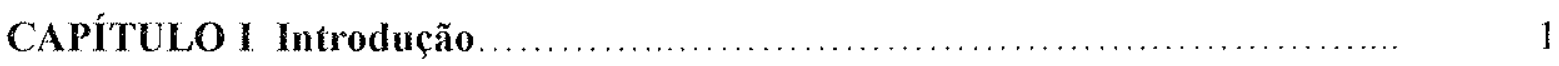

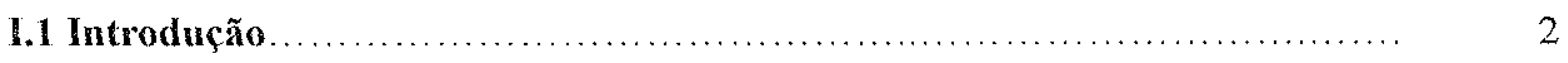

1.2 Aspectos gerais da área de estudo .................................. 5

1.3 Plano de apresentação da dissertação ................................. 7

CApítulo II Província Serra do Mar e Maciço Corupá: breve síntese de conhecimentos .............................................................. 8

II.1 As associações graníticas de Tipo-A na Província Serra do Mar...........

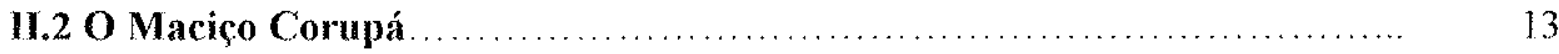

CAPÍTULO III Metodologia.......................................... 17

III.1 Trabalhos em campo ............................................ 18

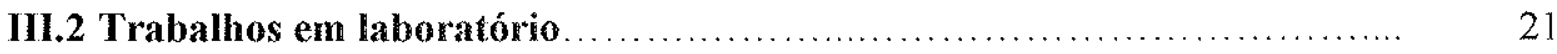

III.2.1 Análises petrográficas ......................................... 21

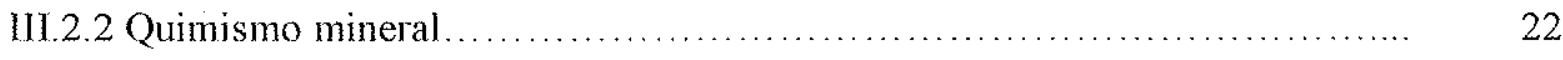

III.2.3 Análises químicas em rocha total ................................ 23 
III.2.3.1 Preparação das amostras

III.2.3.2 Fluorescência de Raios X

CAPÍtulo IV Geologia e Petrografia do Maciço Cormpá.

IV.1 Aspectos Geológicos do Maciço Corupá

IV.1.1 Variedades petrográficas: caracterização, estruturas e distribuição.

IV.1.2 Contatos geológicos e relações estruturais entre as fácies petrográficas.

IV.1.3 Zonas de cizalhamento e de falhas.

IV.1.4 Diques de microgranitos.

IV.2 Petrografia

IV.2.1 Microgranitos.

IV.2.2 Granitos de granulação média.

IV.2.3 Sienitos róseos de granulação grossa.

IV.2.4 Sienitos verdes de granulação grossa.

IV.2.5 Sienitos róseos e verdes de granulação média.

IV.2.6 Sienitos róseos de granulação fina.

IV.2.7 Melasienito

IV.2.8 Rochas dioríticas e híbridas.

IV.2.9 Enclaves monzoníticos.

IV.3 As modas das rochas do Maciço Corupá. 


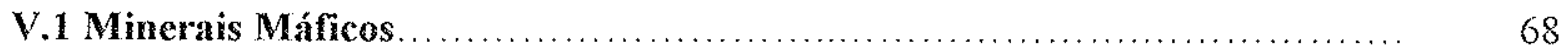

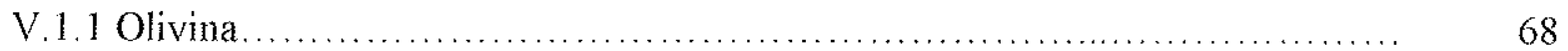

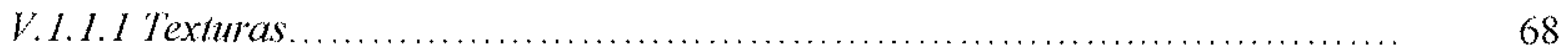

V.1.1.2 Quimismo.................................................... 69

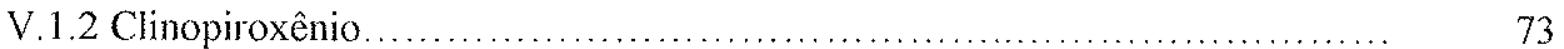

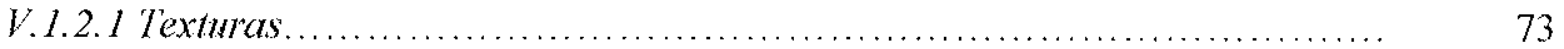

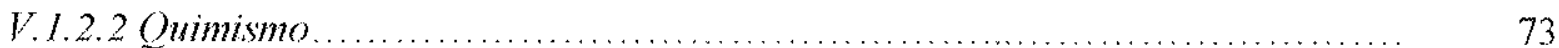

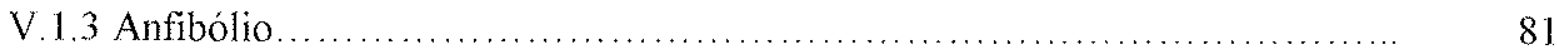

V.1.3.1 Texturas......................................................... 81

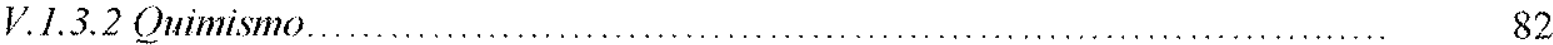

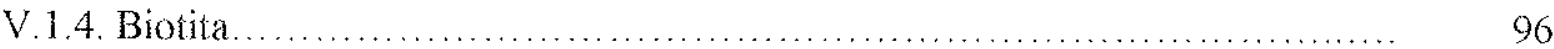

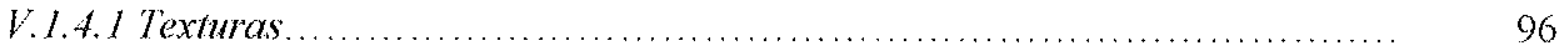

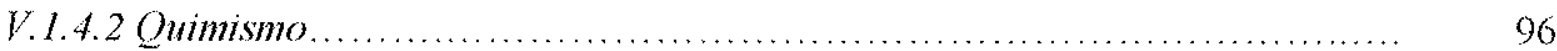

V.2 Minerais Félsicos................................................... 101

V.2.1 Plagioclásio ......................................................... 101

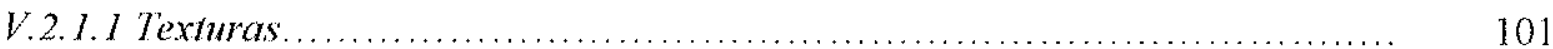

V.2.1.2 Quimismo................................................... 101

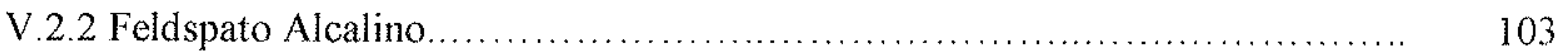

V.2.2.1 Texturas........................................................ 103

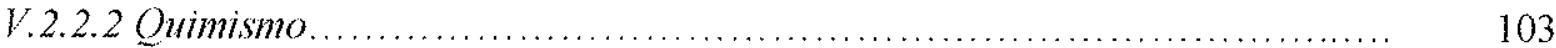


VI.1 Geoquímica de rochas ............................................ 139

VI.1.1 Apresentação dos dados .............................................. 139

VI.1.1.1 Elementos maiores e menores....................................... 139

VI.1.1.2 Mineralogia Normativa .......................................... 141

VI.1.1.3 Elementos traços............................................ 142

Vl.1.1.4 Algumas inferências extraidas da geoquimica ........................ 142

VI.1.1.5 Dados geoquinicos e diagramas discriminantes.......................... 144

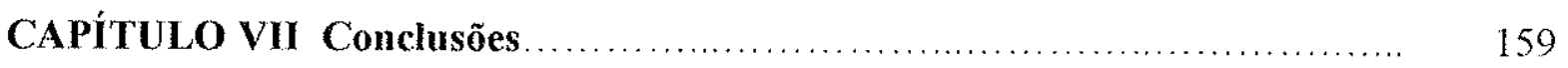

Referências Bibliográfícas ........................................... 164 


\section{ÍNDICE DE FIGURAS}

Figura I.1. Mapa indicando a localização da Suite Serra do Mar e as principais vias de acesso. Os contornos aproximados dos maciços itrusivos são destacados em azul. 1 - Granito Agudos; 2 - Granito Morro Redondo; 3 - Granito Anhangava; 4 Granitos da Graciosa; 5 - Granito Marombi; 6 - Granito Mandira; 7 - Granito Guarau; 8 - Granito Conupa; 9 - Granito Alto Turvo; 10 - Granito Dona Francisca; 11 - Granito Pirai; 12 - Granito Serra Alta; 13 - Granito Serra da lgreja. (Modificado de Kaul, 1997)

Figura 1.2. Principais vias de acesso ao (linhas cheias) Maciço Corupá (contorno tracejado), localização da áera de estudo no Estado de Santa Catarina e articulação da Folha Jaraguá do Sul. (Modificado de Oliveira, 1997)

Figura 11.1. Quadro geral das idades U-Pb, Rb-Sr e idades modelo TDM (Sm-Nd) obtidas para as rochas graníticas e sieníticas da Província Serra do Mar (segundo quadro de cima para baixo) e de unidades geológicas adjacentes. (Extraido de Siga Jr. et al., 1993).

Figura 11.2. Diagramas discriminantes selecionados para as rochas da Província Serra do Mar, caracterizando-as granitos de Tipo-A. (Extraído de Gualda, 2001)...

Figura 11.3. Diagramas de variação para elementos maiores menores e traços selecionados das rochas sieníticas e graníticas do Maciço Corupá. Triângulos: sienito fino. Quadrados meio vazados: sienito grosso. Circulos cheios: quartzo sienito. Quadrado cheio: granito.(Extraido de Kaul, 1997).

Figura II.4. Figura 11.4: Diagramas de ETR normalizados aos condritos para as rochas sieníticas e graníticas do Maciço Corupá. Triângulos: sienito fino. Quadrados meio vazados: sienito grosso. Circulos cheios: quartzo sienito. Quadrado cheio: granito. (Extraído de Kaul, 1997)

Figura VI.1. Mapa geológico esquemático, ilustrando a distribuição das fácies petrográficas no Maciço Corupá. Contatos externos baseados em Daitx (1979).....

Figura IV.2. Classificação modal das fácies petrográficas do Maciço Corupá, no diagrama Q-A-P (Streckeisen, 1973).

Figura IV.3. Diagrama de variação envolvendo o parâmetro $(\mathrm{Q} / \mathrm{FA}+\mathrm{Q})$ e o volume total de minerais máficos (\%) para as rochas das fácies granítica e sienítica.

Figura IV.4. Provável ordem de cristalização mineral das rochas graníticas do Maciço Corupá. 
Figura IV.5. Provável ordem de cristalização mineral das rochas sieniticas do Maciço Corupá.

Figura IV.6. Provável ordem de cristalização mineral das rochas de composição diorítica do Maciço Corupá.

Figura V.1. Diagrama catiônico $[(\mathrm{Mg} /(\mathrm{Fe} 2++\mathrm{Mg}) \times \mathrm{Fe} 2 \psi /(\mathrm{Fe} 2++\mathrm{Mg})]$ para classificação da olivina das fácies sienítica verde grossa e melasienítica

Figura V.2. Diagrama catiônico ( $\mathrm{Mn} \times \mathrm{Mg} \times \mathrm{Fe} 2+$ ) para olivina das fácies sienítica verde grossa e melasienítica...

Figura V.3. Diagrama catiônico $[\mathrm{Fe} 2+x \quad(\mathrm{Mg}+\mathrm{Mn})]$ ilustrando a tendência evolutiva da olivina do melasienito e do sienito verde grosso

Figura V.4. Imagem de elétrons retro-espalhados, em modo composicional, de cristais de olivina, mostrando os perfis analíticos WDS efetuados e o número de análises em cada perfill. A: fácies sienítica verde de granulação grossa. Observar inclusões de apatita em cinza médio e ilmenita em claro. B: fácies melasienítica, também com inclusôes de apatita; cristais mais claros correpondem a magnetita e ilmenita.

Figura V.5. Diagrama de classificação de clinopiroxênio (Morimoto, 1990) das fácies sieníticas, melasienítica, dioriticas/híbridas e dos enclaves monzoníticos.

Figura V.6. Diagrama classificação de clinopiroxênio (Morimoto, 1990) das fácies sieníticas, melasienítica, dioríticas/híbridas e dos enclaves monzoníticos.

Figura V.7. Diagrama catiônico $\left(\mathrm{Mn} \times \mathrm{Mg} \times \mathrm{Fe}^{2 i}\right.$ ) para clinopiroxênio das fácies sieniticas, melasienítica, dioriticas e dos enclaves monzoníticos.

Figura V.8. Diagrama catiônico $\left[\mathrm{Na} \times \mathrm{Mg} \times\left(\mathrm{Fe}^{2+}+\mathrm{Mn}\right)\right]$ para clinopiroxênio das fácies sieníticas, melasienítica, dioníticas e dos enclaves monzoníticos

Figura V.9. Detalhe do diagrama cationico $\left[\mathrm{Na} \times \mathrm{Mg} \times\left(\mathrm{Fe}^{2+}+\mathrm{Mn}\right)\right]$, apresentado na Figura V.8, ilustrando a tendência evolutiva do clinopiroxênio dos sienitos róseo e verde grosso.

Figura V.10. Correlação entre as proporções catiônicas $\left[\left(\mathrm{Ca}+\mathrm{Fe}^{2+}+\mathrm{Mg}+\mathrm{Mn}+\mathrm{Al}\right) \times\right.$ $(\mathrm{Na}+\mathrm{Fe} 3+)]$ para clinopiroxênios das fácies sieniticas e melasienítica. 
Figura V.11. Imagens de elétrons retro-espalhados, em modo composicional, de cristais de clinopiroxênio, ilustrando os perfis analíticos WDS efetuados e o número de análises. A: clinopiroxênio da fácies sienítica rósea média; B: fácies sienítica rósea de granulação grossa, observar zonamento composicional normal, as bordas mostrando maior coeficiente de retroespalhamento por serem mais ricas em Fe; $\mathrm{C}$ : fácies sienítica verde de granulação grossa; $\mathrm{D}$ : fácies dioritica, observar leve zonamento oscilatório

Figura V.12. Diagramas catiônicos $[(\mathrm{Ca}+\mathrm{Na}) \mathrm{B} \times \mathrm{Na} \mathrm{B}]$ para classificação dos anfibólios (Leake et al, 1997) das fácies petrográficas (A) granítica, (B) sieníticas e (C) dioritica/rochas híbridas e enclaves monzoníticos

Figura V.13. Diagramas cationicos $\left[\mathrm{Si} \times \mathrm{Mg} /\left(\mathrm{Mg}+\mathrm{Fe}^{2+1}\right)\right]$ (Leake et al., 1997) para classificação dos anfibólios das fácies petrográficas do Maciço Corupá.

Figura V.14. Correlação entre proporções cationnicas [(Soma-A $\left.+\mathrm{Si}+\mathrm{R}^{2}\right) \mathrm{x}$ $(\mathrm{NaB}+\mathrm{AllV}+\mathrm{Fe} 3+)]$ dos anfibólios das fácies granítica, sieniticas, dioritica/rochas híbridas e enclaves monzoníticos

Figura V.15. Correlação entre proporções catiônicas [Si+Na+K $\times(\mathrm{Na}+\mathrm{K}) / \mathrm{Al}]$ dos anfibólios das fácies granítica e sieníticas.

Figura V.16. Correlaçâo entre proporções catiônicas (Si x Soma-A) em anfíbólios das fácies sieníticas.

Figura V.17. Correlação entre as proporções catiônicas [(Soma$\left.\left.\mathrm{A})+\mathrm{Al}^{\mathrm{V}}+\mathrm{Fe}^{3+}+(0.5)^{*} \mathrm{Ti} \times \mathrm{Al}{ }^{\mathrm{NV}}\right)\right]$ dos anfibólios das fácies dioritica/rochas híbridas e enclaves monzoníticos.

Figura V.18. Correlação entre proporções catiônicas ( $\mathrm{Si}+\mathrm{Na}+\mathrm{K} \times \mathrm{Ca}+\mathrm{Al}{ }^{\mathrm{NV}}$ )] para anfibólios das fácies (A) granítica e sienítica, (B) diorítica/rochas hibridas e enclaves monzoníticos.

Figura V.19. Imagens de elétrons retro-espalhados em modo composicional de cristais de anfibólio e perfis analíticos WDS efetuados e o número de análises em cada perfil. A: fácies granítica típica, observar bordas adicionadas mais ricas em $\mathrm{Fe}$; B: fácies sienítica rósea de granulação grossa, observar núcleo homogêneo, com borda intermediária com fino zonamento recorrente e borda externa relativamente homogênea, algumas inclusões de ilmenita e acessórios; C: fácies sienítica verde de granulação grossa, observa-se núcleo mais homogêneo, borda intermediária com zonamento recorrente e borda externa mais homogênea e clara, mais rica em Fe; D: fácies híbrida, monzonítica com padrão de zonamento similar ao caso acima...

Figura V.20. Diagrama $\left[\mathrm{Fe} /(\mathrm{Fe}+\mathrm{Mg}) \times \mathrm{Al}^{\mathrm{NV}}\right]$ para classificação da biotita das fácies melasienítica, diorítica/rochas hibridas e enclaves monzoníticos.... 
Figura V.21. Diagrama mostrando a variação entre as proporções catiônicas (Si $x$ Soma-X) da biotita das fácies melasienitica, diorítica/rochas hibridas e enclaves monzoníticos.

Figura V.22. Diagrama mostrando correlação entre as proporções catiônicas $\left[(\mathrm{Fe}+\mathrm{Mg}+\mathrm{Mn})^{Y} \times \mathrm{Ti}\right]$ para biotita das fácies melasienítica, diorítica/rochas híbridas e enclaves monzoníticos

Figura V.23. Diagrama mostrando a correlação entre as proporções catiônicas $\left[(\mathrm{Fe}+\mathrm{Mg}+\mathrm{Mn})^{Y} \times \mathrm{Al}^{\mathrm{VI}}\right]$ para biotita das fácies melasienítica, diorítica/rochas híbridas e enclaves monzoníticos.

Figura V.24. Imagens de elétrons retro-espalhados, em modo composicional, para cristais de biotita com localização dos pontos analíticos WDS. A: fácies diorítica, cristal claro irregular corresponde a um mineral opaco (ilmenita ou magnetita), cristais claros alongados correspondem à prenhita. B: cristal em fácies híbrida (enclave monzonítico)

Figura V.25. (A): Diagrama ternário An-Ab-Or ilustrando a variação composicional, em proporções moleculares, de cristal de plagioclásio da fácies diorítica (imagem exibida em $B$ ); (B): imagem de elétrons retro-espalhados em modo composicional do cristal de plagioclásio, mostrando perfil analítico WDS efetuado e o número de análises, observar zonamento composicional núcleo-borda normal, simples; (C): perfil composicional ilustrando a variação das moléculas de $\mathrm{An}, \mathrm{Ab}$ e Or.

Figura V.26. Diagrama ternário An-Ab-Or (em proporçôes moleculares) ilustrando as estimativas das composições originais obtidas para feldspato alcalino das rochas sieníticas e graniticas. As curvas cotéticas para 800,900 e 1000 oC $(\mathrm{PW}=1 \mathrm{Kbar})$ encontram-se inseridas no diagrama

Figura VI.1. Diagramas binários de variação de tipo Harker para fácies granítica, sieníticas, melasieníticas, diorítica/rochas híbridas e enclave monzonítico. Os dados obtidos por Kaul (1997) e Kaul \& Cordani (2000) para os elementos maiores e menores estão plotados nos diagramas com os dados obtidos para o presente trabalho

Figura VI.2. Diagrama binário de variação $\mathrm{SiO}_{2}$ vs parâmetro mg\#

Figura VI.3. Diagramas binários de variação entre $\mathrm{CaO}, \mathrm{Fe}_{2} \mathrm{O}_{3}, \mathrm{TiO}_{2}, \mathrm{MgO}$ vs $\mathrm{Al}_{2} \mathrm{O}_{3}$ e $\mathrm{MgO}$ vs $\mathrm{CaO}$

Figura VI.4. Diagrama ternário, A-F-M (Irvine \& Baragar, 1971), para as fácies granítica, sieníticas, melasienítica, diorítica/rochas híbridas e enclave monzonítico. 
Figura VI.5. Diagrama binário de variação $\left(\mathrm{SiO}_{2}\right.$ vs $\left.\mathrm{Na}_{2} \mathrm{O}+\mathrm{K}_{2} \mathrm{O}\right)$ discriminante de rochas alcalinas e subalcalinas (Irvine \& Baragar, 1971), para as fácies granítica, sieníticas, melasienítica, dioritica/rochas híbridas e enclave monzonítico

Figura VI.6. Diagrama binário de variação (parâmetros $\mathrm{A} / \mathrm{CNK}$ vs $\mathrm{A} / \mathrm{NK}$ ) discriminante de rochas peralcalinas, metaluminas e peraluminosas (Maniar \& Piccoli, 1989) para as fácies granítica, sieníticas, melasienítica, diorítica/rochas híbridas e enclave monzonítico

Figura VI.7. Diagrama ternário, Qz-Ab-Or (normativos), para as fäcies granítica e sieníticas. As curvas de pressão para 1,2,5 e $10 \mathrm{Kbar}$ encontram-se inseridas no diagrama (ver Tuttle \& Bowen, 1958; Johannes \& Holtz, 1996)

Figura V1.8. Diagrama ternário, An-Ab-Or (normativos), para as fácies granítica e sieníticas. As curvas de pressão para 2 Kbar e atividade de água (a $a_{120}$ ) a 0,1 e 1,0 encontram-se inseridas no diagrama (ver Nekvasil, 1990)

Figura VI.9. Diagramas binários de variação $\left(\mathrm{SiO}_{2}\right.$ vs elementos traços) para as fácies granítica, sieníticas, melasienítica, diorítica/rochas híbridas e enclave monzonítico.

Figura V1.10. Diagramas binários de variação entre elementos traços para as fácies granítica, sieníticas, melasienítica, dioníica/rochas híbridas e enclave monzonítico.

Figura VI.11. Diagrama binários de variação $\left(\mathrm{TiO}_{2}\right.$ vs $\left.\mathrm{Zr}\right)$ para as fácies granítica, sieníticas, melasienítica, dioritica/rochas hibridas e enclave monzonítico.

Figura VI.12. Diagrama binário de variação $(\mathrm{Zr}+\mathrm{Nb}+\mathrm{Ce}+\mathrm{Y}$ vs $\mathrm{IA})$ para as fácies granitica, sieníticas e melasienítica. Os campos discriminantes entre os granitos de Tipo I,S e $\mathrm{M}$ e de Tipo-A encontram-se indicados no diagrama (Whalen et al., 1987).

Figura VI.13. Diagrama binário de variaçâo $(\mathrm{Y}+\mathrm{Nb}$ vs $\mathrm{Rb}$ ) para as fácies granítica, sieníticas, melasienitica, diorítica/rochas híbridas e enclave monzonítico. Os campos discriminantes entre granitos de ambientes Sin-colisionais, Intraplaca, de Arcos Vulcânicos e Orogênicos encontram-se indicados no diagrama (Pearce et al., 1984). 
Figura VI.14. Diagrama binário de variação ( $\mathrm{Y}$ vs $\mathrm{Nb}$ ) para as fácies granítica, sieníticas, melasienítica, dioritica/rochas híbridas e enclave monzonítico. Os campos discriminantes entre granitos de ambientes Sin-colisionais, Intraplaca, de Arcos Vulcânicos e Orogênicos encontram-se indicados no diagrama (Pearce et al., 1984),...

Figura VI.15. Diagrama ternário de variação (Nb-Y-Ce) para as fácies granítica, sieníticas, melasienitica, diorítica/rochas híbridas e enclave monzonítico. Os campos discriminantes para granitos de Tipo-A, segundo Eby (1992) estão indicados no diagrama

\section{ÍNDICE DE FOTOGRAFIAS}

Foto MI.1. Panorama do flanco leste do Maciço Corupá, destacando em primeiro plano a densa vegetação, a cobertura coluvionar em segundo plano e, principalmente, o relevo acidentado da área estudada. ...

Foto III.2. Panorama da porção sudeste do maciço, ilustrando em segundo plano a densa vegetação, o relevo muito acidentado e uma das várias quedas de água da rede de drenagem da Serra do Boi.

Foto M.3. Afloramentos típicos das variedades sieníticas de granulação grossa, constituídos por matacões, a maioria deles rolados, explorados clandestinamente por moradores locais

Foto IV.1. Bloco de sienito róseo de granulação grossa ilustrando bandamento de tipo "schilieren", com bandas mais ricas em minerais máficos discordantes des bandas sieníticas róseas. Proximidades do afloramento Co-34.

Foto IV.2. Sienito róseo e granulação grossa mostrando pequenos "schilierens" máficos irregulares (proximidades do afloramento $\mathrm{Co}-32$ ).

Foto IV.3. Dique decimétrico de sienito róseo de granulação fina cortando a fácies sienítica rósea de granulação grossa (afloramento Co-40).

Foto IV.4. Contato irregular entre fácies sienítica rósea de granulação média e rocha dioritica, sugestivo de certa contemporaneidade de colocação (afloramento Co-49)

Foto IV.5. Contato tectônico entre variedade sienítica muito alterada e meta-siltito da bacia vulcano-sedimentar de Campo Alegre. Borda Oeste do maciço, afloramento $\mathrm{Co}-28$

Foto IV.6. Detalhe da textura da fácies granitica de granulação média, destacando cristais de quartzo xenomórficos intersticiais. 
Foto IV.7. Granito de granulação média, com criststais de feldspato alcalino de coloraçào rosa um pouco mais intensa

Foto IV.8. Sienito róseo grosso, destacado grande cristal de feldspato alcalino (indicado pelo circulo) e minerais máficos agregados e isolados (indicados pelas setas)

Foto IV.9. Sienito róseo grosso com IC aproximadamente $15 \ldots \ldots \ldots \ldots \ldots \ldots \ldots \ldots \ldots$

Foto IV.10. Sienito róseo grosso com IC aproximadamente $5 \ldots \ldots \ldots \ldots \ldots \ldots \ldots \ldots$

Foto IV.11. Sienito róseo médio, exibindo feldspato alcalino com intensa coloração vermelha.

Foto IV.12. Detalhe do sienito róseo médio.

Foto IV.13. Sienito róseo fino, onde observamse glomérulos máficos (indicados pelas setas)

Foto IV.14. Sienito róseo fino com os minerais máficos ocorrendo isoladamente....

Foto IV.15. Sienito verde grosso, destacando glomérulos máficos (indicados pelos circulos)

Foto IV.16. Sienito verde grosso, destacando cristal isolado de clinopiroxênio.

Foto IV.17. Sienito verde médio equigranular.

Foto IV.18. Textura do diorito médio

Foto IV.19. Diorito de granulação média.

Foto IV.20. Monzodiorito de granulação fina.

Foto IV.21. Detalhe do contato entre rocha monzodiorítica e o sienito róseo médio 


\section{ÍNDICE DE FOTOMICROGRAFIAS}

Fotomicrografia IV.1. Crsital subidiomórfico de anfibólio intersticial a feldspato alcalino com zonas cálcio-sódicas (mais escuras) a sódicas (com tons de azul escuro), com bordas esternas de anfibólio sódico em parte serrilhadas. Em branco albita tardia.

Fotomicrografia IV.2. Cristal idiomórfico de anfibólio ilustrando zonamento composicional normal de anfibólios cálcio-sódicos a sódicos, com núcleos em marrom mais escuro e bordas em marrom claro.

Fotomicrografia IV.3. Anfibólio cálcio-sódico com inclusão subidiomórfica de cristal de chevkinita (avermelhada).

Fotomicrografia IV.4. Cristal de anfibólio cálcio-sódico com zonamento composicional da borda superior até a borda inferior.

Fotomicrografia IV.5. Agregados de minerais máficos tardios em fácies sienítica rósea grossa, intersticiais aos minerais máficos e félsicos primários. Observar zonas escuras constituídas por filossilicatos e argilo-minerais contendo agregados aciculares de anfibólio actinolítico tardio

Fotomicrografia IV.6. Cristal idiomórfico de anfibólio com zonamento normal de núcleo cálcico para bordas cálcico-sódicas, contendo inclusão idiomórfica de chevkinita em laranja

Fotomicrografia IV.7. Cristal subidiomórfico de anfibólio mostando zonamento composicional de cálcico (centro, com cor marron-esverdeada) a cálcico-sódico (borda, com cor verde-azulada) em fácies sienito verde médio. Observar inclusão de apatita ou zircão no núcleo do grão. Perto da borda inferior, cristal corroído de clinopiroxênio em marrom.

Fotomicrografia IV.8. Cristal subidiomórfico de anfibólio cálcico homogêneo em contato com plagioclásio, ilmenita (à direita) e magnetita (à esquerda), parcialmente incluindo apatita idiomórfica. Observar restos corroídos de piroxênio

Fotomicrografia IV.9. Cristal de anfibólio cálcico com leve zonamento composicional. Observar cristal de fino cristal biotita na borda à esquerda do grão de anfibólio

Fotomicrografia IV.10. Cristal de anfibólio subidiomórfico com zonamento composicional de cálcico (marron-clara) para cálcico-sódico (tonalidades de verde). Observar inclusão idiomórfica de chevkinita em laranja médio a suave halo pleocróico 
Fotomicrografia IV.11. Clinopiroxênio Ca (núcleo, rosado) a Cama (bordas, verde-escuras). Observar cristais intersticiais de anfibólio à direita, além de inclusão de finíssimos cristais de ilmenita.

Fotomicrografia IV.12. Clinopiroxênio $\mathrm{Ca}$ (núcleo, róseo) a $\mathrm{Ca}-\mathrm{Na}$ (bordas, verde -escuras).

Fotomicrografia IV.13. Cristal de clinopiroxênio com pleocroísmo incipiente e bordas esverdeadas. Notar inclusão de pequenos cristais de zircão e ilmenita.

Fotomicrografia IV.14. Megacristal de clinopiroxênio Ca (regiões do núcleo e intermediárias, tonalidade rosa clara) a $\mathrm{Ca}-\mathrm{Na}$ (bordas verde-escuras) subidiomórfico, apresentando borda parcialmente serrilhada....

Fotomicrografia IV.15. Detalhe de minerais opacos inclusos ao longo dos planos de partição do clinopiroxênio

Fotomicrografia IV.16. Imagem de um megacristal zonado de clinopiroxênio, com inclusão de apatita.

Fotomicrografia IV.17. Clinopiroxênio Ca, apresentando pleocrósmo insipiente. Observar cristais de apatita inclusos, além de magnetita e ilmenita (manteada por biotita) em contato.

Fotomicrografia IV.18. Clinopiroxênio Ca, apresentando pleocrósmo incipiente e cristais de magnetita como inclusão e em contato.

Fotomicrografia IV.19. Clinopiroxênio com bordas de aspecto corródo e pleocrósmo incipiente. Fácies diorito médio, amostra Co-50B. Polarizadores cruzados, sem filtro, lado maior da imagem $2,5 \mathrm{~mm}$

Fotomicrografia IV.20. Biotita sendo substituida, ao longo de seus planos de clivagem, por cristais de prehnita, contendo também inclusões de cristais de magnetita e apatita inclusos.

Fotomicrografia IV.21. Biotita de coloração verde praticamente substituída por cristais de prehnita.

Fotomicrografia IV.22. Biotita sendo substituida, ao longo de seus planos de clivagem, por cristais de prehnita. Cristal médio de magnetita incluso.

Fotomicrografia IV.23. Biotita subidiomórfica em contato com pseudomorfo de anfibólio em sua borda esquerda.

Fotomicrografia IV.24. Feldspato alcalino (aspecto sujo) com albita geminada em sua borda. A esquerda da foto cristal de ilmenita. Na parte centro-superior cristal límpido de quartzo e mais à esquerda, cristal de anfibólio intersticial ... 
Fotomicrografia IV.25. Feldspato alcalino com exsoluçâo de albita tipo "chessboard"

Fotomicrografia IV.26. Textura de intercrescimento microgranofirico entre quartzo e feldspato alcalino

Fotomicrografia IV.27. Cristal de feldspato alcalino, contendo núcleo corroído de plagiclásio primário.

Fotomicrografia IV.28. Plagioclásio ripiforme com núcleo bastante alterado, incluindo pequenos cristais de clinopiroxênio.

Fotomicrografia IV.29. Cristais microfaturados de olivina o cristal maior apresenta-se parcialmente substiuído por agregado de minerais secundários

Fotomicrografia IV.30. Olivina microfraturada incluindo cristais de ilmenita e magnetita, além de fina borda de biotita em sua borda na parte inferior

Fotomicrografia IV.31. Detalhe da textura cumulática do melasienito, com cristais "inter-cumulus" de feldspato alaclino (incolor) e cumulato de minerais máficos envolvendo olivivina, clinopiroxênio, ilmenita e magnetita. 


\section{ÍNDICE DE TABELAS}

Tab. IV.1: Resumo das principais características das fácies petrográficos encontrados no Maciço Corupá

Tabela IV.2. Dadus mudais, em \% de volume mincral, de amostras representativas das fácies petrográficas do Maciço Corupá.

Tabela V.1. Análises químicas (WDS) e fórmula estrutural de olivina das rochas do Maciço Corupá.

Tabela V.2. Análises químicas (WDS) e fórmulas estruturais de clinopiroxênio das rochas do Maciço Corupá.

Tabela V.3. Análises químicas (WDS) e fórmulas estruturais de anfibólios das rochas do Maciço Corupá.

Tabela V.4. Análises químicas (WDS) e fórmulas estruturais de biotita das rochas do Maciço Corupá.

Tabela V.5. Análises químicas (WDS) e fórmulas estruturais de plagioclásio das rochas dioríticas do Maciço Corupá.

Tabela V.6. Composição química primária estimada dos feldspatos alcalinos das rochas sieníticas e graníticas do Maciço Corupá.

Tabela VI.1 Análises quimicas, em rocha total, dos elementos maiores, menores (em \% de óxido) e traços (em ppm) das principais fácies petrográficas do Maciço Corupá.

Tabela VI.2 Análises normativas (CIPW) das principais fácies petrográficas do Maciço Corupá 


\section{RESUMO}

O Maciço Corupá aflora na região N-NE do estado de Santa Catarina, por uma área aproximada de $50 \mathrm{~km}^{2}$, com forma semi-anelar, intrusivo em rochas gnáissico-granulíticas da Microplaca Luis Alves, no extremo meridional da Província Serra do Mar constituída de sienitos e granitos neoproterozóicos de Tipo-A.

O maciço é constituído de rochas sieníticas, que compreendem seis fácies petrográficas, rochas graníticas, dioríticas, híbridas, além de enclaves monzoníticos associados a variedade de sienito róseo de granulação média.

A variedade de sienito de coloração verde apresenta granulação que varia de média a grossa, já o sienito de coloração rósea apresenta granulações finas, médias e grossas. O álcalifeldspato sienito supersaturado, hipersolvus, de coloração verde $(5<\mathrm{IC}<15)$, é constituido por clinopiroxênio hedenbergítico, anfibólio cálcico a cálciomsódico, olivina faialitica. As variedades de coloração rósea $(5<\mathrm{IC}<15)$ são predominantes no maciço, e são compostas por clinopiroxênio hedenbergítico a aegirina augítico e anfíbólio cálcico a cálcio-sódico. Em todas as variedades sieníticas, os acessórios típicos incluem chevkinita, ilmenita, apatita e zircão.

$\mathrm{O}$ álcali-feldspato melasienito $(\mathrm{IC}>50)$ é saturado, com clinopiroxênio hedenbergítico, olivina ferro-hortonolitica, biotita, ilmenita, magnetita, apatita e zircăo.

Álcali-feldspato granitos hipersolvus $(\mathrm{IC} \sim 5)$ são subordinados, e afloram principalmente nas áreas centrais do anel sienitico. Apresentam, entre os minerais máficos, anfibólio cálciosódico a sódico, chevkinita, zircão, apatita e fluorita. Rochas dioríticas equigranulares de granulação média $(10<\mathrm{IC}<15$, com clinopiroxênio diopsídico, anfibólio cálcico, biotita, magnetita, ilmenita, apatita e zircão) aparecem sob a forma de diques sin-plutônicos de dimensões métricas e em pequenos corpos irregulares. Enclaves híbridos de composições monzodioríticas a monzoníticas ocorrem associados aos sienitos róseos de granulação média.

Os álcali-feldspato sienitos e melasienitos são metaluminosos (tipos mais máficos, 0,61 $<\mathrm{A} / \mathrm{CNK}<0,88$ e $1,02<\mathrm{A} / \mathrm{NK}<1,13,0,16<\mathrm{mg} \sharp<0,37$; os melasienitos chegam a apresentar 
$20 \%$ em peso de $\mathrm{Fe}_{2} \mathrm{O}_{3}$ ) a peralcalinos (tipos mais félsicos, $0,82<\mathrm{A} / \mathrm{CNK}<0,84$ e $\mathrm{A} / \mathrm{NK}=0,96$, $0,10<\mathrm{mg} \#<0,13)$, enquanto os álcali-feldspato granitos são tipicamente peralcalinos $(\hat{A} / \mathrm{CNK}=$ $0,86 \mathrm{e} A / \mathrm{NK}=0,94, \mathrm{mg} \#=0,08)$. As rochas dioríticas são metaluminosas, com $0,50<\mathrm{mg} \#<0,55$ $\left(11,60 \%<\mathrm{Fe}_{2} \mathrm{O}_{3}<13,50 \%, 6,10 \%<\mathrm{Na}_{2} \mathrm{O}+\mathrm{K}_{2} \mathrm{O}<7,80 \%\right.$ e $\left.1,85 \%<\mathrm{K}_{2} \mathrm{O}<2,80 \%\right)$. Os enclaves híbridos, principalmente os de composição mozonítica, apresentam valores intermediários entre os dioritos e os sienitos.

As relações petrográficas e o quimismo de rochas e minerais sugerem que as rochas sieníticas estão relacionadas por processos simples de cristalização fracionada em condições de oxidação inferiores as do tampão QFM, a partir de um magma parental sienítico, através principalmente do fracionamento de fases minerais máficas (acessórios, olivina faialita, clionopiroxênio hedenbergítico e, por último, anfíbólio cálcio-sódico), cujos liquidus residuais finais estariam cristalizariam discretamente como álcali-feldspato granitos peralcalinos.

As rochas dioríticas constituem uma associação contemporânea, contrastada, não fazendo parte da mesma linhagem evolutiva das rochas sieníticas e graníticas. Estas rocha foram originadas a partir de magmas basico-intermediários cristalizados sob condições mais oxidantes com magnetita estável. Estudos mais recentes em outros maciços da provincia mostram que este magmatismo bimodal é comum e indicam fontes contrastadas do manto e da crosta continental na sua gênese. 


\begin{abstract}
The Corupá Massif outcrops in the N-NE region of Santa Catarina State, occupying a semi-ring shaped area of $50 \mathrm{Km}^{2}$, being intrusive in gneissic-granulitic rocks of the Luis Alves microplate, in the southernmost end of the Serra do Mar Province, which is made up by neoproterozoic A-Type syenites and granites.
\end{abstract}

The massif is constituted by syenitic rocks, that comprehend six petrographic facies, as well as granitic, dioritic and hybrid rocks, besides monzodioritic to monzonitic enclaves associated to the rosy syenite of medium granulation.

The green-coloured syenite presents granulation varying from medium to coarse-grained, whilst the rosymcoloured syenite is fine to coarsed-grained. The supersaturated, hypersolvus, green-coloured alkali-feldspar syenite $(5<\mathrm{IC}<15)$ is constituted by hedenbergitic clinopyroxene, calcic to sodic-calcic amphibole and fayalitic olivine. The rosy-coloured varieties $(5<\mathrm{lC}<15)$ are predominant in the massif, and are composed by hedenbergitic to aegirine-augitic clinopyroxene and calcic to sodic-calcic amphibole. In all syenitic varieties the typical accessory minerals include chevkinite, ilmenite, apatite and zircon.

The alkali-feldspar melasyenite (IC $>50)$ is saturated, with hedenbergitic clinopyroxene, ferrohortonolitic olivine, biotite, ilmenite, magnetite, apatite and zircon.

Hypersolvus alkali-feldspar granites $(\mathrm{IC} \sim 5)$ are subordinated, and they appear mainly in the central areas of the syenitic ring. They present, among the mafic minerals, sodic-calcic to sodic amphibole, chevkinite, zircon, apatite and fluorite. Dioritic equigranular rocks of medium granulation $(10<\mathrm{IC}<15$, with diopsidic clinopyroxene, calcic amphibole, biotite, magnetite, ilmenite, apatite and zircon appear as syn-plutonic dykes of metric dimensions and as small irregular bodies. Hybrid enclaves of monzodioritic to monzonitic compositions occur associated with the rosy syenites of medium granulation.

The syenitic rocks are typically metaluminous. The melasyenite presents $\mathrm{A} / \mathrm{CNK}=0.60$

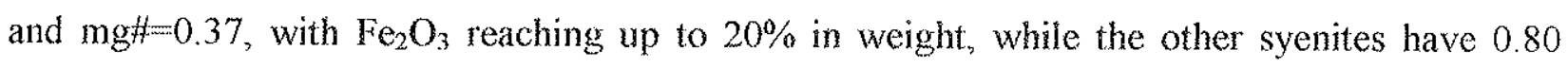


$<\mathrm{A} / \mathrm{CNK}<0.90, \quad 0.96<\mathrm{A} / \mathrm{NK}<1.09$ and $0.10<\mathrm{mgH}<0.29 \quad\left(5.20 \%<\mathrm{Fe}_{2} \mathrm{O}_{3}<6.25 \%\right)$ and $10.80 \%<\mathrm{Na} 2 \mathrm{O}+\mathrm{K} 2 \mathrm{O}<11.70 \%$. The alkali-feldspar granites are, on the other hand, peralcaline $(\mathrm{A} / \mathrm{CNK}=0.86$ and $\mathrm{A} / \mathrm{NK} \quad<0.94)$, with $\mathrm{mg} \#=0.08 \quad\left(2.80 \%<\mathrm{Fe}_{2} \mathrm{O}_{3} \quad<3.00 \%\right)$ and $9.00 \%<\mathrm{Na}_{2} \mathrm{O}+\mathrm{K}_{2} \mathrm{O}<9.70 \%$. The dioritic rocks are metaluminous, with $0.50<\mathrm{mg \#}<0.55$ $\left(11.60 \%<\mathrm{Fe}_{2} \mathrm{O}_{3}<13.50 \%\right)$ and $6.10 \%<\mathrm{Na}_{2} \mathrm{O}+\mathrm{K}_{2} \mathrm{O}<7.80 \%\left(1.85 \%<\mathrm{K}_{2} \mathrm{O}<2.80 \%\right)$, while the hybrid enclaves present values intermediate between those of the syenites and diorites.

The petrographic relationships and the chemical characteristics of these rocks and minerals suggest that the syenitic rocks were brought about by a simple processes of fractional crystallization under oxidation conditions below the QFM buffer, starting from a parental syenitic magma, mainly trough the fractionation of the mafic mineral phases (accessories, fayalite, calcic-sodic clionopyroxene and, finally, sodic-calcic amphibole), with the final residues crystallizing as discreet alkali-feldspar peralcaline granites.

The dioritic rocks constitute a contemporaneous, but very contrasted association, originated initially from basic-intermediate magmas under more oxidizing conditions, with stable magnetite. Studies in other massifs show that this bimodal magmatism is common in the Serra do Mar Province and it indicates contrasted mantle and contintal crust sources in their genesis. 


\section{Capítulo I}

Introdução 


\subsection{Introdução}

A geologia e petrologia das associações graniticas Tipo-A têm merecido atenção especial dos estudiosos das rochas graníticas nos últimos anos. Desde a definição original de Loiselle \& Wones (1979), o debate envolvendo os mais diversos aspectos de ocorrência e petrogênese destas rochas tem se intensificado, ao extremo de serem denominadas de TipoAmbiguo por Hogan et al. (1992).

Assim, embora esteja claro que diversas características comuns apontem similaridades genéticas e evolutivas, está também claro que estes granitos ocorrem em ambientes tectônicos variados (e.g., anorogênicos vs. pós-colisionais, Pitcher, 1993) e que compõem associações petrográficas contrastadas, uma que inclui rochas metaluminosas a peralcalinas (a associacão alcalina de granitos de Tipo-A), outra formada por rochas metaluminosas a peraluminosas (a associação aluminosa de granitos de Tipo-A) (e.g., Lameyre \& Bowden, 1982; Anderson, 1983 ; Vlach et al., 1990; King et al., 1997; Bonin et al., 1998;).

Nas regiões sudeste e sul do Brasil ocorrem duas importantes províncias graníticas de Tipo-A neoproterozóicas (ca. 600-570 Ma). A primeira, denominada Província Itu é constituída essencialmente de variedades da associação aluminosa (Vlach et al., 1996; 1990; Wernick, 1998), enquanto que na segunda, a Província Serra do Mar (ou Suíte Serra do Mar; Kaul, 1997) (Fig.l.l) (Vlach et al., 1996), afloram tanto rochas da associação aluminosa quanto da associação alcalina.

A coexistência dos termos aluminosos e peralcalinos nesta última, tornam-a particularmente interessante para estudos petrológicos comparativos, os quais têm sido um dos objetos de pesquisa do grupo de estudo de granitóides do Instituto de Geociências da Universidade de São Paulo (e.g., Gualda, 2001). Esta provincia é constituída por mais de uma dezena de maciços graníticos e sieníticos para os quais já se encontra informações básicas essenciais em quantidade adequada, permitindo um estudo mais aprofundado (Kaul, 1984, 1997; Siga Jr., 1995; Kaul \& Cordani, 2000, entre outros). Neste contexto, um dos maciços mais importantes é o denominado "Granito Corupá" (SC) (Albuquerque et al., 1971) em que afloram sienitos e álcali-feldspato granitos exclusivos da associação alcalina. 


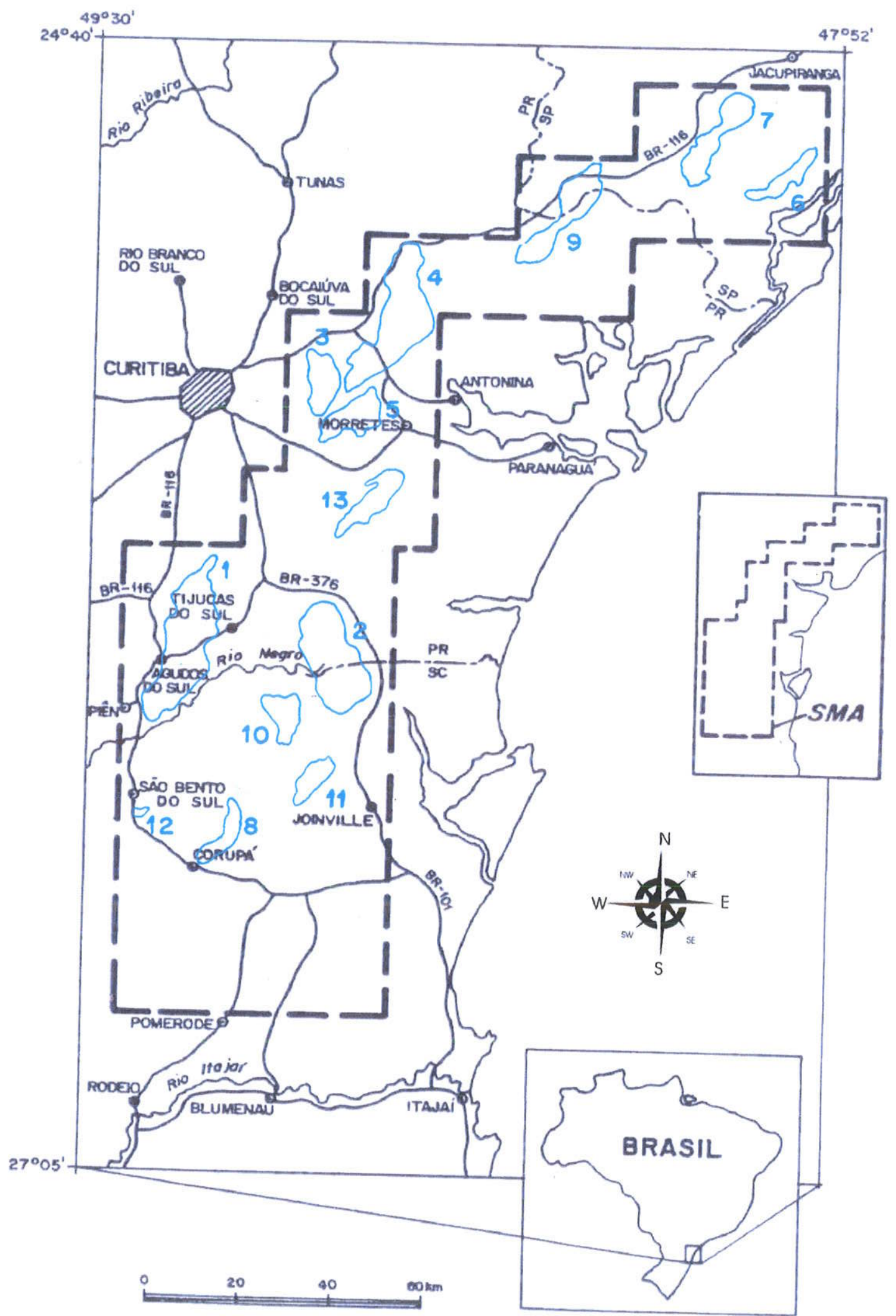

Fig. I.1: Mapa indicando a localização da Suite Serra do Mar e as principais vias de acesso. Os contornos aproximados dos maciços itrusivos são destacados em azul. 1 - Granito Agudos; 2 - Granito Morro Redondo; 3 Granito Anhangava; 4 - Granitos da Graciosa; 5 - Granito Marombi; 6 - Granito Mandira; 7 - Granito Guarau; 8 Granito Corupa; 9 - Granito Alto Turvo; 10 - Granito Dona Francisca; 11 - Granito Pirai; 12 - Granito Serra Alta; 13 - Granito Serra da Igreja. . (Modificado de Kaul, 1997) 
O objetivo deste trabalho é fornecer uma caracterização petrográfica, mineralógica e geoquímica mais detalhada para o Maciço Corupá de modo a adicionar novas informações que, ao lado dos dados obtidos para os Maciços da Graciosa e Anhangava (Gualda, 2001), embasem trabalhos petrológicos futuros e, em parte, já em andamento.

Neste trabalho será utilizada a denominação Maciço Corupá, ao invés do termo Granito Corupá, ainda empregado atualmentè (e.g., Kaul, 1984, 1997; Siga Jr. et al., 1994), uma vez que os resultados disponíveis, aliados aos agora obtidos, indicam que rochas graníticas são bem subordinadas em relação às rochas sieníticas. 


\subsection{Aspectos gerais da área de estudo}

O Maciço Corupá aflora na região NNE do Estado de Santa Catarina, no domínio dos municípios de Corupá, Jaraguá do Sul, Schroeder e São Bento do Sul . Em relação às cartas topográficas 1:50.000 do Instituto Brasileiro de Geografia e Estatística, encontra-se inserido na Folha Jaraguá do Sul (SG-22-Z-B-I-4; MI-2869/4). Os principais acessos às áreas de afloramento partem das localidades de Corupá e Santa Luzia (Fig. I.2).

A área ocupada pelo maciço é de aproximadamente $50 \mathrm{~km}^{2}$ e apresenta-se de forma semi-anelar alongada N-S com convexidade voltada para Leste. Os pontos culminantes apresentam altitudes da ordem de $1200 \mathrm{~m}$.

As áreas de afloramento das rochas sieníticas e graníticas são topograficamente elevadas, formando a Serra do Boi com vertentes acentuadas $(>75 \%)$, o que resulta em grandes quedas nas drenagens e extensa cobertura coluvionar nas zonas de borda do maciço.

O clima da região é mesotérmico brando a médio, bastante úmido e sem períodos marcados de seca. A vegetação é constituída por Mata Atlântica densa, com mais de $80 \%$ de preservação. Tais características dificultam em muito os trabalhos básicos de campo, prejudicando o acesso a diversas áreas, a determinação mais precisa de contatos geológicos internos e externos, bem como a coleta de amostras sãs in situ. 


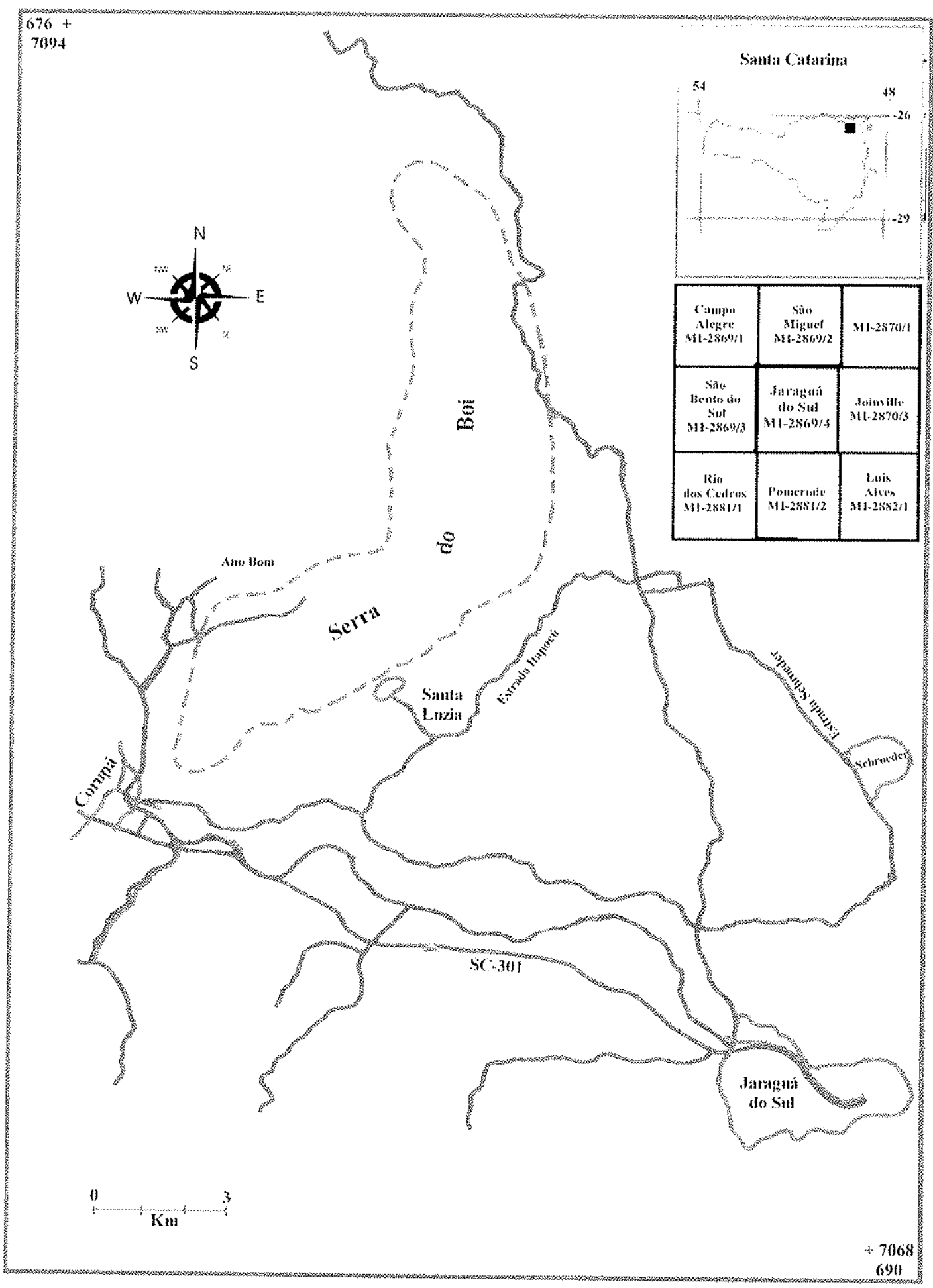

Figura 1.2: Principais vias de acesso (linhas cheias) ao Maciço Corupá (contorno tracejado), localização da área de estudo no Estado de Santa Catarina e articulação da Folha Jaraguá do Sul. (Modificado de Oliveira, 1997). 


\subsection{Plano de apresentação da dissertação}

Após uma breve síntese do estado de conhecimento das associações graníticas de TipoA na Província Serra do Mar e no Maciço Corupá (Capítulo II), a metodologia empregada neste trabalho é apresentada no Capítulo III.

O Capítulo IV reúne algumas informações geológicas gerais e apresenta as fácies petrográficas mais típicas do maciço. Dados texturais e de quimismo mineral são apresentados e discutidos no Capítulo V e a geoquímica em rocha total (elementos maiores, menores e alguns traços) é tratada no Capítulo VI.

Os dados obtidos e as interpretações alcançadas, integrados aos já disponíveis em literatura e conclusões finais são acrescentados no Capítulo VII. 


\section{Capítulo II}

Província Serra do Mar e Maciço Corupá: breve síntese de conhecimentos 


\section{II.1 As associações graníticas de Tipo-A na Província Serra do Mar}

A Província Serra do Mar agrega mais de uma dezena de maciços graníticos e sieníticos neoproterozóicos (Figura l.1, Capítulo I) que distribuem-se ao longo da costa entre os estados de Santa Catarina e São Paulo. Estes maciços estão colocados principalmente em rochas granulíticas arqueanas do Craton Luis Alves e rochas gnáissicas e migmatíticas da denominada Microplaca Curitiba (Kaul, 1984, 1997; Siga Jr. et al., 1993).

Uma extensa revisão das características geológicas, petrográficas, geoquímicas e geocronológicas das rochas graníticas e sieníticas de Tipo-A disponíveis na literatura internacional, além das que afloram na província, é apresentada por Gualda (2001). Algumas informações mais gerais são sintetizadas a seguir.

Os maciços da província têm geometrias variadas, sugestivas ora de colocação controlada por estruturas crustais rúpteis, ora sem um controle estrutural mais evidente. De forma geral, o predomínio de estruturas maciças é compatível com a sua instalação em ambientes sem esforços compressivos relevantes. A associação com bacias vulcano-sedimentares contemporâneas com vulcanismo tipicamente bimodal e a presença de rochas subvulcânicas nos maciços, aliadas a características estruturais e texturais (cavidades miarolíticas, quartzo bipiradidal, rochas felspáticas hipersolvus, etc.) indicam que os maciços se colocaram em níveis crustais relativamente rasos (Góis, 1995; Siga Jr., 1995; Gualda 2001).

De acordo com Siga Jr. et al. (1993) a geração dos magmas nesta província seria a consequiência do rearranjo crustal decorrente do espessamento litosférico quando da colisão entre o Cinturão Granitóide Costeiro e as Microplacas Curitiba e Luis Alves, em ambientes tipicamente pós-colisionais, uma concepção compartilhada por diversos autores na literatura internacional (e.g., Turner et al., 1992; Bonin et al., 1998).

Informações geocronológicas obtidas com as metodologias $\mathrm{Rb} / \mathrm{Sr}$ e $\mathrm{U} / \mathrm{Pb}$ sugerem idades de colocação com intervalos muito amplos, entre 520 e $600 \mathrm{Ma}$ para as rochas intrusivas e entre 500 e 420 Ma para os derrames vulcânicos associados às bacias vulcano-sedimentares (Figura II.I, Siga Jr. et al., 1993). Merece ser ressaltado que diversos destes resultados foram obtidos 
através de isócronas $\mathrm{Rb} / \mathrm{Sr}$, mostrando-se por vezes muito jovens quando comparados com idades mais precisas obtidas por $\mathrm{U} / \mathrm{Pb}$ em zircões. Assim, é de se esperar que futuros refinamentos com a metodologia $\mathrm{Rb} / \mathrm{Sr}$ diminuam tais intervalos, os quais devem se aproximar das determinações U/Pb que tendem a se concentrar entre 600 e 570 Ma (Figura II.1, Siga Jr., 1995).

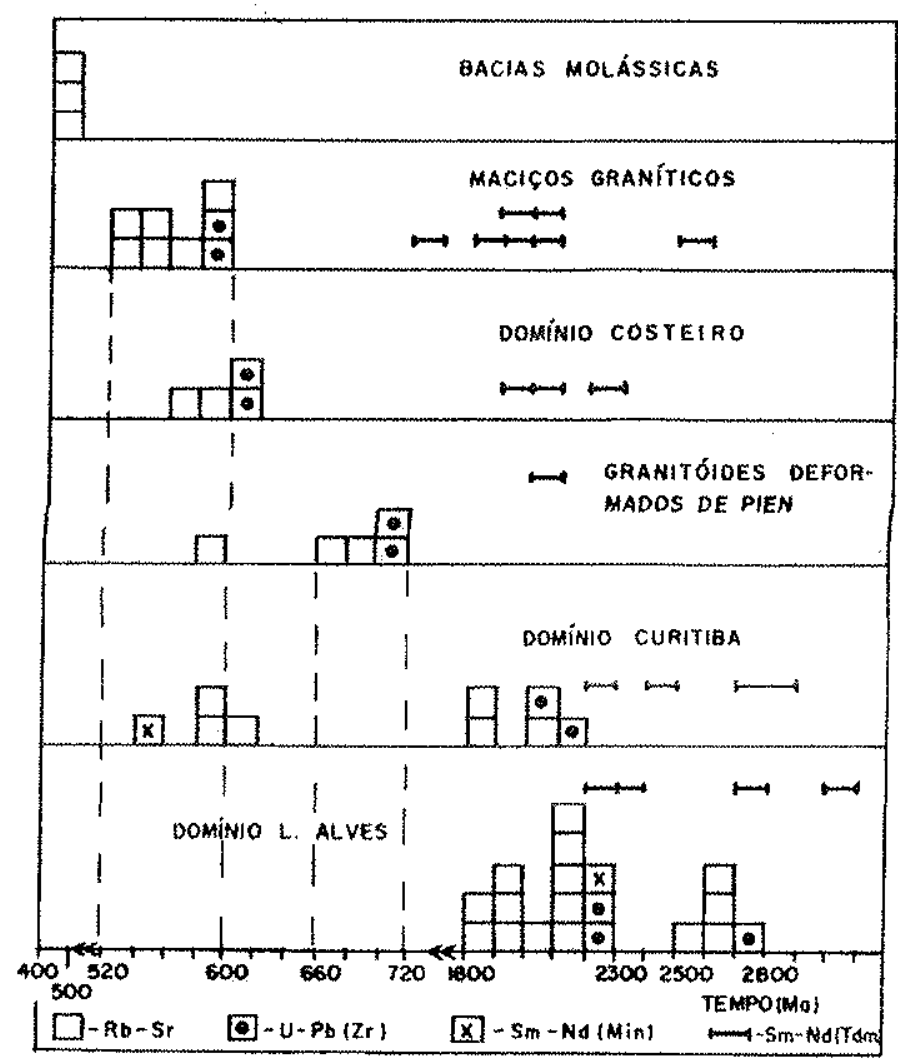

Figura II.1: Quadro geral das idades U-Pb, Rb-Sr e idades modelo TDM (Sm-Nd) obtidas para as rochas graníticas e sieníticas da Província Serra do Mar (segundo quadro de cima para baixo) e de unidades geológicas adjacentes. (Extraido de Siga Jr. et al., 1993).

De forma geral, as rochas graníticas e sieníticas da província podem ser reunidas em duas associações petrográficas distintas (Vlach, 1999; Gualda, 2001). Uma associação alcalina, na concepção de Lameyre \& Bowden (1982), que inclui álcali-feldspato sienitos e granitos tipicamente hipersolvus que gradam de metaluminosos (termos mais máficos) a peralcalinos (termos mais félsicos), outra associação aluminosa (Vlach, 1999) caracterizada por monzo- e sienogranitos subsolvus metaluminosos (termos mais máficos) a moderadamente peraluminosos (termos mais félsicos). 
Rochas grabro-dioríticas são relativamente raras na província. Biotita-hornblenda-quartzo dioritos e monzodioritos e rochas monzoníticas, estes últimos freqüentemente com aspecto híbrido afloram na região dos Granitos da Graciosa (Maack, 1961; Gualda, 2001) e também no Maciço Corupá (Oliveira, 1997). Kaul (1997) descreve núcleos de plagioclásio corroído em feldspato alcalino em algumas rochas sieníticas/monzoníticas da província e interpreta-os como evidência da origem destas rochas pela cristalização fracionada de magmas básicointermediários parentais, mas as observações próprias a serem discutidas na presente dissertação, bem como as evidências demonstradas em Gualda (2001) e Oliveira (1997) são mais compatíveis com a hipótese de coexistência de magmas originalmente contrastados, derivados de fontes independentes, compatíveis com um caráter bimodal também para os maciços intrusivos nesta província.

Dados geoquímicos para as rochas da província foram obtidos e discutidos por Kaul (1997), Kaul \& Cordani (2000) e Gualda (2001). De forma geral, as características geoquímicas são comuns às encontradas na literatura internacional sobre os granitos de tipo-A (e.g., Whalen et al., 1987; Eby, 1990, 1992), destacando-se as concentrações relativamente elevadas de álcalis, elementos terras raras (ETRs) e de alto potencial iônico. De forma geral, as associações alcalina e aluminosa correspodem aos granitos anorogênicos (relacionados à zonas de rift, hotspots ou plumas mantélicas) e pós-colisionais (arcos de ilha e margens continentais), quimicamente distintos por Eby (1992).

Em diagramas elaborados por Whalen et al. (1987) as rochas da Província Serra do Mar classificam-se como granitos de Tipo-A e como Tipo-I altamente fracionados (ver discussão sobre assunto na referência acima); já os diagramas discriminantes de Pearce et al. (1984) caracterizam ambientes tectônicos intra-placa para as rochas da província (Figura II.2). 

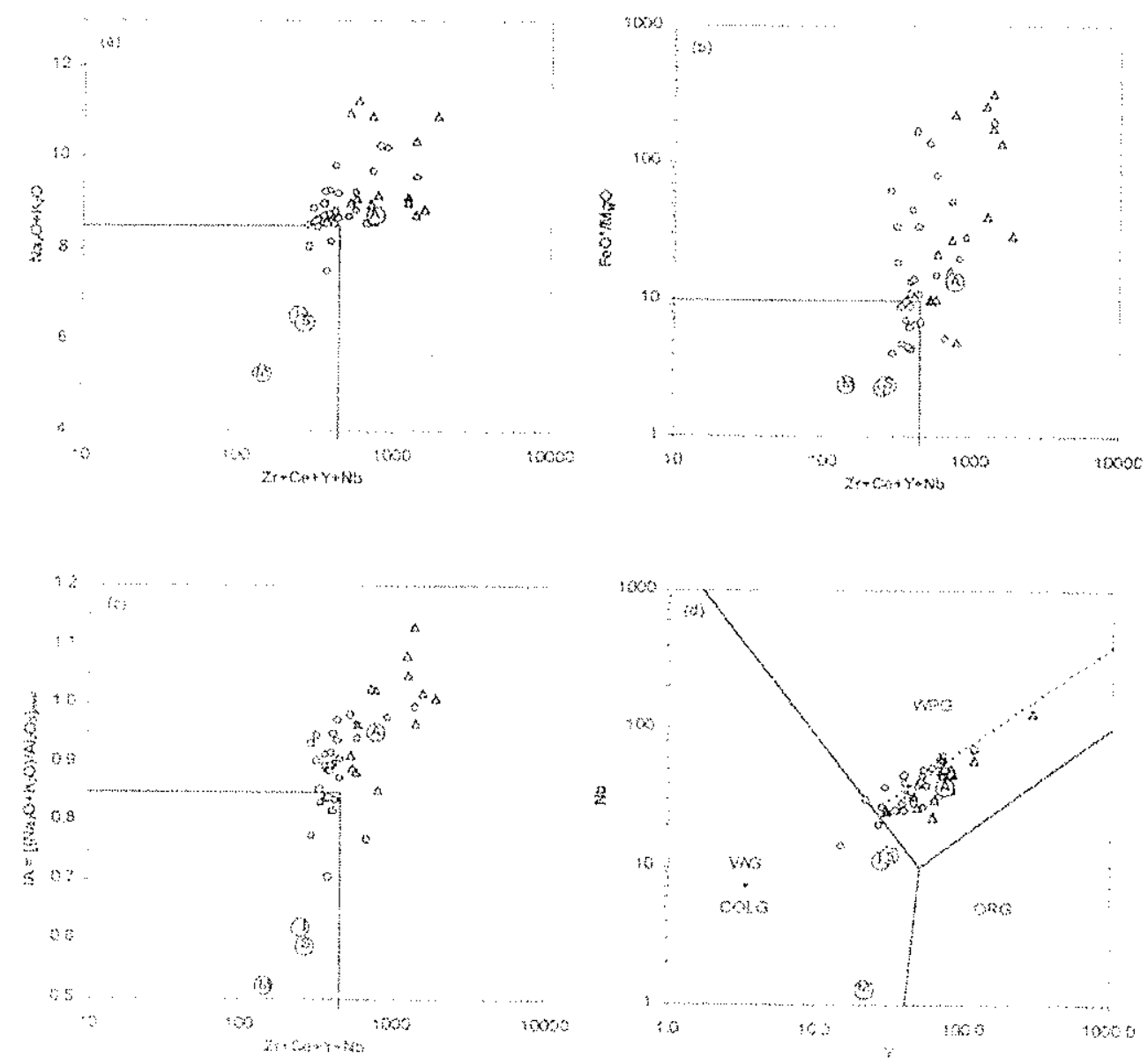

Figura 11.2: Diagramas discriminantes selecionados para as rochas da Provincia Serra do Mar, caracterizando-as granitos de Tipo-A. (Extraído de Gualda, 2001). 


\section{III.2 O Maciço Corupá}

O Maciço Corupá foi mapeado em escala 1:250.000 e estudado pioneiramente por Albuquerque et al. (1971). Denominado na época de "Granito Corupá", foi abordado em vários trabalhos posteriores com destaque para Daitx (1979) que elaborou um mapa mais detalhado em escala 1:50.000. Entretanto, somente após os trabalhos de Kaul (1984, 1997), Siga Jr. (1995), Chiessi et al. (1998), Vlach (1999) e Kaul \& Cordani (2000) o conhecimento de diversos aspectos geológicos, petrográficos, mineralógicos e geocronológicos do maciço avançou significativamente.

O maciço aflora no extremo meridonal da Província Serra do Mar, ocupando uma área aproximada de $50 \mathrm{~km}^{2}$. Apresenta forma semi-anelar, em bumerangue, que estaria, pelo menos em parte, condicionada por zonas de cisalhamento orientadas SW-NE (Kaul, 1997).

As rochas descritas são variedades de álcali-feldspato sienitos e granitos hipersolvus, cuja origem estaria possivelmente associada à evolução da Bacia vulcanosedimentar de Campo Alegre (Daitx, 1979; Kaul, 1997).

As rochas que constituem o maciço são tipicamente da associação alcalina de tipo-A. As rochas correspondem modalmente a álcali-felspato sienitos e álcali-feldspato granitos com estruturas em geral maciças e textura equi- a inequigranular de granulações grossas, médias e finas. Oliveira (1997) descreve enclaves monzoníticos de aspecto híbrido em algumas rochas sieníticas de granulação média.

A mineralogia presente nos álcali-feldspato sienitos inclui, além de feldspato alcalino e quartzo muito subordinado, olivina faialítica, clinopiroxênio, anfíbólios cálcicos e cálcio-sódicos como minerais máticos típicos e chevkinita, zircão e apatita como acessórios característicos. Nas rochas graníticas, anfibólio sódico é o máfico típico e os acessórios são similares. O mineral opaco primário em ambas as rochas é a ilmenita. Nos enclaves monzoníticos são descritos clinopiroxênio, anfibólio cálcico, biotita, ilmenita e magnetita (Kaul, 1997; Oliveira, 1997; Chiessi et al., 1998; Vlach, 1999). 
Dados geoquímicos (elementos maiores, menores e principais elementos traço) de amostras representativas, incluindo algumas análise para os elementos terras raras, para o Maciço Corupá foram apresentados e discutidos por Kaul (1997) e Kaul \& Cordani (2000). Estes autores ressaltam o caráter metaluminoso e peralcalino das rochas sieníticas e graníticas, respectivamente, e sugerem o seu caráter comagmático, relacionando sienitos e granitos por mecanismos de cristalização fracionada simples, a partir de magmas parentais básicointermediários. Neste sentido, os padrões de ETR obtidos refletiriam, em um primeiro estágio, a extração de plagioclásio e após, a evolução dos padrões de muito fracionados nas rochas sieníticas para tipicamente com forma de "gaivota" nas rochas graníticas refletiria a cristalização de fases acessórias ricas em ETR leves. A evolução destes padrões é demostrada por Vlach (1999) como sendo decorrente da cristalização relativamente precoce da chevkinita, um titanossilicato de Fe rico em ETR leves (até $45 \%$ em peso de ETRT).

Diagramas de variação de tipo Harker e envolvendo elementos traços e de padrões de distribuição de ETRs, apresentados por Kaul (1997) são reproduzidos nas Figuras II.3 e II.4, para fins comparativos com os dados geoquímicos obtidos para este trabalho.

Informações geocronológicas de qualidade para o Maciço Corupá foram apresentadas por Siga Jr. et al. (1993) e Siga Jr. (1995). Isócronas Rb/Sr forneceram idades de cristalização de 550 ( \pm 26) Ma para as rochas sieníticas e graníticas, com razões iniciais $\left({ }^{87} \mathrm{Sr}{ }^{86} \mathrm{Sr}\right)_{0}$ de $0,7070( \pm$ 0,0010). Datações mais realistas, pela metodologia $\mathrm{U} / \mathrm{Pb}$ em zircões das rochas graníticas, resultaram em idades mais adequadas de $580( \pm 6) \mathrm{Ma}$. Dados isotópicos $\mathrm{Sm} / \mathrm{Nd}$ indicam idades $\mathrm{T}_{\mathrm{DM}}$ de $1,94 \mathrm{Ga}$ e valores de $\mathrm{eNd}$ de $-18,8$, resultados sugestivos de que magmas parentais foram gerados a partir de fontes com longa residência crustal ou que incluem contribuições significativas de materiais crustais antigos, ou ainda a partir de fontes mantélicas enriquecidas em elementos incompatíveis e de alto potencial iônico, durante o Paleoproterozóico Médio. 

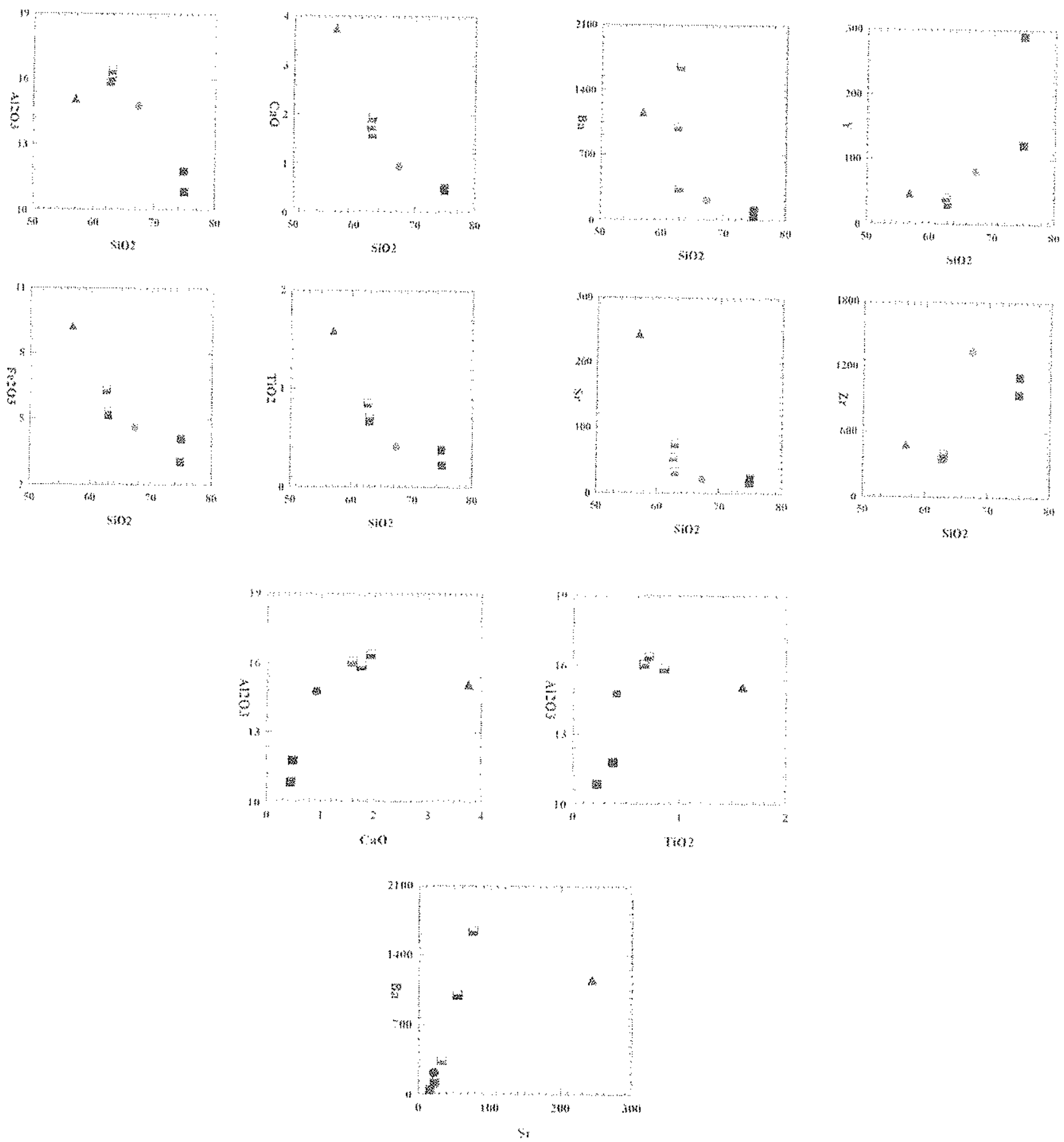

Figura 11.3: Diagramas de variação para elementos maiores menores e traços selecionados das rochas sieniticas e graníticas do Maciço Corupá. Triângulos: sienito fino. Quadrados meio vazados: sienito grosso. Circulos cheios: quartzo sienito. Quadrado cheio: granito. (Extraído de Kaul, 1997). 

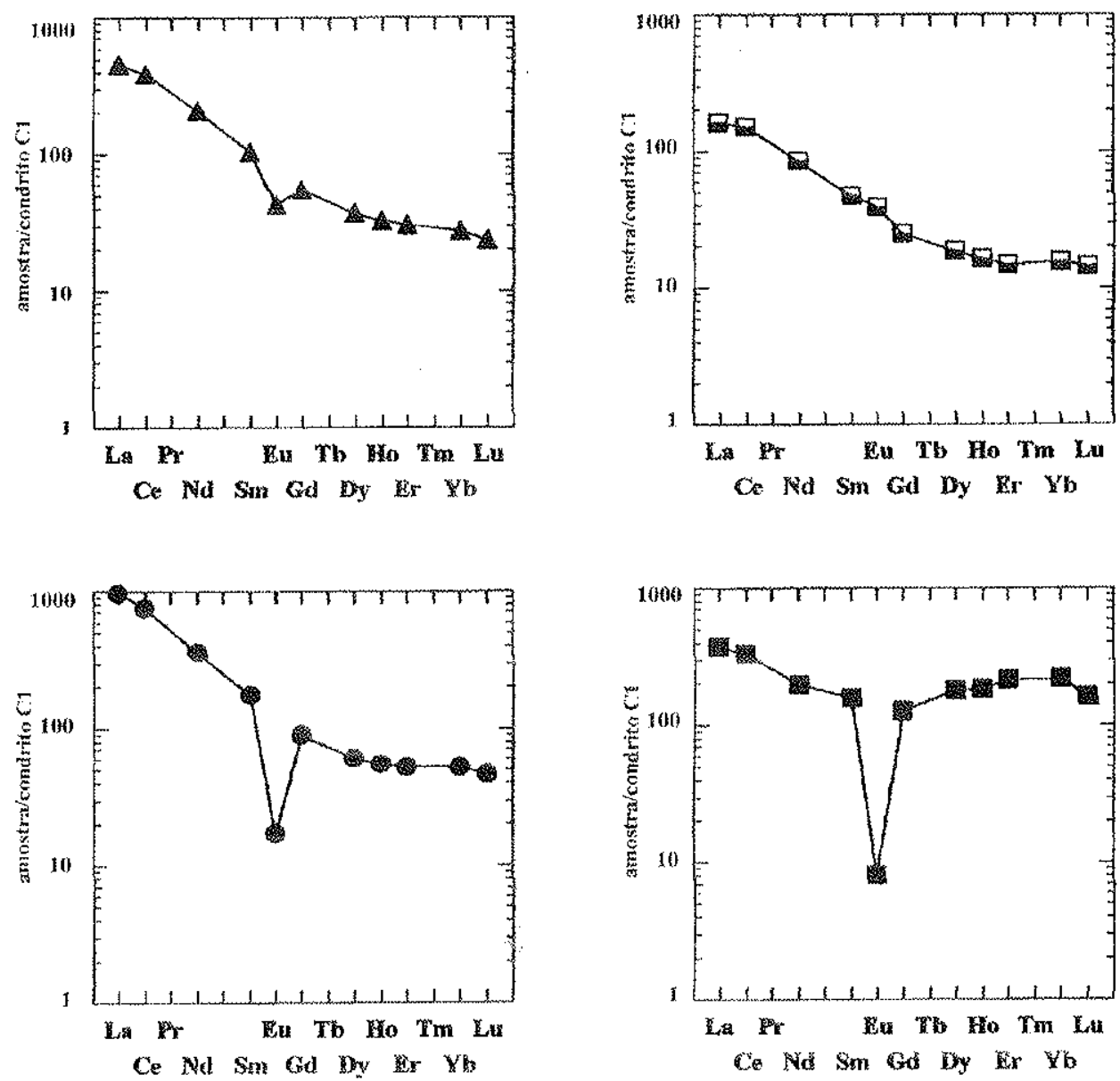

Figura II.4: Diagramas de ETR normalizados aos condritos para as rochas sieniticas e graniticas do Maciço Conupá. Triângulos: sienito fino. Ouadrados meio vazados; sienito grosso. Circulos cheios; quartzo sienito. Quadrado cheio: granito.

(Extraído de Kaul, 1997). 


\section{Capítulo III}

Metodologia 
Após uma etapa inicial de familiarização com a literatura especializada sobre os granitos de Tipo-A em geral e sobre o estudo do conhecimento da Província Serra do Mar e do Maciço Corupá, em particular, a presente dissertação envolveu diversas etapas de campo e laboratório, brevemente descritas a seguir.

\section{III.1 Trabalhos em campo}

Os trabalhos de campo foram realizados em três etapas: Abril e Junho de 2000 e em Janeiro de 2001, em um total de cerca de 25 dias. Estas etapas tiveram como objetivo a identificação e descrição das principais variedades petrográficas presentes, bem como sua distribuição geográfica no Maciço Corupá. A folha topográfica Jaraguá do Sul (SG-22-Z-B-I4/MI-2869/4) em escala 1:50.000 (IBGE, 1981) foi utilizada como base planimétrica.

O acesso às áreas de afloramento do maciço é de forma geral muito difícil. Nas áreas periféricas da Serra do Boi existem vias intermunicipais não pavimentadas e algumas trilhas abertas por moradores da região. As áreas mais internas e de maior altitude, entretanto, apresentam enormes dificuldades de acesso, pois os caminhos são escassos e mal conservados; ademais, a maioria destas são áreas de preservação ambiental e, salvo algumas exceções, os proprietários de terras não autorizaram a realização dos trabalhos.

As dificuldades de acesso apontadas, a extensa cobertura coluvionar nas partes inferiores das vertentes e no sopé da serra a Leste, além da densa vegetação e do relevo acidentado, inibem um mapeamento faciológico de detalhe (Fotos III.l e III.2). Adicionalmente, afloramentos constituídos por rochas sãs ou pouco alteradas são muito raros. Assim, parte das amostras coletadas para o presente trabalho são provenientes de matacões e/ou blocos rolados, que geralmente constituem pedreiras clandestinas exploradas pelos moradores locais para a confecção de paralelepípedos (Fotos III.3A e III.3B).

Cerca de 60 pontos foram cartografados para este trabalho (Fig. IV.l, Capitulo IV), tendo sido coletadas aproximadamente 80 amostras de rochas sieníticas, dioríticas e graníticas. Para localização mais precisa dos afloramentos foi utilizado um aparelho GPS (Sistema de Posicionamento Georeferenciado) portátil TRINBLE ${ }^{T M}$. 
A caracterização de fácies ou tipos petrográficos foi feita com base em critérios similares aos adotados para mapeamento faciológico de rochas graníticas (Vlach, 1985, 1993; Ulbrich et al., 2001), levando-se em consideração principalmente aspectos macroscópicos texturais, estruturais, mineralógicos e índice de cor, observados em amostras de mão ou nos afloramentos. 


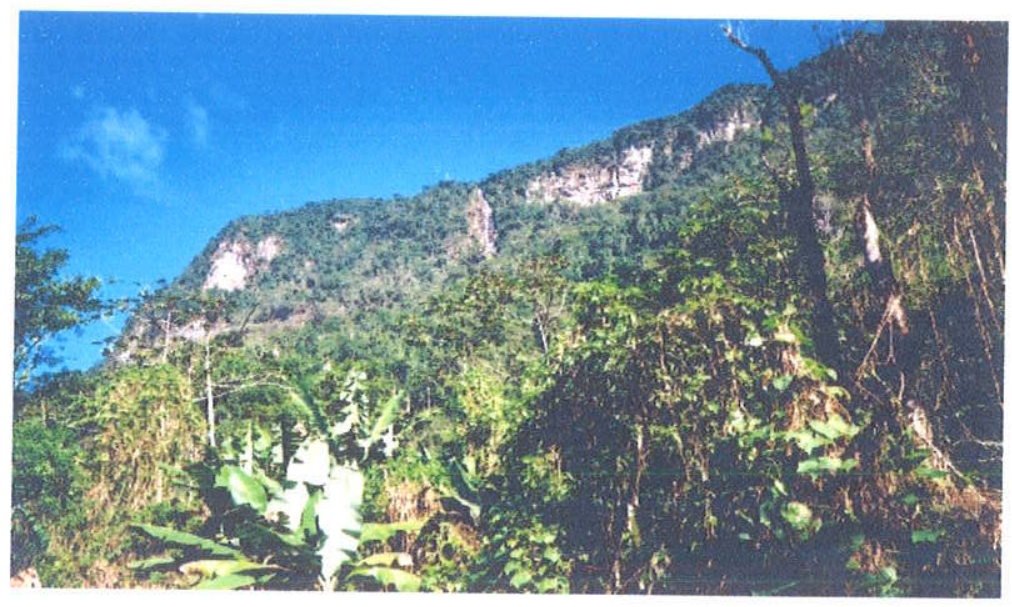

Foto III.1. Panorama do flanco leste do Maciço Corupá, destacando em primeiro plano a densa vegetação, a cobertura coluvionar em segundo plano e, principalmente, o relevo acidentado da área estudada.
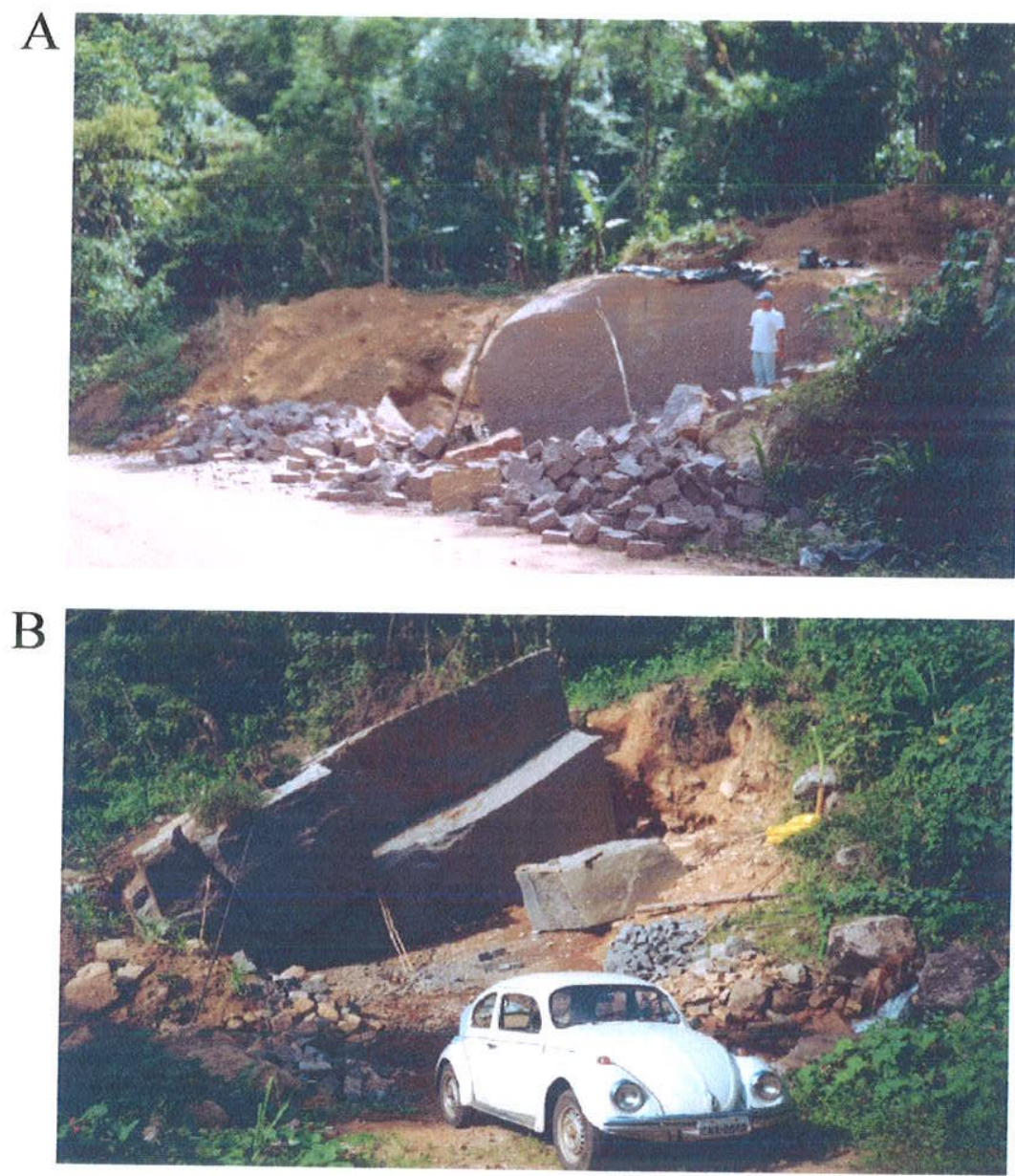

Foto III.3. Afloramentos típicos das variedades sieníticas de granulação grossa, constituídos por matacões, a amioria deles rolados, explorados clandestinamente por moradores locais.

A: matacão da variedade rósea (afloramento Co-40).

B: matacão da variedade verde (afloramento Co-50).

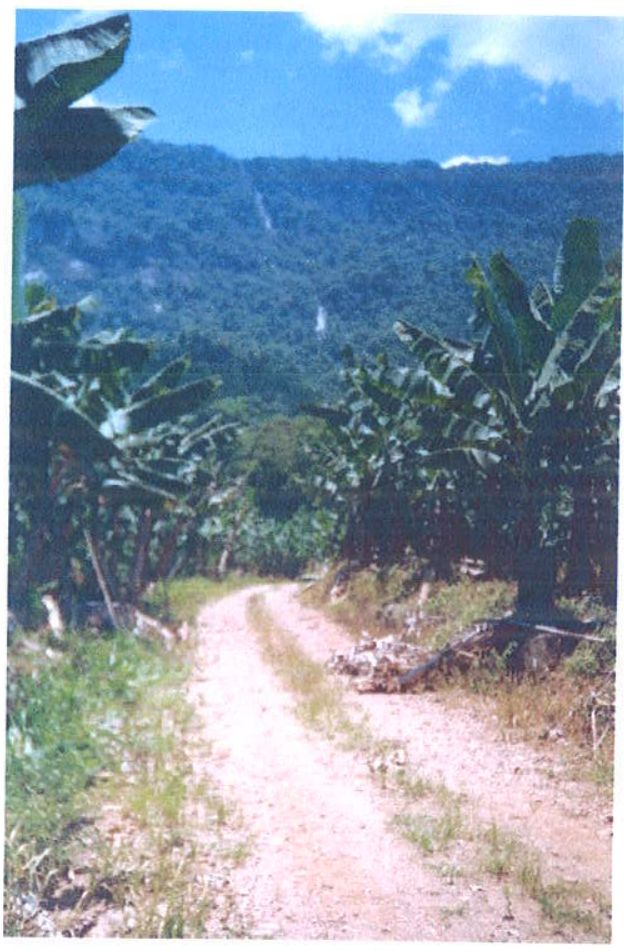

Foto III.2. Panorama da porção sudeste do maciço, ilustrando em segundo plano a densa vegetação, o relevo muito acidentado e uma das várias quedas de água da rede de drenagem da Serra do Boi. 


\section{III.2 Trabalhos em laboratório}

Os trabalhos de laboratório incluiram etapas em que foram realizadas análises petrográficas, preparação de amostras e análises químicas em minerais e rochas. Todas foram desenvolvidas nos laboratórios analíticos do Departamento de Mineralogia e Geotectônica do Instituto de Geociências da Universidade de São Paulo.

\section{III.2.1 Análises petrográficas}

Cerca de 35 seções delgadas e outras 45 seções delgadas polidas convencionais $(29 \times 49$ $\mathrm{mm}$ ) representativas das fácies petrográficas encontradas, além de algumas seções delgadas especiais $(49 \times 79 \mathrm{~mm})$ no caso das variedades de granulometria grossa foram estudadas ao microscópio petrográfico ZEISS ${ }^{T M}$-Axioplan, sob luzes transmitida e refletida.

A análise petrográfica incluiu a identificação das fases minerais presentes, com destaque para os minerais acessórios e relações texturais que permitissem estabelecer as possiveis seqüências de cristalização magmática e tardi- a pós-magmática, além de análises modais. As avaliações do teor de anortita dos plagioclásios foram feitas através do método das extinções simétricas na zona [010] em geminados segundo a Lei da Albita. As principais referências de apoio foram Mackenzie et al. (1993), Deer et al. (1992), Smith \& Brown (1988), Tröger (1979) e Wager \& Brown (1968).

Videomicrografias para ilustração e apoio para análises em microssonda eletrônica foram obtidas com um microscópio OLYMPUS ${ }^{T M}-B X 50$, ao qual encontra-se acoplada uma câmara digital MEDIA CYBERNETICSTM $3 C C D$ Pro-Series e um sistema de aquisição de imagem MEDIA CYBERNETICSTMPro-Plus. Por questão de simplificação, estas imagens foram inseridas no indice de fotomicrografias com esta denominação. Algumas fotomicrografias convencionais foram obtidas com uma câmara fotográfica OLYMPUSTMPM 20, acoplada ao mesmo microscópio.

As análises modais foram executadas com auxílio de charriot acoplado ao microscópio LEITZ ${ }^{T M}$-Wetzlar e um contador de pontos manual CLAY-ADAMS ${ }^{T M}$. A maioria das amostras 
estudadas é homogênea e apresenta estrutura maciça. No caso das rochas de granulação grossa foram considerados em média 2000 pontos por seção, distribuídos em uma malha quadrada de 1,0x1,0 mm e, em geral, os valores obtidos mostraram-se significativos. Nos casos das fácies com granulações média e fina foram considerados em média 1300 e 1000 pontos em cada seção, respecivamente $\mathrm{e}$, no último caso, considerou-se uma malha amostral de $0,5 \times 0,5 \mathrm{~mm}$. A classificação das rochas foi feita com base no diagrama modal Q-A-P, de acordo com Streckeisen (1973).

\section{III.2.2 Quimismo mineral}

Análises de quimismo mineral foram efetuadas no Laboratório de Microssonda Eletrônica, com o equipamento JEOL TM JXA 8600 Superprobe e sistema de automação NORAN TMVVyager 3.6.1. O equipamento conta com um espectrômetro de dispersão de energia (EDS) e cinco espectrômetros de dispersão de comprimentos de onda (WDS), com cristais TAP/STE, TAP/PET, LiF/PET, PET/LiF e LiF/PET, respectivamente.

Aproximadamente 20 seções delgadas polidas, representativas do conjunto de fácies petrográficas do Maciço Corupá foram cobertas com fina película de carbono $(\approx 25 \mathrm{~nm})$ com auxílio do evaporador EDWARDSTM-Auto 206 e analisadas.

Em uma primeira etapa foram obtidas imagens de eletrons retroespalhados em modo composicional (BSE-Compo) e alguns espectros de dispersão de energia para identificão de algumas fases acessórias (zircão, chevkinita, etc.). O coeficiente de retro-espalhamento depende do número atômico médio da amostra e, portanto, estas imagens ressaltam variações composicionais em escala micrométrica, permitindo destacar fases minerais diminutas e zonamentos composicionais muitas vezes não detectados em microscopia petrográfica convencional.

Uma segunda etapa envolveu análises pontuais quantitativas WDS dos minerais essenciais, através de perfís núcleo-borda, procurando-se determinar as variações composicionais mais relevantes em olivina, piroxênios, anfibólios, micas e feldspatos. As condições analíticas obedeceram às rotinas pré-estabelecidas no laboratório para cada um destes grupos minerais. No 
caso de feldspatos alcalinos, a combinação de dados pontuais com imagens BSE permitiu também integrar a composição original de intercrescimentos pertíticos (Gualda, 2001).

As condições instrumentais para a obtenção de imagens e de dados analíticos quantitativos foram $15 \mathrm{kV}$ e $20 \mathrm{nA}$ para a voltagem de aceleração e corrente do feixe eletrônico. $\mathrm{O}$ diâmetro do feixe foi fixado em 1 (obtenção de imagens) e $5 \mu \mathrm{m}$ (quantificação WDS); apenas no caso dos feldspatos alcalinos, para minimizar migrações dos metais alcalinos, particularmente $\mathrm{Na}$, foi utilizado feixe com diâmetro superior, de $10 \mu \mathrm{m}$.

Os padrões utilizados nas análises quantitativas por WDS incluiram wollastonita (Si K $\alpha$ e Ca $\mathrm{K} \alpha$ em plagioclásio e minerais máficos), microclina Asbestos ( $\mathrm{Si} \mathrm{K} \alpha$ em feldspatos alcalinos), albita Amélia (Na K $\alpha$ ), rutilo (Ti K $\alpha$ ), anortita (Al K $\alpha$ ), hornblenda Arenal (Al K $\alpha$ em anfibólios), olivina (hortonolita, $\mathrm{Fe} \mathrm{K} \alpha$ e $\mathrm{Mn} \mathrm{K} \alpha$ ), diopsídio ( $\mathrm{Mg} \mathrm{K} \alpha$ ), $\mathrm{ZnO}(\mathrm{Zn} \mathrm{K} \alpha)$, barita (Ba $L \alpha)$, zircão $(\mathrm{Zr} L \alpha)$, Sr-anortita $(\operatorname{Sr} \mathrm{L} \alpha)$, apatita $(\mathrm{Cl} K \alpha)$ e fluorita $(\mathrm{F} K \alpha)$, conforme registrados no laboratório. Os tempos totais de integração de pulsos nas análises quantitativas, repartidos igualmente entre contagem de pico e de fundo, variaram de $20 \mathrm{~s}$ (elementos maiores) a 50s (alguns menores ou traços).

Os efeitos de matriz (número e absorção atômicos e fluorescência secundária) foram corrigidos através da sistemática $P R O Z A^{T M}$ que integra o conjunto de programas analíticos Voyager. O tratamento dos dados de quimismo mineral obtidos (cálculos de proporções catiônicas, fórmulas estruturais, etc.) foi efetuado com auxilio dos programas MinPet (Richard, 1995) e MinCal (Gualda \& Vlach, inédito). A repartição do $\mathrm{Fe}^{\mathrm{T}}$ medido em microssonda em $\mathrm{Fe}^{2+}$ e $\mathrm{Fe}^{3+}$ foi feito de acordo com Droop (1987) para os piroxênios e, no dos anfibólios, considerando o máximo $\mathrm{Fe}^{3+\cdot}$ encontrado pelo método de Schumacher (1997) (Gualda \& Vlach, inédito).

\section{III.2.3 Análises químicas em rocha total}

Foram selecionadas 13 amostras entre as rochas sieníticas, dioríticas e graníticas. $O$ número reduzido de amostras analisadas é devido essencialmente a grande dificuldade de se coletar amostras sãs, como salientado anteriormente. 
Foram analisados através de espectrometria de fluorescência de raios $\mathrm{X}$ (FRX) e de espectrometria de emissão atômica com fonte de plasma induzido (ICP-AES) os elementos maiores e menores convencionais, além de $\mathrm{Ba}, \mathrm{Be}, \mathrm{Cl}, \mathrm{Co}, \mathrm{Cr}, \mathrm{Cu}, \mathrm{F}, \mathrm{Ga}, \mathrm{La}, \mathrm{Nb}, \mathrm{Nd}, \mathrm{Ni}, \mathrm{Pb}$, $\mathrm{Rb}, \mathrm{S}, \mathrm{Sc}, \mathrm{Sr}, \mathrm{Th}, \mathrm{U}, \mathrm{V}, \mathrm{Y}, \mathrm{Zn}$ e Zr. Neste trabalho, são apresentados os resultados analíticos de ICP-AES para os elementos maiores, menores, e Ba, Be, Cl, La, Nb, Nd, Sc, Sr, Th, U e Y. Os resultados de $\mathrm{Co}, \mathrm{Cr}, \mathrm{Cu}, \mathrm{F}, \mathrm{Ga}, \mathrm{Ni}, \mathrm{Pb}, \mathrm{Rb}, \mathrm{S}, \mathrm{V}, \mathrm{Zn}$ e $\mathrm{Zr}$ apresentados, foram obtidos por $\mathrm{FRX}$, pois mostraram-se mais condizentes com o esperado para as rochas analisadas.

\section{III.2.3.1 Preparação das amostras}

As amostras foram preparadas nas dependências do Laboratório de Tratamento de Amostras. Os trabalhos consistiram de fragmentação das amostras coletadas (cerca de 0,5 a 2,5 $\mathrm{kg}$, em função da granulometria) com marreta e separação dos pedaços com sinais de alteração superficial. Os fragmentos foram cominuídos em britador de mandíbulas e, em seguida, o material resultante foi quarteado progressivamente com quarteador em " $\mathrm{x}$ " (Jones) até obter-se cerca de $100 \mathrm{~g}$ de material representativo. Uma alíquota deste material foi pulverizada para uma granulometria de aproximadamente 200 mesh, em moinho anelar de ágata da marca FRITCH ${ }^{\mathrm{rM}}$.

Foram preparadas pastilhas prensadas e fundidas. As pastilhas prensadas, utilizadas nas análises de elementos traços por FRX, foram confeccionadas, sem moagem adicional, em uma prensa HERZOG ${ }^{\mathrm{TM}}$. Utilizou-se parafina como base para sustentação da pastilha (relação parafina/amostra ca. de 2:1). As pastilhas fundidas foram preparadas em um aparelho de fusão modelo CLAISSE ${ }^{\mathrm{TM}}-F_{\text {F }}$ Lxy utilizando-se como fundente uma mistura de metaborato de lítio $\left.(\mathrm{LiBO})_{2}\right)$ tetraborato de lítio $\left(\mathrm{Li}_{2} \mathrm{~B}_{4} \mathrm{O}_{7}\right)(35: 65)$ em uma relação mistura fundente/amostra 9:1.

\section{III.2.3.2 Fluorescência de Raios $X$}

As análises por espectrometria de fluorescência de raios $\mathrm{X}$ foram realizadas no

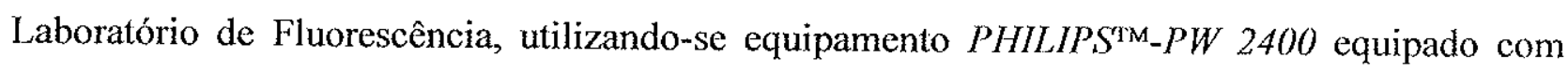
tubo de Rh. Os detalhes dos procedimentos analítico-instrumentais são apresentados e discutidos em Mori et al. (1999). As pastilhas fundidas foram utilizadas para a análise de elementos 
maiores, com finalidades comparativas em relação às equivalentes obtidas através de ICP-AES, enquanto que as prensadas foram utilizadas para a análise dos elementos traços, com destaque para aqueles que não podem ser determinados adequadamente através de ICP-AES.

III.2.3.3 ICP-AES

As análises químicas das amostras estudadas foram realizadas no Laboratório de Química e ICP-AES com o equipamento $A R L^{\mathrm{TM}}-3410$. Cerca de $2,0 \mathrm{~g}$ das amostras foram pesados em cadinhos de porcelana e então colocados em estufa à temperatura de $110^{\circ} \mathrm{C}$ por um período de 1 hora. Após a secagem separou-se $0,25 \mathrm{~g}$ de cada amostra para para realização da fusão sendo o pó restante utilizado para determinação da perda ao fogo (LOI) pelo método de gravimetria. $O$ material restante foi depositado em um cadinho e colocado em mufla à temperatura de $1000{ }^{\circ} \mathrm{C}$ por um período de 1 hora. Após este período a amostra foi resfriada até atingir a temperatura ambiente e, posteriormente, pesada. A perda ao fogo foi calculada pela diferença entre as massas inicial $(1,75 \mathrm{~g})$ e final da amostra.

Para as determinações analíticas elementais, as alíquotas de $0,25 \mathrm{~g}$ previamente secas e reservadas foram pesadas em cadinhos de porcelana. Adicionou-se $0,75 \mathrm{~g}$ de uma mistura fundente composta por metaborato de lítio $\left(\mathrm{LiBO}_{2}\right) /$ tetraborato de lítio $\left(\mathrm{Li}_{2} \mathrm{~B}_{4} \mathrm{O}_{7}\right)(4: 1)$. A mistura foi homogeneizada, transferida para cadinho de grafite e fundida em mufla à temperatura de $1000{ }^{\circ} \mathrm{C}$ por 20 minutos. Após resfriamento, a mistura foi solubilizada em solução de $\mathrm{HNO}_{3}$ $2 \mathrm{~N}$. Os detalhes dos procedimentos analítico-instrumentais, bem como procedimentos de correção de drift instrumental são apresentados e discutidos em Janasi et al. (1995). 


\section{Capítulo IV}

Geologia e Petrografia do Maciço Corupá 


\section{IV.1 Aspectos Geológicos do Maciço Corupá}

As rochas que constituem o Maciço Corupá incluem variedades de álcali-feldspato sienitos supersaturados, álcali-feldspato granitos e de algumas variedades dioríticas e de rochas híbridas associadas. Algumas das características geológicas gerais do Maciço são apresentadas e discutidas a seguir.

\section{IV.1.I Variedades petrográficas: caracterização, estruturas e distribuição}

Os dados de campo obtidos no decorrer deste trabalho, bem como os já existentes na literatura (Chiessi et al., 1998; Kaul; 1997; Oliveira; 1997), mostram que as rochas sieníticas são amplamente predominantes em relação às rochas graníticas, enquanto que os dioritos e as rochas híbridas são bem raros, estas últimas aparecendo apenas como enclaves. Desta forma a denominação "Granito Corupá", tal como utilizada até o presente (Kaul, 1997; Albuquerque et $a l ., 1971)$ não parece ser a mais apropriada, preferindo-se aqui empregar o termo Maciço Corupá.

Seis fácies sieníticas e uma granítica, além das rochas dioríticas e híbridas, cujas características petrográficas gerais são resumidas na Tabela $I V .1$ foram individualizadas durante os trabalhos de campo e petrográficos. No mapa geológico (Figura IV.1) estas fácies são reunidas em duas associações de fácies sieníticas, individualizadas principalmente pela sua cor, uma rósea outra verde e uma associação de rochas graníticas. As áreas de ocorrência das rochas dioríticas e híbridas estão representadas pontualmente.

As fácies sieníticas são distintas por características de cor, texturais, mineralógicas e, em parte, pelo índice de cor (IC). As mais comuns são variedades de colorạ̧ão rósea, com granulações grossas, médias e finas. A fácies de granulação grossa (sienitos róseos grossos) é leucocrática e contém anfibólio e piroxênio como minerais máficos essenciais. Em geral apresenta estrutura maciça, mas localmente, estruturas bandadas são observadas em alguns afloramentos na região centro-leste do maciço. Estas últimas são definidas por níveis de granulação média a grossa relativamente mais ricas em minerais máficos (IC até 25) que se alternam com bandas de granulação grossa com quantidades menores de minerais máficos (IC 
em torno de 10) (Foto IV.l); algumas vezes observam-se apenas bandas mais máficas irregulares e descontínuas com típico aspecto de estruturas "schilieren" (Foto IV.2). As variedades de granulações médias e finas apresentam estruturas maciças e, em geral, apresentam valores menores para o IC. Nas regiões próximas às áreas de ocorrência de rochas dioríticas, as variedades de granulação média contêm, por vezes, enclaves microgranulares máficos, subarredondados, com dimensões milimétricas a centimétricas e composição monzonítica em graus variáveis de assimilação. Em outros locais, observam-se apenas glomérulos máficos milimétricos. Nas áreas centro-sudeste do maciço foram encontradas variedades hololeucocráticas de colorações vermelhas muito intensas, provavelmente hidrotermalizadas. Os sienitos róseos finos ocorrem principalmente como diques decimétricos a métricos (Foto IV.3) e localmente como enclaves centimétricos arredondados ou mais irregulares nos sienitos róseos de granulação grossa.

Cavidades miarolíticas em geral submilimétricas são localmente encontradas nos tipos mais félsicos de granulação grossa e nas variedades médias e finas; quartzo euhedral, prismático, é freqüentemente encontrado nestas cavidades. Pequenos diques e bolsões de quartzo sienitos pegmatíticos, também com cavidades miarolíticas milimétricas a centimétricas, com quartzo druseiforme foram encontrados em um afloramento em sienitos róseos de granulação grossa.

Os sienitos de coloração verde são mais abundantes nas regiões Centro-Nordeste, com algumas ocorrências a $\mathrm{N}$ e a $\mathrm{S}$ do maciço. São estruturalmente e texturalmente similares as variedades róseas. $O$ tipo de granulação mais grossa caracteriza-se, além da cor, pela presença de olivina e pela maior abundância de piroxênio em relação ao anfibólio (ver descrições petrográficas no Item $I V .2 .4)$. Em um único local, na região NE do maciço, foi encontrada uma fácies de melasienito (IC superior a 50) com granulação média a grossa. Esta fácies ocorre tipicamente como bandas centimétricas de aspecto cumulático associadas aos sienitos verdes de granulação grossa, destacando-se em relação aos demais sienitos também por apresentar quantidades significativas de magnetita, facilmente detectável com imã de mão.

As rochas graníticas ocorrem em maior abundância nas regiões centrais e sul mais elevadas da Serra do Boi e também no extremo norte do maciço. São rochas homogêneas, com coloração rósea clara, estrutura maciça e granulação média e são hololeucocráticas, contendo 
anfibólio como mineral máfico característico. Diminutas cavidades miarolíticas são comuns nesta fácies.

As rochas dioríticas não eram conhecidas no maciço até os trabalhos preliminares de Oliveira (1997). No presente trabalho, além da confirmação das observações desta autora, foram cartografadas diversas ocorrências adicionais. Estas rochas afloram irregularmente no maciço, sendo aparentemente mais abundantes na região centro-sudeste. Nesta área ocorre um dique com espessura métrica a decamétrica com direção NW-SE e diversas ocorrências irregulares dispersas para as quais não se conseguiu determinar a forma; provavelmente também constituam diques. Adicionalmente ocorrem em alguns afloramentos na forma de enclaves dentro de rochas sieníticas de granulação média. São rochas escuras de estrutura maciça e granulações médias e finas, portadoras de biotita, além de anfibólio/piroxênio.

\section{IV.1.2 Contatos geológicos e relaçôes estruturais entre as fácies petrográficas}

Os contatos externos e internos do Maciço Corupá apresentados na Figura IV.I são apenas sugeridos devido às dificuldades de mapeá-los, face à ausência de afloramentos in situ e/ou à extensa cobertura coluvionar.

Os contatos externos do maciço com as rochas regionais do Cráton Luis Alves e com as seqüências vulcano-sedimentares da Bacia Campo Alegre correspondem em linhas gerais aos apresentados por Kaul (1997) e Daitx (1979). Rochas correlatas ao Cráton Luis Alves foram descritas nas imediaçốes dos contatos setentrionais. Tratam-se de gnaisses enderbíticos de aspecto homogêneo e gnaisses tonalíticos bandados, em parte migmatíticos. Nas imediações dos contatos meridionais do maciço afloram principalmente (meta)-argilitos e siltitos, por vezes com intercalações finas de possíveis cinzas vulcânicas. $\mathrm{O}$ acamamento destas rochas apresenta-se em geral com mergulhos baixos a moderados para S-SW. Na região centro-oeste aparecem (meta)conglomerados polimíticos ora clasto- ora matriz-suportados. Relações de contato entre estas litologias e as rochas sieníticas e graníticas do maciço não foram entretanto observadas durante os trabalhos de campo. $O$ único contato externo verificado, que aflora na região $W$ do maciço, é de natureza tectônica, com orientação aproximada N-S, colocando lado a lado sienitos de granulação grossa alterados e meta-siltitos da bacia vulcano-sedimentar (Foto IV.5). 
Contatos internos entre as variedades petrográficas individualizadas também não foram encontrados e desta forma as relações entre as fácies sieníticas de granulações grossa e média e destas com as rochas graníticas não puderam ser determinadas. Os próprios contatos esquematizados no mapa geológico (Figura IV.I) correspondem a simples aproximações baseadas em informações pontuais e, no caso das rochas graníticas da parte central do anel, também em sugestões topográficas, uma vez que em geral estas afloram em cotas mais elevadas que as em que predominam as variedades sieníticas.

A colocação das rochas sieníticas de granulação média a fina foi certamente contemporânea ou imediatamente posterior a das variedades de granulações grossas, uma vez que aparecem como diques de espessuras variáveis (Foto $I V .3$ ) e também como enclaves nas últimas.

O desenho do mapa geológico sugere que as rochas graníticas sejam algo posteriores em relação às rochas sieníticas; algumas relações de contato foram observadas apenas nas proximidades do afloramento $\mathrm{Co}-4$, onde granitos de granulação média por vezes parecem cortar os sienitos róseos de granulação grossa, ora parecem ser neles incluídos, neste caso indicando certa contemporaneidade.

Os enclaves microgranulares, em parte híbridos, e os glomérulos máficos observados nos sienitos róseos de granulação média e a presença de diques sugerem que as rochas dioríticas devem ter se colocado mais ou menos simultaneamente às rochas sieníticas, como verificado em campo (Foto IV.4), sob a forma de manifestações aparentemente sin-plutônicas .

\section{IV.1.3 Zonas de cizalhamento e de falhas}

Algumas zonas de cisalhamento e, principalmente, de falhas foram observadas e descritas durante as etapas de campo. As zonas de cisalhamento foram encontradas, em grande parte na parte $S$ do maciço cortando as variedades sieníticas róseas, entretanto suas atitudes não puderam ser medidas. 
Planos de falhas foram observados com freqüência nas áreas mais elevadas da porção central do maciço, afetando as rochas graníticas. Apresentam atitudes aproximadas N85E/65NW e N20W/35SW (Figura IV.l).

\section{IV.1.4. Diques de microgranitos}

Diques micrograníticos com granulações finas foram encontrados na área mapeada, em alguns pontos in situ periféricos ao maciço, cortando rochas gnáissico-granulíticas do embasamento e sienitos róseos (Figura IV.1). Alguns blocos destes microgranitos foram também encontrados em meio a blocos de rochas sieníticas nas seqüências coluvionares.

Ocorrências similares, associadas mais claramente à Bacia Campo Alegre (Daitx, 1979), permitem sugerir que estes microgranitos estejam relacionados a seqüência vulcânica da bacia $\mathrm{e}$ não diretamente ao Maciço Corupá. Em uma das localidades, o contato entre estas rochas e o sienito róseo exibe atitude $\mathrm{N} 10^{\circ} \mathrm{E}$ com mergulho médio $\left(45^{\circ}\right)$ para $\mathrm{SE}$. 


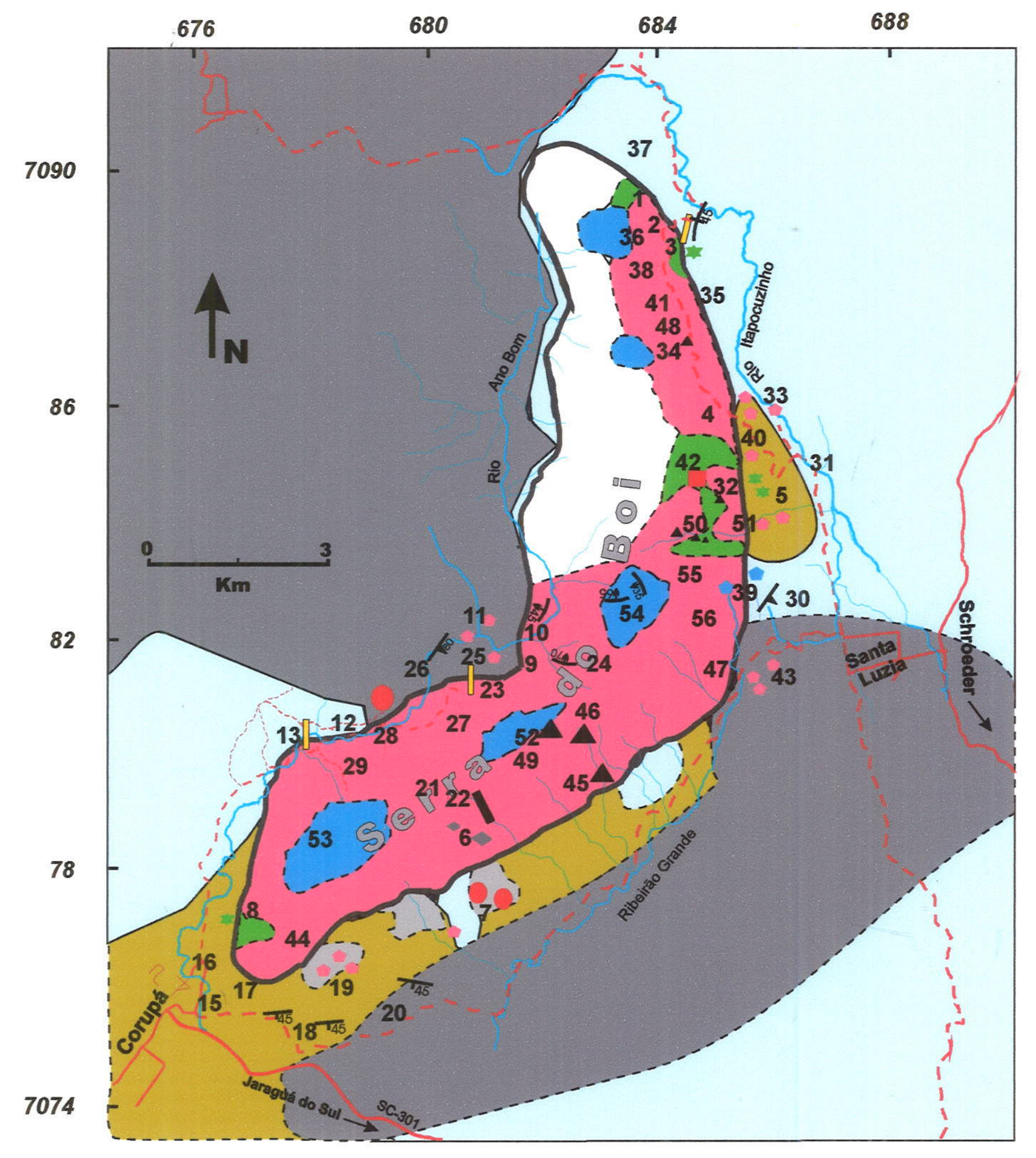

Figura VI.1. Mapa geológico esquemático, ilustrando a distribuição das fácies petrográficas no Maciço Corupá.

Contatos externos baseados em Daitx (1979).

\section{Legenda}

Unidades Geológicas

\section{Holoceno}

Cobertura coluvionar

\section{Neoproterozóico}

Dique granítico

Bacia vulcano-sedimentar Campo Alegre

Maciço Corupá

$\square$ Fácies granítica

Fácies sieníticas rósea

Fácies sieníticas verde

Fácies melasienítica

1 Dique diorítico

$\triangle$ Fácies monzodiorítica

Enclaves monzoníticos

$\square$ Área inacessível

Blocos rolados rochas gran/ticas

Blocos rolados rochas sieníticas róseas

- Blocos rolados rochas sieníticas verdes

Arqueano-Paleoproterozóico

$\square$ Ganisses-granulitos Cráton Luis Alves

[O Blocos rolados embasamento

\section{Estruturas}

TDireção e mergulho acamamento

$\checkmark$ Direção e mergulho foliação

T Direção e mergulho falhas

-Direção e mergulho contatos litológicos

\section{Convenções}

$\sim$ Drenagem

Estradas principais

- Estradas secundárias

- Contatos sugeridos

Contorno aproximado do maciço

Localização e Articulação da Folha Jaraguá do Sul (1:50000)

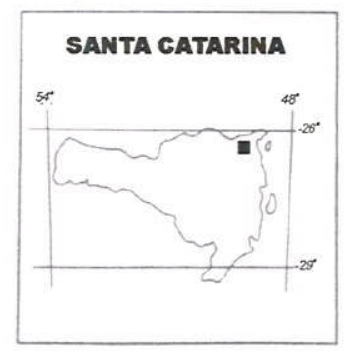

\begin{tabular}{|c|c|c|}
\hline $\begin{array}{l}\text { Campo } \\
\text { Clager } \\
\text { ML-2069/1 }\end{array}$ & 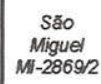 & M-287o/ \\
\hline 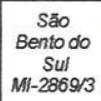 & 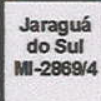 & 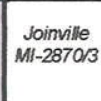 \\
\hline 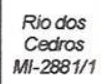 & 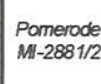 & \\
\hline
\end{tabular}




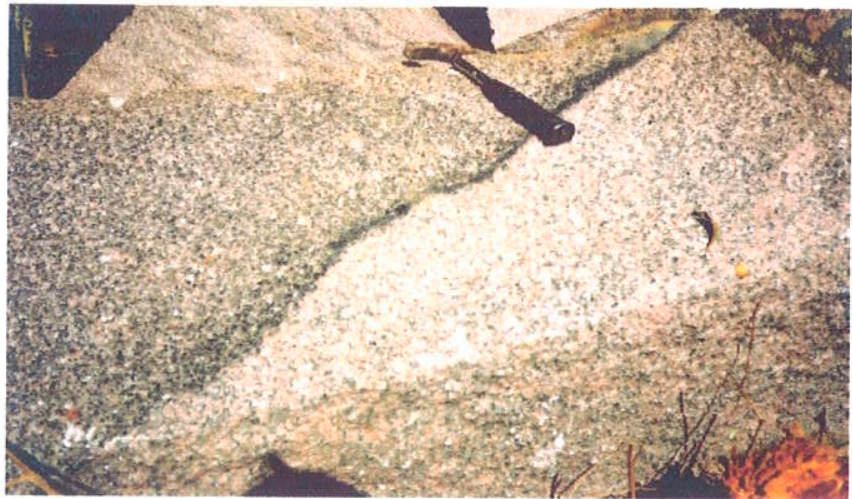

Foto IV.1. Bloco de sienito róseo de granulação grossa ilustrando bandamento de tipo "schilieren", com bandas mais ricas em minerais máficos discordantes des bandas sieníticas róseas. Proximidades do afloramento Co-34.

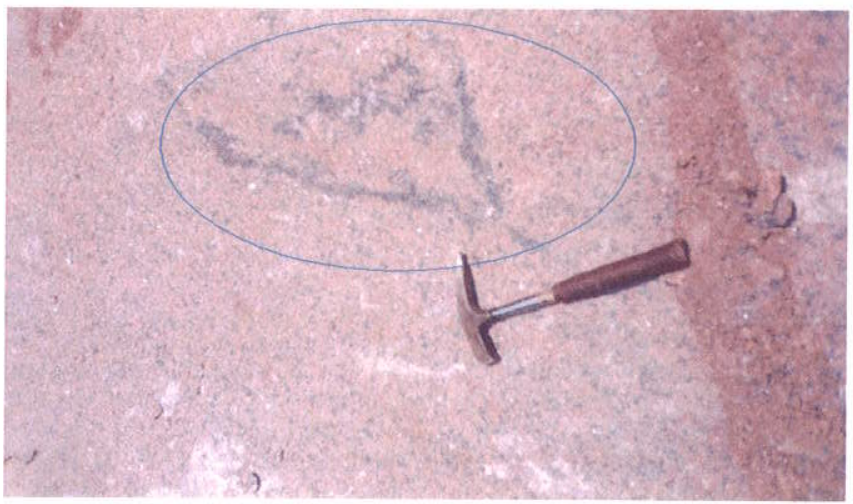

Foto IV.2. Sienito róseo e granulação grossa mostrando pequenos "schilierens" máficos irregulares (proximidades do afloramento $\mathrm{Co}-32$ ).

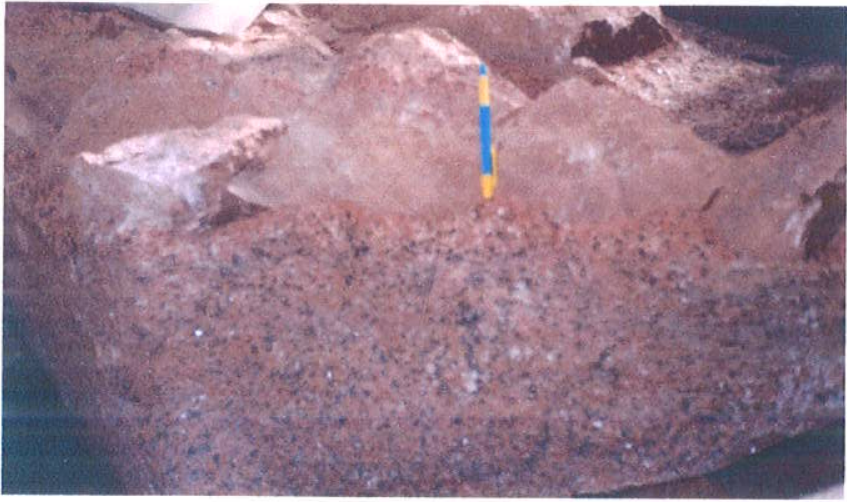

Foto IV.3. Dique decimétrico de sienito róseo de granulação fina cortando a fácies sienítica rósea de granulação grossa (afloramento Co-40).

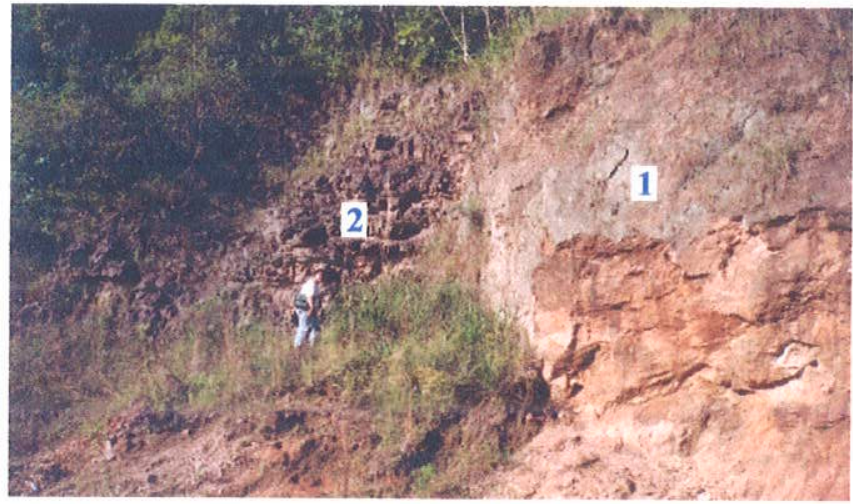

Foto IV.5. Contato tectônico entre variedade sienítica muito alterada e meta-siltito da bacia vulcano-sedimentar de Campo Alegre. Borda Oeste do maciço, afloramento Co-

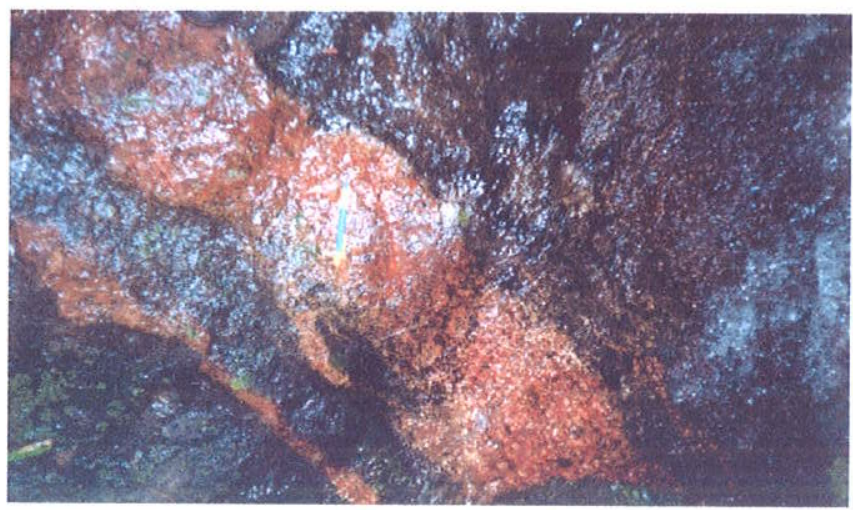

Foto IV.4. Contato irregular entre fácies sienítica rósea de granulação média e rocha diorítica, sugestivo de certa contemporaneidade de colocação (afloramento Co-49). 
Tab. IV.1: Resumo das principais características dos fácies petrográficos encontrados no Maciço Corupá.

\begin{tabular}{|c|c|c|c|c|c|c|c|c|}
\hline $\begin{array}{c}\text { Fácies } \\
\text { Perográfica }\end{array}$ & Cor & Estrutura & Textura & Granulometria & $I C$ & $\begin{array}{l}\text { Minerais } \\
\text { Máficos }^{(1)}\end{array}$ & $\begin{array}{l}\text { Minerais } \\
\text { Opacos }^{(1)}\end{array}$ & Observações \\
\hline $\begin{array}{l}\text { Granito } \\
\text { médio }\end{array}$ & Rosa-clara & Maci̧̧a & $\begin{array}{l}\text { Equigtanular, } \\
\text { hipidiomórfica }\end{array}$ & $\sim 2,0 \mathrm{~mm}$ & 5 & Cam & Ilm, Hem & $\begin{array}{c}\text { Contém cavidades } \\
\text { miaroliticas }\end{array}$ \\
\hline $\begin{array}{l}\text { Sienito róseo } \\
\text { grosso }\end{array}$ & Rosa & Maciça & $\begin{array}{l}\text { Inequigranular, } \\
\text { hipidiomórfica }\end{array}$ & $5,0-20,0 \mathrm{~mm}$ & $10-15$ & Cam, Cpx & Ilm, Hem & $\begin{array}{l}\text { "Schlierens" máficos. } \\
\text { Contem veios } \\
\text { pegmatíticos com } \\
\text { mesma composição }\end{array}$ \\
\hline $\begin{array}{l}\text { Sienito róseo } \\
\text { médio }\end{array}$ & Rosa & Maciça & $\begin{array}{c}\text { Equigranular, } \\
\text { hipidiomórfica }\end{array}$ & $\sim 1,5 \mathrm{~mm}$ & $10-12$ & Cam, Cpx & $\mathrm{Ilm}, \mathrm{Hem}$ & $\begin{array}{c}\text { Contem enclaves } \\
\text { monzoníticos e } \\
\text { monzodioriticos, além } \\
\text { de cavidades } \\
\text { miarolíticas. }\end{array}$ \\
\hline $\begin{array}{c}\text { Sienito róseo } \\
\text { fino }\end{array}$ & Rosa & Maciça & $\begin{array}{l}\text { Equigranular, } \\
\text { hipidiomórfica }\end{array}$ & $\sim 0,5 \mathrm{~mm}$ & 5 & Cam, Cpx & $\lim$ & \\
\hline $\begin{array}{l}\text { Sienito verde } \\
\text { grosso }\end{array}$ & $\begin{array}{c}\text { Verde-clara } \\
\text { a escura }\end{array}$ & Maciça & $\begin{array}{l}\text { Inequigranular, } \\
\text { hipidiomórfica }\end{array}$ & $5,0-20,0 \mathrm{~mm}$ & $10-15$ & $\mathrm{Cam}, \mathrm{Cpx}, \mathrm{Ol}, \mathrm{Bt}$ & Ilm, Hem & \\
\hline $\begin{array}{l}\text { Sienito verde } \\
\text { médio }\end{array}$ & Verde-clara & Maciça & $\begin{array}{l}\text { Equigranular, } \\
\text { hipidiomórfica }\end{array}$ & $\sim 4,0 \mathrm{~mm}$ & $5-10$ & $\mathrm{Cpx}, \mathrm{cam}$ & Ilm, Hem & $\begin{array}{l}\text { Contem cavidades } \\
\text { miarolíticas }\end{array}$ \\
\hline Melasienito & Preta & Maciça & $\begin{array}{l}\text { Inequigranular, } \\
\text { hipidiomórfica }\end{array}$ & $4,0-10,0 \mathrm{~mm}$ & $>50$ & $\mathrm{Ol}, \mathrm{Cpx} ., \mathrm{Bt}$, Cam & Ilm, Mag & $\begin{array}{l}\text { Ocorre associado ao } \\
\text { sienito verde grosso }\end{array}$ \\
\hline $\begin{array}{l}\text { Dioritos e } \\
\text { rochas } \\
\text { híbridas }\end{array}$ & $\begin{array}{c}\text { Cinza } \\
\text { escura e } \\
\text { cinza } \\
\text { azulado } \\
\end{array}$ & Maciça & $\begin{array}{l}\text { Equigranular, } \\
\text { hipidiomórfica }\end{array}$ & $0,1-5,0 \mathrm{~mm}$ & $\begin{array}{l}15-20(\mathrm{f}) \\
10-15(\mathrm{~m})\end{array}$ & $\mathrm{Cpx}, \mathrm{Cam}, \mathrm{Bt}$ & Ilm, Mag & $\begin{array}{l}\text { Ocorre sob forma de } \\
\text { diques e/ou corpos } \\
\text { irregulares }\end{array}$ \\
\hline Monzonito & Cinza claro & Maciça & $\begin{array}{l}\text { Equigranular, } \\
\text { hipidiomórfica }\end{array}$ & $\sim 2,0 \mathrm{~mm}$ & 10 & $\mathrm{Cpx}, \mathrm{Cam}, \mathrm{Bt}$ & Ilm, Mag & $\begin{array}{l}\text { Ocorre como enclaves } \\
\text { em sienito róseo médio. } \\
\text { Caracteristicas híbridas. }\end{array}$ \\
\hline
\end{tabular}

(1) Abreviaturas segundo Kretz (1983) 


\section{IV.2 Petrografia}

Apresenta-se a seguir uma breve descrição das fácies petrográficas mapeadas no Maciço Corupá, bem como informações modais e seqüências de cristalização inferidas a partir de critérios texturais. Os dados modais são sintetizados na Tabela IV.2 e nas Figuras IV.2 e IV.3. As Figuras $I V .4, I V .5$ e $I V .6$ apresentam quadros ilustrativos das seqüencias de cristalização inferidas para os principais tipos petrográficos.

\section{IV.2.1 Microgranitos}

São rochas leucocráticas de dique, com colorações róseo-avermelhadas com estrutura maciça, equigranulares com granulação fina. Modalmente correspondem a álcali-feldspato granitos com feldspato alcalino como única fase feldspática primária. Em seção delgada, são muito homogêneos, apresentando em essência feldspato alcalino, quartzo, clinopiroxênio e minerais opacos, regularmente distribuídos. Mineralogicamente contrastam com os álcali-feldspato granitos mais típicos do maciço pela presença de clinopiroxênio e ausência de anfibólio.

A textura é hipidiomórfica equigranular, dominada pelo feldspato alcalino $(0,5-1,5 \mathrm{~mm})$ subidiomórfico a xenomórfico, pertítico, com forte coloração castanha-avermelhada devida à intensa alteração. $O$ quartzo $(<1,0 \mathrm{~mm})$ aparece límpido, intersticial e, principalmente, na forma de intercrescimentos granofíricos, particularmente nas bordas do felspato alcalino. Em geral apresenta extinção ondulante.

Clinopiroxênio é o máfico predominante, ocorrendo como cristais xenomórficos a subidiomórficos $(0,1-1,5 \mathrm{~mm})$ com pleocró́smo variando de bege esverdeado $(X)$ a verde $(Y)$. Ocorre também bastante alterado e é relativamente rico em inclusões primárias de minerais opacos.

Minerais de alteração incluem provável hematita e sericita associadas aos feldspatos alcalinos e minerais opacos associados ao piroxênio. 


\section{IV.2.2 Granitos de granulação média}

São rochas homogêneas com estruturas maciças, por vezes com cavidades miarolíticas bem definidas, vazias ou com cristais idiomórficos bem desenvolvidos. São hololeucocráticas, com colorações cinzentas a róseas mais claras em função do grau de alteração (Fotos $1 V .6$ e IV.7) $e$ correspondem a álcali-feldspato granitos com quantidades variáveis de quartzo e máficos (Figuras IV.1 e IV.2).

Ao microscópio são rochas homogêneas, com texturas equigranulares xenomórficas a hipidiomóricas granofíricas. A mineralogia é simples, constituída por feldspato alcalino como fase feldspática primária única, quartzo e anfibólio sódico e pequena quantidade de minerais acessórios. Nas cavidades miarolíticas são, por vezes, encontrados cristais de quartzo bem formados, prismáticos, e minerais acessórios de cristalização hidrotermal, com destaque para allanita rica em Fe e epidoto (Vlach, 1999).

O feldspato alcalino $(0,5-3,0 \mathrm{~mm})$ é xenomórfico a subidiomórfico e geminado segundo a Lei de Carlsbad. Aparece em geral com aspecto "sujo" dado por possível alteração para argilominerais e é mesopertítico, com "filmes" de albita mais límpida (Fotomicrografia IV.24).

O quartzo $(0,5-2,0 \mathrm{~mm})$ aparece como cristais maiores isolados e limpidos, por vezes com formas bipiramidadas sugestivas de cristalização do polimorfo $\beta$ e leve extinção ondulante, além de, freqüentemente, constituir intercrescimentos granofíricos com o feldspato alcalino, em geral, como bordas sobrecrescidas em feldspatos homogêneos, nos quais o quartzo, de aspecto cuneiforme, cristaliza radialmente a partir destes feldspatos. Os eontatos entre os intercrescimentos granofíricos são irregulares e interpenetrados.

O mineral máfico típico destas rochas é o anfibólio cálcio-sódico a sódico. Apresenta dimensões entre 0,8 e $2,0 \mathrm{~mm}$, com os cristais menores aparecendo intersticialmente a feldspato e quartzo. Em geral aparece zonado, particularmente os cristais maiores, com pleocroísmo variando de azul esverdeado $(X)$ a marron claro $(Y)$ nos núcleos dos grãos a azul escuro $(X)$ e marron $(Y)$ nas 
bordas; os ângulos de extinção $z^{\wedge} \mathrm{c}$ variam de $15^{\circ}$ a $25^{\circ}$ do núcleo para as bordas. Estes padrões sugerem núcleos de anfibólio cálcio-sódico e bordas de anfibólio sódico, provavelmente riebeckita (Videomicrografias IV.I, IV.2 e IV.3).

Entre os minerais acessórios, a ilmenita $(<0,8 \mathrm{~mm}$, subidiomórfica) aparece como o mineral opaco típico, ocorrendo ora isolada, ora como inclusões no anfïbólio. Em geral, exibe finas lamelas regulares de hematita exsolvida. Zircão e apatita (mais raros) ocorrem como cristais límpidos e idiomórficos $(0,2-0,5 \mathrm{~mm})$. A chevkinita-perrierita $(0,3-0,8 \mathrm{~mm}$, confirmada com EDS), apresenta-se pleocróica em tons de amarelo-alaranjado a marron escura, ocorrendo interesticialmente ou como inclusões em anfibólio (Fotomicrografia IV.3). Fluorita incolor a violácea, intersticial e com formas irregulares, pouco abundante, aparece em algumas seções.

Albita tardi- e pós-magmática, límpida e muito pura $\left(\mathrm{An}_{n}<3\right)$, ocorre como agregados irregulares ou cristais mais desenvolvidos intersticiais ao feldspato alcalino (Fotomicrografia IV.24). Minerais tardios, provavelmente hidrotermais em micromiárolas, incluem além de allanita e epidoto, possível zircão formando agregados irregulares concêntricos, minerais opacos e um filossilicato de coloração vermelha alaranjada não identificado.

\section{IV.2.3 Sienitos róseos de granulação grossa}

São rochas cuja trama textural hipidiomórfica a porfiróide é definida pelo arranjo irregular dos feldspatos alcalinos tabulares com tonalidades róseas de maior ou menor intensidade e dimensões entre 2,0 e 25,0 mm (Foto IV.8). Os minerais máficos aparecem ora como cristais maiores isolados, ora em agregados máficos intersticiais. Modalmente correspondem a álcalifeldspato sienitos e álcali-feldspato quartzo sienitos, estes últimos com quantidades menores de minerais máficos (Fotos IV.9 e IV.IO) (Figuras IV.l e IV.2). Uma amostra incluída neste grupo corresponde a uma variedade com granulação pouco menor que apresenta evidências de alteração hidrotermal mais marcada, com coloração marron-avermelhada muito intensa (amostra Co-9A). 
O feldspato alcalino é também a única fase feldspática primária. Apresenta-se subidiomórfico com contatos intercristalinos retos ou interpenetrados. A geminação típica corresponde à Lei de Carlsbad. Algum zonamento composicional é evidenciado pela variação do padrão de extinção e pela concentração variável de albita pertítica. As lamelas de albita pertítica têm morfologias variadas, aparecendo ora como lamelas mais espessas e irregulares, ora em filmes mais finos e regulares (mais comum), ora ainda como "cardumes" de pequenos filmes; com alguma freqüência são mais concentradas nas bordas do hospedeiro. A coloração rósea a avermelhada é dada em grande parte por inclusões diminutas de hematita, que são bem mais abundantes na amostra Co-9A.

$\mathrm{O}$ quartzo $(<2,0 \mathrm{~mm})$ é xenomórfico, intersticial e aparece isolado ou em agregados de poucos grãos. Intercrescimentos granofíricos em zonas marginais de feldspatos alcalinos são ocasionais (Fotomicrografia IV.26).

Anfibólio $(0,3-2,0 \mathrm{~mm})$ é, em geral, o mineral máfico dominante nestas rochas. Aparece como cristais subidiomórficos a idiomórficos, por vezes com geminação simples, com os cristais maiores ocorrendo isoladamente e os menores constituindo agregados intersticiais. Apresenta zonamento composicional normal ou recorrente, nos núcleos dominando tons pleocróicos de verde claro (X) a marrom-claro ou bege (Y) e bordas com verde escuro (X) a bege esverdeado (Y) (Fotomicrografia $I V .4$ ), chegando a tons mais azulados em $(\mathrm{X})$ na amostra Co-4B, evidenciando já uma variedade cálcio-sódica. $\mathrm{O}$ ângulo $z^{\wedge} \mathrm{c}$ oscila entre $20^{\circ}$ e $35^{\circ}$ do núcleo para as bordas. Apresenta raramente alguns núcleos corródos de clinopiroxênio e outras vezes está parcialmente manteado por uma fina camada de biotita tardia.

O clinopiroxênio $(0,5-2,0 \mathrm{~mm})$ é idiomórfico a subidiomórfico e aparece como cristais prismáticos isolados ou nos agregados com os demais minerais máficos. Ocorre tipicamente em duas gerações texturais distintas. A primeira, relativamente precoce, possui pleocroísmo incipiente em tons róseos claros, com $\mathrm{z}^{\wedge} \mathrm{c}$ da ordem de $38^{\circ}$ a $42^{\circ}$. A segunda, mais tardia, aparece substituindo a primeira nas bordas dos grãos ou ao longo das clivagens e mostra pleocroísmo bem marcado $(X=$ verde, $Y=$ marron-esverdeado claro), com $Z^{\wedge} \mathrm{c}$ próximo a $55^{\circ}$, indicando composição 
significativamente mais rica na molécula hedenbergítica (Fotomicrografias $\mathrm{IV} .11, \mathrm{~W} .12$ e IV.I3). Esta segunda geração é mais comum nos agregados máficos e, com alguma freqüência encontra-se por sua vez manteada por anfibólio cálcico, biotita (rara) e/ou minerais opacos. As inclusões mais comuns são de apatita e minerais opacos

O mineral opaco característico destas variedades é a ilmenita $(0,5-1,5 \mathrm{~mm})$ idiomórfica a subidiomórfica, que apresenta lamelas mais ou menos regulares de exsolução de hematita. $\mathrm{Na}$ amostra Co-9A a hematita é abundante e aparece também substituindo a ilmenita em planos de fratura. Os acessórios típicos incluem, apatita abundante $(0,1-1,0 \mathrm{~mm})$, zircão $(0,5-1,5 \mathrm{~mm})$ e chevckinita-perrierita $(0,1-0,5 \mathrm{~mm})$, idiomórficos. Ocorrem junto aos agregados máficos e como inclusões nos demais minerais, particularmente anfibólio.

Minerais tardi- a pós-magmáticos máficos incluem anfibólio actinolítico que aparece como cristais aciculares ou em agregados fibro-radiados incolores a levemente pleocróicos em tons de verde (Fotomicrografia $(V .5)$, associados a agregado intersticiais que preenchem espaços entre os cristais tabulares de feldspato alcalino, junto com biotita subidiomónfica $(<1 \mathrm{~mm})$ de tonalidades castanho-avermelhadas, material cloritico, argilominerais, carbonatos e minerais opacos (magnetita, hematita e não identificados). Alguns destes minerais ocorrem também alterando os minerais máficos primários. Os félsicos correspondem essencialmente à albita, que ocorre ora como mantos irregulares, ora como grãos subidiomófficos límpidos, bem geminados, intersticiais aos cristais de feldspato alcalino. Albita tipo "chessboard" aparece em algumas seções (Fotomicrografia WV.25).

\section{IV.2.4 Sienitos verdes de granulação grossa}

Estas variedades são também álcali-feldspato sienitos e quartzo sienitos com características estruturais, texturais e modais bastante similares às variedades róseas. Os maiores contrastes estão na coloração verde dos feldspatos alcalinos $(2,0$ a $25,0 \mathrm{~mm})$ e na presença de olivina entre os minerais máficos e na maior abundância de clinopiroxênio em detrimento ao anfibólio e aos minerais opacos. Por vezes, os agregados máficos ocorrem sob forma granular (Fotos IV.15). 
Cristais isolados de clinopiroxênio podem ser observados, perfeitamente, em amostras mesoscópicas (Foto IV.16).

A textura é igualmente hipidiomórfica inequigranular a porfiróide e as características texturais e micro-estruturais do feldspato alcalino e do quartzo são muito parecidas, conquanto os intercrescimentos de tipo gráfico entre ambos sejam bem menos comuns.

O clinopiroxênio idiomórfico a subidiomórfico $(1,0-3,0 \mathrm{~mm})$ é o máfico mais abundante nestas variedades aparecendo também na forma de uma geração anterior salítica com pleocroísmo incipiente em tons de rosa e outra posterior, hedenbergitica, que ocorre como mantos verdes, anéis parciais e substituindo a primeira irregularmente ao longo dos planos de clivagem (Fotmicrografia $(V .14)$. Os cristais de primeira geração apresentam, por vezes, zonas internas de clinopiroxênio incolor e diminutas inclusões regulares de minerais opacos ao longo de planos de partição (Fotmicrografia 1 . 15 ). Os cristais inclusos em feldspato são em geral os da primeira geração. Geminação simples e inclusões de opacos e apatita são comuns a ambas as geraçôes. Mantos de anfibólio ocorrem sobre o clinopiroxênio de segunda geração ou, mais raramente, diretamente sobre o de primeira geração (Fotomicrografia $W$. 16).

O anfíbólio cálcico apresenta propriedades morfológicas e de pleocroísmo semelhantes às descritas para a variedade rósea. Não aparecen entretanto os tipos com tonalidades azuladas mais fortes e restos corroídos de clinopiroxênio nos núcleos dos cristais são mais comuns.

A olivina faialítica $(0,8-2,5 \mathrm{~mm})$ é subordinada e aparece em geral como cristais subidiomórficos a xenomórficos isolados. Finos intercrescimentos "simplectíticos" derivados por possível exsolução de minerais opacos são comuns à maioria dos grãos mais preservados. Apresenta $2 V_{x}$ en tomo de $40^{\circ}$, está sempre muito fraturada e com freqüencia parcialmente substituida por clinopiroxênio verde, anfibólio, clorita, opacos e finos agregados não identificados. Em alguns casos são observados apenas pseudomorfos subarredondados de tons laranja-avermelhados, marrons e/ou, como é mais comum, verde-escuros, constituídos por agregados em que predominam filossilicatos e argilo-minerais (Fotomicrografia IV.29). 
llmenita subidiomórfica, com exsolução subordinada de hematita, é também o opaco primário típico e ocorre em cristais maiores isolados, por vezes esqueléticos, nos agregados máficos, e como inclusões menores em piroxênio e anfibólio. Pequenos cristais de calcopirita aparecem em algumas lâminas. Os acessórios típicos são zircão, apatita e chevkinita-perrierita; ocorrem isolados ou como inclusões em piroxênio, anfibólio e nas zonas marginais dos cristais de feldspato alcalino.

Minerais máficos tardi- a pós-magmáticos aparecem substituindo máficos primários ou, mais tipicamente em agregados intersticiais. Incluem, como no caso da fácies rósea, anfibólio actinolítico em cristais prismático idiomórficos ou agregados fibrosos, biotita idiomórfica a subidiomórfica com pleocroísmo em tons de bege-marron a vermelho, clorita, carbonatos, opacos (hematita, magnetita) e materiais mais finos não identificados.

Albita tardia ocorre como mantos parciais em feldspato alcalino ou intersticial, mais límpida e melhor geminada. É menos comum comparativamente às variedades róseas.

\section{IV.2.5 Sienitos róseos e verdes de granulação média}

São mineralogicamente equivalentes às variedades de granulação grossa descritas. Modalmente são álcali-feldspato sienitos e quartzo sienitos; as estruturas são maciças e as texturas mais tipicamente hipidiomórficas a xenomórficas, em geral equigranulares (Fotos IV.12 e IV.17). De forma geral os agregados intersticiais constituídos por minerais máficos tardi- a pós-magmáticos estão ausentes ou, pelo menos, são muito raros. A amostra Co-6E, inserida como pertencenteà fácies rósea de granulação média, apresenta características semelhantes às descritas anteriormente na fácies rósea de granulação grossa para a amostra Co-9A, ou seja intensa coloração marronavermelhada, oriunda de provável alteração hidrotermal (Foto IV.11).

As variedades de coloração verde são equigranulares, mas contêm ocasionalmente cristais tabulares mais desenvolvidos de feldspato alcalino (até $15,0 \mathrm{~mm})$. O feldspato alcalino $(1,0-3,0$ 
$\mathrm{mm}$ ) caracteriza-se pela maior quantidade de lamelas de albita pertítica; a albita intersticial tardia também é comum.

Quartzo é intersticial e xenomórfico, os intercrescimentos granofiricos são mais abundantes e aparecem intersticiais ou como bordas sobrecrescidas aos felspatos alcalinos. De forma geral, as quantidades de minerais máficos são menores, a olivina está tipicamente ausente e a biotita tardia é mais comum.

As características dos texturais e ópticas dos minerais máficos são similares. Destaca-se a maior abundância grãos corroídos de clinopiroxênio dentro de anfibólio e a maior quantidade de anfibólio cálcio-sódico, que também apresentam variações composicionais (Ca a $\mathrm{Ca}-\mathrm{Na}$ ) e inclusão de acessórios (Fotomicrografias IV.1, IV.6 e IV.7). Os minerais opacos e acessórios e suas relações texturais são similares, incluindo essencialmente ilmenita, zircão, chevkinita e apatita.

Uma variedade verde (amostra Co-3A) se destaca do conjunto por apresentar granulação pouco mais fina (fina a média), maior quantidade de minerais máficos e pelo aspecto geral "híbrido". A textura é mais tipicamente xenomórfica equigranular, os intercrescimentos granofíricos menos comuns e o feldspato alcalino $(0,5-2,0 \mathrm{~mm})$ exibe marcado zoneamento composicional; a geminação de Carlsbad é rara. A ilmenita aparece mais límpida, quase sem exsolução de hematita, e com alguma frequêencia encontra-se manteada por biotita castanha avermelhada. Adicionalmente, destaca-se a abundância de apatita acicular intercrescida com os demais minerais, particularmente feldspato alcalino e quartzo.

As variedades de coloração rósea por sua vez destacam-se adicionalmente das de coloração verde pela ausência de intercrescimentos granofíricos: o quartzo é predominantemente xenomórfico e intersticial. 


\section{IV.2.6 Sienitos róseos de granulação fina}

A par da granulação, são muito parecidos textural e mineralogicamente com as variedades róseas de granulação média. O maior contraste observado é a ausência ou a quantidade muito subordinada de biotita entre os minerais máficos, que ocorrem nestas rochas isoladamente ou como agregados glomerulares (Foto IV.13 e IV.14).

\section{IV.2.7. Melasienitos}

São álcali-feldspato sienitos (Figura IV.2) homogêneos com estrutura maciça e granulação média ou média a grossa, de aspecto muito fresco. Apresentam textura hipidiomórfica inequigranular de aspecto "cumulático", nestes casos com olivina, clinopiroxênio e minerais opacos como fases "cumuláticas" e feldspato alcalino e biotita como fases "inter-cumulus" mais típicas (Fotomicrografia IV.31, pág. 50). As quantidades modais de minerais máficos são bem elevadas (IC superior a 50) e tipicamente anfibólio e quartzo são fases ausentes.

O feldspato alcalino (2,0 a 10,0 mm) é subidiomórfico (cristais maiores) a xenomórfico. Os cristais menores não mostram em geral geminação e são freqüentemente intersticiais e límpidos, com pouca albita exsolvida, na forma de filmes muito finos.

O máfico mais abundante destas rochas é a olivina ferro-hortonolítica. Ocorre como cristais subidiomórficos a idiomórficos com dimensões entre 1,0 e $2,0 \mathrm{~mm}$, com $2 \mathrm{~V}_{\mathrm{x}}$ entre $45^{\circ}$ e $50^{\circ}$. Em geral encontra-se fraturada e apresenta intercrescimentos simplectíticos com diminutos cristai 3 de minerais opacos, em que parece predominar a ilmenita, além de finíssimos cristais de biotita (castanha-avermelhada) em suas bordas (Fotomicrografia $I V .30$ ).

$O$ clinopiroxênio também é abundante. Idiomórfico a subidiomórfico $(0,5-1,5 \mathrm{~mm}) \mathrm{em}$ geral límpido, opticamente não zonado. Corresponde a uma variedade salítica semelhante ao clinopiroxênio de primeira geração presente nas rochas sieníticas, com pleocroísmo muito 
incipiente em tonalidades róseas claras (Fotomicrografia IV.17). O ângulo $z^{\wedge} \mathrm{c}$ oscila entre $37^{\circ} \mathrm{e}$ $42^{\circ}$.

Biotita xenomórfica a subidiomórfica $(0,1-0,5 \mathrm{~mm})$ aparece sempre associada, em geral intersticial, aos minerais máficos e manteando-os. O pleocroísmo mostra cores que variam de castanho-avermelhada escuro a marron claro.

A fase opaca dominante é a ilmenita $(<2,0 \mathrm{~mm})$ que constitue cristais idiomórficos a esqueléticos de ocorrência isolada ou associada aos minerais máficos; às vezes como inclusões. Apresenta-se em geral límpida ou mais raramente como diminutas lamelas de exsolução de hematita. Ao contrário das rochas sieníticas mais típicas, os melasienitos apresentam, além de ilmenita, magnetita como fase primária, constituindo cristais idiomórficos ou esqueléticos, em geral límpidos, associados aos demais minerais máficos.

Apatita é o principal mineral acessório presente nestas rochas, ocorrendo como prismas curtos idiomórficos isolados ou inclusos em clinopiroxênio e mais raramente olivina.

\section{IV.2.8 Rochas dioriticas e hibridas}

São rochas de granulação fina a média, equigranulares, homogêneas com estrutura maciça. Modalmente correspondem a dioritos e quartzo dioritos; uma única amostra $(\mathrm{Co}-32 \mathrm{H})$ corresponde a um quartzo monzodiorito (Figura IV.2). Os minerais máficos típicos destas rochas são clinopiroxênio, anfibólio e biotita, observando-se nas amostras estudadas comportamento oposto entre anfibólio e biotita. Assim, nas amostras Co-45D e Co-22 predominam clinopiroxênio e biotita como máficos mais típicos, com pouco ou nenhum anfibólio; já nas demais amostras, em que o anfibólio é mais comum, com exceção do quartzo monzodiorito, a biotita é em geral bem menos abundante. 
As texturas são hipidiomórficas, a trama sendo dominada por cristais de plagioclásio tabulares a ripiformes, a maioria dos minerais máficos dispondo-se intersticialmente (Fotos IV.18, IV.19e IV.20).

O plagioclásio $(0,3-1,5 \mathrm{~mm})$ é idiomórfico ou subidiomórfico e apresenta geminação segundo as Leis da Albita, Carlsbad e, mais raramente, do Periclínio. Mostra zonamento composicional normal a oscilatório, com núcleos de andesina cálcica $\left(\mathrm{An}_{45-50}\right)$ a bordas de oligoclásio intermediário $\left(\mathrm{An}_{15-20}\right)$. Inclusões de clinopiroxênio e apatita são relativamente comuns, particulamente nas zonas marginais dos cristais. Alteração saussurítica é moderada a forte em algumas amostras (Fotomicrografia IV.28).

O feldspato alcalino, nos quartzo monzodioritos, aparece como cristais maiores subidiomórficos a xenomórficos $(0,5-1,5 \mathrm{~mm})$, pouco pertíticos, com geminação de Carlsbad. Alguns destes cristais ocasionalmente apresentam oligoclásio primário corroído nos núcleos (Fotomicrografia $I V .27$ ). Nas demais variedades é escasso e intersticial ou mesmo ausente. Quartzo $(<0,4 \mathrm{~mm})$ é intersticial, xenomórfico.

Clinopiroxênio, augítico, forma cristais subdiomórficos $(0,1-1,5 \mathrm{~mm})$, aparecendo como cristais individuais isolados ou em agregados máficos com anfibólio e biotita. Por vezes apresenta geminação simples e, nas variedades de granulação média, exibe bordas com aspecto corroído. Apresenta pleocroísmo incipiente em tonalidades rosadas claras e o ângulo $\mathrm{z}^{\wedge} \mathrm{c}$ é próximo de $40^{\circ}$ (Fotomicrografias IV.18 e IV.19).

$\mathrm{O}$ anfibólio idiomórfico a subidiomórfico $(<0,6 \mathrm{~mm})$ é uma variedade cálcica, com pleocroísmo em tons marron-esverdeados a verde-claro (Fotomicrografias IV.8 e IV.9). Em geral os cristais são opticamente homogêneos.

Biotita $(0,5-1,0 \mathrm{~mm})$ é xenomórfica a subidiomórfica, sendo melhor desenvolvidas nas variedades em que é mais abundante. Apresenta pleocroísmo bem marcado em tons de castanho claro a marrom avermelhado e com frequêencia mostra cristais tardios de prehnita ao longo dos 
planos de clivagem. Inclusões de minerais opacos são comuns (Fotomicrografias IV.20, IV.21 e IV.22).

Os minerais opacos incluem ilmenita e magnetita $(<1 \mathrm{~mm})$. Ambas aparecem como cristais idiomórficos ou esqueléticos isolados ou associados aos agregados máficos e também constituem inclusões nestes minerais. A ilmenita mostra exsolução e algumas bordas de hematita, enquanto a magnetita é mais límpida. Apatita idiomórfica, por vezes com hábito acicular é o acessório típico destas rochas, zircão é raro.

Os minerais de alteração, além da prehnita, incluem sericita, clorita, epidoto, carbonatos e opacos, associados à alteração do plagioclásio e/ou dos máficos primários.

\section{IV.2.9 Enclaves monzoníticos}

Entre os enclaves híbridos presentes nos sienitos róseos de granulação média, uma amostra mais homogênea, com coloração róseo acinzentada foi examinada ao microscópio petrográfico. Apresenta composição modal monzonítica (Figura IV.2) e textura mais ou menos equigranular hipidiomórfica, os minerais máficos aparecendo ora isolados, ora em agregados irregulares e, nestes casos, associados mais diretamente ao plagioclásio.

O plagioclásio $(0,5-2,5 \mathrm{~mm})$ é subidiomórfico, com hábito tabular e geminado pelas Leis da Albita e Carlsbad. Apresenta zonamento composicional normal a oscilatório no intervalo do oligoclásio, com teores de An variando entre 25 e 15 . Contém inclusões de clinopiroxênio, apatita e opacos.

O feldspato alcalino $(1,0-3,5 \mathrm{~mm})$ é em geral xenomórfico, pobremente geminado e contém quantidade reduzida de exsolução albítica na forma de finas lamelas. Os contatos entre os grãos e destes com os grãos de plagioclásio são sempre marcados por finas bordas albíticas mais límpidas. Apresenta inclusões de piroxênio, anfibólio, minerais acessórios e opacos, sempre mais 
abundantes nas bordas dos cristais. O quartzo $(<0,8 \mathrm{~mm})$ límpido é mais raro e aparece sempre intersticialmente aos feldspatos.

O clinopiroxênio $(0,1-1,5 \mathrm{~mm})$ é subidiomórfico a xenomórfico, augítico, com pleocroísmo incipiente em tons de rosa claro e $\mathrm{z}^{\wedge} \mathrm{c}$ próximo a $40^{\circ}$. Apresenta inclusões de minerais opacos e apatita e, com alguma freqüência, encontra-se manteado e/ou parcialmente substituído por anfíbólio e/ou biotita.

O anfibólio $(<1,5 \mathrm{~mm})$, do grupo da hornblenda, é subidiomórfico a idiomórfico é uma variedade cálcica e apresenta leve zonamento composicional, com pleocroísmo entre bege e marron claro esverdeado, passando para verde mais intenso nas bordas dos cristais (Fotomicrografia IV. IO). Ocorre isolado ou constitui agregados com biotita e minerais opacos.

A biotita $(0,1-2,0 \mathrm{~mm})$ é xenomórfica a subidiomórfica com cores variando de bege alaranjado a marron avermelhado (Fotomicrografia WV.23). Ocorre junto aos agregados máficos ou isoladamente, substituindo piroxênio e anfibólio e formando mantos irregulares sobre os minerais opacos primários.

Ilmenita com exsolução de hematita e magnetita $(<0,8 \mathrm{~mm})$ são as fases opacas dominantes, subidiomórficas. Apatita e zircão diminuto são os minerais acessórios, em geral aparecendo inclusos nos demais minerais. Os minerais de alteração incluem clorita que substitui anfibólio e biotita, prehnita sobre biotita, e materiais de sausurritização em plagioclásio. 


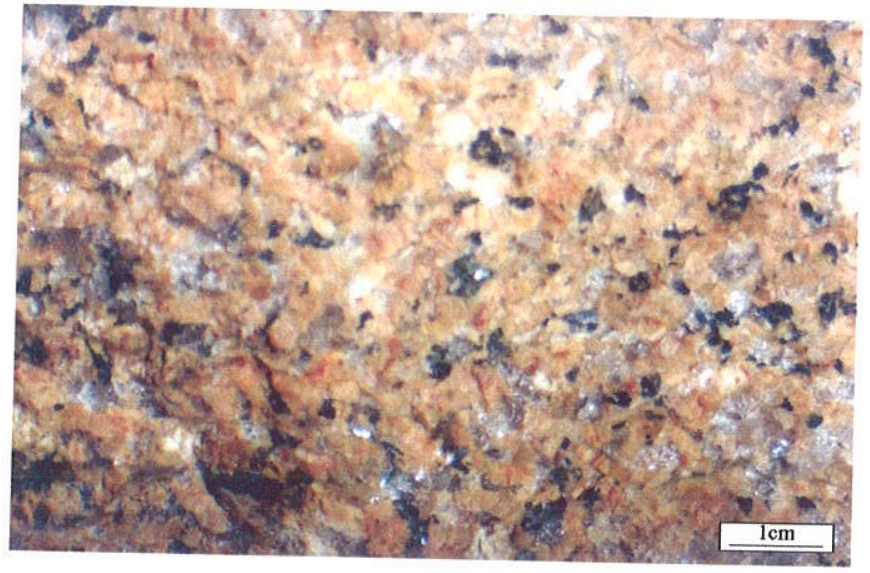

Foto IV.6. Detalhe da textura da fácies granitica de granulação média, destacando cristais de quartzo xenomórficos intersticiais. (Amostra Co-36) Lupa, sem filtro.

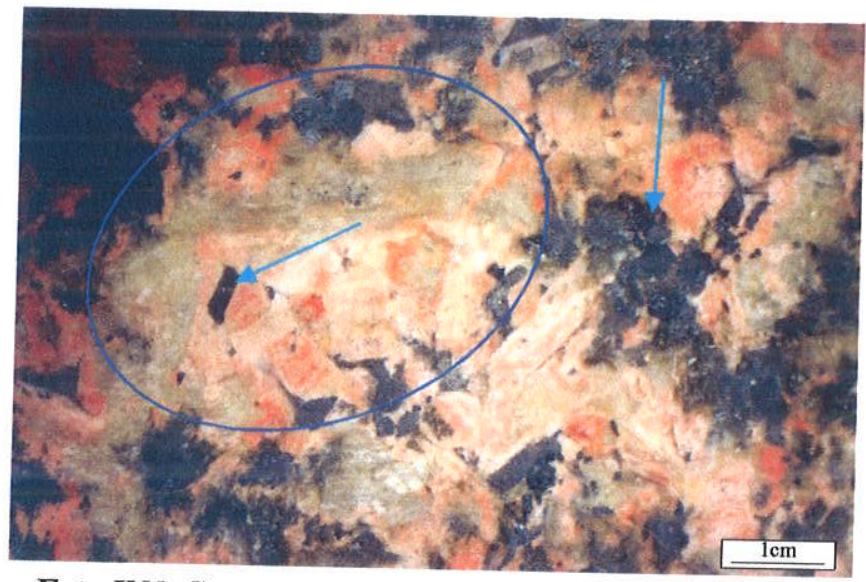

Foto IV.8. Sienito róseo grosso, destacado grande cristal de feldspato alcalino (indicado pelo circulo) e minerais máficos agregados e isolados (indicados pelas setas).

(Amostra Co-32A) Lupa, sem filtro.

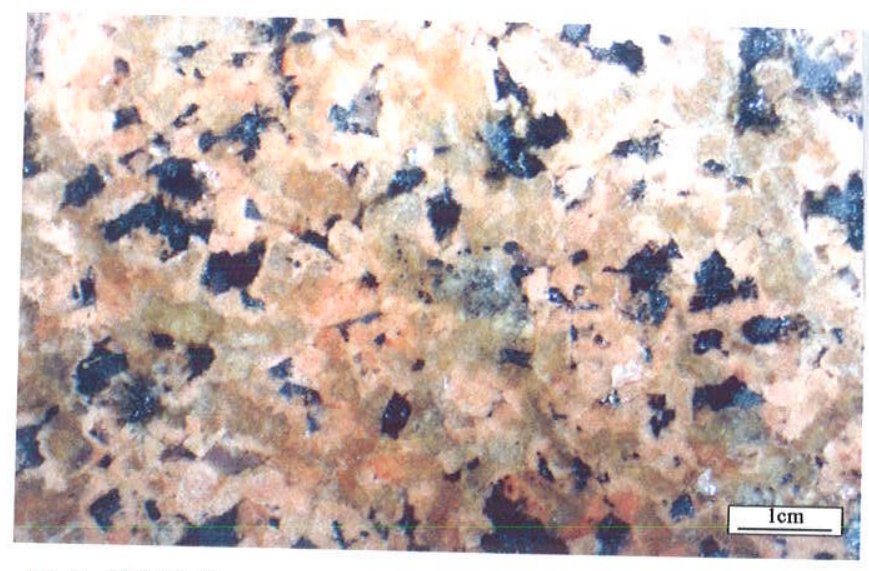

Foto IV.10. Sienito róseo grosso com IC aproximadamente 5.

(Amostra Co-35) Lupa, sem filtro.

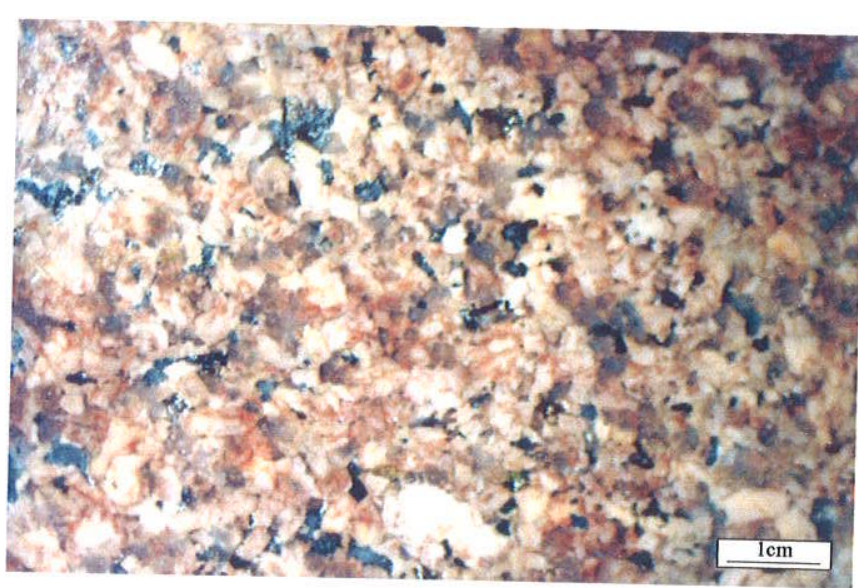

Foto IV.7. Granito de granulação média, comcristais de feldspato alcalino de coloração rosa um pouco mais intensa. (Amostra Co-2A) Lupa, sem filtro.

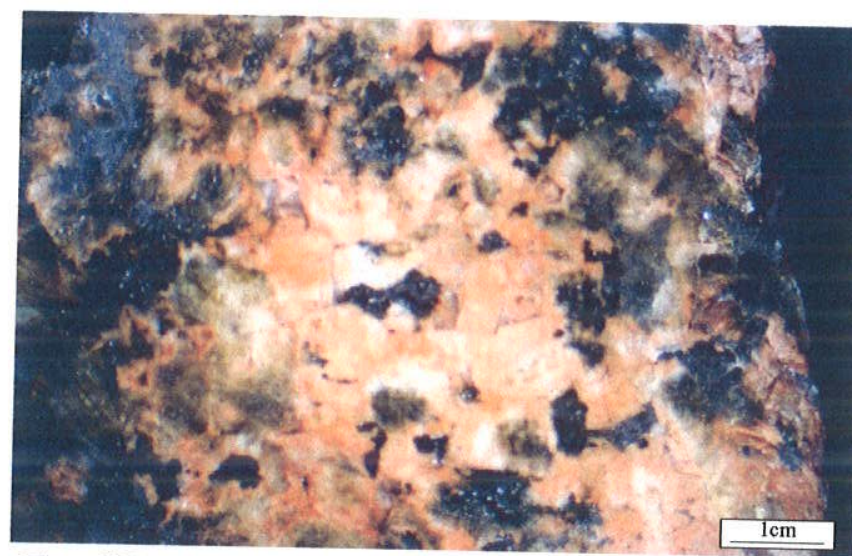

Foto IV.9. Sienito róseo grosso com IC aproximadamente 15.

(Amostra Co-32F) Lupa, sem filtro.

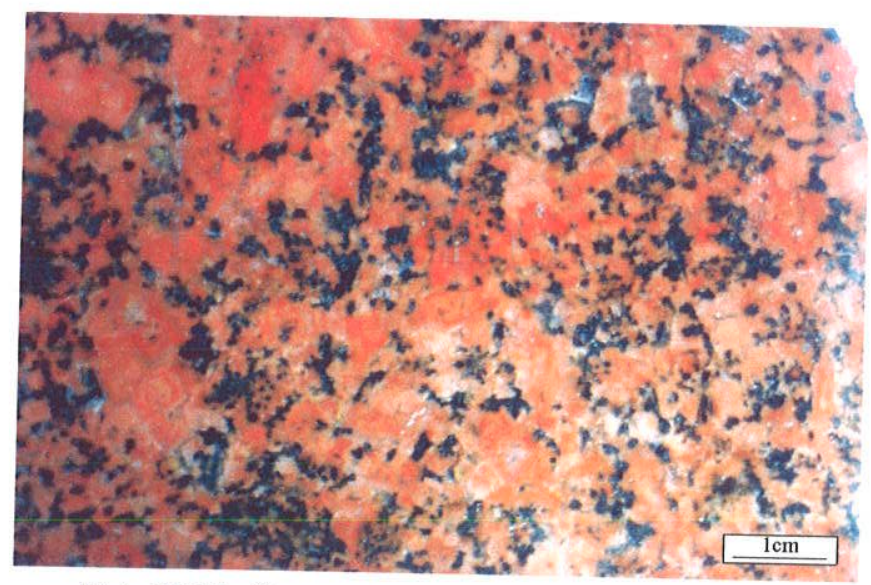

Foto IV.11. Sienito róseo médio, exibindo feldspato alcalino com intensa coloração vermelha intensa. (Amostra Co-6E) Lupa, sem filtro. 


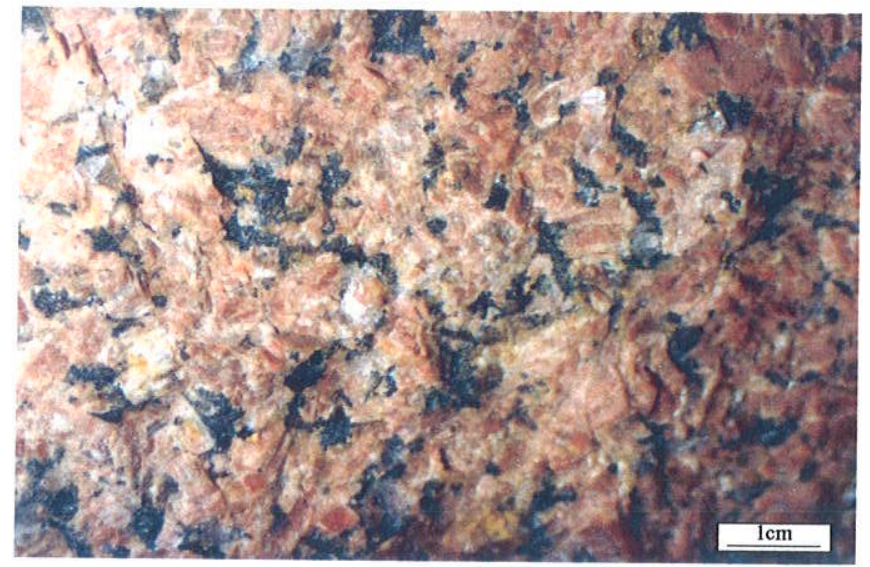

Foto IV.12. Detalhe do sienito róseo médio.. (Amostra Co-16C) Lupa, sem filtro.

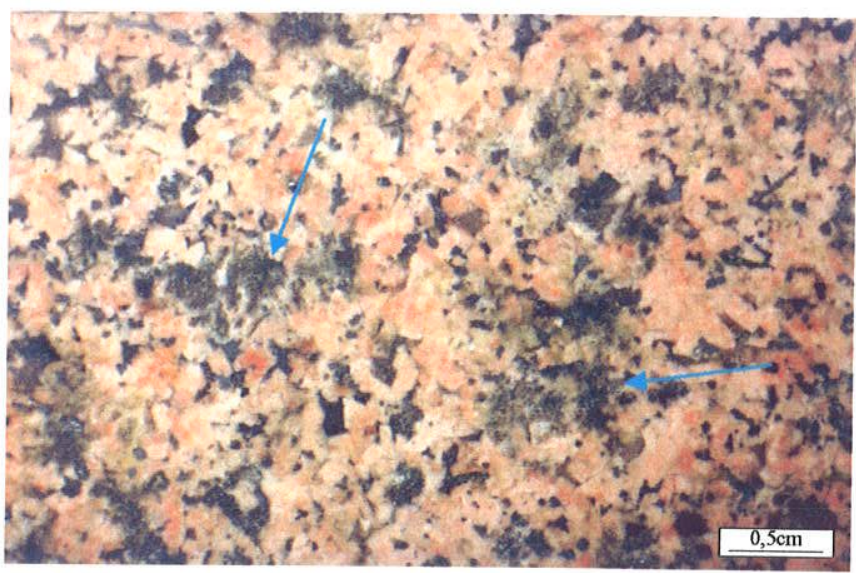

Foto IV.13 Sienito róseo fino, onde observa-se glomérulos máficos (indicados pelas setas) de composição. (Amostra Co-32B, Lupa, sem filtro.

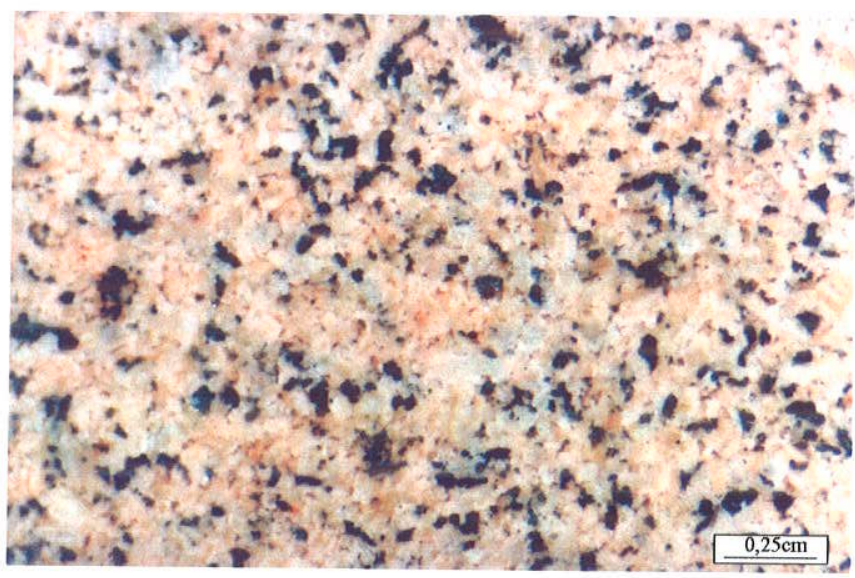

Foto IV.14. Sienito róseo fino com minerais máficos ocorrendo isoladamente.

(Amostra Co-32G) Lupa, sem filtro.

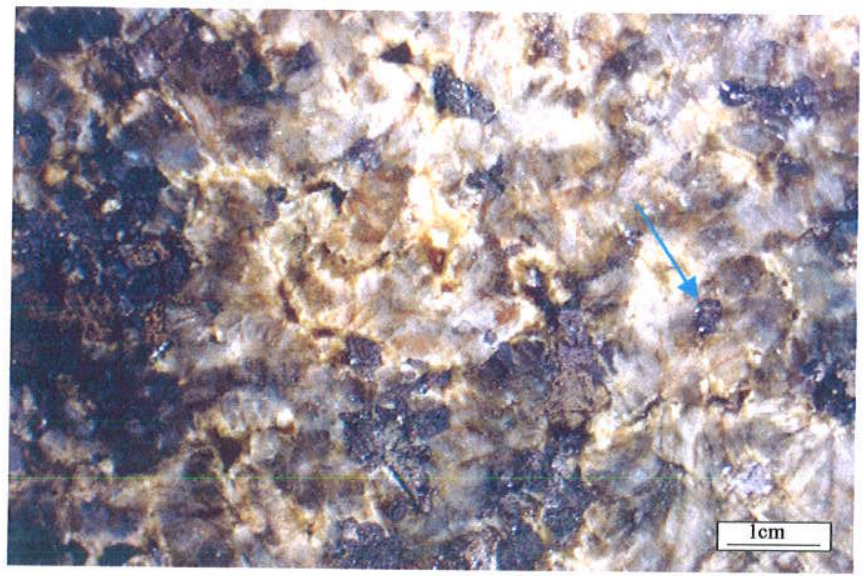

Foto IV.16. Sienito verde grosso, destacando cristal isolado de clinopiroxênio.

(Amostra Co-1) Lupa, sem filtro.

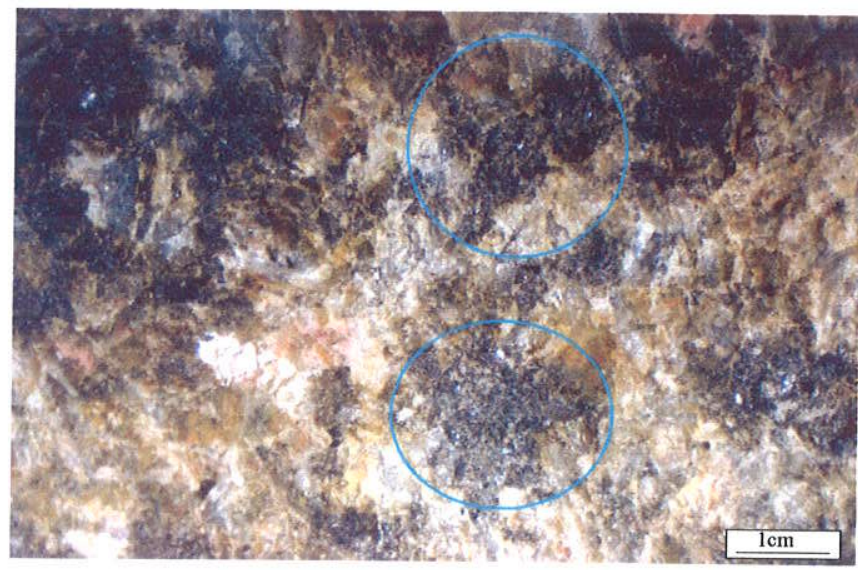

Foto IV.15. Sienito verde grosso, destacando glomérulos máficos (indicados pelos circulos). (Amostra Co-32C) Lupa, sem filtro.

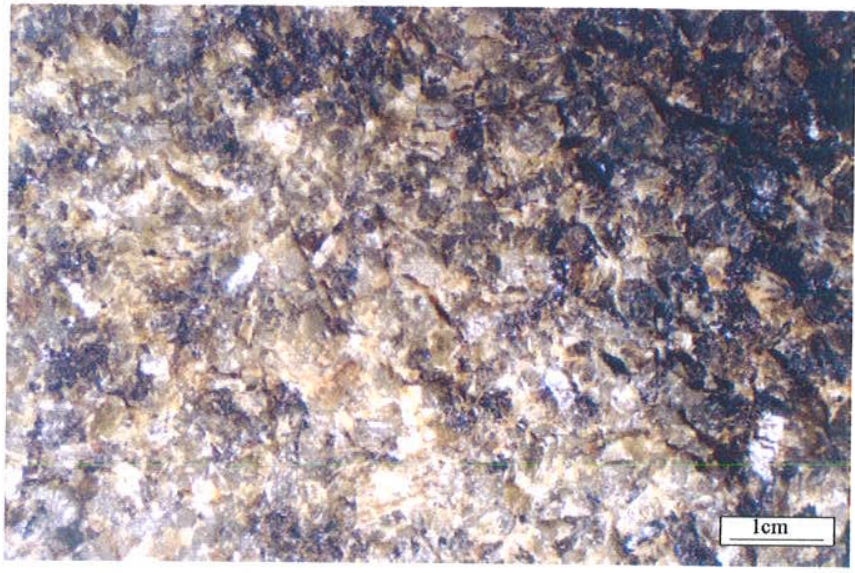

Foto IV.17. Sienito verde médio equigranular. (Amostra Co-5 Lupa, sem filtro. 


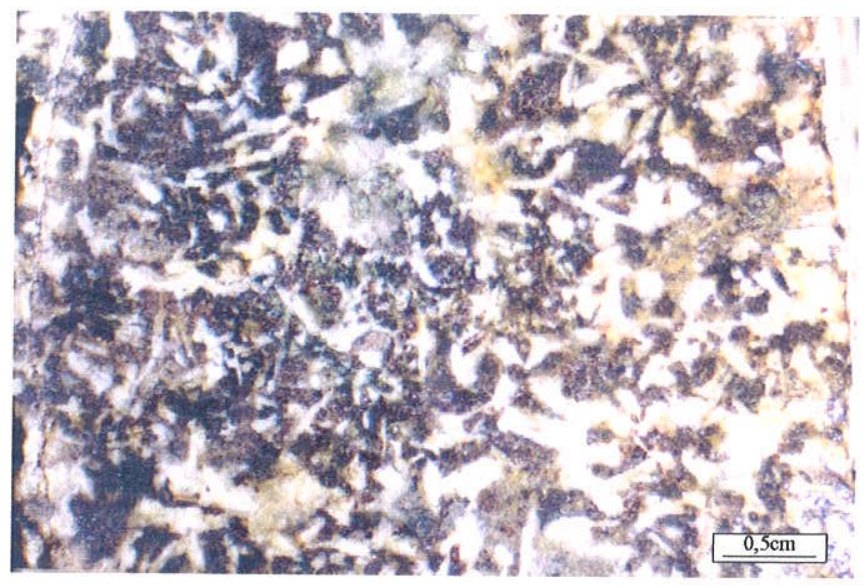

Foto IV.18. Detalhe do diorito médio, com cristais ripiformes de plagioclásio e minerais máficos intersticiais. (Amostra Co-50B) Lupa, sem filtro.

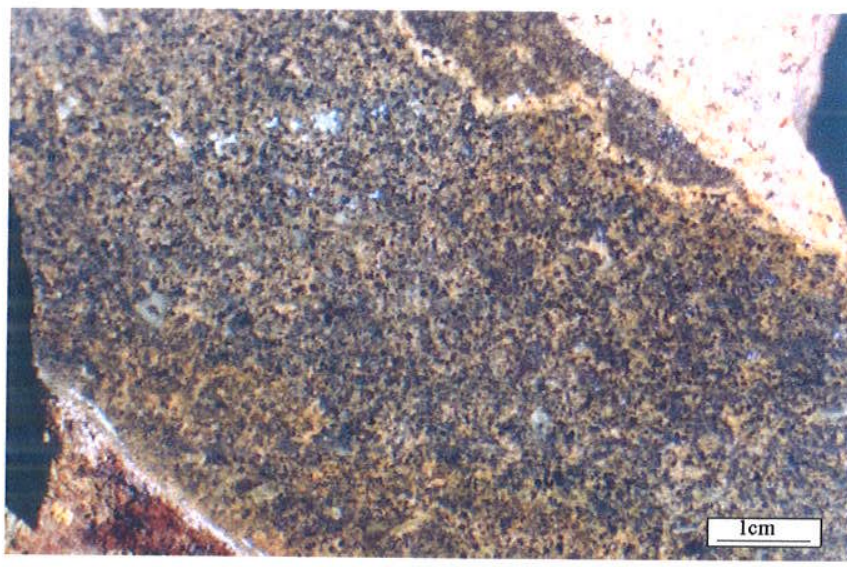

Foto IV.20. Rocha monzodiorítica de granulação fina em contanto com sienito róseo de granulação média. (Amostra Co-32C) Lupa, sem filtro.

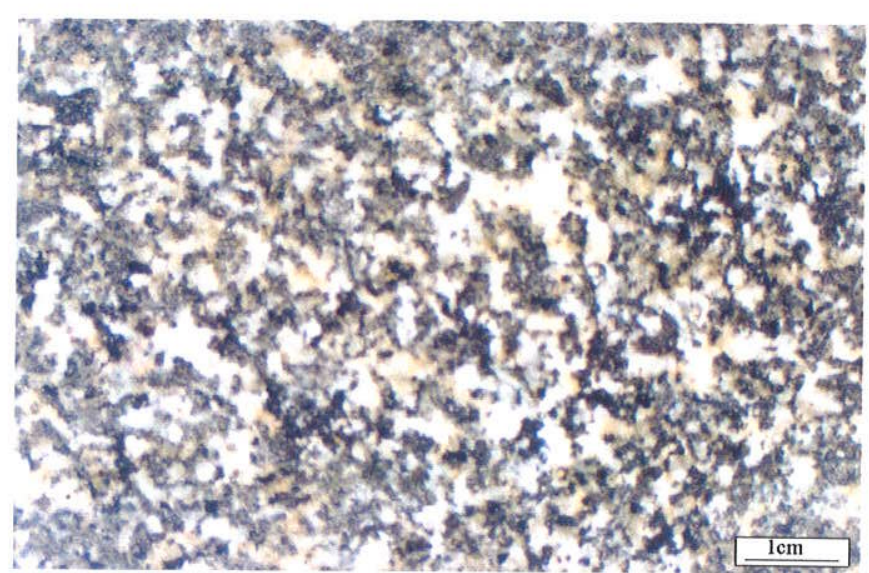

Foto IV.19. Diorito de granulação média, com minerais máficos itersticiais.

(Amostra Co-22) Lupa, sem filtro.

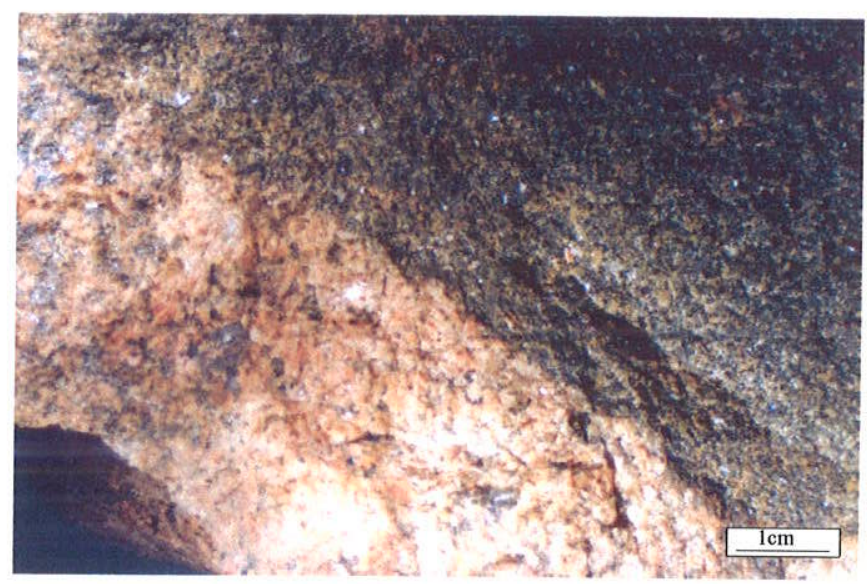

Foto IV.21. Detalhe do contato entre a rocha monzodiorítica e o sienito róseo médio.

(Amostra Co-32C) Lupa, sem filtro.

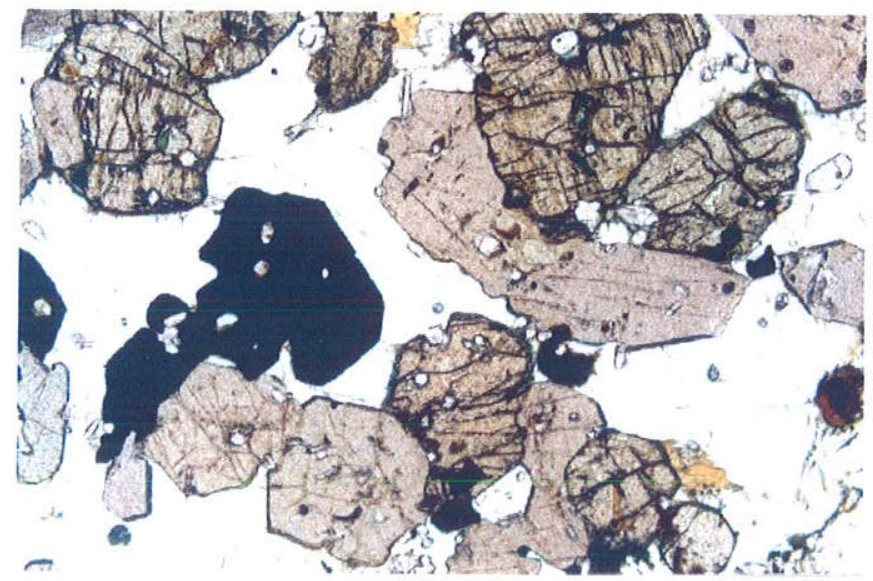

Fotomicrografia IV.31. Detalhe da textura cumulática do melasienito, com cristais "inter-cumulus" de feldspato alcalino (incolor) e cumulato de minerais máficos envolvendo olivina, clinopiroxênio, ilmenita, magnetita. Amostra Co-32D. Polarizador inferior, sem filtro, lado maior $8,0 \mathrm{~mm}$. 


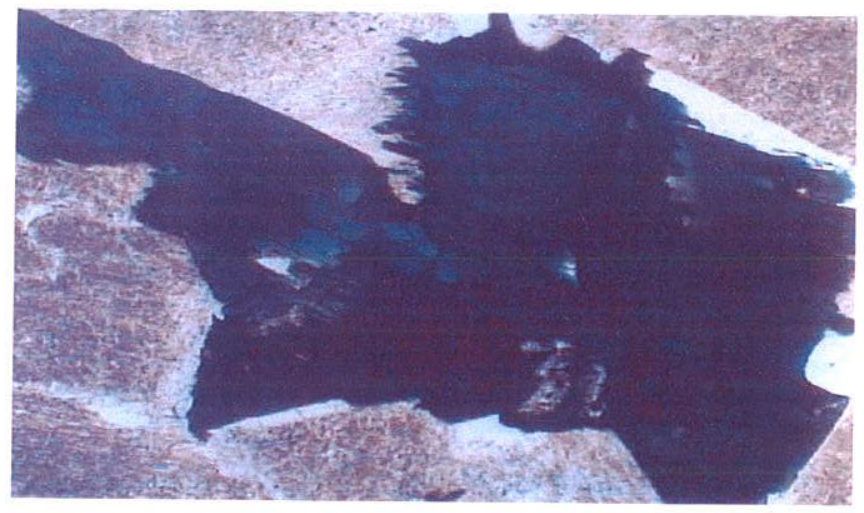

Fotomicrografia IV.1. Crsital subidiomórfico de anfibólio intersticial a feldspato alcalino com zonas cálcio-sódicas (mais escuras) a sódicas (com tons de azul escuro), com bordas esternas de anfibólio sódico em parte serrilhadas.

Em branco albita tardia. Fácies sienito róseo médio, amostra Co-38. Polarizador inferior, sem filtro. Lado maior da imagem $2,5 \mathrm{~mm}$.

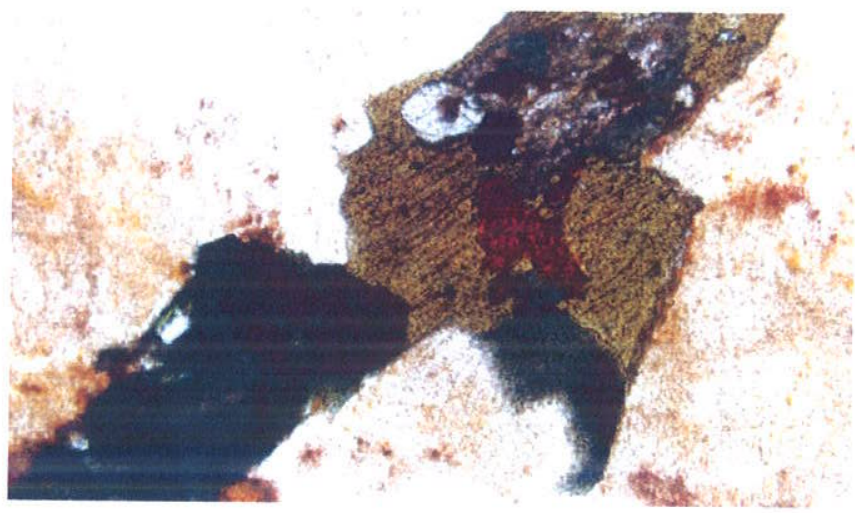

Fotomicrografia IV.3. Anfibólio cálcio-sódico com inclusão subidiomórfica de cristal de chevkinita (avermelhada). Fácies granito médio, amostra Co-36. Polarizador inferior, sem filtro. Lado maior da foto 1,0 $\mathrm{mm}$.

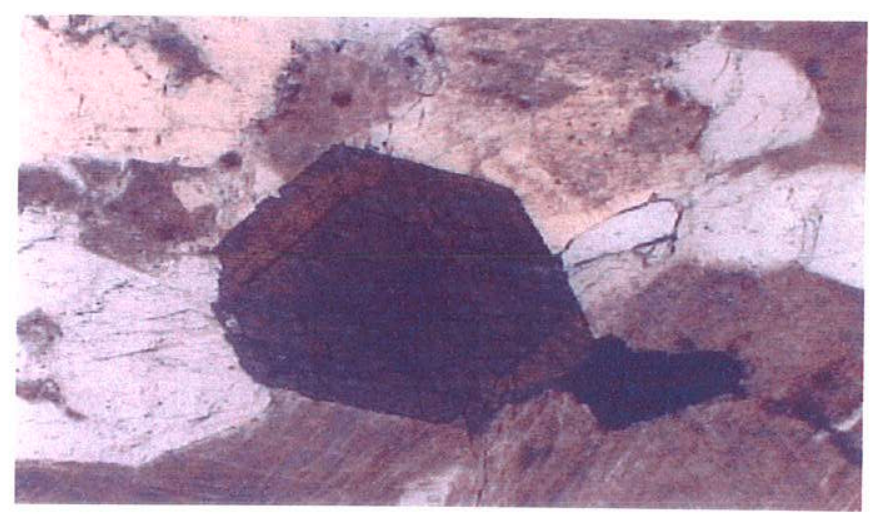

Fotomicrografia IV.2 Cristal idiomórfico de anfibólio ilustrando zonamento composicional normal de anfibólios cálcio-sódicos a sódicos, com núcleos em marrom mais escuro e bordas em marrom claro. Fácies granito médio, amostra Co-2A. Polarizador inferior, sem filtro. Lado maior da imagem $2,5 \mathrm{~mm}$.

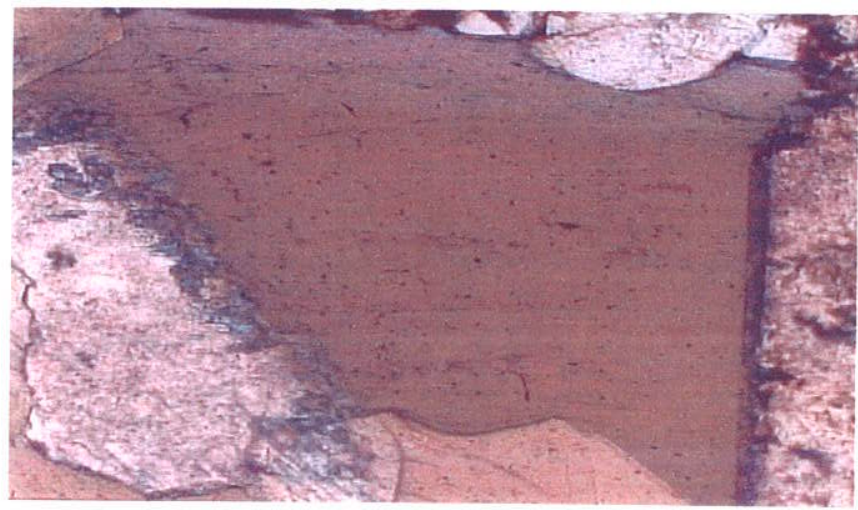

Fotomicrografia IV.4. Cristal de anfibólio cálcio-sódico com zonamento composicional da borda superior até a borda inferior. Fácies sienito róseo grosso, amostra Co32A. Polarizador inferior, sem filtro. Lado maior da imagem 1,0 $\mathrm{mm}$.

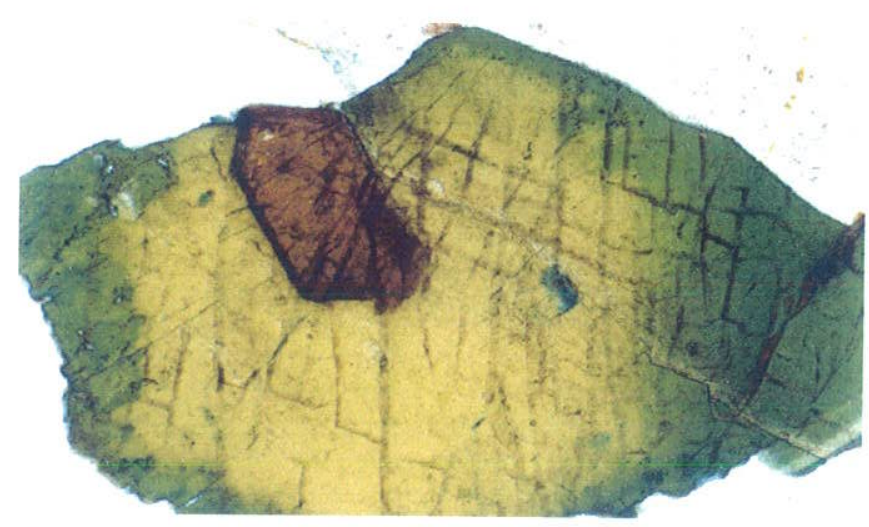

Fotomicrografia IV.6. Cristal idiomórfico de anfibólio com zonamento normal de núcleo cálcico para bordas cálcicosódicas, contendo inclusão idiomórfica de chevkinita em laranja. Fácies sienito verde médio, amostra Co-5. Polarizador inferior. Lado maior da foto 1,4 $\mathrm{mm}$. 


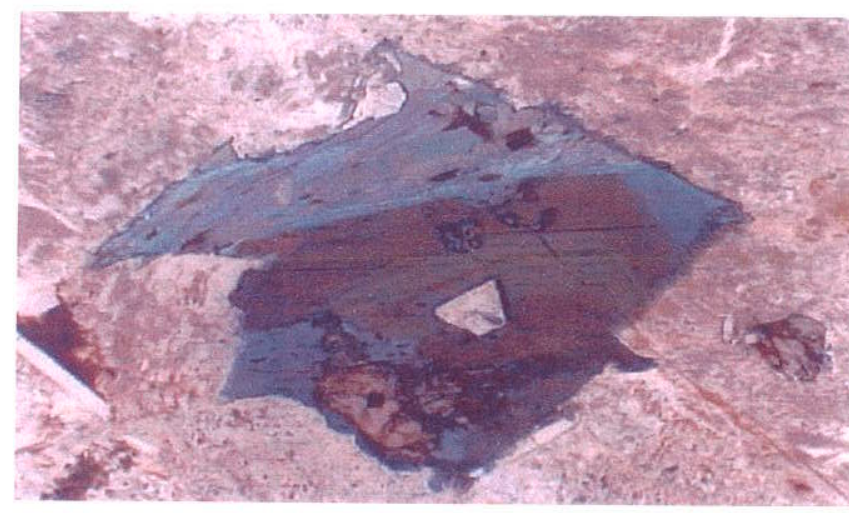

Fotomicrografia IV.7. Cristal subidiomórfico de anfibólio mostrando zonamento composicional de cálcico (centro, com cor marron-esverdeada) a cálcio-sódico (borda, com cor verde-azulada) em fácies sienito verde médio. Observar inclusão de apatita ou zircão no núcleo do anfibólio. Perto da borda inferior, cristal corroido de clinopiroxênio em marrom. Amostra Co-5. Polarizador inferior, sem filtro. Lado menor da imagem $2,5 \mathrm{~mm}$.

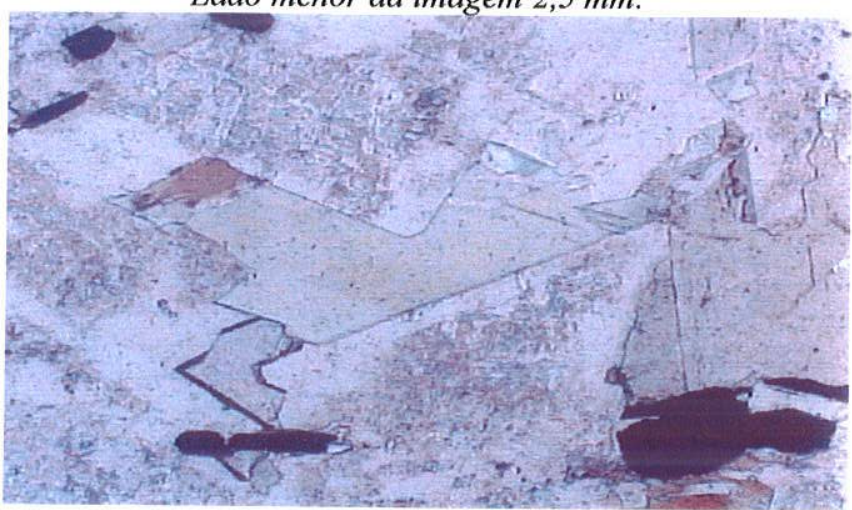

Fotomicrografia IV.9. Cristal de anfibólio cálcico com leve zonamento composicional. Observar cristal de fino cristal biotita na borda à esquerda do grão de anfibólio.

Fácies diorito fino, amostra Co-32H. Polarizador inferior, sem filtro, lado maior da imagem $1,0 \mathrm{~mm}$.

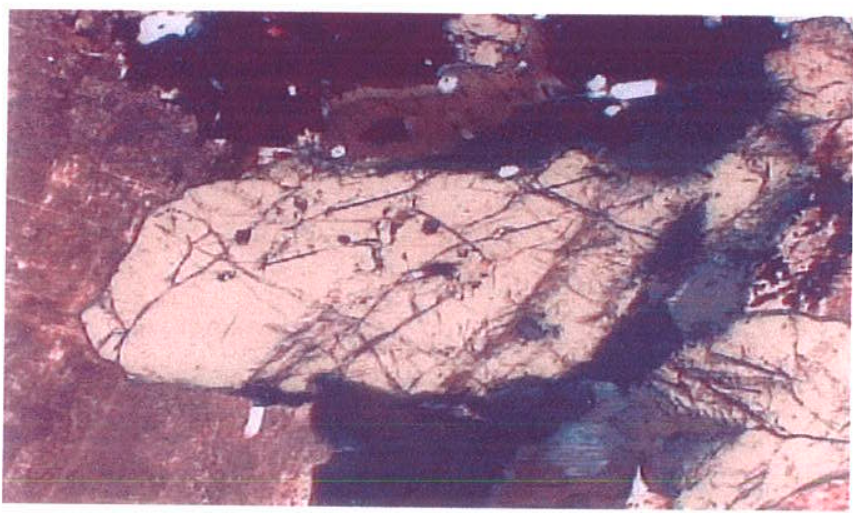

Fotomicrografia IV.11. Clinopiroxênio Ca (núcleo, rosado) a Ca-Na (bordas, verde-escuras). Observar cristais intersticiais de anfibólio à direita, além de inclusão de finissimos cristais de ilmenita. Fácies sienito róseo grosso, amostra Co-4B. Polarizador inferior, sem filtro, lado maior da imagem $3,4 \mathrm{~mm}$.

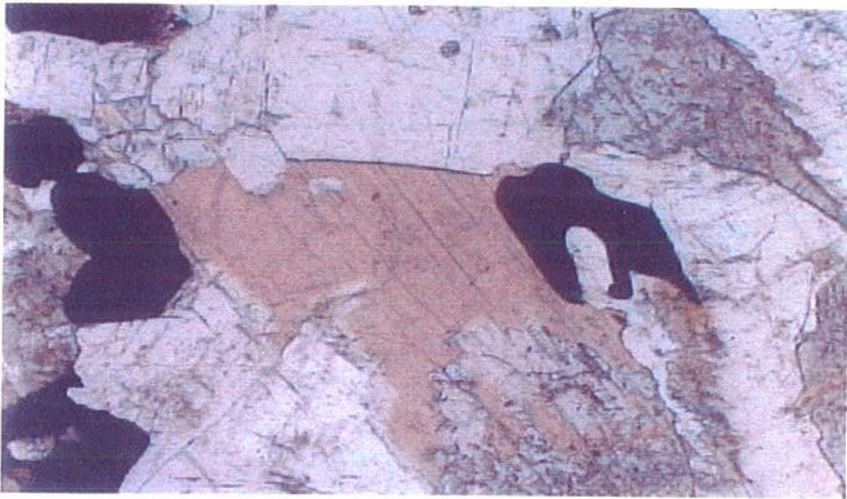

Fotomicrografia IV.8. Cristal subidiomórfico de anfibólio cálcico homogeneo em contato com plagioclásio, ilmenita (à direita) e magnetita (à esquerda), parcialmente incluindo apatita idiomórfica. Observar restos corroídos de piroxênio. Fácies sienito diorito médio, amostra Co-50B. Polarizador inferior, sem filtro, lado maior da imagem 2,5 $\mathrm{mm}$.

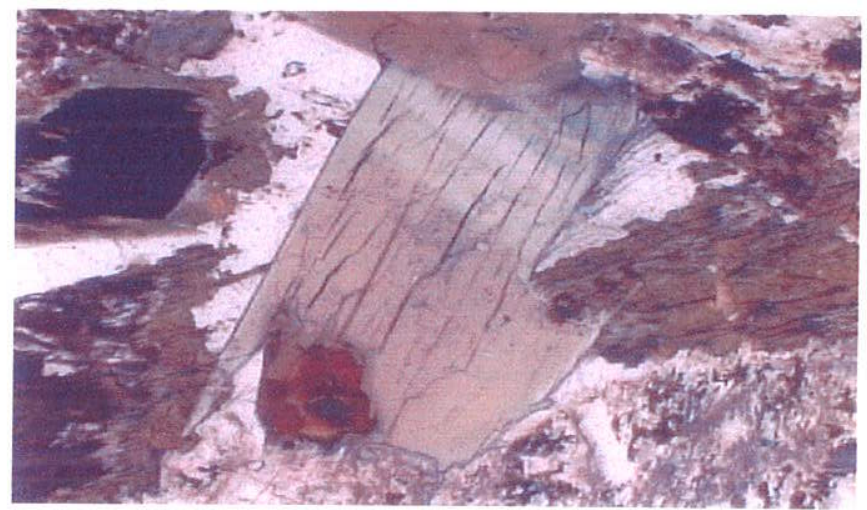

Fotomicrografia IV.10. Cristal de anfibólio subidiomórfico com zonamento composicional de cálcico (marron-clara) para cálcico-sódico (tonalidades de verde). Observar inclusão idiomórfica de chevkinita em laranja médio e suave halo pleocróico. Fácies sienito verde médio, amostra

Co-5. Polarizador inferior, sem filtro, lado maior da imagem 2,5 $\mathrm{mm}$.

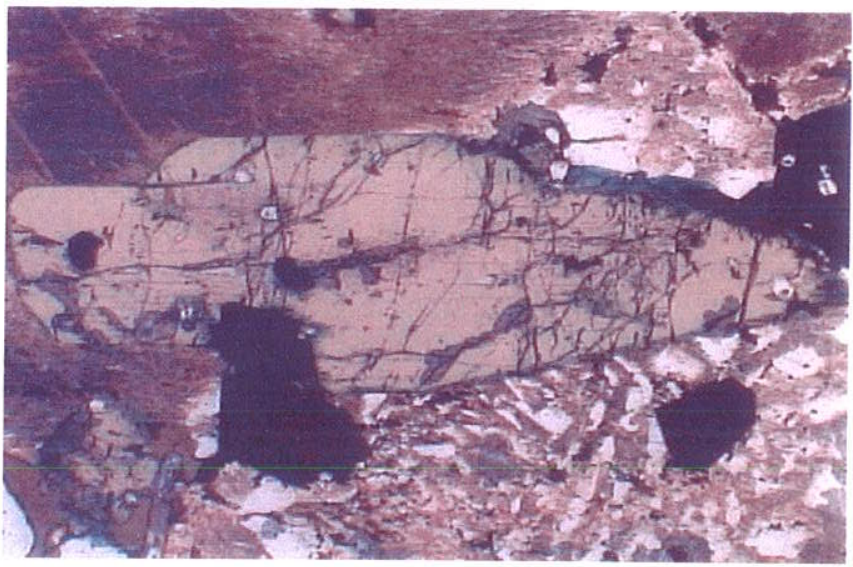

Fotomicrografia IV.12. Clinopiroxênio Ca (núcleo, róseo) a Ca-Na (bordas, verde -escuras).Fácies sienito róseo grosso, amostra Co-4B. Polarizador inferior, sem filtro, lado maior da imagem $3,4 \mathrm{~mm}$. 


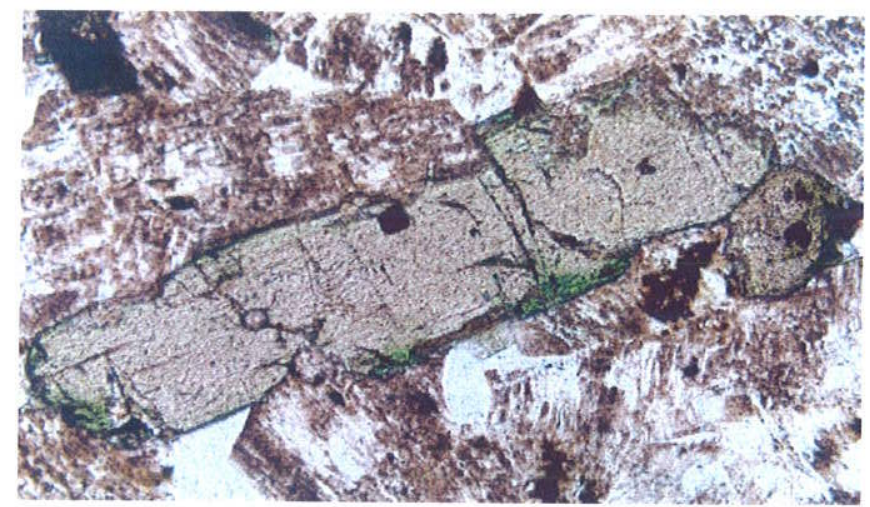

Fotomicrografia IV.13. Cristal de clinopiroxênio com pleocroísmo incipiente e bordas esverdeadas. Notar inclusão de pequenos cristais de zircão e ilmenita. Fácies sienito róseo grosso, amostra Co-40A. Polarizador inferior, sem filtro, lado maior da foto $2,5 \mathrm{~mm}$.

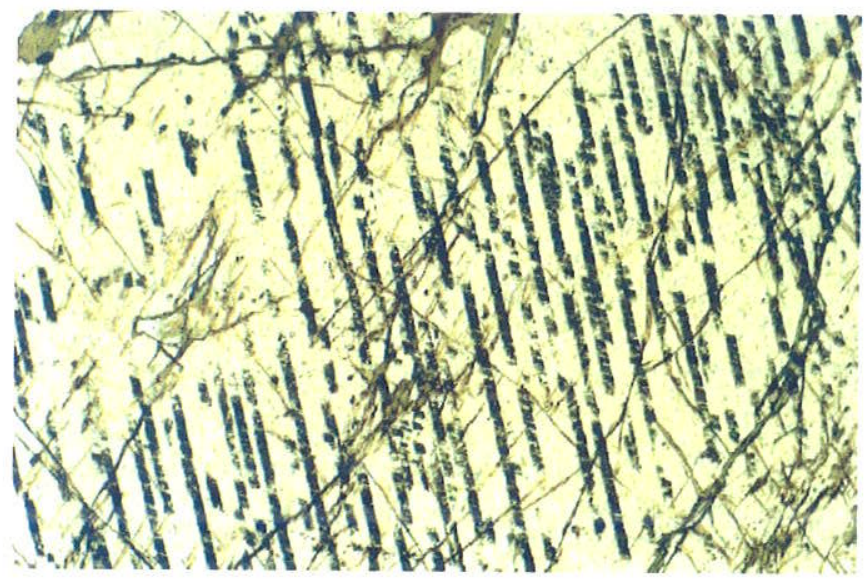

Fotomicrografia IV.15. Detalhe de minerais opacos inclusos ao longo dos planos de partição do clinopiroxênio.

Fácies sienito verde grosso, amostra Co-1. Polarizador inferior, sem filtro, lado maior da foto $1,4 \mathrm{~mm}$.

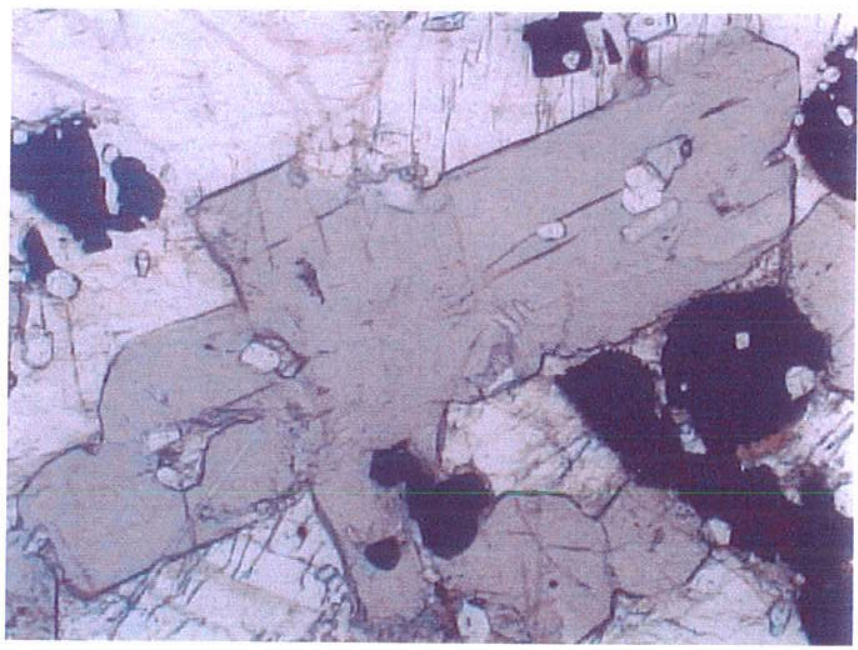

Fotomicrografia IV.17. Clinopiroxênio Ca, apresentando pleocroísmo incipiente. Observar cristais de apatita inclusos, além de magnetita e ilmenita (manteada por biotita) em contato. Fácies melsienito, amostra Co-32D. Polarizador inferior, sem filtro, lado maior da imagem 2,5 $\mathrm{mm}$.

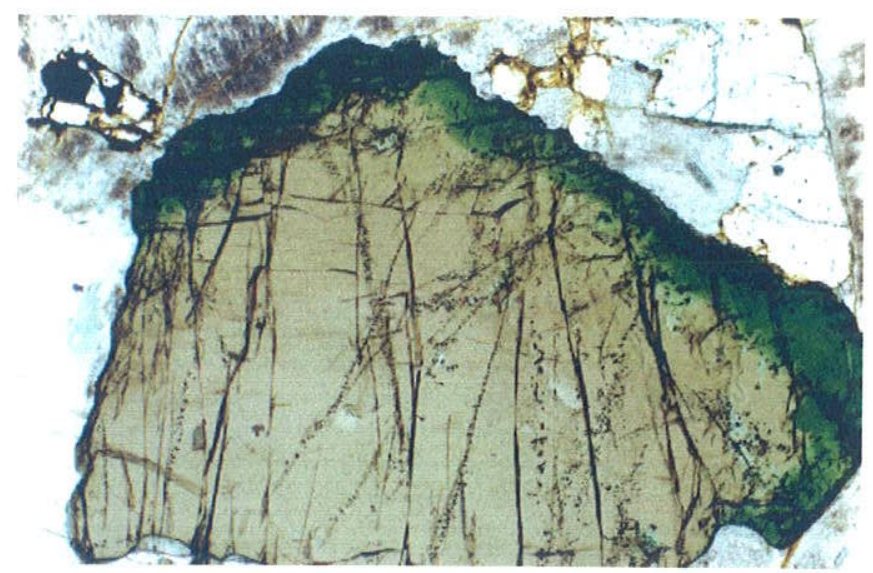

Fotomicrografia IV.14. Megacristal de clinopinoxênio Ca (regiões do núcleo e intermediárias, tonalidade rosa clara) a Ca-Na (bordas verde-escuras) subidiomórfico, apresentando borda parcialmente serrilhada. Fácies sienito verde grosso, amostra Co1. Polarizador inferior, sem filtro, lado maior foto $2,8 . \mathrm{mm}$.

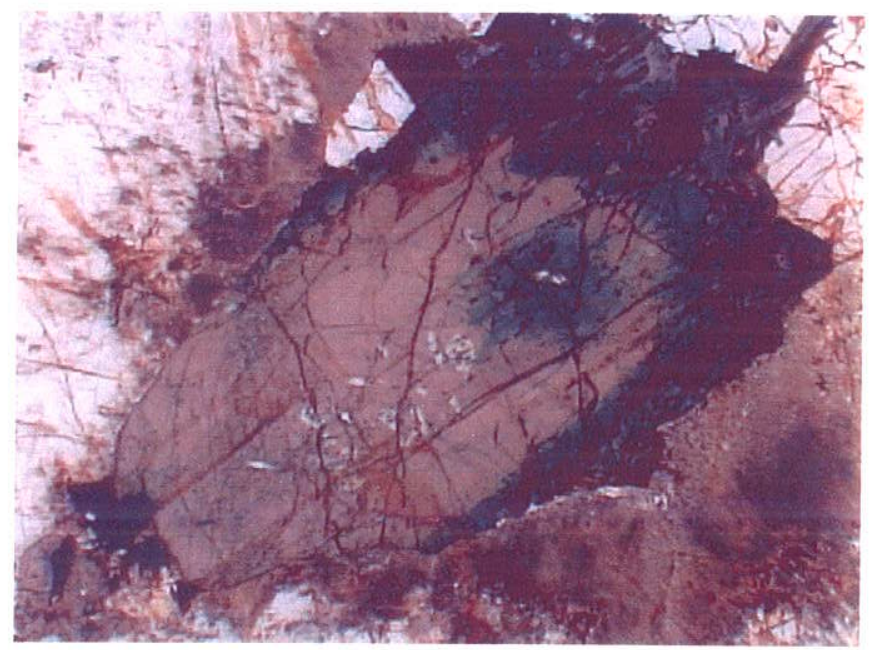

Fotomicrografia IV.16. Imagem de um megacristal zonado de clinopiroxênio, com inclusão de apatita. Fácies sienito verde grosso, amostra Co-1) Polarizador inferior, sem filtro, lado maior da imagem $8,0 \mathrm{~mm}$. Imagem vídeo-

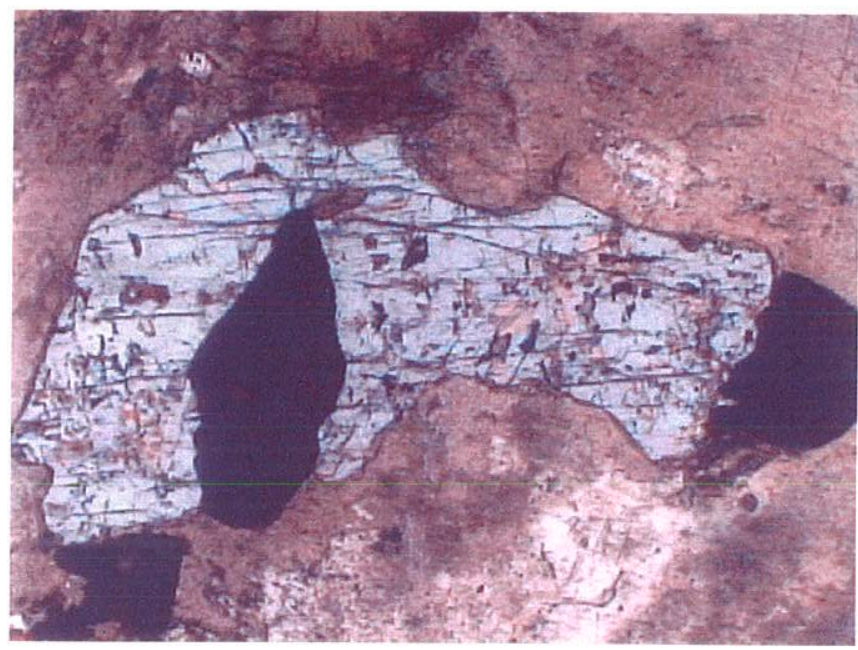

Fotomicrografia IV.18. Clinopiroxênio Ca, apresentando pleocroísmo incipiente e cristais de magnetita como inclusão e em contato. Fácies diorito médio, amostra Co22. Polarizador inferior, filtro azul, lado maior da imagem $2,5 \mathrm{~mm}$. 


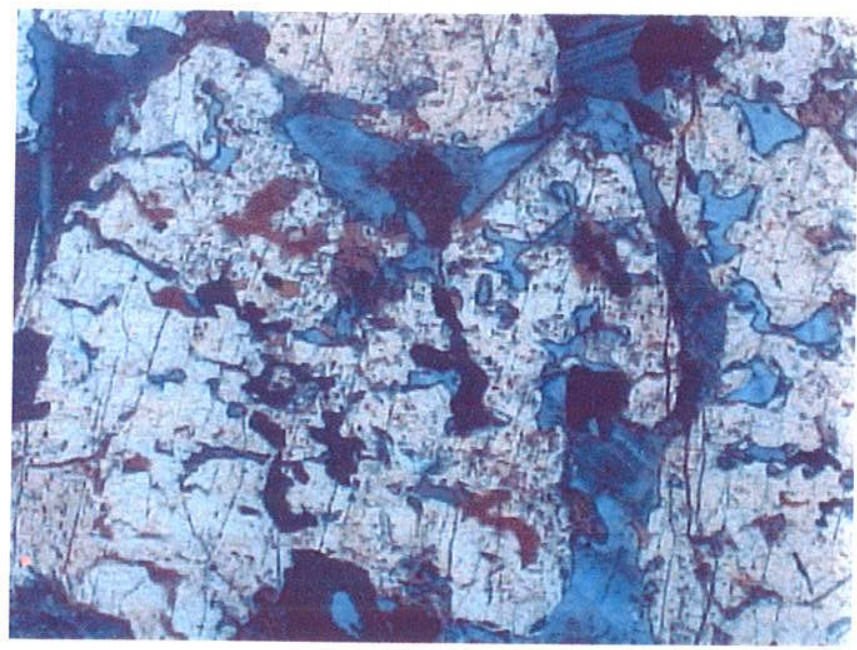

Fotomicrografia IV.19. Clinopiroxênio com bordas de aspecto corroído e pleocroísmo incipiente. Fácies diorito médio, amostra Co-50B. Polarizadores cruzados, sem filtro, lado maior da imagem $2,5 \mathrm{~mm}$.

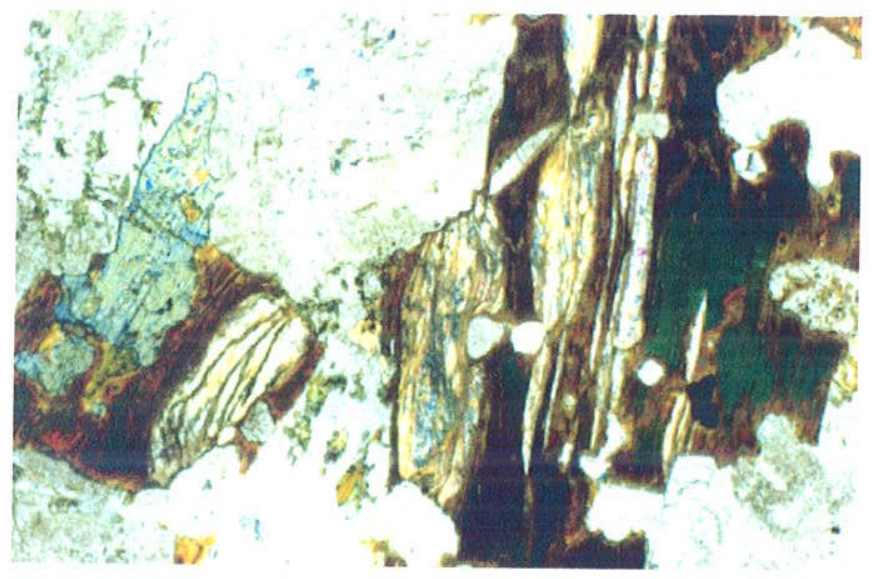

Fotomicrografia IV.21. Biotita de coloração verde praticamente substituida por cristais de prehnita. Fácies diorito médio, amostra Co-4D. Polarizador inferior, sem filtro, lado maior da foto $2,8 \mathrm{~mm}$.

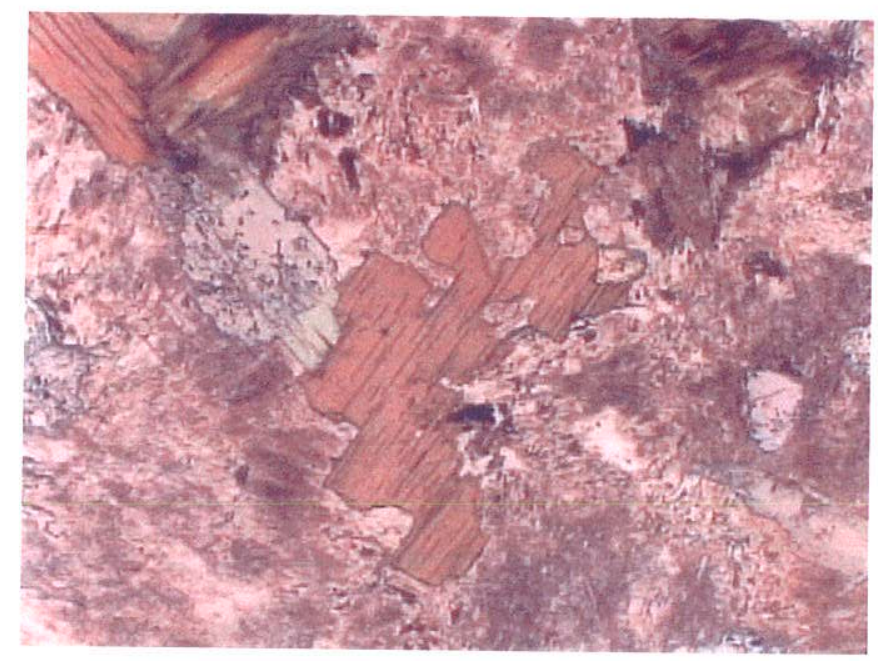

Fotomicrografia IV.23. Biotita subidiomórfica em contato com pseudomorfo de anfibólio em sua borda esquerda. Fácies enclave monzonítico, amostra Co-6C. Polarizador inferior, sem filtro, lado maior da imagem $2,5 \mathrm{~mm}$.

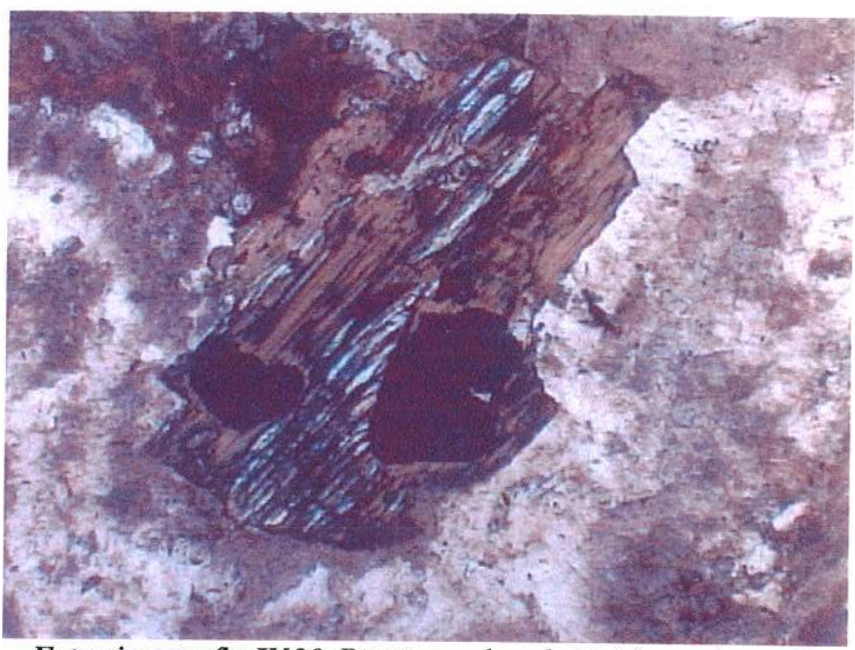

Fotomicrografia IV.20. Biotita sendo substituida, ao longo de seus planos de clivagem, por cristais de prehnita, contendo também inclusões de cristais de magnetita e apatita inclusos.

Fácies diorito médio, amostra Co-22. Polarizador inferior, sem filtro, lado maior da imagem $2,5 \mathrm{~mm}$

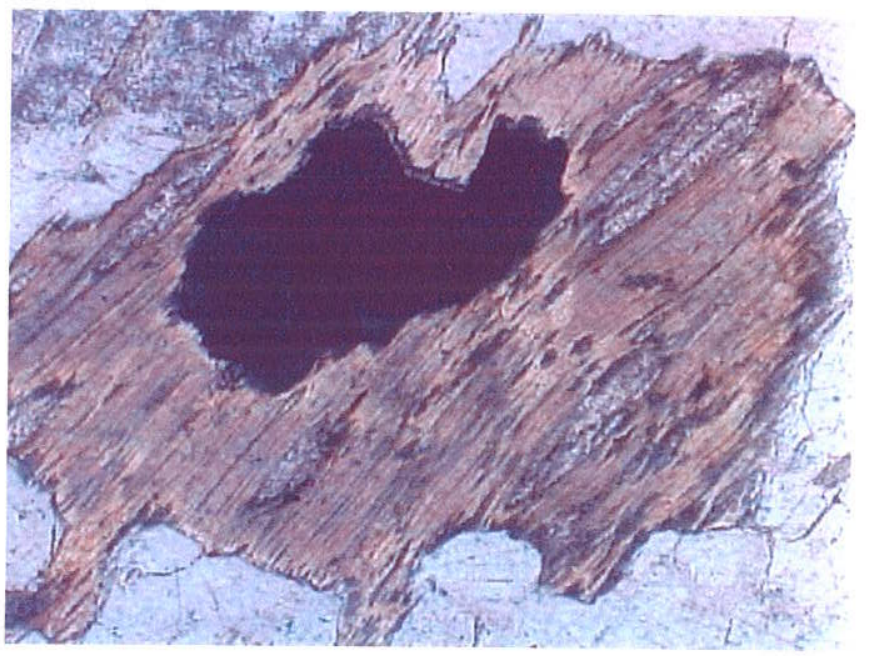

Fotomicrografia IV.22. Biotita sendo substituída, ao longo de seus planos de clivagem, por cristais de prehnita. Cristal médio de magnetita incluso. Fácies diorito médio, amostra

Co-50B. Polarizador inferior, sem filtro, lado maior da

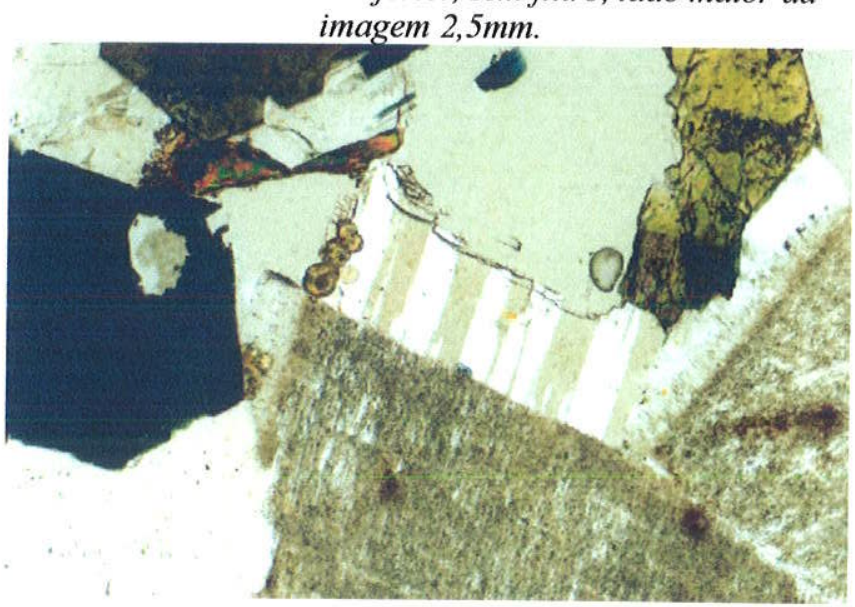

Fotomicrografia IV.24. Feldspato alcalino (aspecto sujo) com albita geminada em sua borda. À esquerda da foto cristal de ilmenita. Na parte centro-superior cristal límpido de quartzo e mais à esquerda, cristal de anfibólio intersticial. Fácies granito médio, amostra Co-2A. Polarizador inferior, sem filtro, lado maior da foto $1,4 \mathrm{~mm}$. 


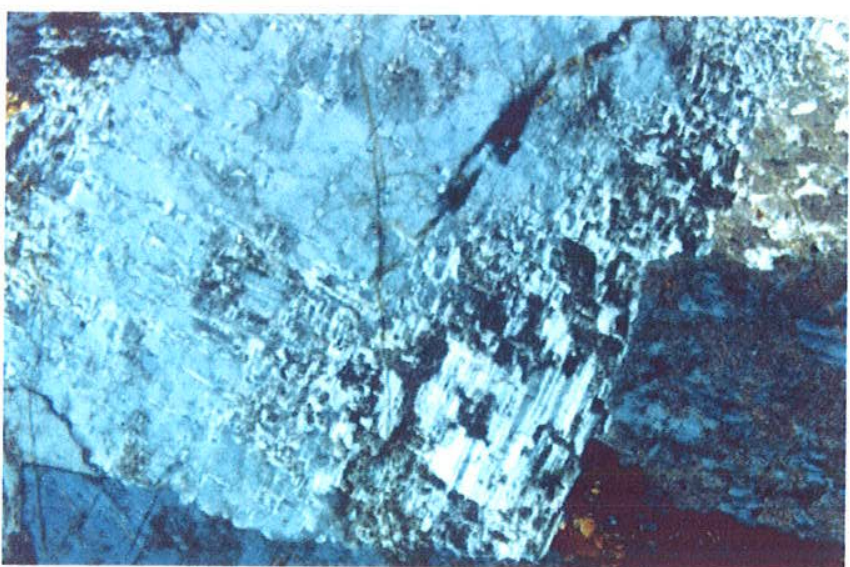

Fotomicrografia IV.25. Feldspato alcalino com exsolução de albita tipo "chessboard". Fácies sienito róseo grosso, amostra Co-32A. Polarizadores cruzados, sem filtro, lado maior foto $1,0 \mathrm{~mm}$.

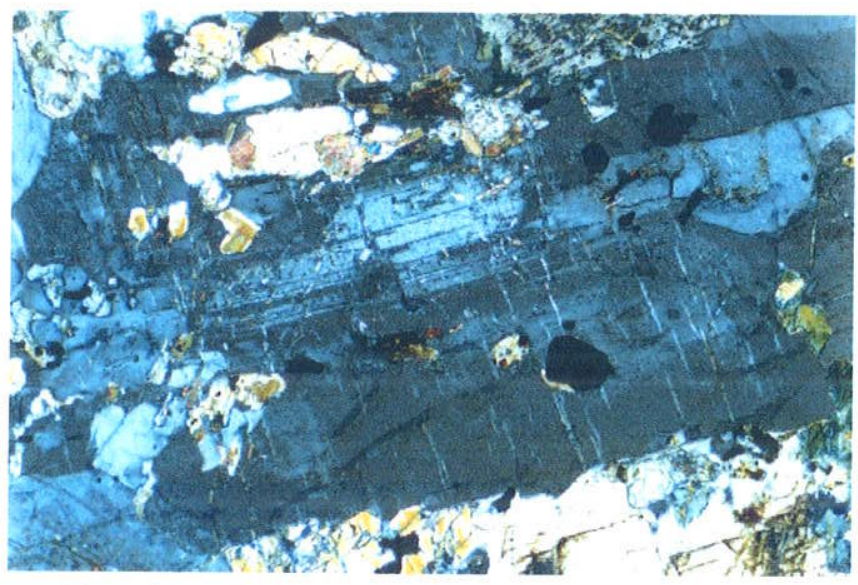

Fotomicrografia IV.27. Cristal de feldspato alcalino, contendo núcleo corroído de plagiclásio primário. Fácies hibrida, amostra Co-3A. Polarizadores cruzados, sem filtro, lado maior foto $1,4 \mathrm{~mm}$.

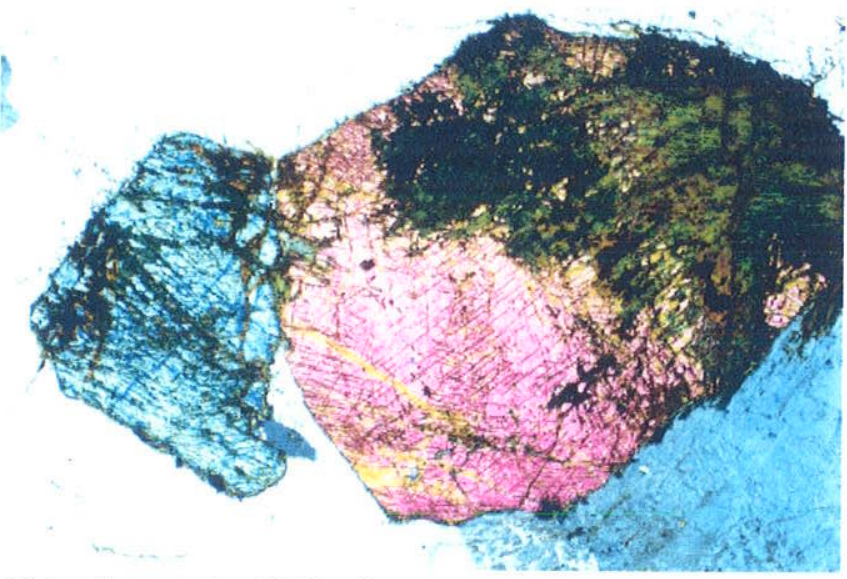

Fotomicrografia IV.29. Cristais microfaturados de olivina .O cristal maior apresenta-se parcialmente substiuido por agregado de minerais secundários. Fácies sienito verde grosso, amostra Co-1. Polarizadores cruzados, sem filtro, lado maior $5,5 \mathrm{~mm}$.

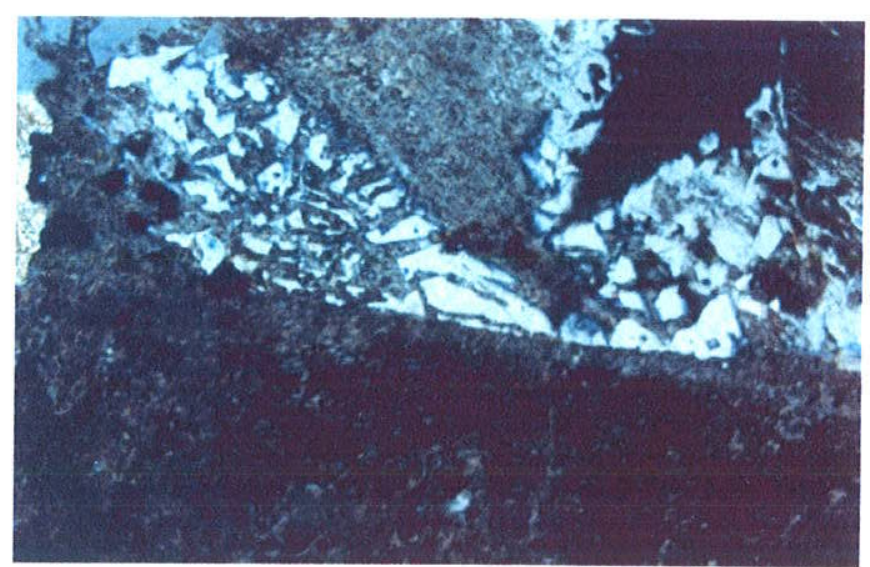

Fotomicrografia IV.26. Textura de intercrescimento microgranofirico entre quartzo e feldspato alcalino. Fácies sienito róseo grosso, amostra Co-32B. Polarizadores cruzados, sem filtro, lado maior da foto $2,5 \mathrm{~mm}$.

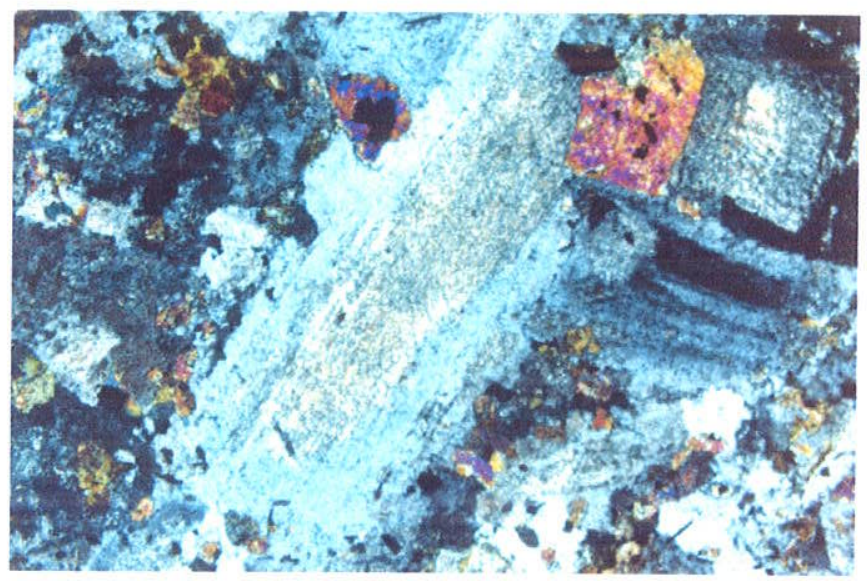

Fotomicrografia IV.28. Plagioclásio ripiforme com núcleo bastante alterado, incluindo pequenos cristais de clinopiroxênio. Fácies diorito fino, amostra Co-34B. Polarizadores cruzados, sem filtro, lado maior da foto $2,5 \mathrm{~mm}$.

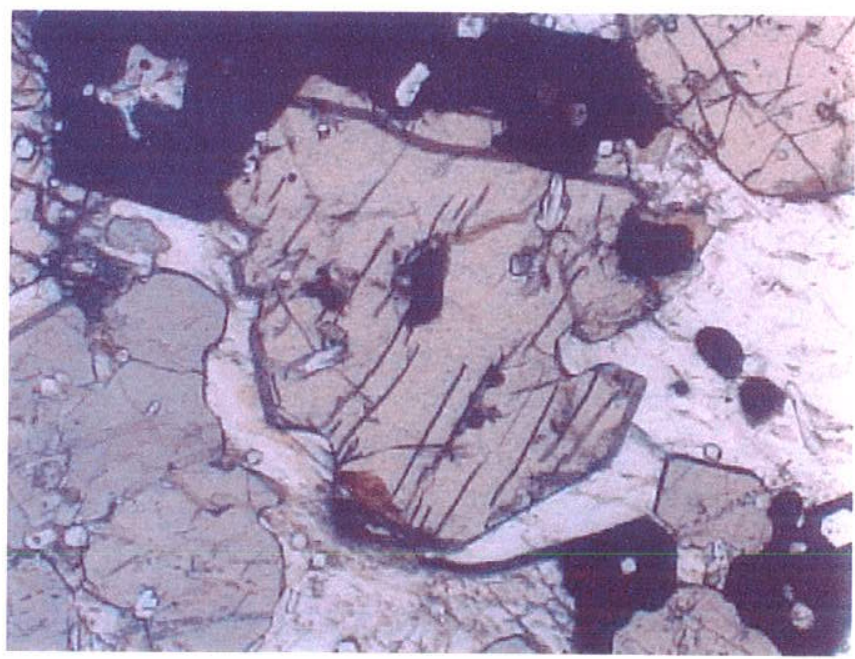

Fotomicrografia IV.30. Olivina microfraturada incluindo cristais de ilmenita e magnetita, além de fina borda de biotita em sua borda na parte inferior. Fácies melasienito, amostra Co-32D. Polarizador inferior, sem filtro, lado maior $2,5 \mathrm{~mm}$. 


\section{IV.3. As modas das rochas do Maciço Corupá}

As tendências modais de variação das rochas mapeadas no Maciço Corupá permitem tecer algumas considerações gerais, a ser exploradas futuramente com dados químicos mais elaborados.

De uma forma geral, a tendência de variação modal no conjunto de rochas estudado é compatível com a denominada série alcalina supersaturada conforme sugerido por Lameyre \& Bowden (1982) (Figura IV.2; Tabela IV.2). Entretanto, os dados obtidos para o maciço sugerem uma associação contrastada entre as rochas sieníticas e graníticas por um lado e as rochas dioríticas por outro. As rochas de composição intermediária (monzodioríticas e monzoníticas) são raras e quando encontradas aparecem em geral como enclaves que evidenciam processos de hibridismo entre magmas originalmente dioríticos e sieníticos, como é o caso mais típico dos enclaves monzoníticos encontrados.

As rochas sieníticas e graníticas não apresentam plagioclásio como fase primária magmática, sendo tipicamente rochas "hipersolvus" na concepção de Tuttle \& Bowen (1958). Adicionalmente, os melasienitos, as rochas sieníticas mais máficas encontradas no maciço, também não contêm plagioclásio.

Assim, no Maciço Corupá parece não existir uma "série de diferenciação" no sentido clássico com termos mais máficos que por cristalização fracionada evoluem para rochas intermediárias e finalmente félsicas. Pelo contrário, as evidências sugerem a coexistência parcial de magmas dioríticos e sieníticos contrastados que apenas localmente interagiram resultando nas rochas híbridas de composições intermediárias, conforme exposto na literatura internacional por Bonin et al. (1998), Anderson (1983) e, no caso da Província Serra do Mar, Gualda (2001).

Os dados obtidos sugerem também uma certa lacuna modal entre as rochas sieníticas e graníticas (Figura $I V .2$ ). Se esta for de fato real e não um artifício de amostragem, poderia também sugerir magmas originalmente contrastados ou, alternativamente, que se estas rochas foram originadas a partir do mesmo magma parental, em algum momento uma certa fração de 
liquidus granítico, a partir de "mushes" sieníticos, foi extraída e individualizada, o que representa uma hipótese mais atraente. 


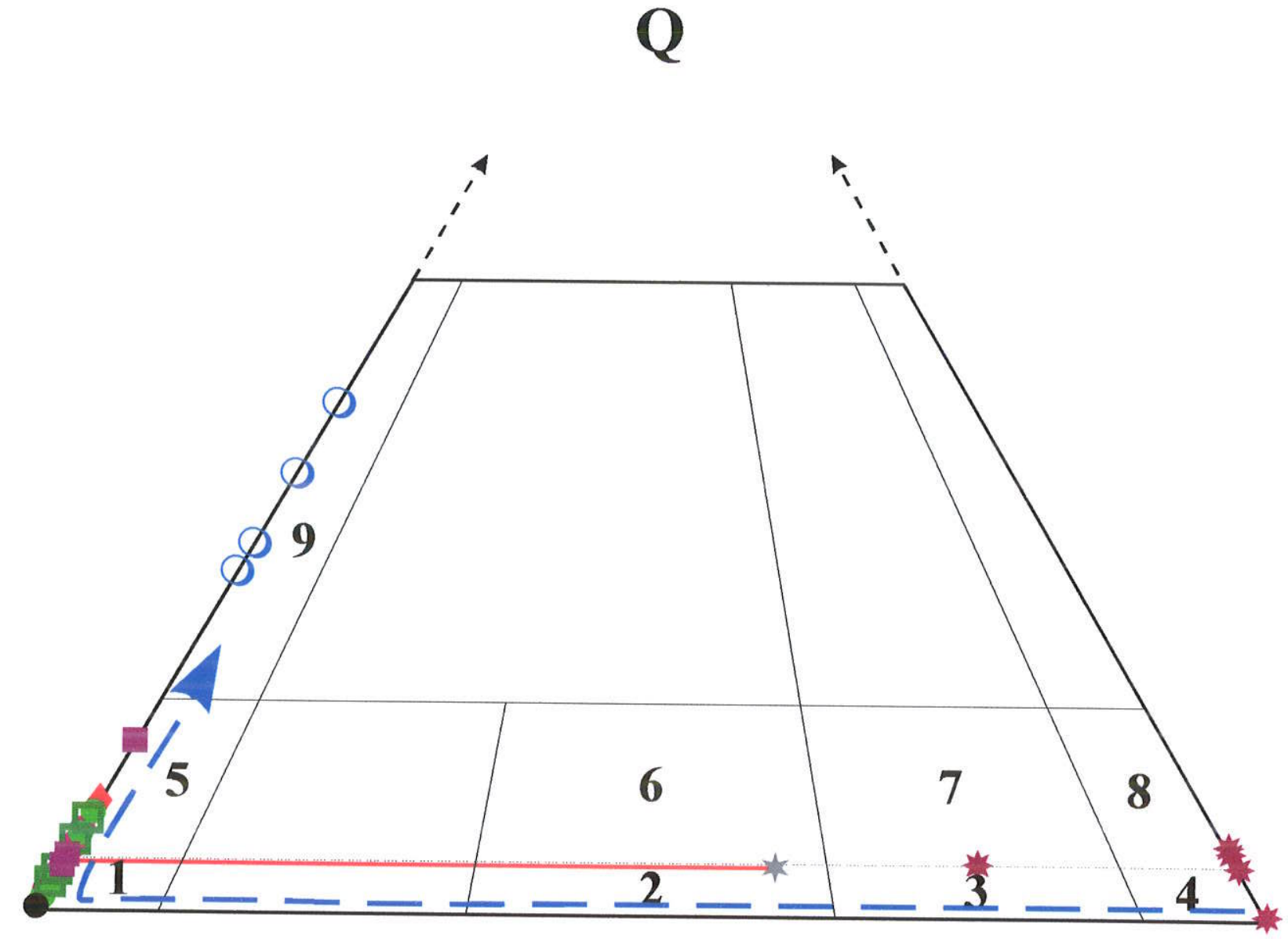

$\mathbf{A}$

Figura IV.2. Classificação modal das fácies petrográficas do Maciço Corupá, no diagrama Q-A-P (Streckeisen 1973).

Campos: 1- Álcali-feldspato sienito; 2- Monzonito; 3- Monzodioríto; 4- Diorito; 5- Álcali-feldspato quartzo-sienito; 6- Quartzo monzonito; 7- Quartzo monzodiorito 8- Quartzo diorito; 9- Álcali-feldspato granito.

Legenda: O Granito médio; • Sienito róseo grosso; - Sienito róseo médio; - Sienito verde grosso; $\square$ Sienito verde médio; - Melasienito; Diorito médio-fino; * Enclave monzonítico

A linha cheia em vermelho une o enclave monzonítico e a rocha hospedeira (sienito róseo médio). A linha pontilhada em azul representa a tendência evolutiva das rochas alcalinas supersaturadas, segundo Lameyre e Bowden (1982). 


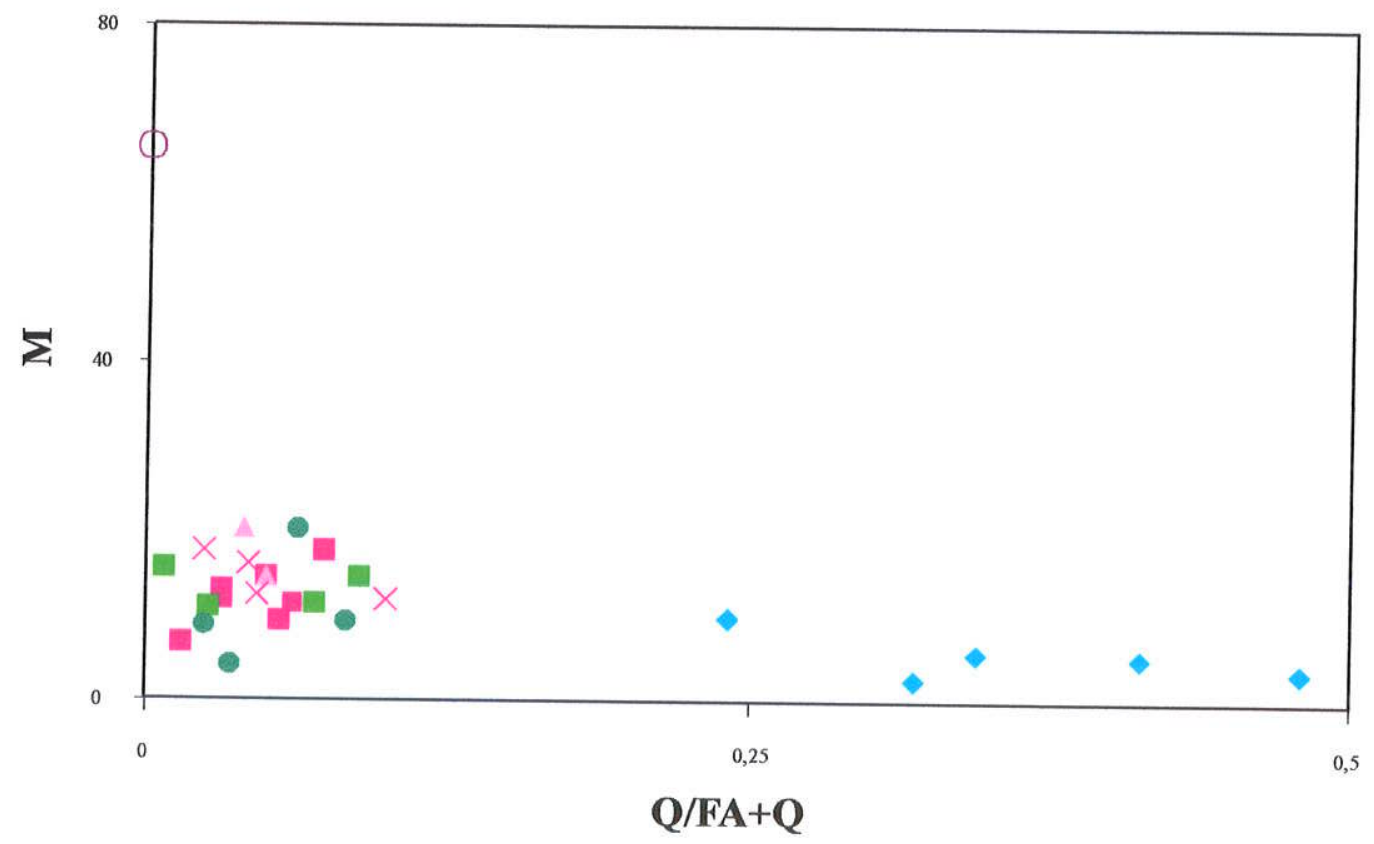

Figura IV.3. Diagrama de variação envolvendo o parâmetro $(Q / F A+Q)$ e o volume total de minerais máficos (\%) para as rochas das fácies granitica e sienitica.

Legenda: - Granito médio; - Sienito róseo grosso; ^ Sienito róseo médio; $\quad \times$ Sienito róseo fino; - Sienito verde grosso; - Sienito verde médio; O Melasienito.

Q: quartzo; FA: feldspato alcalino; M: volume total de minerais máficos (piroxênio+anfibólio+biotita+minerais opacos+acessórios), em \%. 
Tabela IV.2- Dados modais, em \% de volume mineral, de amostras representativas das fácies petrográficas do Maciço Corupá.

\begin{tabular}{|c|c|c|c|c|c|c|c|c|c|c|c|c|c|c|}
\hline $\begin{array}{c}\text { Fácies } \\
\text { Perográfica }\end{array}$ & Amostra & $\mathbf{F} \cdot \mathbf{A} .^{(i)}$ & $\mathbf{P I}^{(2)}$ & $\mathrm{Qtz}^{(2)}$ & $C p x^{(2)}$ & $\mathrm{Cam}^{(2)}$ & $B t^{(2)}$ & $\mathrm{OI}^{(2)}$ & $O p^{(3)}$ & $\operatorname{Ap}^{(2)}$ & $\operatorname{Zrn}^{(2)}$ & $\mathrm{Chv}^{(2)}$ & $\operatorname{Sec}^{(4)}$ & $M^{(5)}(\%)$ \\
\hline Microgranito & $\operatorname{Cos} 13$ & 60,5 & - & 28,9 & 6,3 & 1,0 & - & $\dot{-}$ & 4,1 & 0,1 & - & - & - & 11,5 \\
\hline $\begin{array}{l}\text { Granito } \\
\text { médio }\end{array}$ & $\begin{array}{l}\text { Co- } 54 \\
\mathrm{Co}-53 \\
\mathrm{Co}-2 A \\
S 9\end{array}$ & $\begin{array}{l}50,2 \\
55,7 \\
61,2 \\
65,8\end{array}$ & $\begin{array}{l}- \\
-\end{array}$ & $\begin{array}{l}46,2 \\
39,1 \\
32,3 \\
30,9\end{array}$ & $\begin{array}{l}- \\
- \\
- \\
-\end{array}$ & $\begin{array}{l}3,5 \\
4,4 \\
4,5 \\
1,8\end{array}$ & $\begin{array}{l}- \\
- \\
-\end{array}$ & . & $\begin{array}{l}0,1 \\
0,8 \\
0,9 \\
0,7\end{array}$ & $\ddot{0}, 1$ & $\begin{array}{l}- \\
- \\
-\end{array}$ & $\begin{array}{l}- \\
- \\
-\end{array}$ & $\begin{array}{c}<0,1 \\
<0,1 \\
1,1 \\
.\end{array}$ & $\begin{array}{l}3,6 \\
5,2 \\
5,5 \\
2,5 \\
\end{array}$ \\
\hline $\begin{array}{l}\text { Sienito róseo } \\
\text { grosso }\end{array}$ & $\begin{array}{l}\text { Co- } 4 A \\
\text { Co- } 9 A \\
C o-32 B \\
\text { Co- 32F1 } \\
\text { Co-32A } \\
\text { Co-51 } \\
\end{array}$ & $\begin{array}{l}80,3 \\
79,2 \\
85,5 \\
84,3 \\
91,9 \\
85,6 \\
\end{array}$ & $\begin{array}{l}- \\
- \\
- \\
- \\
-\end{array}$ & $\begin{array}{l}6,4 \\
4,1 \\
5,0 \\
2,7 \\
1,3 \\
2,7 \\
\end{array}$ & $\begin{array}{l}2,4 \\
2,5 \\
1,8 \\
3,7 \\
2,3 \\
5,0 \\
\end{array}$ & $\begin{array}{l}3,7 \\
3,6 \\
6,3 \\
5,6 \\
2,0 \\
4,1 \\
\end{array}$ & $\begin{array}{c}0,3 \\
- \\
<0,1 \\
- \\
1,2 \\
- \\
\end{array}$ & $\begin{array}{l}- \\
- \\
- \\
- \\
\end{array}$ & $\begin{array}{l}4,3 \\
8,2 \\
1,2 \\
3,3 \\
0,8 \\
2,6 \\
\end{array}$ & $\begin{array}{c}0,5 \\
- \\
0,2 \\
0,5 \\
0,2 \\
<0,1 \\
\end{array}$ & $\begin{array}{c}0,1 \\
- \\
- \\
- \\
<0,1 \\
<0,1 \\
\end{array}$ & $\begin{array}{l}- \\
- \\
- \\
- \\
0,1 \\
-\end{array}$ & $\begin{array}{l}2,7 \\
2,4 \\
<0,1 \\
<0,1 \\
<0,1 \\
<0,1 \\
\end{array}$ & $\begin{array}{c}17,7 \\
14,3 \\
9,5 \\
13,1 \\
6,6 \\
11,7 \\
\end{array}$ \\
\hline $\begin{array}{c}\text { Sienito róseo } \\
\text { médio }\end{array}$ & $\begin{array}{l}C o-4 B \\
C o-38 \\
C o-16 A \\
C o-6 D \\
\end{array}$ & $\begin{array}{l}82,2 \\
73,3 \\
81,0 \\
76,5 \\
\end{array}$ & $\begin{array}{l}- \\
- \\
-\end{array}$ & $\begin{array}{c}5,4 \\
16,7 \\
4,2 \\
3,2 \\
\end{array}$ & $\begin{array}{l}3,7 \\
1,7 \\
3,9 \\
4,1 \\
\end{array}$ & $\begin{array}{r}3,9 \\
7,2 \\
8,7 \\
10,6 \\
\end{array}$ & $\begin{array}{c}0,4 \\
- \\
- \\
- \\
\end{array}$ & $\begin{array}{l}- \\
- \\
- \\
\end{array}$ & $\begin{array}{l}3,1 \\
0,7 \\
2,0 \\
5,1 \\
\end{array}$ & $\begin{array}{l}0,2 \\
0,1 \\
0,2 \\
0,5 \\
\end{array}$ & $\begin{array}{c}<0,1 \\
<0,1 \\
- \\
-\end{array}$ & $\begin{array}{c}0,3 \\
0,2 \\
<0,1 \\
- \\
\end{array}$ & $\begin{array}{l}1,7 \\
0,1 \\
<0,1 \\
<0,1 \\
\end{array}$ & $\begin{array}{c}11,6 \\
9,9 \\
14,8 \\
20,3 \\
\end{array}$ \\
\hline $\begin{array}{l}\text { Sienito róseo } \\
\text { fino }\end{array}$ & $\begin{array}{l}\mathrm{Co}-32 B \\
\mathrm{Co}-44 B \\
\mathrm{Co}-40 B \\
\mathrm{Co}-32 \mathrm{~F} 2 \\
\end{array}$ & $\begin{array}{l}79,1 \\
83,4 \\
81,4 \\
80,2 \\
\end{array}$ & $\begin{array}{l}- \\
- \\
-\end{array}$ & $\begin{array}{l}8,7 \\
4,0 \\
3,6 \\
1,9 \\
\end{array}$ & $\begin{array}{c}2,0 \\
<0,1 \\
0,9 \\
2,0 \\
\end{array}$ & $\begin{array}{r}6,0 \\
8,9 \\
13,9 \\
11,0 \\
\end{array}$ & . & $\begin{array}{l}- \\
- \\
- \\
\end{array}$ & $\begin{array}{l}3,3 \\
1,1 \\
1,0 \\
3,9 \\
\end{array}$ & $\begin{array}{l}0,8 \\
0,1 \\
0,1 \\
0,5\end{array}$ & $\begin{array}{c}0,1 \\
- \\
0,1 \\
0,2 \\
\end{array}$ & $\begin{array}{l}- \\
2,4 \\
- \\
\end{array}$ & $\begin{array}{c}- \\
<0,1 \\
<0,1 \\
0,3 \\
\end{array}$ & $\begin{array}{l}12,2 \\
12,6 \\
16,0 \\
17,6 \\
\end{array}$ \\
\hline $\begin{array}{l}\text { Sienito verde } \\
\text { grosso }\end{array}$ & $\begin{array}{l}C O-1 \\
C O-4 C \\
C O-50 A \\
C O-32 C\end{array}$ & $\begin{array}{l}78,5 \\
82,0 \\
86,5 \\
84,6\end{array}$ & $\begin{array}{l}- \\
- \\
-\end{array}$ & $\begin{array}{l}7,7 \\
6,1 \\
2,3 \\
0,7\end{array}$ & $\begin{array}{l}7,5 \\
4,3 \\
4,7 \\
7,2\end{array}$ & $\begin{array}{l}1,8 \\
1,5 \\
3,9 \\
1,0\end{array}$ & $\begin{array}{c}0,1 \\
2,5 \\
-\end{array}$ & $\begin{array}{c}1,0 \\
0,3 \\
<0,1 \\
0,5\end{array}$ & $\begin{array}{l}1,8 \\
2,3 \\
2,3 \\
1,8\end{array}$ & $\begin{array}{l}2,3 \\
0,3 \\
0,2 \\
0,6\end{array}$ & $\begin{array}{c}0,1 \\
0,1 \\
<0,1 \\
<0,1\end{array}$ & $\begin{array}{l}- \\
- \\
-\end{array}$ & $\begin{array}{l}1,2 \\
3,1 \\
<0,1 \\
<0,1\end{array}$ & $\begin{array}{l}14,6 \\
11,3 \\
11,1 \\
15,6\end{array}$ \\
\hline
\end{tabular}


Tabela IV.2- Contimuação

\begin{tabular}{|c|c|c|c|c|c|c|c|c|c|c|c|c|c|c|}
\hline $\begin{array}{c}\text { Fácies } \\
\text { Perográfica }\end{array}$ & Amostra & F. A. ${ }^{(i)}$ & $\mathrm{Pl}^{(2)}$ & $Q t z^{(2)}$ & $\mathrm{Cpx}^{(2)}$ & $\mathrm{Cam}^{(2)}$ & $\mathbf{B} \varepsilon^{(2)}$ & $\mathrm{Ol}^{(2)}$ & $O p^{(3)}$ & $A p^{(2)}$ & $\mathrm{Zrn}^{(2)}$ & $\mathrm{Chw}^{(2)}$ & $\operatorname{Sec}^{(4)}$ & $M^{(5)}(\%)$ \\
\hline $\begin{array}{l}\text { Sienito verde } \\
\text { médio }\end{array}$ & $\begin{array}{l}C O-3 B \\
C O-42 A \\
C O-5\end{array}$ & $\begin{array}{l}82,1 \\
91,2 \\
87,3\end{array}$ & - & $\begin{array}{l}7,5 \\
3,3 \\
2,1\end{array}$ & $\begin{array}{l}3,9 \\
0,2 \\
3,5\end{array}$ & $\begin{array}{l}2,8 \\
3,0 \\
2,3\end{array}$ & $\begin{array}{c}1,4 \\
<0,1 \\
1,2\end{array}$ & $\begin{array}{l}- \\
-\end{array}$ & $\begin{array}{l}0,5 \\
0,8 \\
1,1\end{array}$ & - & $\begin{array}{c}0,6 \\
- \\
0,4\end{array}$ & $\begin{array}{c}- \\
0.1\end{array}$ & $\begin{array}{c}1,2 \\
<0,1 \\
2,2\end{array}$ & $\begin{array}{l}9,2 \\
4,0 \\
8,6\end{array}$ \\
\hline Melasienito & $C O-32 D$ & 34,7 & - & & 19,1 & - & 1,8 & 28,5 & 9,8 & 5,6 & 0,5 & - & - & 65,3 \\
\hline $\begin{array}{c}\text { Dioritose } \\
\text { rochas } \\
\text { híbridas }\end{array}$ & $\begin{array}{l}C O-45 D \\
C o-34 B \\
C o-32 H \\
C o-50 B \\
C o-22\end{array}$ & $\begin{array}{c}- \\
15,5 \\
- \\
-\end{array}$ & $\begin{array}{l}62,2 \\
61,3 \\
53,8 \\
60,8 \\
61,6\end{array}$ & $\begin{array}{c}8,2 \\
4,6 \\
3,4 \\
2,9 \\
<0,1\end{array}$ & $\begin{array}{c}13,0 \\
15,1 \\
8,0 \\
9,4 \\
17,5\end{array}$ & $\begin{array}{c}0,2 \\
8,3 \\
5,8 \\
19,5 \\
0,1\end{array}$ & $\begin{array}{c}8,3 \\
3,3 \\
11,7 \\
4,2 \\
14,8\end{array}$ & $\begin{array}{l}. \\
. \\
.\end{array}$ & $\begin{array}{l}5,7 \\
3,3 \\
1,4 \\
3,1 \\
4,7\end{array}$ & $\begin{array}{c}1,0 \\
4,0 \\
0,3 \\
<0,1 \\
1,6\end{array}$ & $\begin{array}{c}0,1 \\
<0,1 \\
- \\
- \\
<0,1\end{array}$ & $\begin{array}{l}- \\
- \\
-\end{array}$ & $\begin{array}{c}1,4 \\
<0,1 \\
<0,1 \\
<0,1 \\
0,2\end{array}$ & $\begin{array}{l}28,3 \\
30,0 \\
27,2 \\
36,2 \\
38,7\end{array}$ \\
\hline $\begin{array}{c}\text { Enclave } \\
\text { monzonítico }\end{array}$ & $\mathrm{Co}-6 \mathrm{C}$ & 27,4 & 42,0 & 3,2 & 14,2 & 1,8 & 7,6 & - & 2,0 & 0,7 & $<0,1$ & . & - & 26,3 \\
\hline
\end{tabular}

(1) Feldspato alcalino / (2) Abreviaturas segundo Kretz (1983) / (3) Minerais opacos (Ilmenita, Hematita e Magnetita) / (4) Minerais secundários originados por alteração hidrotermal e/ou deutérica / (5) $\mathrm{M}=$ volume $\%$ de minerais máficos. 


\section{IV.4. A seqüência de cristalização das rochas do Maciço Corupá}

As relações texturais entre os minerais constituintes das rochas graníticas, sieníticas e dioríticas do Maciço Corupá observadas em seções delgadas permitem sugerir a seqüência de cristalização das fases minerais presentes. Uma interpretação simples é oferecida a seguir e representada esquematicamente nas Figuras $I V .4, I V .5$ e IV.6.

No caso das rochas graníticas do maciço, a cristalização no estágio magmático se inicia com feldspato alcalino e/ou apatita e zircão, seguidos de perto por ilmenita e chevkinita. Anfibólio cálcico-sódico é algo posterior, sendo seguido de perto pelo quartzo. Ao final do estágio magmático, precipitam anfibólio sódico e intercrescimentos microgranofíricos entre feldspato alcalino e quartzo. Fenômenos de exsolução de hematita na ilmenita e no feldspato alcalino, bem como o desenvolvimento de albita intersticial e anfibólio sódico são típicos dos estágios tardi- a pós-magmáticos. No estágio hidrotermal, aparecem quartzo, hematita e outros minerais secundários, além de allanita rica em Fe (Vlach, 1999), epídoto e zircão, como preenchimento de fraturas e miarolas, indicando que nestes estágios finais houve um incremento na atividade de elementos como Ca e Al.

Nas rochas sieníticas, o estágio magmático inicia-se pela cristalização de olivina, seguida de perto por acessórios como apatita, ilmenita e magnetita e, após, por clinopiroxênio salítico incolor a levemente rosado, zircão, chevkinita, e anfibólio cálcico. Esta seqüência parece ser bem marcada nos melasienitos e sienitos verdes de granulação mais grossa. Segue o clinopiroxênio hedenbergítico e, mais tardiamente, o anfibólio cálcico-sódico, que tornam-se progressivamente mais importantes. A substituição de piroxênio salítico para hedenbergítico parece ter sido mais brusca, enquanto o anfibólio torna-se de modo normal a oscilatório, mas continuamente, mais sódico. As relações texturais entre piroxênio e anfibólio indicam também que este substitui, pelo menos parcialmente, o primeiro. Magnetita primária aparece apenas nos melasienitos, enquanto a olivina aparece apenas nos melasienitos e nos sienitos verdes grossos, não sendo mais observadas nas demais rochas do maciço. Este fato sugere algum tipo de reação peritética responsável pelo desaparecimento destes minerais ou, alternativamente, extração de magmas residuais nos quais estes minerais não seriam mais estáveis. 
Entre os minerais félsicos, o feldspato alcalino é precoce, acompanhando de perto o clinopiroxênio de primeira geração, o quartzo aparecendo somente nos estágios magmáticos mais tardios. Nos melasienitos, biotita também é um mineral magmático tardio. Fenômenos de exsolução, tardi- a pós-magmáticos foram provavelmente similares aos descritos para as rochas graníticas.

Minerais mais tipicamente hidrotermais incluem quartzo, biotita, filossilicatos não identificados, hematita, magnetita, zircão e anfibólio actinolítico, tal como aparecem intersticialmente de forma mais típica nos sienitos de granulação grossa. Novamente nota-se que, nestes estágios, aparecem paragêneses mais ricas em Ca.

Nas rochas dioríticas a cristalização tem início no estágio magmático com plagioclásio e apatita, seguidos por biotita e ilmenita. Anfibólio e clinopiroxênio iniciam a cristalização um pouco depois, com o último cristalizando por um período um pouco maior. A magnetita precipita logo após estes minerais, seguindo até o final do estágio magmático. Ao final deste estágio ocorre o aparecimento do feldspato alcalino, seguido pelo quartzo, que continua sua cristalização até o início do próximo estágio. $O$ zircão constitui uma fase mais tardia nestas rochas. Lamelas de exsolução de hematita, hospedados em cristais de ilmenita, aparecem na interface dos estágios magmático e tardi-pós magmático. 


\begin{tabular}{|c|c|c|c|}
\hline & \multicolumn{3}{|c|}{ Estágios } \\
\hline Minerais & Magmático & Tardi/pós-magmático & Hidrotermal \\
\hline \multirow{3}{*}{$\begin{array}{l}\text { Feldspato } \\
\text { Alcalino }\end{array}$} & & Pertitas & \\
\hline & \multirow[t]{2}{*}{ Feldspato alcalino } & & \\
\hline & & Albita & \\
\hline \multicolumn{4}{|l|}{ Qtz } \\
\hline \multicolumn{4}{|l|}{$C p x^{(1)}$} \\
\hline Cam & CanNa & Na & \\
\hline \multirow{2}{*}{$O_{p}$} & \multirow{2}{*}{ Ilmenita } & & Hematua \\
\hline & & & \\
\hline \multicolumn{4}{|l|}{ Ap } \\
\hline \multicolumn{4}{|l|}{ Zrm } \\
\hline \multicolumn{4}{|l|}{ Epd } \\
\hline \multicolumn{4}{|l|}{ Chy } \\
\hline $\operatorname{Sec}^{(2)}$ & & & \\
\hline
\end{tabular}

Figura IV.4. Provável ordem de cristalização mineral das rochas graniticas do Maciço Corupá.

(1) Relativo aos microgranitos, ou seja, aos diques graníticos tardios relacionados às bacias vulcano-sedimentares / (2) Minerais secundários originados por alteração hidrotermal e/ou deutérica / Abrevições dos minerais segundo Kret\% (1983). 


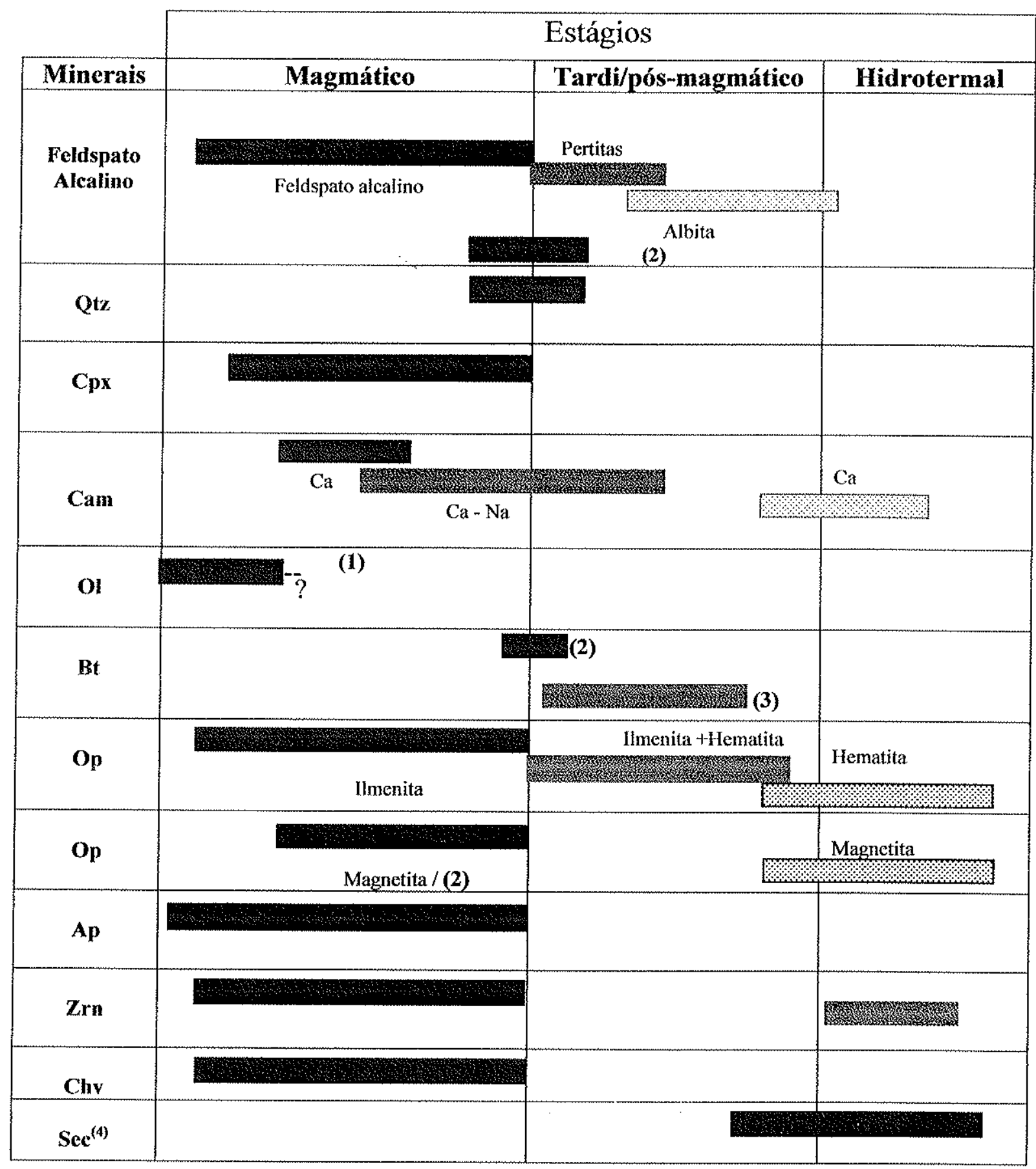

Figura IV.5. Provóvel ordem de cristalização mineral das rochas sieníticas do Maciço Cornupá.

(1) Relativo somente às fácies sieniticas verde e melasieníticas / (2) Relativo à fácies melasienítica (3) Relativo às fácies sieníticas verde / (4) Minerais secundários originados por alteração hidrotermal e/ou deutérica / Abreviaç̃es dos minerais segundo Kretz (1983). 


\begin{tabular}{|c|c|c|c|}
\hline & \multicolumn{3}{|c|}{ Estágios } \\
\hline Minerais & Magmático & Tardi/pós-magmático & Hidrotermal \\
\hline \multicolumn{4}{|l|}{ Plagioclásio } \\
\hline $\begin{array}{c}\text { Feldspato } \\
\text { Alcalino }\end{array}$ & $\begin{array}{l}\text { Feldspato } \\
\text { alcalino }\end{array}$ & $\begin{array}{l}\text { Lamelas } \\
\text { albiticas }\end{array}$ & \\
\hline \multicolumn{4}{|l|}{ Qtz } \\
\hline \multicolumn{4}{|l|}{ Cpx } \\
\hline \multicolumn{4}{|l|}{ Cam } \\
\hline \multicolumn{4}{|l|}{ Bt } \\
\hline Op & Ilmzenita & $\begin{array}{l}\text { Ilmenita + } \\
\text { Hematita }\end{array}$ & \\
\hline \multicolumn{4}{|c|}{ Magnetita } \\
\hline \multicolumn{4}{|l|}{ Ap } \\
\hline \multicolumn{4}{|l|}{ Zrn } \\
\hline $\operatorname{Sec}^{(1)}$ & & & \\
\hline
\end{tabular}

Figura IV.6. Provável ordem de cristalização mineral das rochas de composição diorítica do Maciço Corupá.

(1)Minerais secundários originados por alteração hidroternal e/ou deutérica / Abreviaçð̃es dos minerais segundo Kretz (1983). 


\section{Capitulo V}

Texturas e quimismo mineral 


\section{V.1 Minerais Máficos}

Apresenta-se a seguir o estudo da textura e do quimismo dos minerais máficos e félsicos das principa is rochas do Maciço Corupá. Em casos específicos compara-se os dados químícos obtidos neste trabalho com os existentes para rochas monzodioríticas, quartzo-sieníticas e graníticas da associação alcalina dos Granitos da Graciosa, da mesma província, estudados por Gualda (2001).

\section{V.1.1 Olivina}

Olivina é um mineral abundante na fácies melasienítica (Amostra Co-32D). Nas rochas sieníticas félsicas, a olivina está presente apenas nas variedades verdes de granulação grossa (por exemplo, Amostra Co-32C), em quantidades acessórias.

\section{V.1.1.1 Texturas}

No melasienito, a olivina forma cristais subdiomórficos e idiomórficos relativamente límpidos (Figura V.4B). Ocorre, em geral, em agregados de diversos cristais com contatos mútuos retos, por vezes junto ao clinopiroxênio, constituindo as principais fases minerais de aspecto cumulático nestas rochas. Alguns cristais apresentam bordas substituídas por finos agregados de biotita de pleocroísmo cor castanha-avermelhada.

Nos sienitos verdes de granulação grossa a olivina aparece com mais frequência como cristais subidiomórficos isolados ou em agregados em que se associa com clinopiroxênio, anfibólio e ilmenita (Fïgura $V .4 A$,). Alguns grãos aparecem muito alterados, sendo substituídos por finos agregados de filossilicatos secundários, por vezes contendo algum anfibólio. Em outras vezes, a presença pretérita de olivina só é deduzida pela presença de pșeudomorfos iddingsíticos marronalaranjados. 


\section{V.1.1.2 Quimismo}

As composições da olivina evidenciam uma significativa variabilidade entre as fácies sienítica verde e melasienítica, as presentes na última, sendo claramente mais primitivas. A fácies sienítica verde de granulação grossa apresenta cristais de composição fayalítica ( $\mathrm{Fa}_{90.92}$ ), com mg\# em torno de 0,10 , enquanto que na fácies melasienítica as olivinas possuem composição ferrohortonolítica (Fa76-80) com mg\# entre 0,20 e 0,23 (Figura V.I).

Os teores de Mn pouco variam em cristais da mesma amostra, mas são em média significativamente superiores nos sienitos (mn\# igual ou superior a 0,037 ), quando comparados aos do melasienito (mn\# igual ou inferior a 0,036 ) (Fïgura V.2 e V.3), os teores de CaO são sempre baixos, inferiores a 0,30 (Tabela V.I). Os cristais analisados apresentam composições bastante homogêneas; as variações químicas núcleo-borda mais significativas incluem uma leve, porém irregular, variação do parâmetro mg\# e uma efetiva diminuição dos teores de $\mathrm{CaO}$ (Tabela V.I) no cristal representativo dos sienitos. Em geral, as variações composicionais da olivina nestas rochas podem ser explicadas por substituições simples envolvendo a troca de $(\mathrm{Mg}, \mathrm{Fe})$ por $\mathrm{Mn}$ e algum $\mathrm{Ca}$. Os dados obtidos sugerem também uma possível lacuna composicional de olivina nestas fácies petrográficas.

As composições determinadas para olivina presente nas fácies sieníticas verdes são, de modo geral, mais ricas em Mg quando comparadas com as determinadas por Gualda (2001) em fácies da associação alcalina I dos Granitos da Graciosa. 


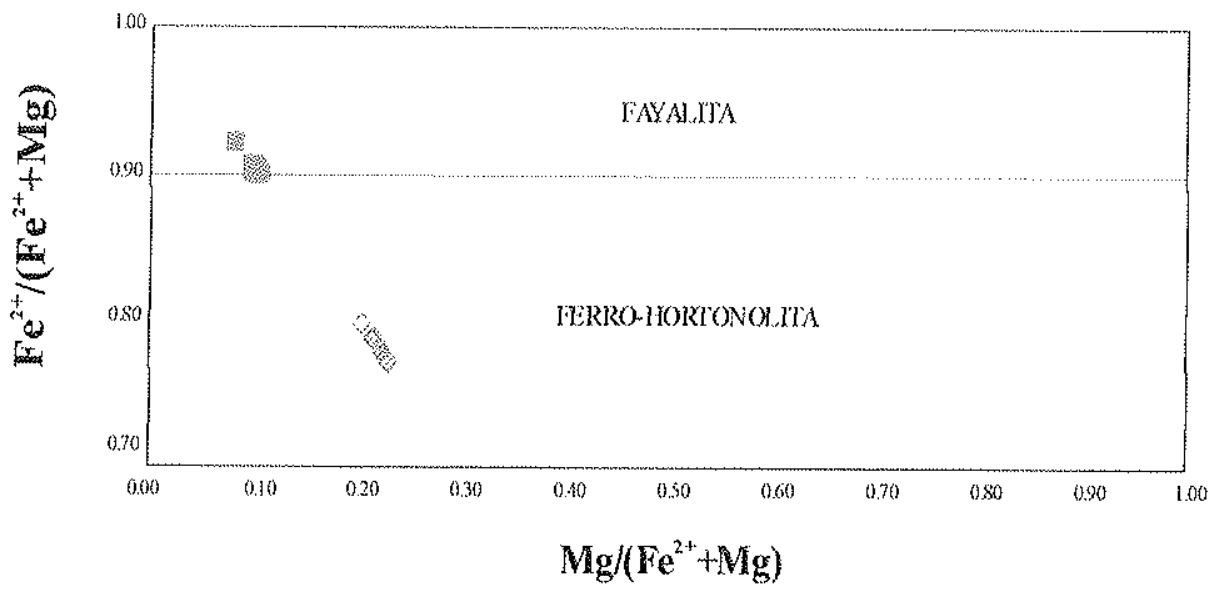

Figura Val. Diagrama cationnco $\left[\left(\mathrm{Mg} /\left(\mathrm{F} \mathrm{e}^{3+3}+\mathrm{Mg}\right) \times\left[\mathrm{e}^{2+} /\left(\mathrm{Fe} \mathrm{e}^{2+} \mathrm{Mg}\right)\right]\right.\right.$ para classificação da olivina das fácies sientica verde grossa e melasienitica.

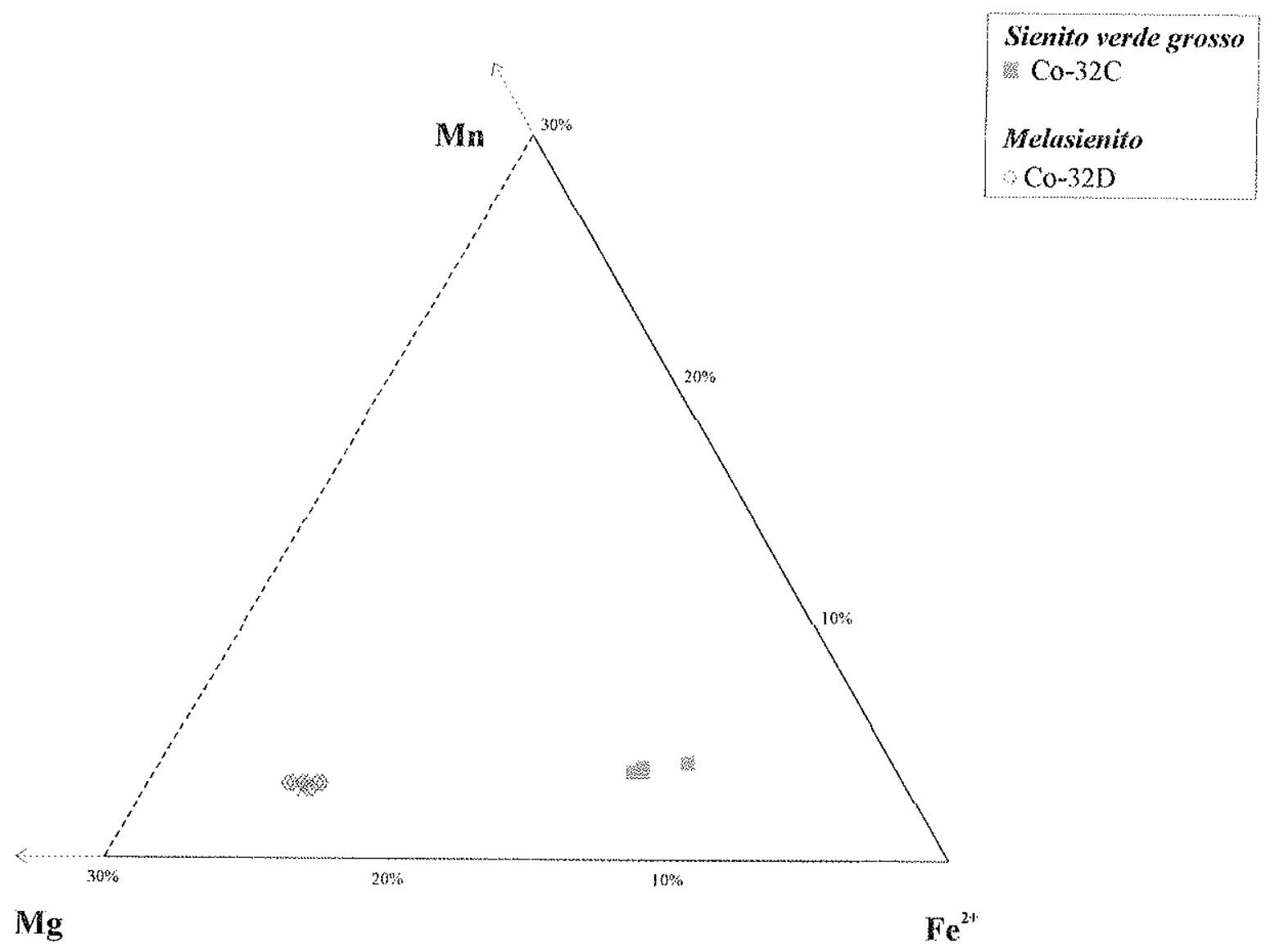

Figura V.2. Diagrama cationnico ( $\mathrm{Mn} \times \mathrm{Mg} \times \mathrm{Fe}^{2+}$ ) para olivina das fácies sienitica verde grossa e melasienitica. 


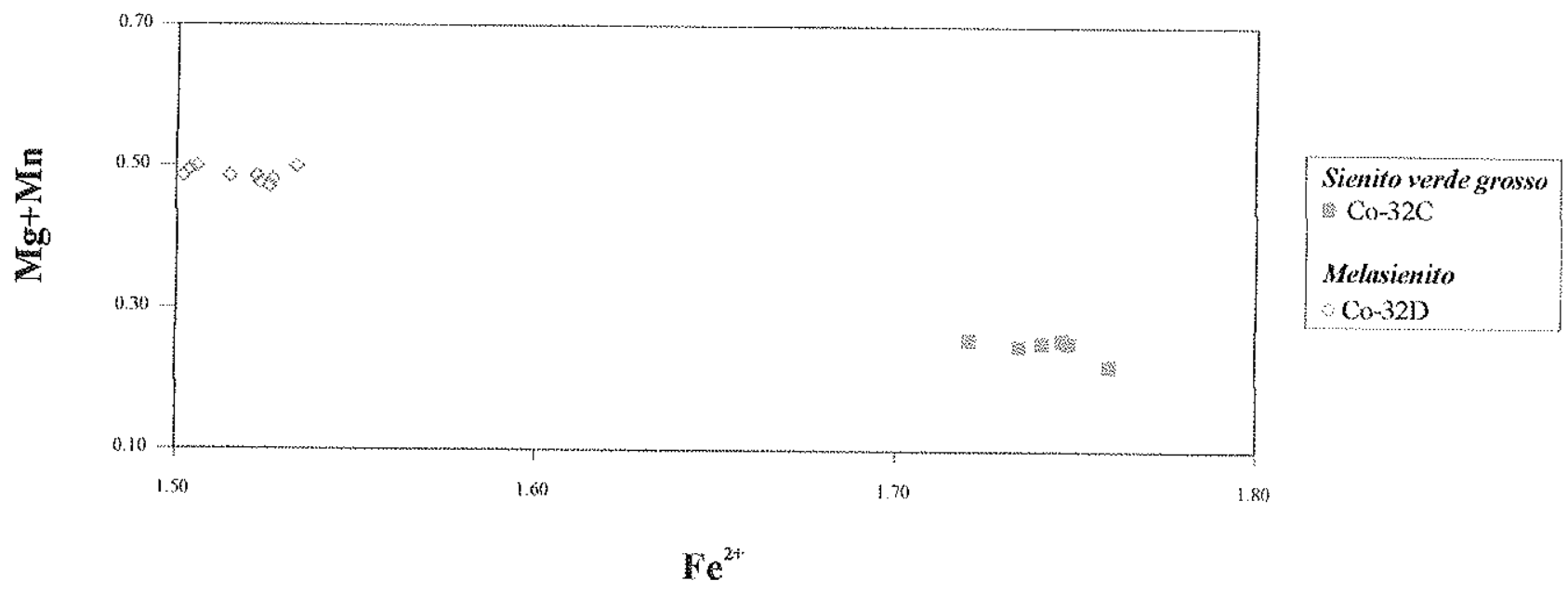

Figura V.3. Diagrama cationico $\left./ F^{2+4} \times(M g+M n)\right]$ ilustrando a tendência evolutiva da olivina do melasiento e do sienito verde grosso. 

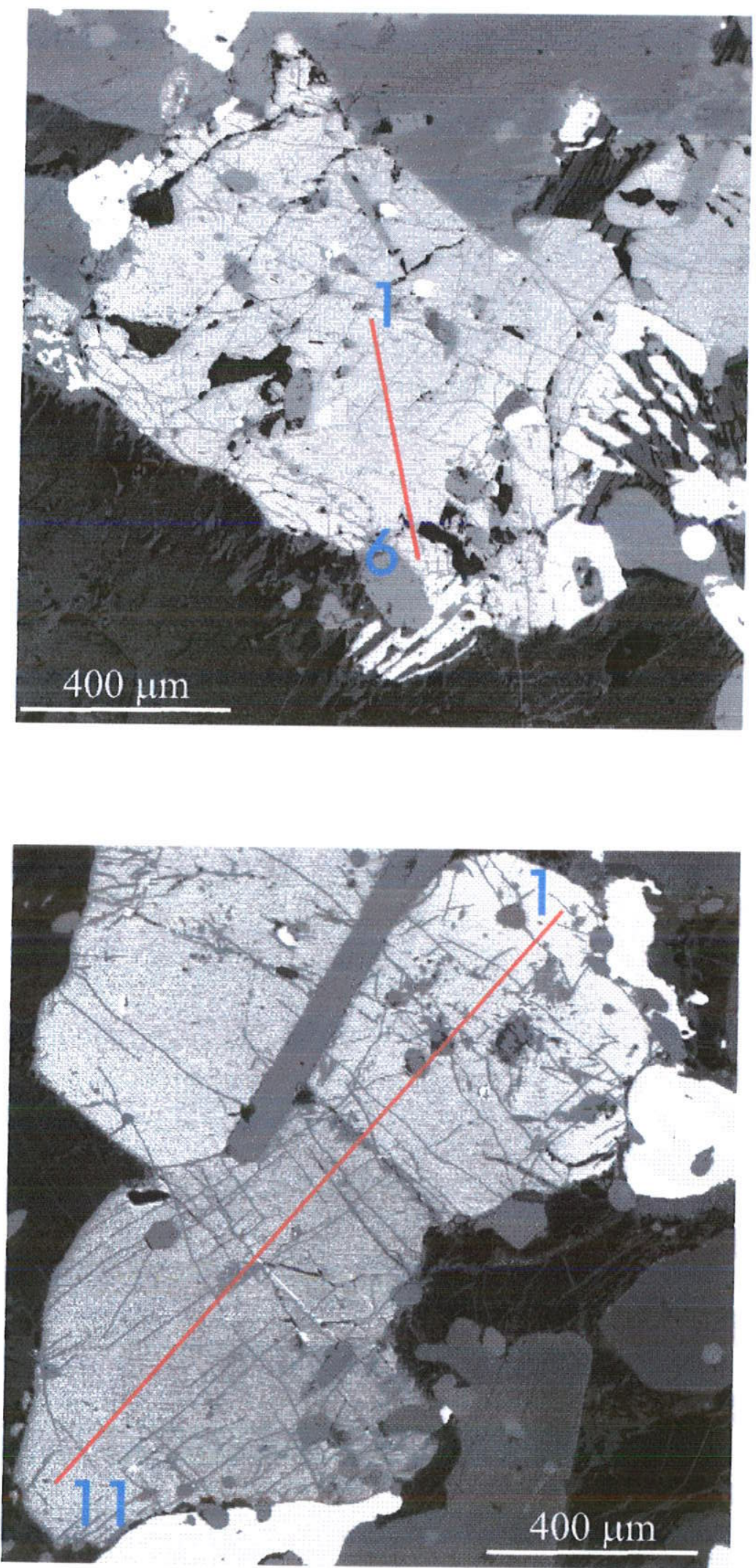

Figura V.4. Imagem de elétrons retro-espalhados, em modo composicional, de cristais de olivina, mostrando os perfis analiticos WDS efetuados e o número de análises em cada perfil. A: fácies sienítica verde de granulação grossa. Observar inclusões de apatita em cinza médio e ilmenita em claro. B: fácies melasienítica, também com inclusões de apatita; cristais mais claros correpondem a magnetita e ilmenita. 


\section{V.1.2 Clinopiroxênio}

Clinopiroxênio é um dos minerais máficos mais típicos das rochas álcali-feldspato sieníticas, melasieníticas e dioríticas do Maciço Corupá. Está ausente apenas nos álcali-feldspato granitos mais típicos.

\section{V.1.2.1 Texturas}

Nas rochas de composição diorítica e nos enclaves monzoníticos, os clinopiroxênios exibem um pleocroísmo incipiente em tons rosados e bordas de aspecto corroído. Podem ser observados minerais opacos e finos cristais de biotita inclusos (Figura V.IID)).

Os cristais de clinopiroxênio encontrados na fácies melasienítica são idiomórficos a subidiomórficos. A sua composição salítica é relativamente homogênea, o pleocroísmo é incipiente em tonalidades claras de rosa. Estes cristais de clinopiroxênio não exibem evidências de reação, estando em equilíbrio com as demais fases minerais, em particular com a olivina. Como inclusões podem apresentar minerais opacos e, principalmente, apatita.

Nas fácies sieniticas róseas e verdes o clinopiroxênio (Figura V.11A, V.11B e V.IIC) apresenta-se idiomórfico a subidiomórfico, apresentando zonamento composicional marcado por uma coloração rosa-clara no núcleo a verde nas bordas dos cristais. Alguns cristais presentes no sienitos róseo e verde grossos encontram-se com inclusões de finos cristais de ilmenita ao longo de sua clivagem.

\section{V.1.2.2 Quimismo}

O clinopiroxênio típico das rochas estudadas, exluindo-se aqui as bordas mais externas que aparecem com pleocroismo verde mais intenso presente em alguns sienitos, corresponde principalmente a soluções sólidas do quadrilateral Di-He-En-Fs, as análises obtidas distribuindo-se 
ao longo do eixo Di-He (Figura V.5) e indicando que o principal vetor de substituição é simples, do tipo (e.g. Deer et al., 1992):

$$
\mathrm{Fe}^{2 \mathrm{k}(\mathrm{MI}, \mathrm{M} 2)} \Leftrightarrow \mathrm{Mg}^{\mathrm{M} 1, \mathrm{M} 2}
$$

Nas rochas dioriticas e hibridas correspodem sempre a variedades de diopsidio. Nas amostras mais primitivas (Co-22, Co-50B), o clinopiroxênio apresenta valores de mgł entre 0,64 e 0,80 , enquanto que nas variedades híbridas estes valores variam de 0,78 a 0,58 e no enclave monzonítico entre 0,63 e 0,59 . No conjunto dos dados há uma certa tendência de diminuição da molécula Wo com o aumento do índice mgł. Nos cristais individuais, existe em geral diminuição dos valores mg\# em direção às bordas dos cristais (Tabela V.2).

O clinopiroxênio da fácies melasienítica é relativamente homogêneo; também corresponde a um diopsidio, porém os valores mg\# são significativamente inferiores aos das rochas dioriticas e híbridas, situando-se entre 0,51 e 0,57 . Estes valores, quando comparados aos obtidos para a olivina coexistente indicam que a estrutura do clinopiroxênio teve grande preferência na incorporação de $\mathrm{Mg}$ em detrimento ao $\mathrm{Fe}^{2+}$. Comparado ao clinopiroxênio presente nas rochas dioríticas, o dos melasienitos é adicionalmente algo mais pobre em $\mathrm{Al}_{2} \mathrm{O}_{3}, \mathrm{Na}_{2} \mathrm{O}$ e mais rico em MnO (Tabela V.2).

Nas fácies sieniticas, por sua vez, as composições do clinopiroxênio principal, levemente pleocróico, variam no intervalo da hedenbergita, com mg\# inferior a 0,48 , chegando a 0,15 . Apenas um ponto analítico, em núcleo de cristal da amostra Co-38, corresponde a um diopsídio com mg\# igual a 0,51 . Em geral, estas variações composicionais relacionam-se com as variações no padrão de pleocroismo dos cristais estudados, o aumento na molécula He sendo paralelizado por colorações tendendo levemente ao verde. Em geral observa-se um incremento nos teores de $\mathrm{MnO}$ em direção aos termos mais ricos na molécula de He (Tabela V.2; Figura V.5).

Nas bordas mais externas do clinopiroxênio presente nas fácies sieniticas, particularmente as mais diferenciadas, as composições hedenbergíticas passam para Na-hedembergíticas e finalmente para aegirina-augíticas, com teores de $\mathrm{Na}_{2} \mathrm{O}$ máximos de 4,6\% em peso (Fïgura V.6, Tabela V.2), 
indicando substituições acopladas entre os termos Di-He e a molécula de Ac, que podem ser descritas pela equação:

$$
\mathrm{Ca}^{\mathrm{M} 2}+\left(\mathrm{Fe}^{2+}, \mathrm{Mg}, \mathrm{Mn}, \mathrm{Al}^{3+}\right) \Leftrightarrow \mathrm{Na}^{\mathrm{M} 2}+\mathrm{Fe}^{3+(\mathrm{M} 1)}
$$

No diagrama da Figura $V .10$, a excelente correlação linear negativa obtida entre estes parâmetros é uma forte indicação para a ocorrência do referido mecanismo de substiuição nas rochas sieníticas.

A tendência evolutiva dos clinopiroxênios das rochas sieníticas do Maciço Corupá pode ser bem visualizada nos diagramas apresentados nas Figuras $V .7$ e V.8, em que se mostra que em uma primeira etapa estes evoluem para composições próximas a de uma hedenbergita quase pura para, em seguida, passarem para composições mais sódicas, aegirina-augíticas. A Figura V.9, em particular, mostra um detalhamento da tendência evolutiva dos clinopiroxênios analisados nos sienitos róseo e verde de granulação grossa (amostras Co-3D e Co-1, respectivamente).

Esta primeira etapa mimetiza a tendência observada em rochas da associação alcalina I e dos quartzo sienitos dos Granitos da Graciosa (Gualda, 2001), mas nestas últimas, composições mais sódicas (aegirina-augíticas) não foram encontradas. 


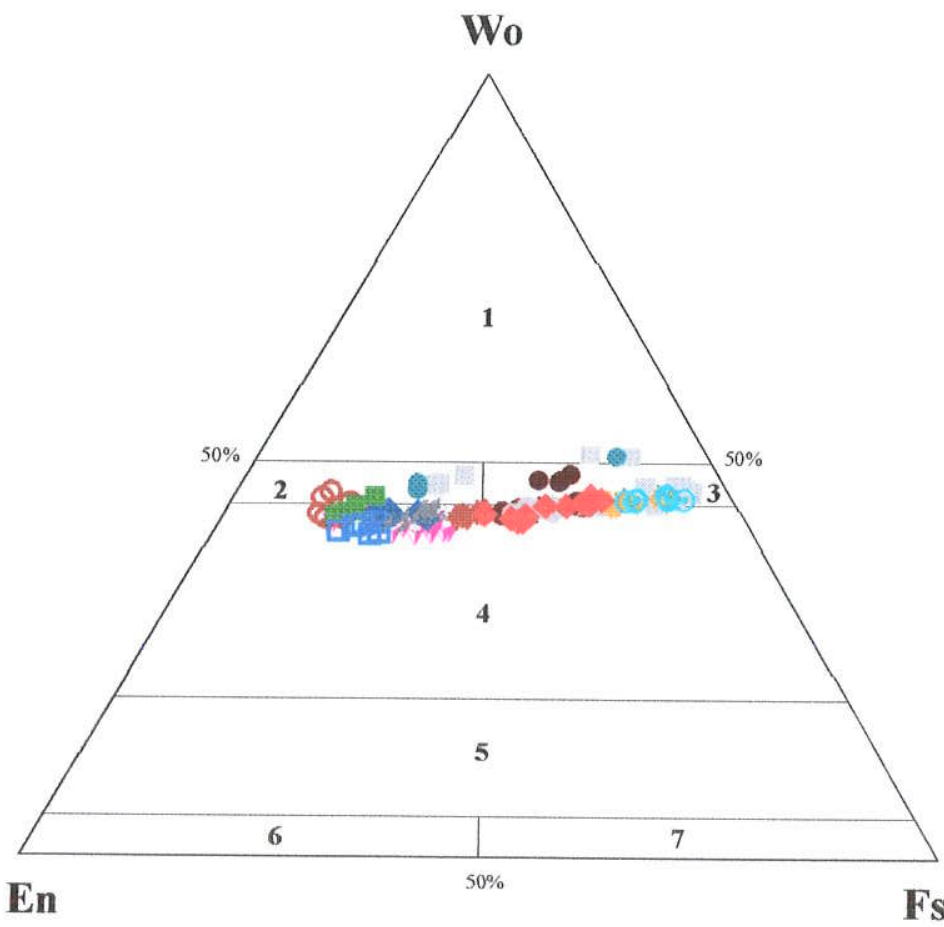

Figura V.5. Diagrama de classificação de clinopiroxênio (Morimoto, 1990) das fácies sieníticas, melasienítica, dioríticas/híbridas e dos enclaves monzoníticos.

Campos:1- Wollastonita; 2- Diopsídio; 3-Hedenbergita; 4- Augita; 5 Pigeonita; 6- Clinoenstatita; 7- Clinoferrosilita.

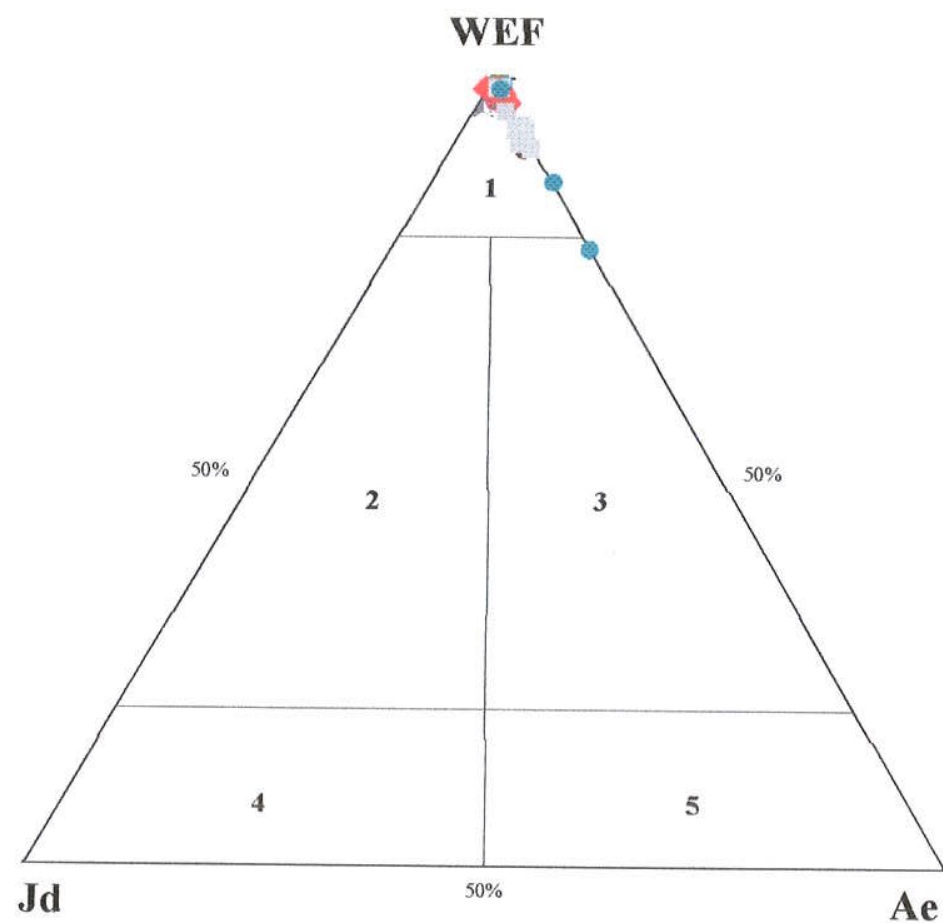

Figura V.6. Diagrama classificação de clinopiroxênio (Morimoto 1990) das fácies sieníticas, melasienítica, dioriticas/híbridas e dos enclaves monzoniticos.

Campos:1- Quadrilatero; 2- Omphacita; 3- Aegirina-Augita; 4-
Sienito róseo grosso

당 $\mathrm{Co} \mathrm{D}$

- Co-51

Sienito róseo médio

$$
\text { Co- } 4 \mathrm{~B}
$$

- Co-38

Sienito róseo fino

* Co-40B

Sienito verde grosso

Co-1

Co-50A

Sienito verde médio

(-) $\mathrm{Co}-5$

Melasienito

- Co-32D

Diorito / Rochas Híbridas

- Co-22

욜 $\mathrm{Co}-32 \mathrm{H}$

(1 Co-34B

$\square \quad \mathrm{Co}-4 \mathrm{D}$

( $\mathrm{Co}-50 \mathrm{~B}$

Enclave monzonítico

A. $\mathrm{Co}-6 \mathrm{C}$ 


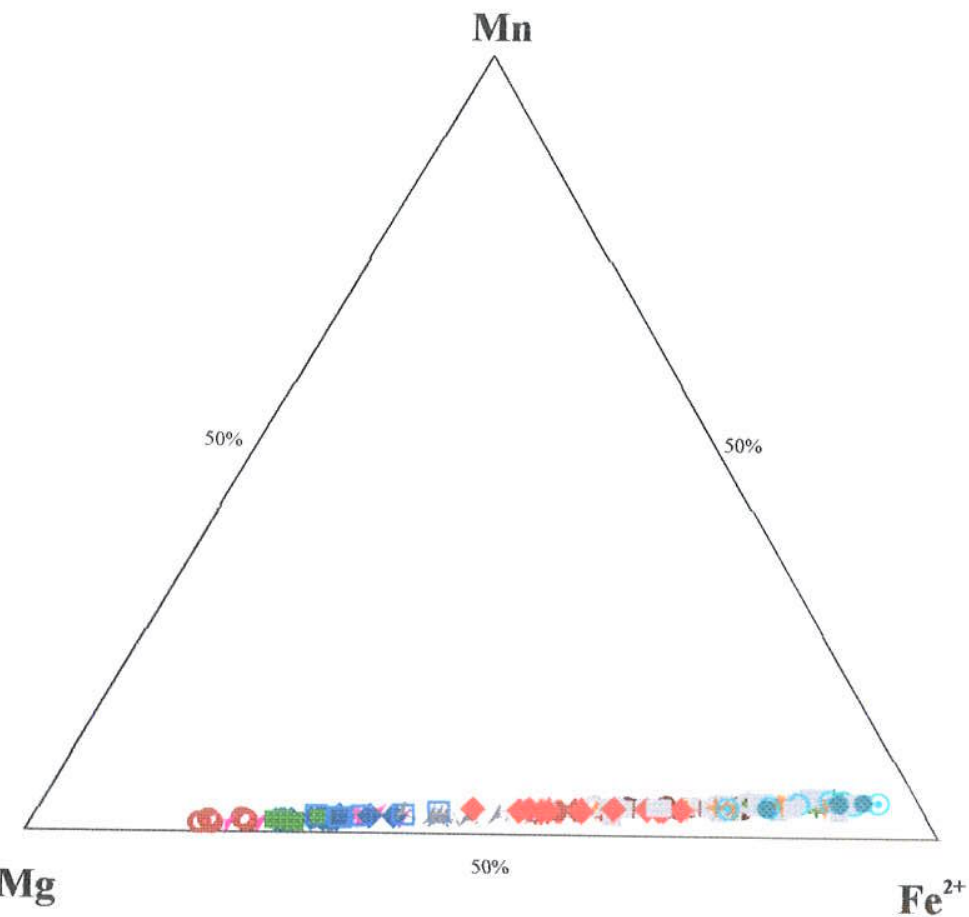

Figura V.7. Diagrama catiônico $\left(\mathrm{Mn} \times \mathrm{Mg} \times \mathrm{Fe}^{2+}\right)$ para clinopiroxênio das fácies sieníticas, melasienítica, dioríticas e dos enclaves monzoníticos.

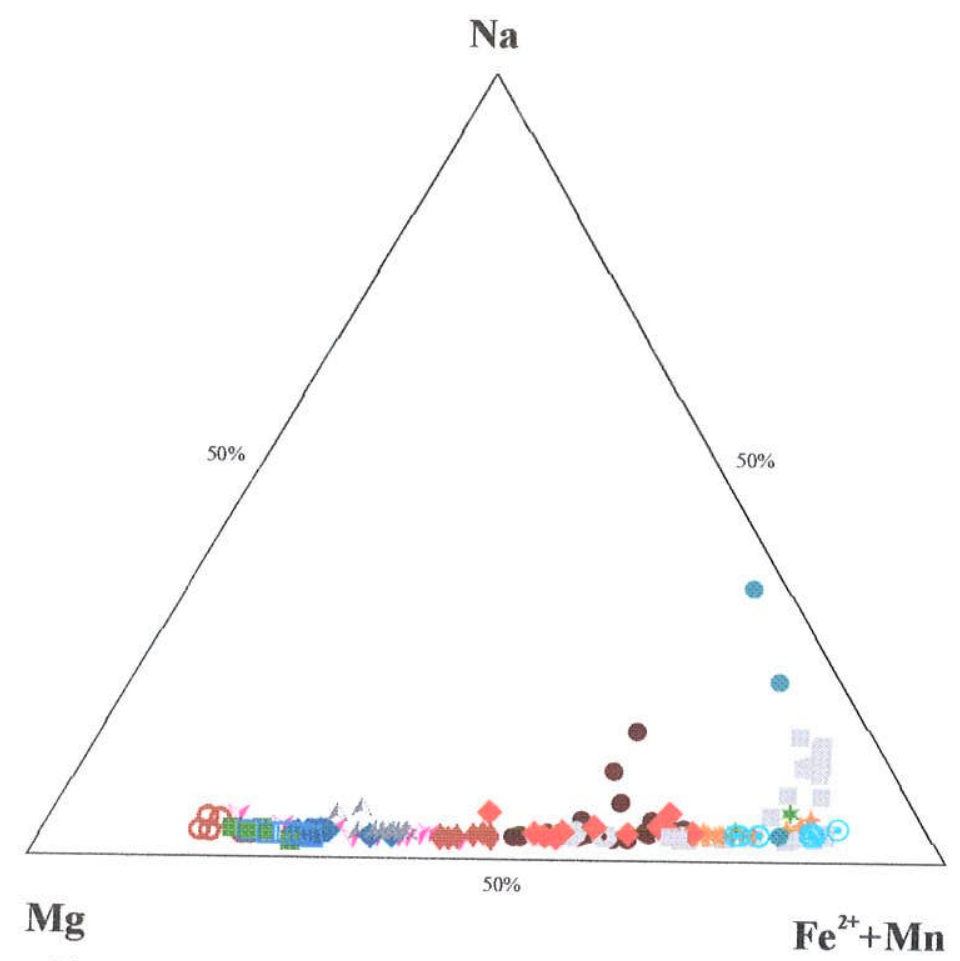

Figura V8. Diagrama catiônico $\left[\mathrm{Na} \times \mathrm{Mg} \times\left(\mathrm{Fe}^{2+}+\mathrm{Mn}\right)\right]$ para clinopiroxenio das fácies sieníticas, melasienítica, dioríticas e dos enclaves monzoniticos.
Sienito róseo grosso

- $\mathrm{Co}-3 \mathrm{D}$

- Co-51

Sienito róseo médio

$+\mathrm{Co}-4 \mathrm{~B}$

- Co-38

Sienito róseo fino

* Co-40B

Sienito verde grosso

Co-1

Co-50A

Sienito verde médio

( $\mathrm{Co}-5$

Melasienito

$\rightarrow$ Co-32D

Diorito/Rochas Hibridas

- $\mathrm{Co}-22$

-1. $\mathrm{Co}-32 \mathrm{H}$

Co-34B

$\square \quad \mathrm{Co}-4 \mathrm{D}$

o $\mathrm{Co}-50 \mathrm{~B}$

Enclave monzonítico

1. Co-6C 


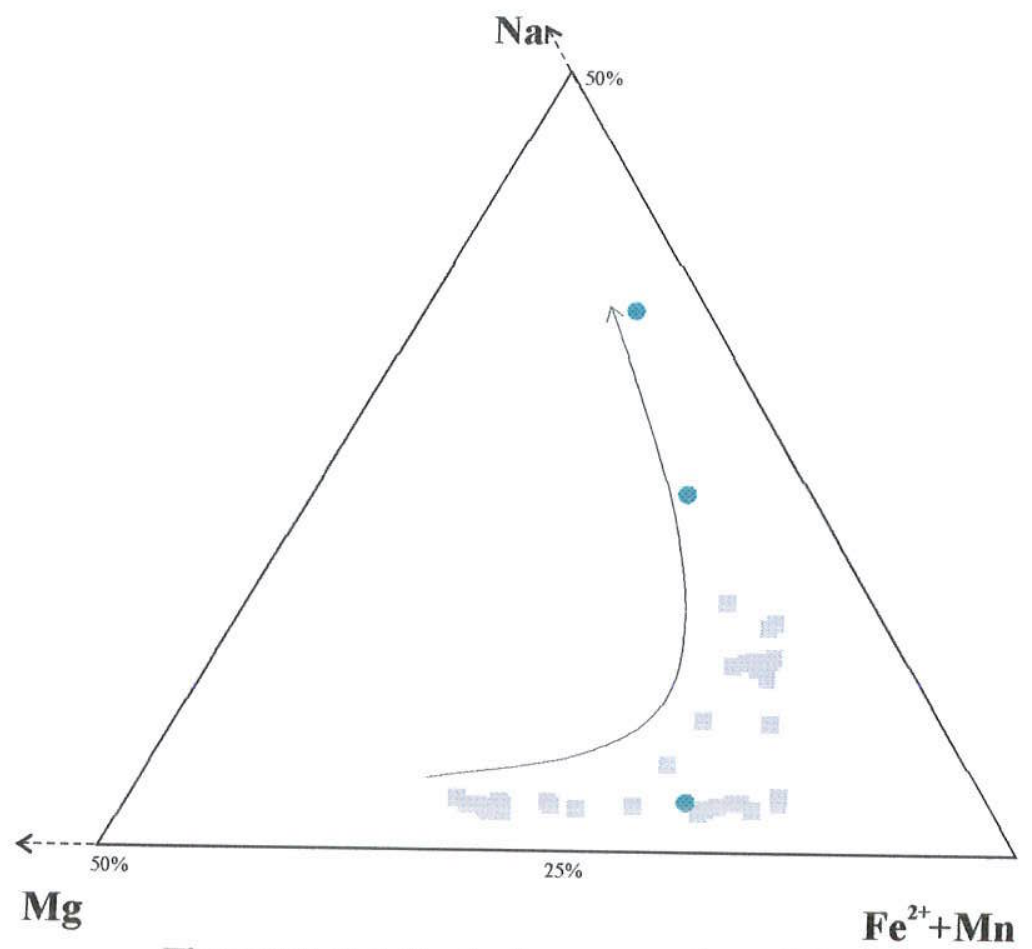

Sienito róseo grosso

- Co-3D

Sienito verde grosso

$\mathrm{Co}-1$

Figura V.9. Detalhe do diagrama cationico [Na $x \operatorname{Mg} x$ $\left.\left(\mathrm{Fe}^{2+}+\mathrm{Mn}\right)\right]$, apresentado na Figura V.8, ilustrando a tendência evolutiva do clinopiroxênio dos sienitos róseo e verde grosso.

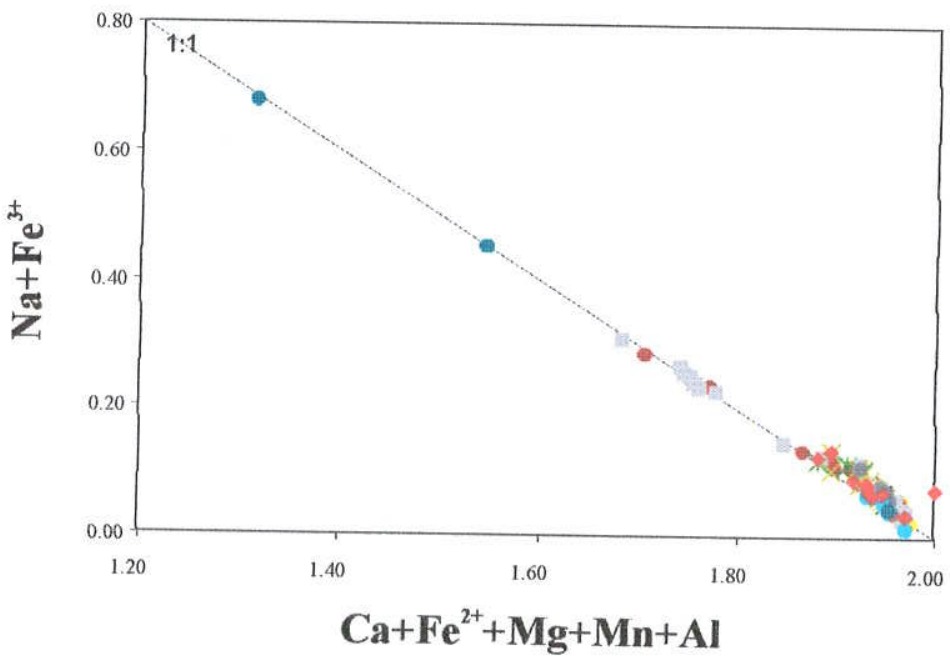

Figura V.10. Correlação entre as proporções cationicas $\left[\left(\mathrm{Ca}+\mathrm{Fe}^{2+}+\mathrm{Mg}+\mathrm{Mn}+\mathrm{Al}\right) \times\left(\mathrm{Na}+\mathrm{Fe}^{3+}\right)\right]$ para clinopiroxênios das fácies sieniticas e melasienitica.

Sienito róseo grosso

- Co-3D

- Co-51

Sienito róseo médio

Co-4B

- Co-38

Sienito róseo fino

* $\mathrm{Co}-40 \mathrm{~B}$

Sienito verde grosso

Co-1

- Co-50A

Sienito verde médio

- Co-5

Melasienito

Co-32D 

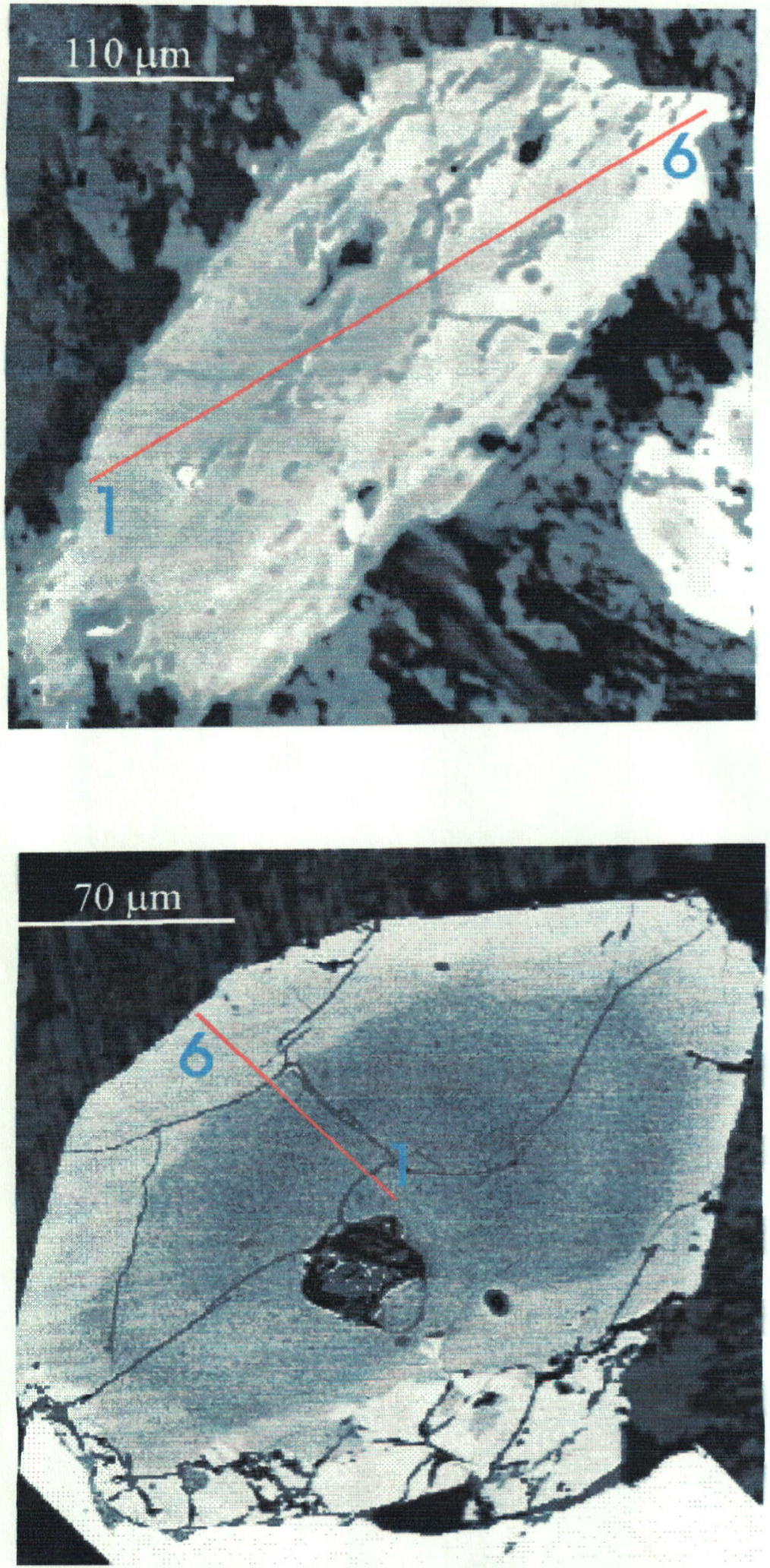

Figura V.11.Imagens de elétrons retro-espalhados, em modo composicional, de cristais de clinopiroxenio, ilustrando os perfis analiticos WDS efetuados e o número de análises. A: clinopiroxênio da fácies sienítica rósea média; $B$ : fácies sienítica rósea de granulação grossa, observar zonamento composicional normal, as bordas mostrando maior coeficiente de retroespalhamento por serem mais ricas em $\mathrm{Fe}$; $\mathrm{C}$ : fácies sienítica verde de granulação grossa; D: fäcies diorítica, observar leve zonamento oscilatório. 
C

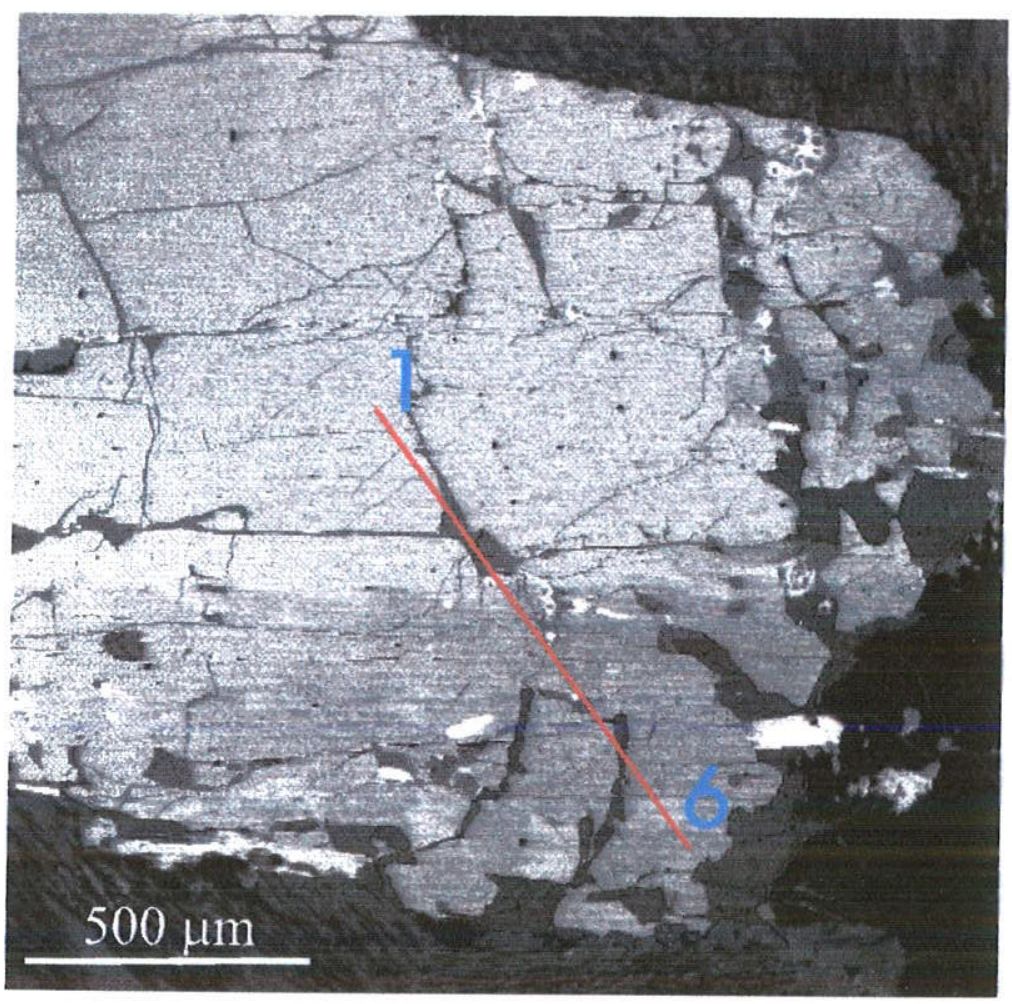

D

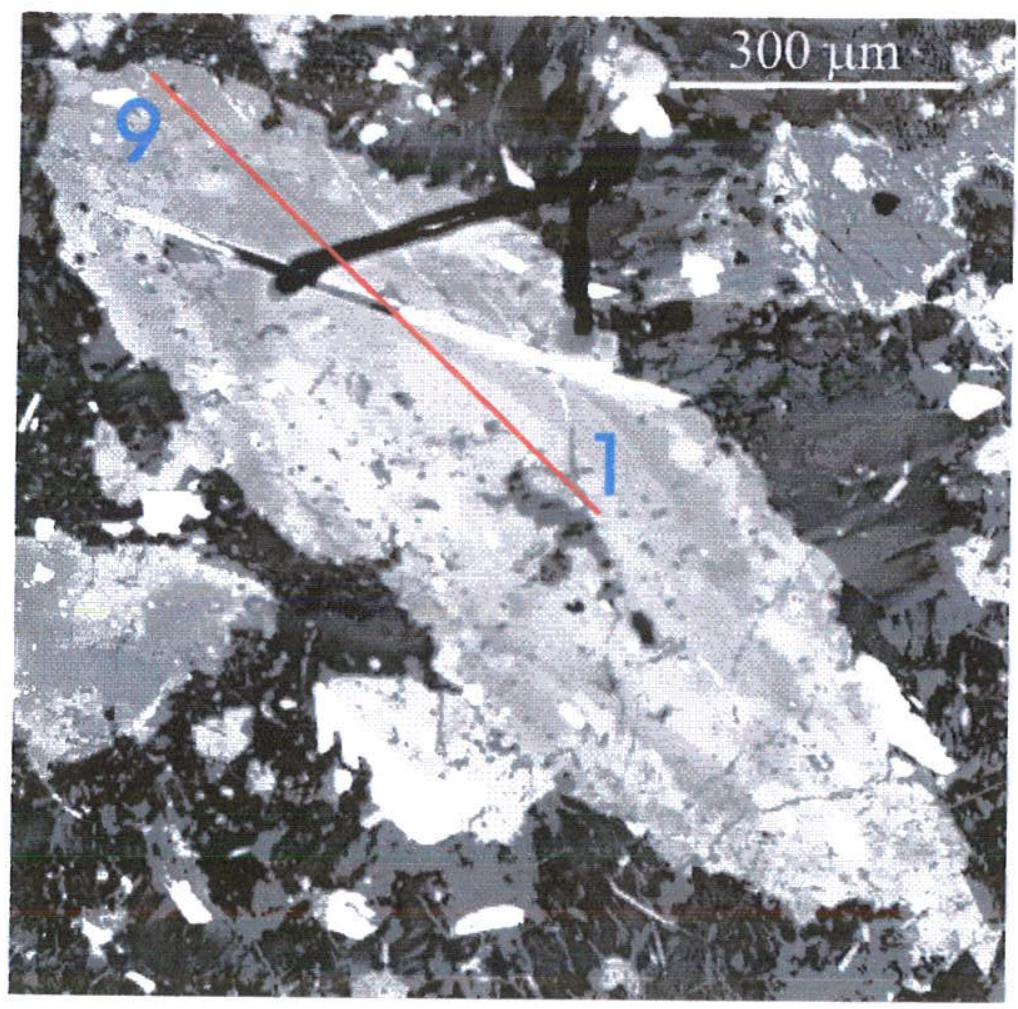

Figura V.11. Continuação 


\section{V.1.3 Anfibólio}

O anfibólio é também um mineral característico das rochas estudadas, estando presente, geralmente em quantidades significativas, em todas as variedades dioríticas, sieníticas e graníticas. Nas rochas sieniticas torna-se progressivamente mais importante nos tipos mais diferenciados (róseos) e nos granitos, onde o clinopiroxênio inexiste, é o mineral máfico mais importante. Na fácies melasienítica está tipicamente ausente.

\section{V.1.3.1 Texturas}

Nas fácies dioriticas o anfíbólio é intersticial, subidiomórfico e ocorre em agregados, junto a minerais opacos e clinopiroxênio, ou isoladamente. O pleocrósmo varia de tons verde-claros a bege, sem zonamentos composicionais identificados oticamente, e corresponde a uma variedade cálcica.

Nas fäcies sieníticas rósea e verde os grãos de anfíbólios podem ocorrer em agregados (cristais menores) ou isoladamente (grãos mais desenvolvidos). São subidiomórficos a idiomórficos, com zonamentos composicionais normais e/ou oscilatórios, evidenciados por um pleocroísmo que varia entre marrom-claro e bege no núcleo dos cristais a verde-escuro nas bordas (Figuras V.19Be V.19C). Alguns cristais apresentam núcleos corroídos de clinopiroxênio inclusos e também fino manteamento de biotita. Cristais tardios de anfibólio actinolítico ocorrem sob formas aciculares e em agregados fibro-radiados, estando sempre associados à biotita tardia e outros filossilicatos secundários existentes nestas rochas.

Nas fácies de composição granítica, ocorrem como cristais bem desenvolvidos, subidiomórficos a idiomórficos e isolados, aparecendo raramente em agregados. O pleocroísmo destes cristais é marcado por uma variação núcleo-borda, com o aumento do teor de sódio no grão, o que caracteriza, desta forma, um zonamento composicional (Figura V.19A). A cor dos grãos pode variar de verde ou castanho na porção central, até um azul-escuro nas bordas do cristal. 


\section{V.1.3.2 Quimismo}

O anfibólio presente nas variedades petrográficas do Maciço Corupá apresenta ampla gama de variações composicionais, observando-se composições primárias, magmáticas, desde cálcicas, a cálcio-sódicas e sódicas, bem como varidades ferromagnesianas, mais tipicamente pós-magmáticas (Figuras V.12A, V.12Be V.12C).

O anfibólio presente nas rochas dioríticas e hibridas corresponde principalmente a edenita (rochas dioriticas mais primitivas) e ferro edenita (rochas híbridas e enclave monzonítico) (Figura V.13B). Ferro-antofilita, tardia, aparece raramente em substiuição a clinopiroxênio (Figura V.13G). Nas rochas dioríticas e hibridas os valores mgł dos anfibólios cálcicos são sempre inferiores (em média de 10 a $30 \%$ relativo) aos do clinopiroxênio coexistente (Tabela V.3).

A correlação entre $\mathrm{Al}^{1 \mathrm{Ni}}$ e Soma_A+Al $\mathrm{Al}^{\mathrm{vi}}+\mathrm{Fe}^{3+}+0,5^{*} \mathrm{Ti}$ para os anfibólios das rochas dioríticas e híbridas é excelente (Figura V.I7) e muito próxima a $1: 1$, indicando que as variações composicionais mais relevantes dos cristais de anfibólio analisados correspondem a uma combinação entre os vetores edeníticos e tschermakíticos, descritos pelas seguintes equações, respectivamente :

$$
(\mathrm{Na}, \mathrm{K})^{\mathrm{A}}+\mathrm{Al}^{\mathrm{IV}} \Leftrightarrow[]^{\mathrm{A}}+\mathrm{Si}^{\mathrm{IV}}
$$

e

$$
\left(\mathrm{Mg}, \mathrm{Fe}^{2+}, \mathrm{Mn}\right)^{\mathrm{C}}+\mathrm{Si}^{\mathrm{IV}} \Leftrightarrow\left(\mathrm{Al}^{3+}, \mathrm{Fe}^{3+1}, 0,5 \mathrm{Ti}\right) \mathrm{C}+\mathrm{Al}^{\mathrm{IV}}
$$

em que [] representa uma vacância.

No diagrama correlacionando $\mathrm{Ca}+\mathrm{Al}^{\mathrm{IV}} \mathrm{com} \mathrm{Si}+\mathrm{Na}+\mathrm{K}$ (e.g. Giret et al., 1980) as rochas dioríticas mais típicas situam-se muito próximas ou na linha dos valores mínimos possiveis (Figura $V .18 B)$, enquanto as variedades híbridas e o enclave monzonítico já apresentam valores superiores de $\mathrm{Ca}+\mathrm{Al}^{\mathrm{IV}}$. Em média, este último parâmetro é algo menor, enquanto $\mathrm{Si}+\mathrm{Na}+\mathrm{K}$ é maior, quando 
comparados aos anfibólios presentes nas rochas monzodioríticas dos Granitos da Graciosa (Gualda, 2001).

Nas rochas sieníticas e quartzo-sieníticas, os anfibólios primários incluem variedades cálcicas e cálcio-sódicas (Figura V.12BB); anfíbólios sódicos não foram encontrados. As variedades cálcicas são principalmente ferro-actinolita e ferro-homblenda e, subordinadamente, ferro-edenita, com valores $m g \#$ inferiores a 0,30 , enquanto os tipos cálcio-sódicos são ferro-richterita e, em menor proporção, ferro-winchita, com mg\# menor que 0,22 (Figuras V.13A, V.13B e V.13C; Tabela V.3). Estes valores são em geral inferiores aos encontrados para o clinopiroxênio coexistente.

Nas rochas graníticas, o anfibólio presente varia de cálcio-sódico (ferro-richterita) a sódico (riebeckita/arvedsonita), este último predominante (Figuras V.I3D, V.I3E e V.13F), com valores

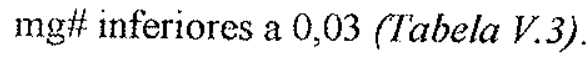

Nestes diagramas, o conjunto obtido de análises parece sugerir também uma situação similar à observada por Gualda (2001) para os Granitos da Graciosa, em que é observada uma certa lacuna que separa por um lado os anfibólios que variam contimuamente de cálcicos a cálcio-sódicos, presentes nas rochas sieniticas, dos que variam de cálcio-sódicos a sódicos nas rochas graníticas (Figura V.12A e V.12B).

Os anfibólios cálcicos, cálcio-sódicos e sódicos das rochas sieníticas e graníticas caracterizam-se também por teores significativos de $\mathrm{ZnO}$, que chegam a $2,0 \%$ em peso em algumas análises (Tabela V.3). Quantidades significativas, embora em média menores de $\mathrm{ZnO}$, aparecem em anfibólio das rochas híbridas e do enclave monzonítico, mas nos dioritos mais típicos os valores medidos são próximos ou abaixo do limite de detecção (Tabela V.3).

O anfibólio pós-magmático incolor a levemente esverdeado que aparece intersticialmente em alguns sienitos, junto com filossilicatos e outros materiais não identificados, é relativamente homogêneo e corresponde a ferromantofilita (Fïgura V.I3(j). 
$\mathrm{O}$ anfibólio primário dos sienitos e granitos mostra variações composicionais relevantes (Tabela V.3) que, por vezes, ocorrem em um mesmo cristal, através de zonamentos químicos normais e/ou oscilatórios. As variações químicas observadas são decorrentes da atuação de diversos mecanismos de substituições acopladas, que podem ser resumidos na seguinte equação expandida:

$$
(\mathrm{Na}, \mathrm{K})^{\mathrm{A}}+\mathrm{Si}^{\mathrm{N}}+\mathrm{Ca}^{\mathrm{B}}+\mathrm{R}^{2+} \Leftrightarrow[]^{\mathrm{A}}+\mathrm{Na}^{\mathrm{B}}+\mathrm{Al}^{3 \mathrm{~V}}+\mathrm{Fe}^{3+}
$$

em que [ ] representa uma vacância e $\mathrm{R}^{2+}=\mathrm{Mg}+\mathrm{Fe}^{2++}+\mathrm{Mn}(+\mathrm{Zn})$. O diagrama apresentado na Fïgura $V .14$ mostra elevada correlação negativa entre estes parâmetros, demonstrando que a reação acima foi determinante para as variações composicionais apresentadas por estes minerais.

As variações composicionais destes anfibólios são também bem marcadas nos diagramas das Figuras V.18A (e.g. Giret et al., 1980) e V.15, em que representam-se os parâmetros Ca+Al ${ }^{I V} \mathrm{e}$ $(\mathrm{Na}+\mathrm{K}) / \mathrm{Al}$ ws $\mathrm{Si}+\mathrm{Na}+\mathrm{K}$.

No primeiro diagrama (Figura V.18A), as composições do anfibólio das rochas sieníticas são contínuas e mostram uma tendência evolutiva do tipo barroisita $\rightarrow$ winchita $\rightarrow$ richterita. Os pontos analíticos representativos das rochas graníticas são algo dispersos entre riebeckita e arfvedsonita, provavelmente devido as incertezas na avaliação do $\mathrm{Fe}^{3+}$; de qualquer forma as análises das variedades mais evoluídas correspondem a arfvedsonita. Esta tendência difere significativamente da encontrada para as associações alcalina I e II dos Granitos da Graciosa (Gualda, 2001), não se observando uma lacuna clara entre os termos cálcicos a cálcio-sódicos e cálcio-sódicos a sódicos e nem as tendências mais tipicamente oxidantes, no primeiro caso, ou uma trajetória para termos mais evoluídos richteríticos no segundo.

$\mathrm{O}$ parâmetro $(\mathrm{Na}+\mathrm{K}) / \mathrm{Al}$ em minerais máficos correlaciona-se diretamente com o Índice Agpaítico das rochas (Giret et al., 1980) (Figura V.15). O aumento contínuo e progressivo deste parâmetro no grupo das rochas sieníticas dos núcleos para as bordas de cristais individuais de uma mesma amostra e, entre diferentes amostras, das menos para as mais diferenciadas (Figura V.15) sugere uma evolução magmática simples e contínua. As análises representativas da fácies granítica 
situam-se no extremo mais agpaítico do diagrama e, contrastando com o que sugere o diagrama relacionando Si e $(\mathrm{Na}+\mathrm{K})$ (Figura V.16), em aparente continuidade com a tendência observada para as rochas sieníticas, sugerindo que sienitos e granitos devam fazer parte da mesma linhagem de evolução magmática, com crescente alcalinidade. 


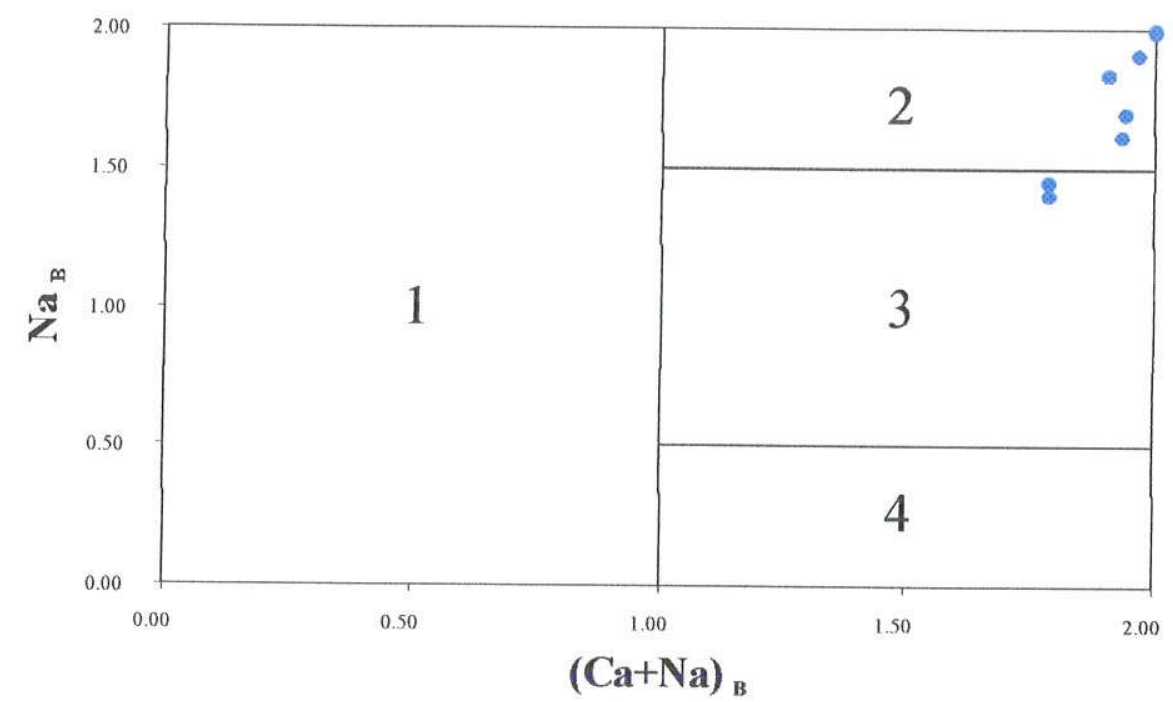

$\boldsymbol{B}$

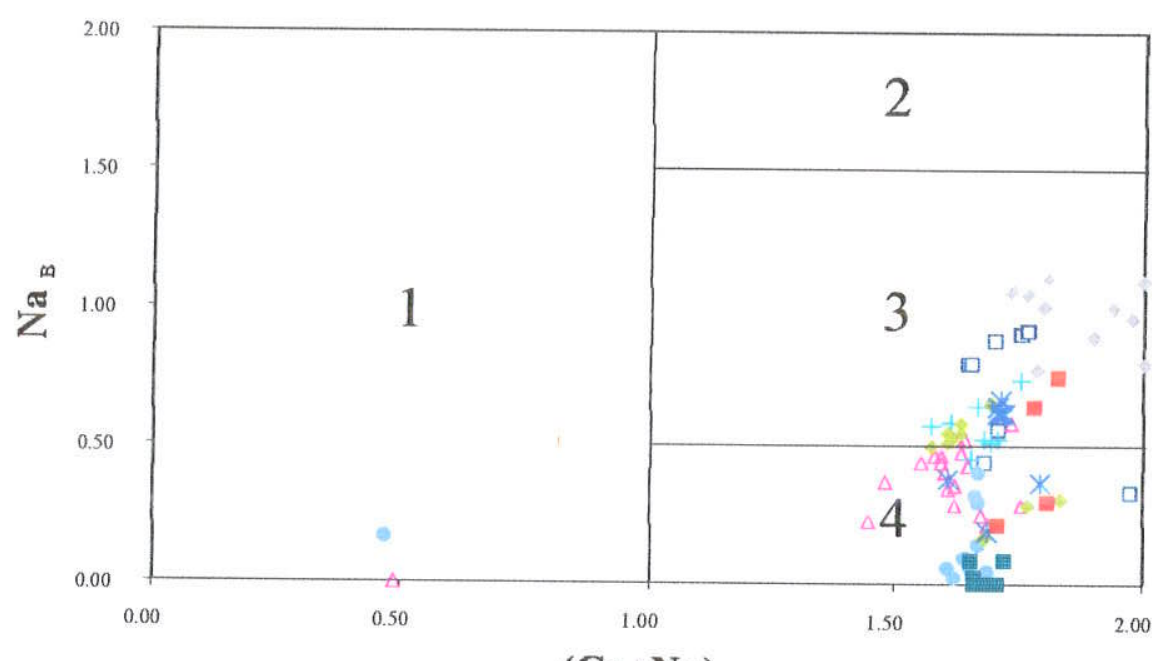

$(\mathrm{Ca}+\mathrm{Na})_{\text {B }}$

C

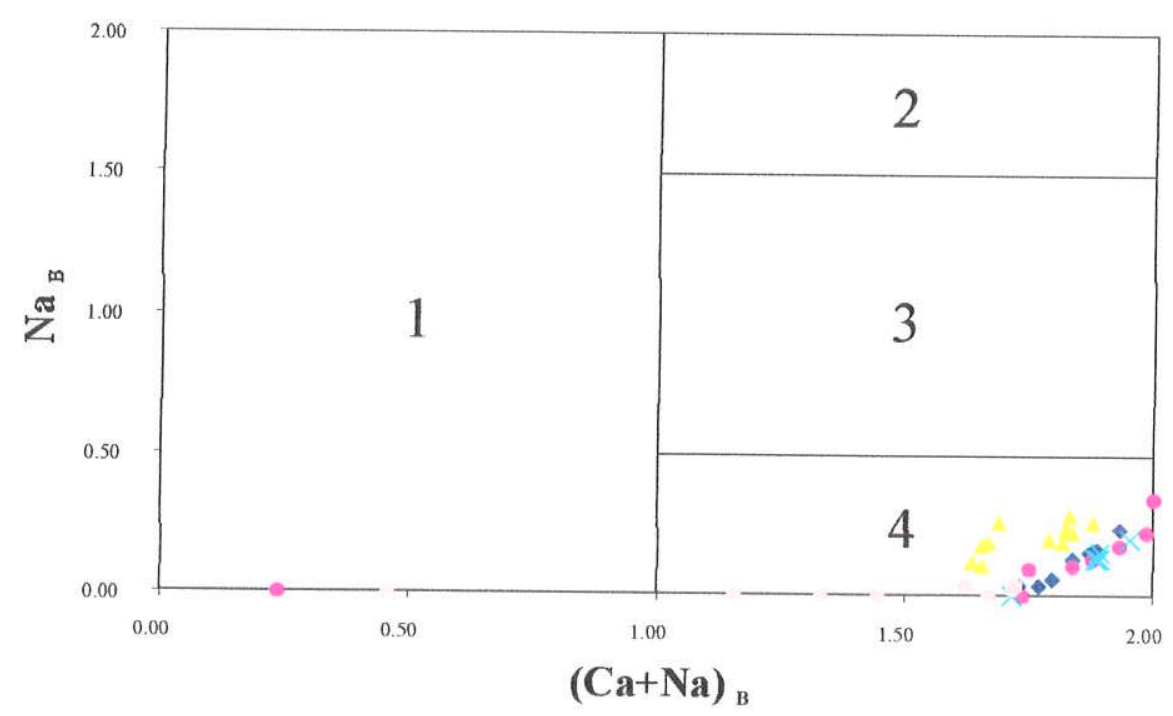

Figura V.12. Diagramas catiônicos $\left[(\mathrm{Ca}+\mathrm{Na})_{B} \times \mathrm{Na}_{B}\right]$ para classificação dos anfibólios (Leake et al., 1997) das fácies petrográficas (A) granítica, (B) sieniticas e (C) dioríticalrochas hibridas e enclaves monzoniticos.

Campos: 1- Mg-Fe-Mn-Li; 2- Anfibólios sódicos; 3- Anfibólios cálcico-sódicos; 4- Anfibólios cálcicos. 


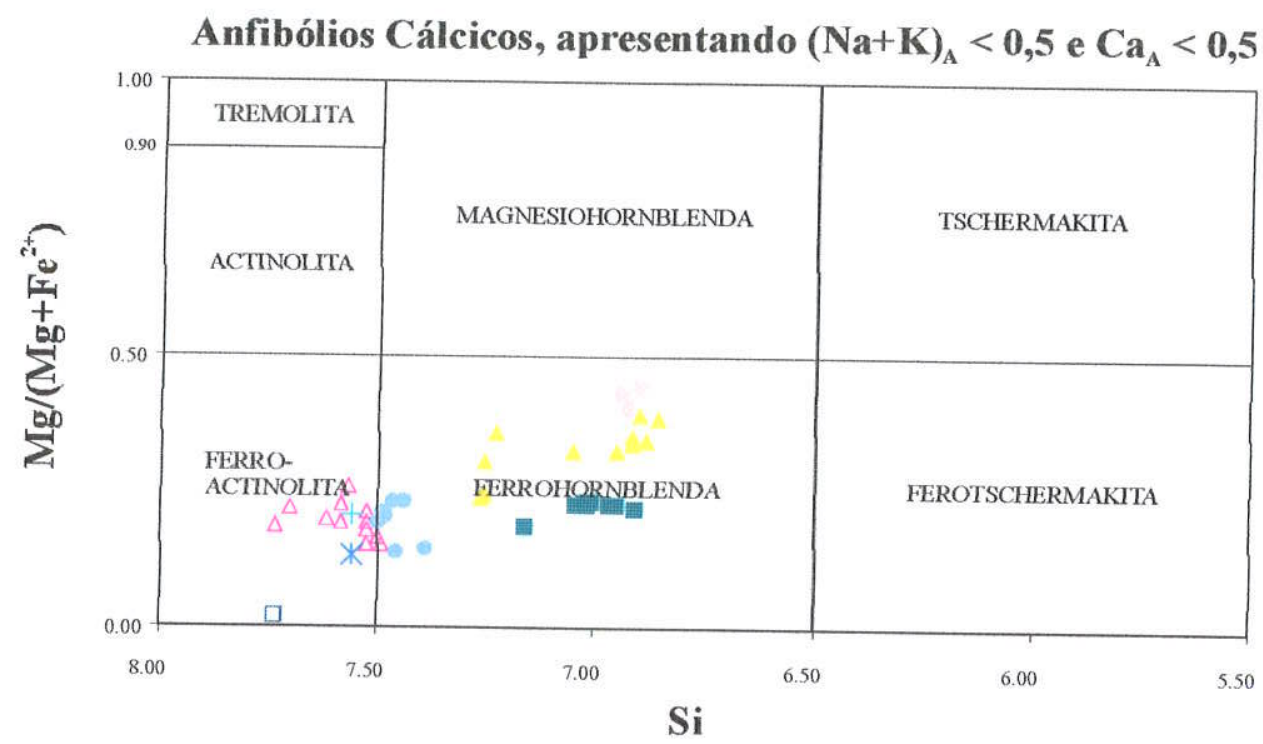

B

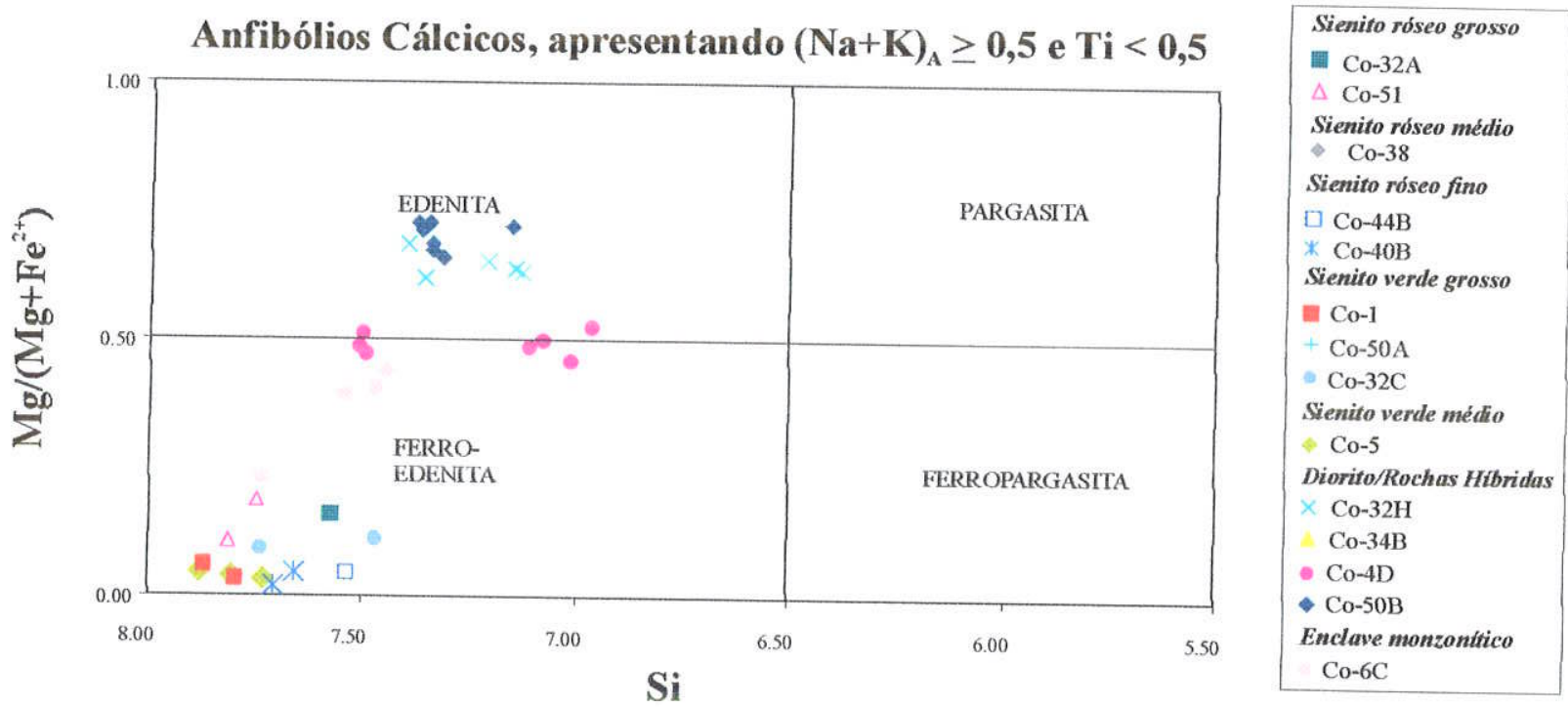

Anfibólios Cálcico-sódicos, apresentando $(\mathrm{Na}+\mathrm{K})_{\mathrm{A}}<0,5$

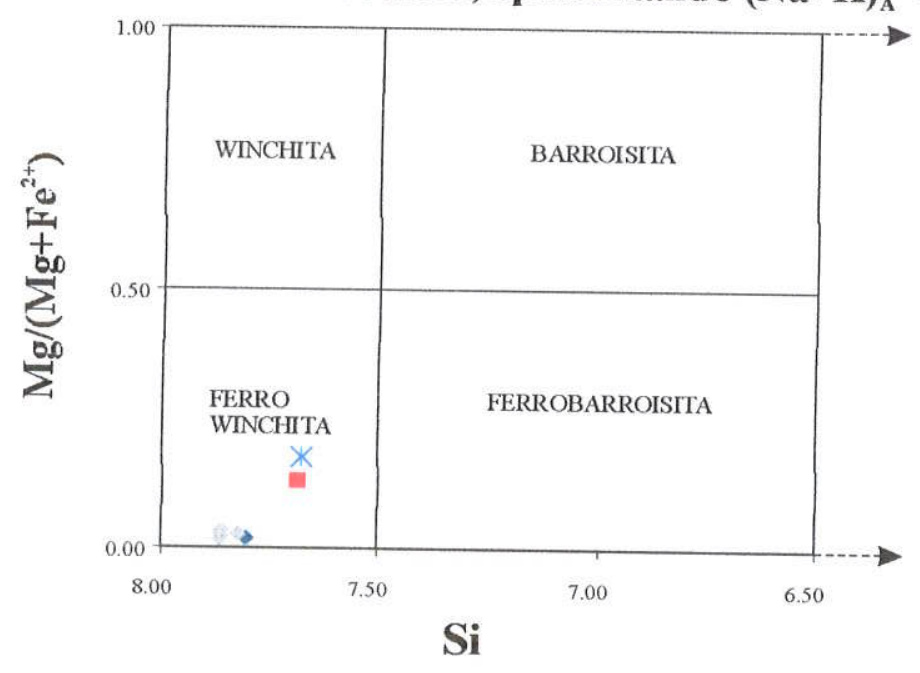

Figura V.13. Diagramas cationicos [Si $\left.x \mathrm{Mg} /\left(\mathrm{Mg}+\mathrm{Fe}^{2+}\right)\right]$ (Leake et al., 1997) para classificação dos anfibólios das fácies petrográficas do Maciço Corupá. 
$D$

Anfibólios Cálcico-sódicos, apresentando $(\mathrm{N} a+K)_{\Lambda} \geq 0,5$

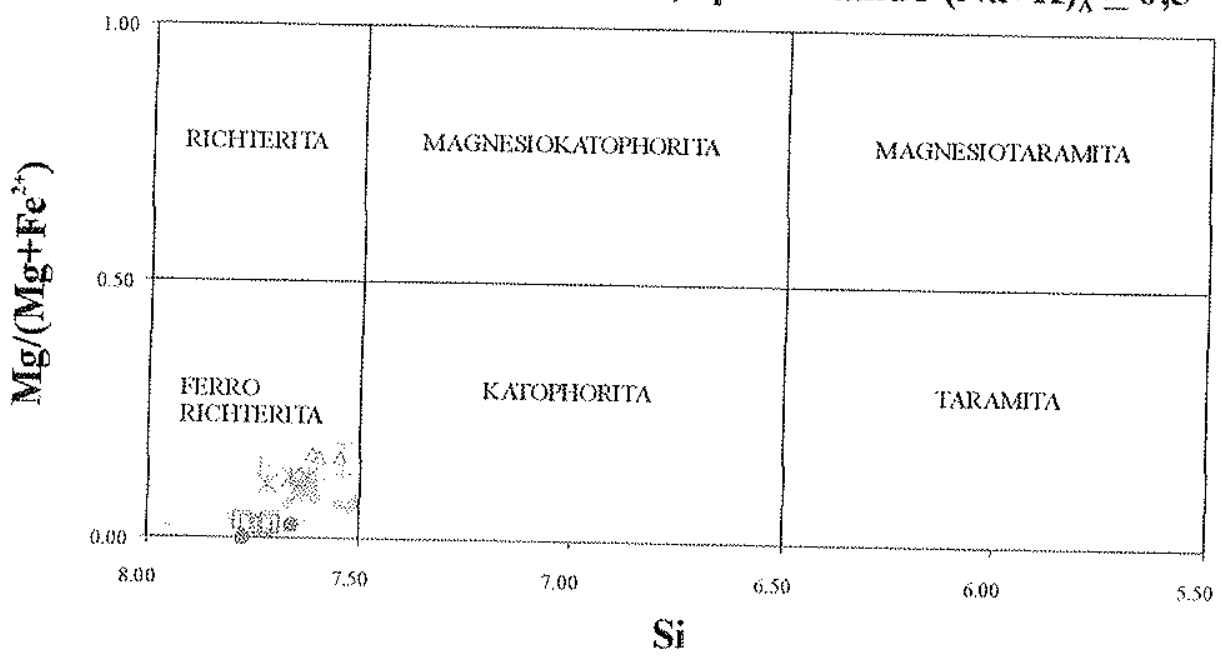

$E \quad$ Anfibólios Sódicos, apresentando $(\mathbb{N a}+\mathbf{K})_{A}<0,5, \mathbf{A l}_{\mathrm{V} 1}<\mathrm{Fe}^{3+}$ e $\mathbf{M g}>\mathrm{Mn}^{2+}$

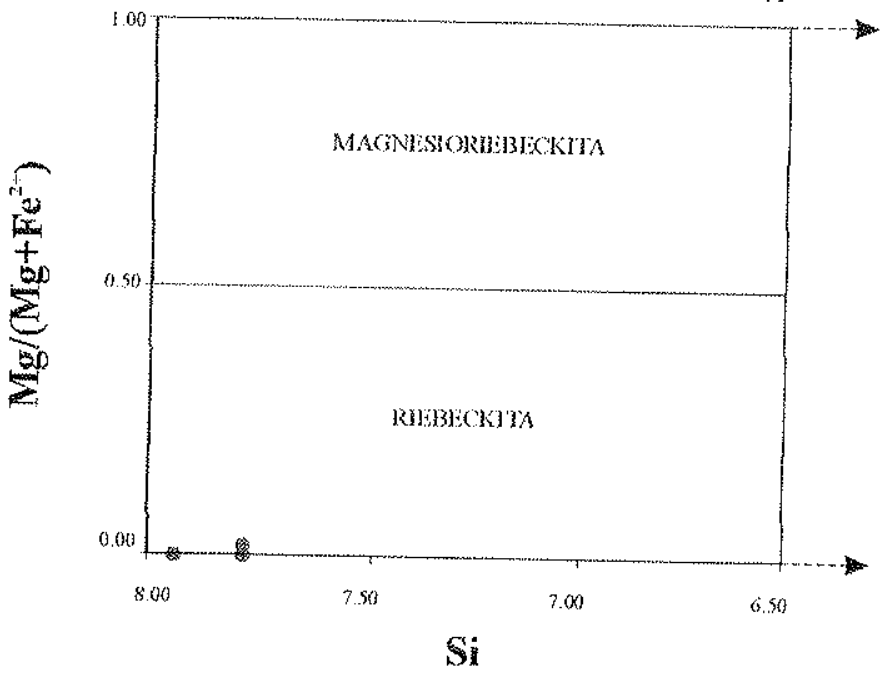

$F \quad$ Anfibólios Sódicos, apresentando $(\mathrm{Na}+\mathrm{K})_{\mathrm{A}} \geq 0,5, \mathrm{Al}_{\mathrm{V} 1}<\mathrm{Fe}^{3+}$ e $\mathrm{Mg}>\mathrm{Mn}^{2+}$

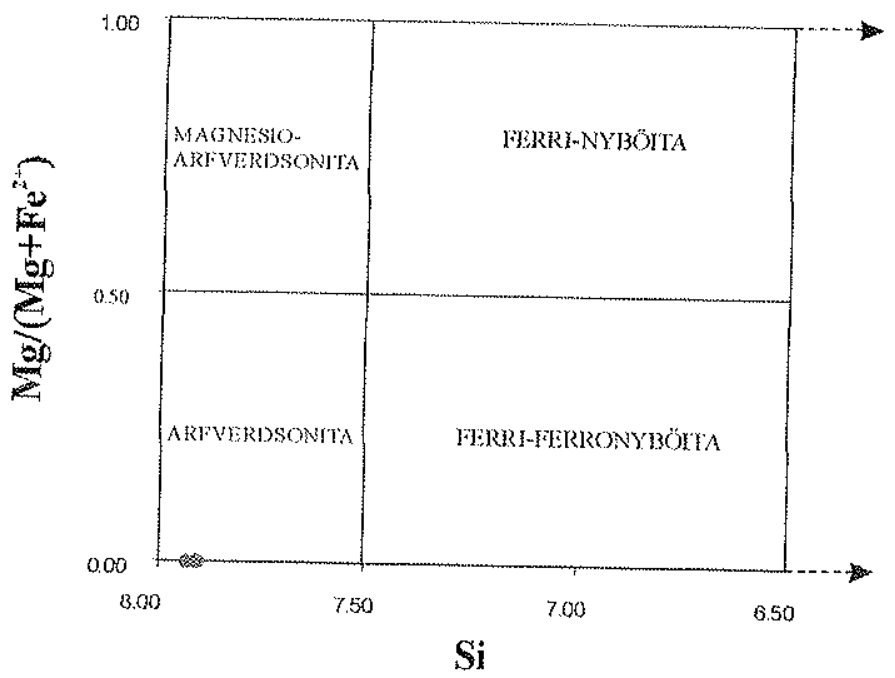

Figura V. 3. Continuaģăo. 


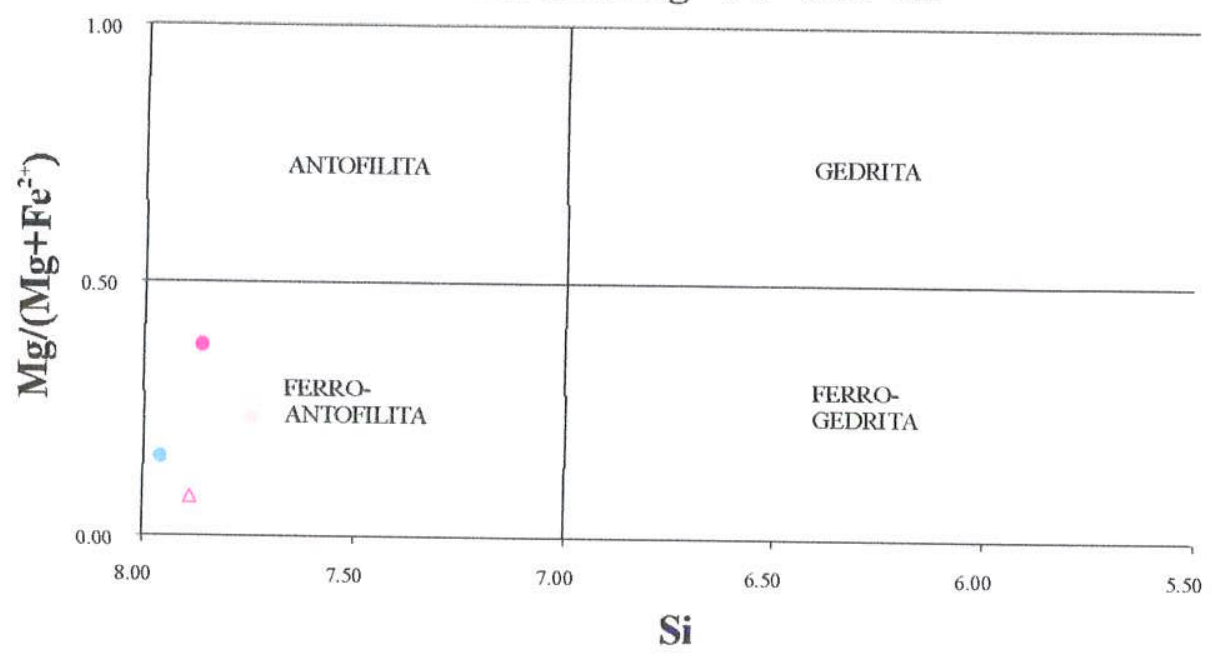

Figura V.13. Continuação.

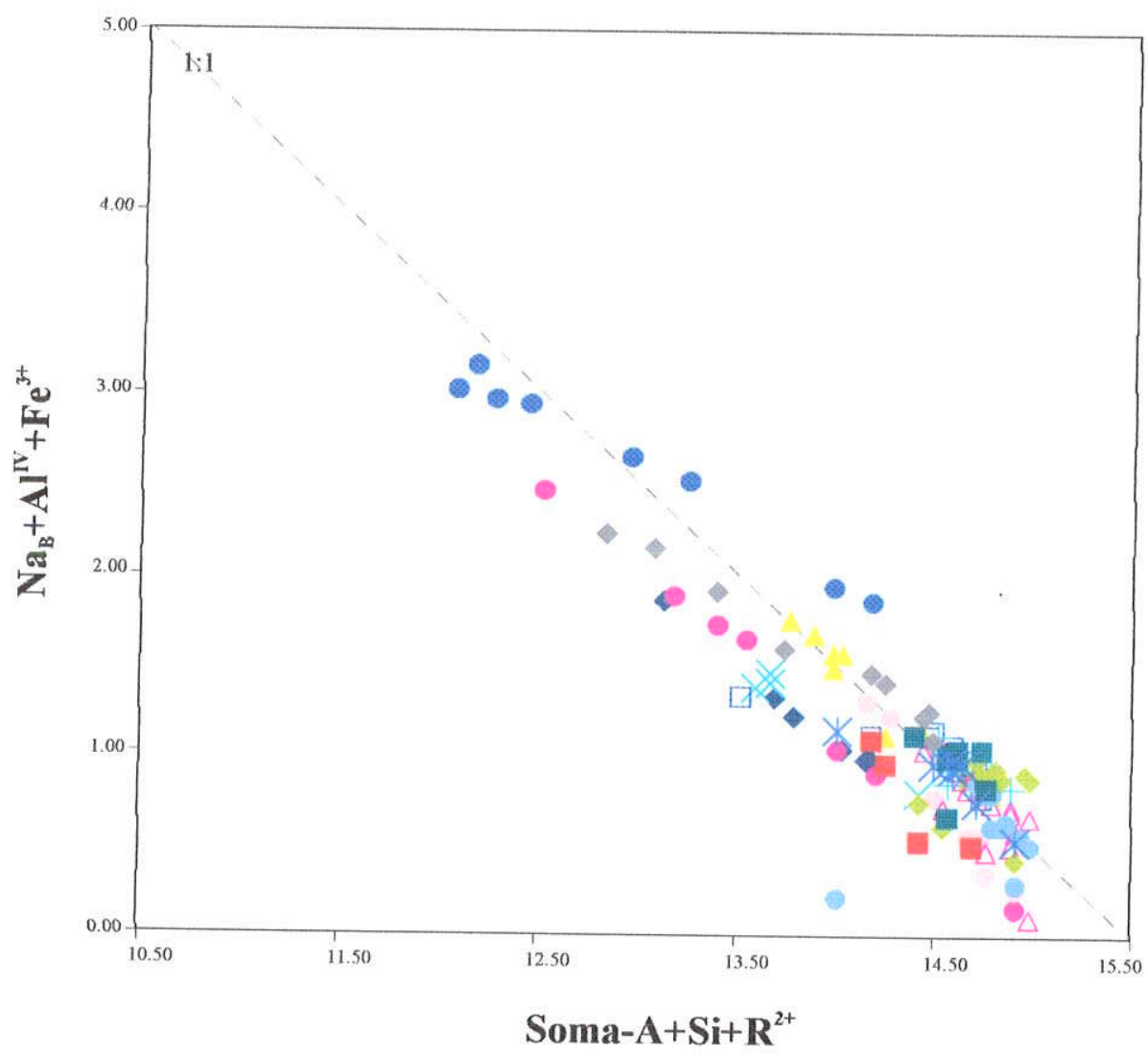

\begin{tabular}{|l|}
\hline Granito \\
Co-2A \\
Sienito róseo grosso \\
Co-32A \\
$\triangle$ Co-51 \\
Sienito róseo médio \\
Co-38 \\
Sienito róseo fino \\
$\square$ Co-44B \\
*o-40B \\
Sienito verde grosso \\
Co-1 \\
+ Co-50A \\
Co-32C \\
Sienito verde médo \\
Co-5 \\
Diorito/Rochas Hibridas \\
$\times$ Co-32H \\
Co-34B \\
Co-4D \\
Co-50B \\
Enclave monzont́ico \\
Co-6C \\
\hline
\end{tabular}

Figura V.14. Correlação entre proporções catiônicas [(Soma$\left.\left.A+S i+R^{2}\right) \times\left(N_{B}+A l^{T+}+F^{3+}\right)\right]$ dos anfibólios das fácies granitica, sieniticas, dioritica/rochas hibridas e enclaves monzoniticos.

$$
\left(\mathrm{R}^{2+}=\text { cátions bivalentes }\right) \text {. }
$$




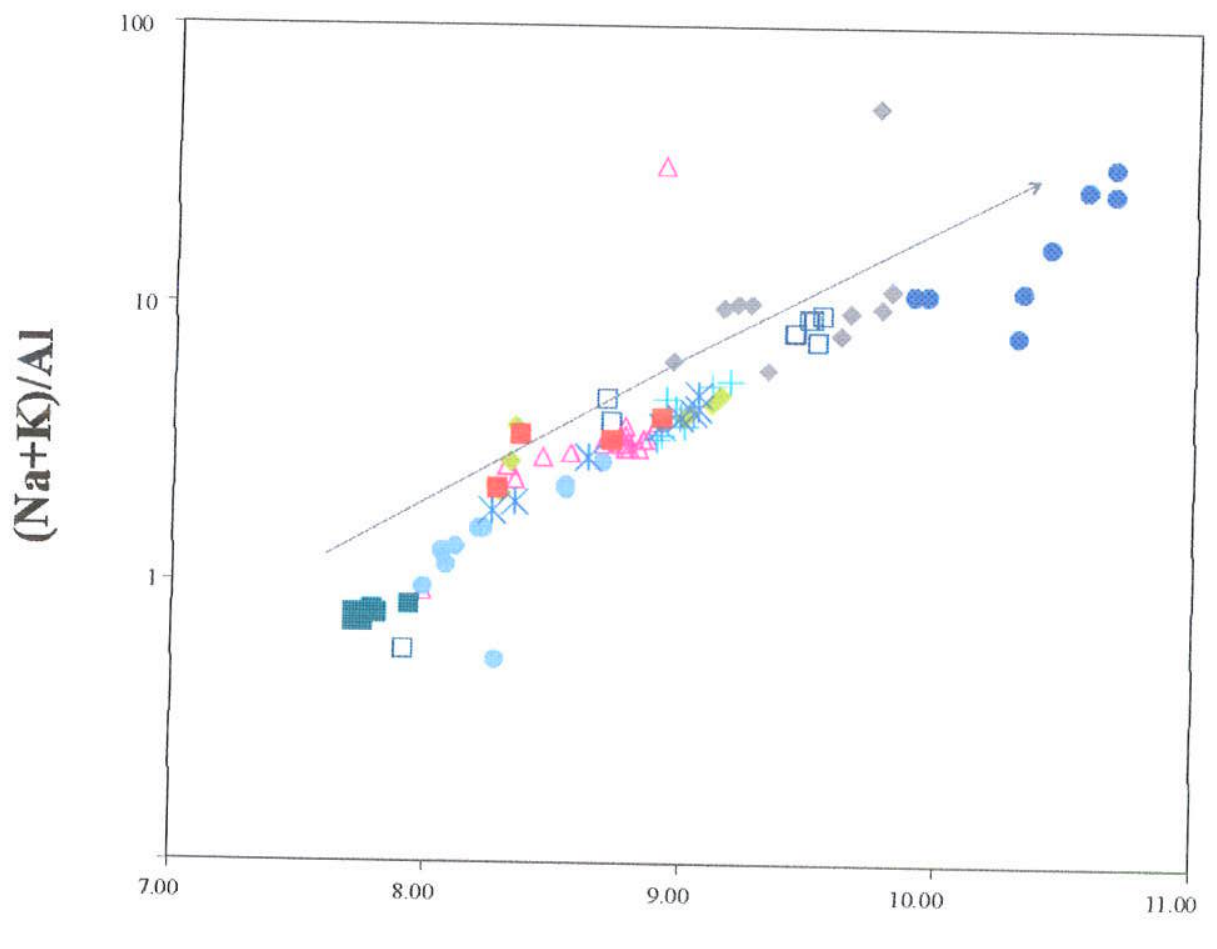

\section{$\mathrm{Si}+\mathrm{Na}+\mathrm{K}$}

Figura V.15. Correlação entre proporções catiônicas [Si+Na+Kx $(\mathrm{Na}+\mathrm{K}) / \mathrm{Al}]$ dos anfibólios das fácies granítica e sieniticas. 


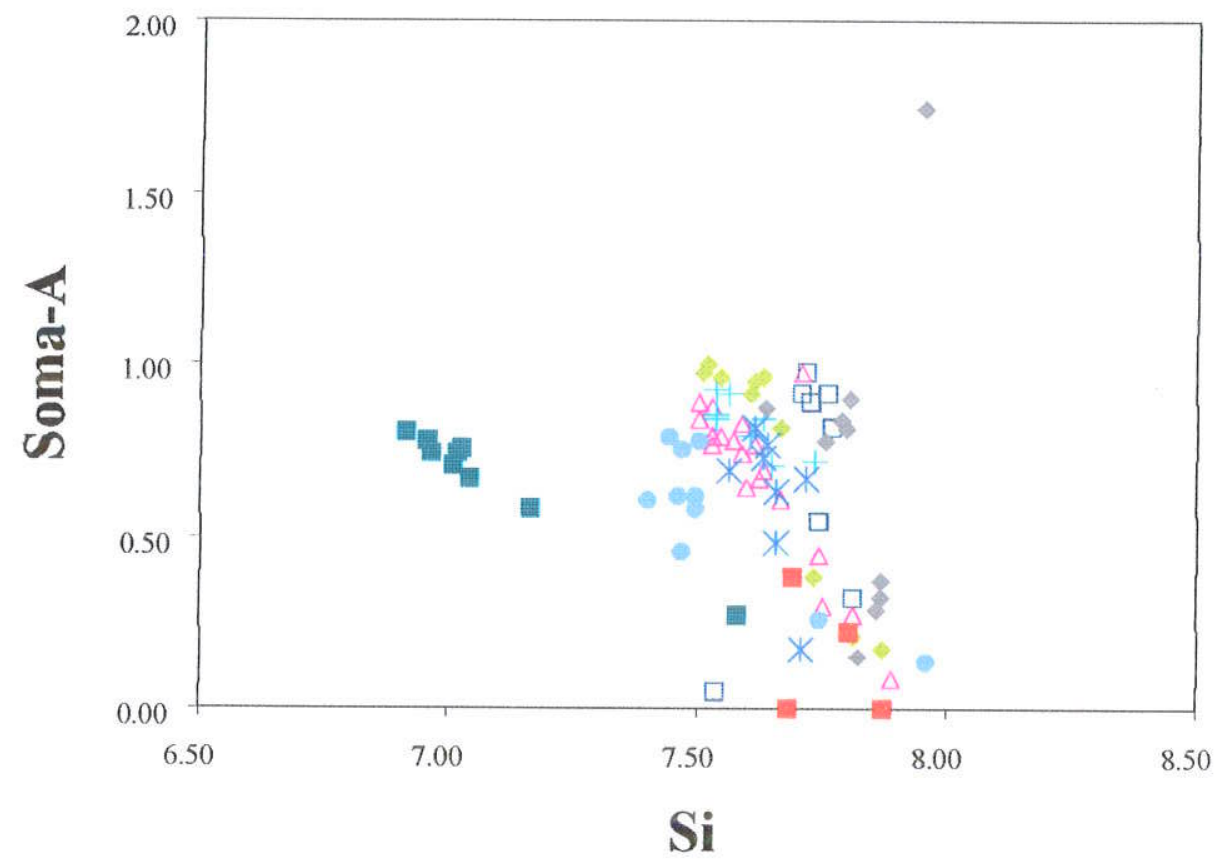

Sienito róseo grosso

음 $\mathrm{Co}-32 \mathrm{~A}$

$\triangle \mathrm{Co}-51$

Sienito róseo médio - Co-38

Sienito róseo fino

$\square \mathrm{Co}-44 \mathrm{~B}$

* $\mathrm{Co}-40 \mathrm{~B}$

Sienito verde grosso

an-1

$+\mathrm{Co}-50 \mathrm{~A}$

- Co-32C

Sienito verde médio Co-5

Figura V.16. Correlação entre proporções cationicas (Si x SomaA) em anfibólios das fácies sieniticas. 


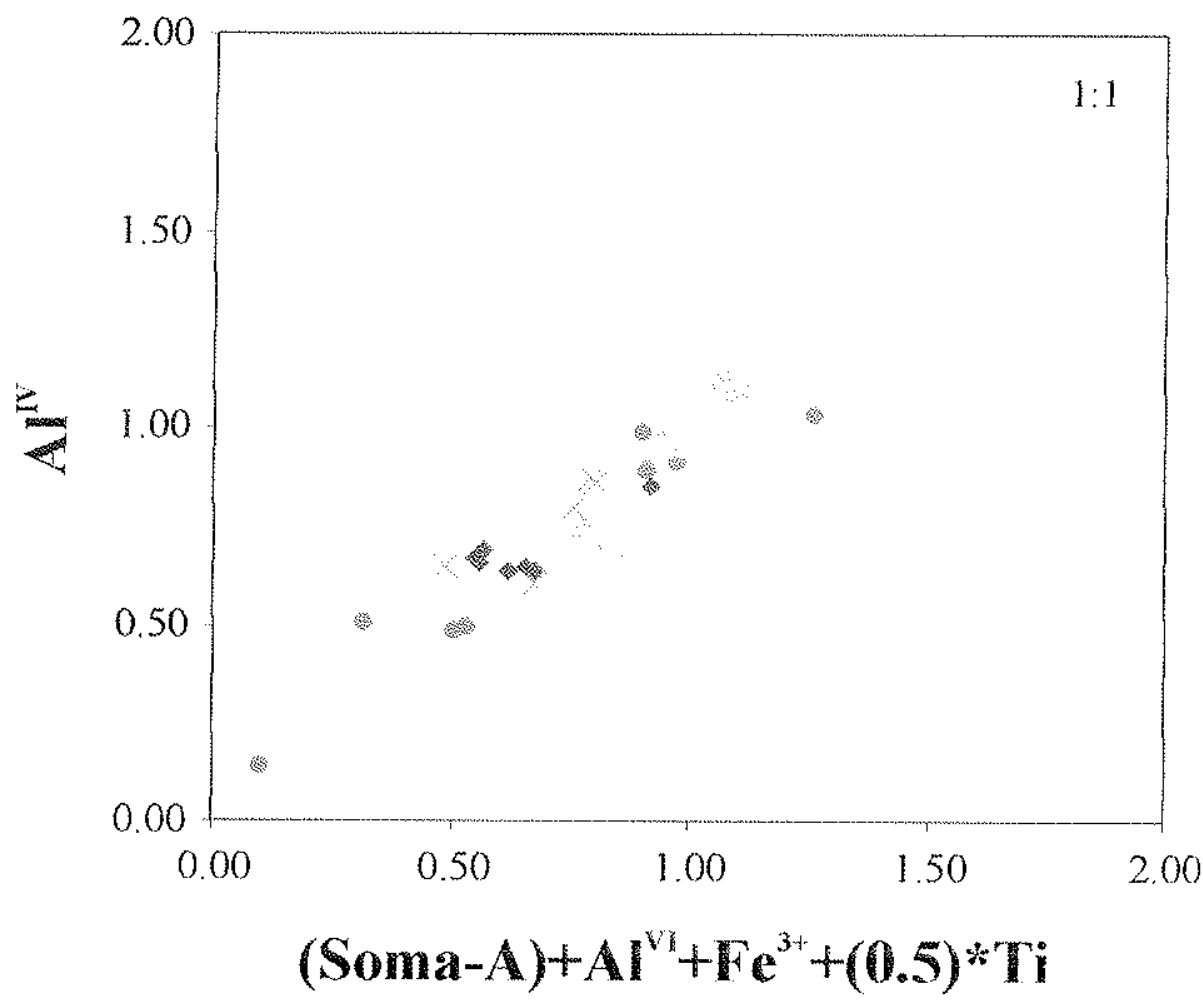

Diorito/Rochas Hibridus

Co-32H

(.) $3-34.3$

\% (on 41$)$

Co-5013

Enclave monzontico

Co- $6 \mathrm{C}$

Figura V.17. Correlação entre as proporçoes cationicas $\left[(\right.$ Soma-A $\left.\left.)+A l^{n}+F e^{3+}+(0.5) * T i x A l^{\prime \prime}\right)\right]$ dos anfibólios das fácies dionitica/rochas hibridas enclaves monzoniticos. 


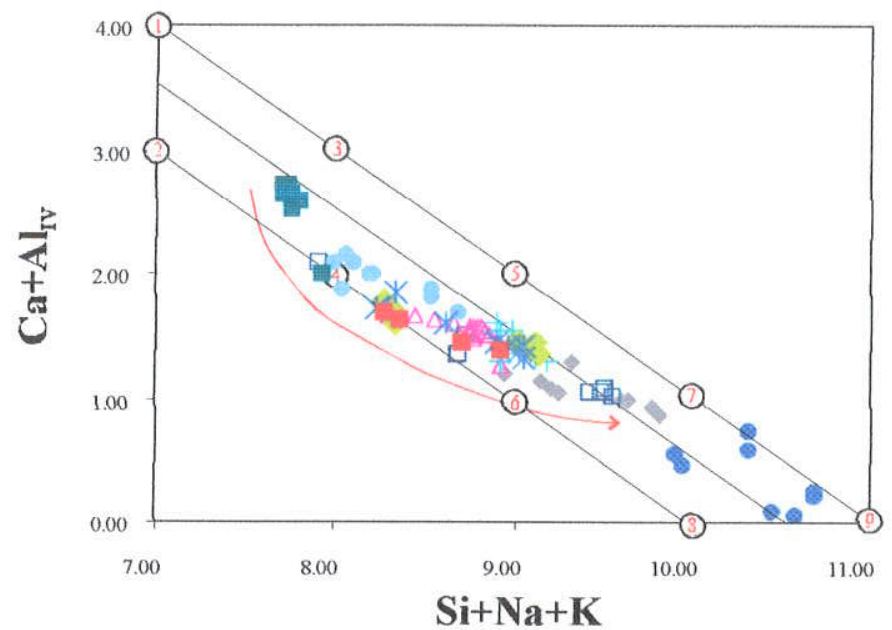

$\boldsymbol{B}$

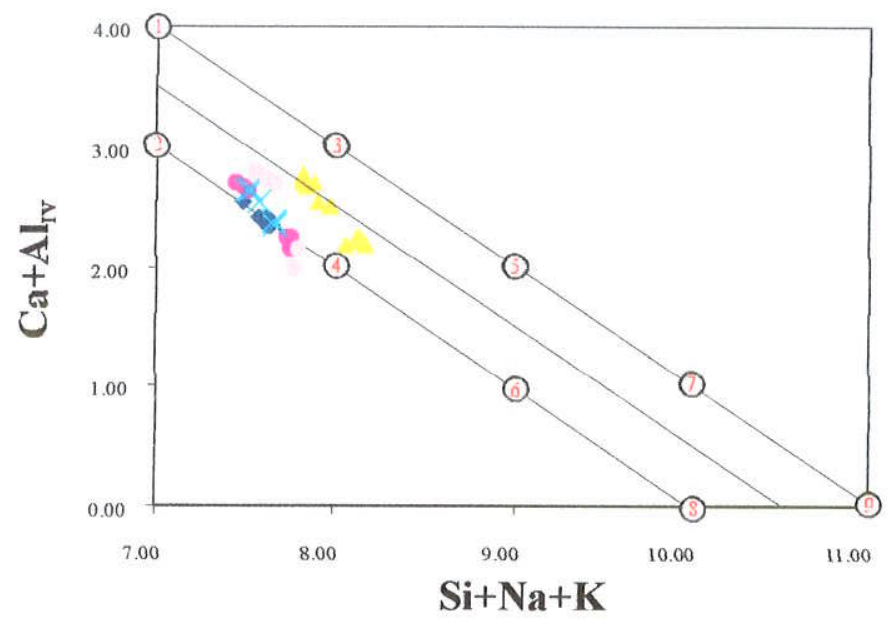

- Co-2A

Sienito róseo grosso

대를 $\mathrm{Co}-32 \mathrm{~A}$

$\triangle \mathrm{Co}-51$

Sienito róseo médio

$\$ \mathrm{Co}-38$

Sienito róseo fino

$\square \mathrm{Co}-44 \mathrm{~B}$

* $\mathrm{Co}-40 \mathrm{~B}$

Sienito verde grosso

a $\mathrm{Co}-1$

$+\mathrm{Co}-50 \mathrm{~A}$

- $\mathrm{Co}-32 \mathrm{C}$

Sienito verde médio

$\$ \mathrm{Co}-5$

Diorito / Rochas Hibridas

Co-32H

Co-34B

- Co-4D

- $\mathrm{Co}-50 \mathrm{~B}$

Enclave monzonúico $\mathrm{Co}-6 \mathrm{C}$

Figura V.18. Correlação entre proporções cationicas $\left.\left(\mathrm{Si}+\mathrm{Na}+\mathrm{K} \times \mathrm{Ca}+\mathrm{Al}^{\mathrm{N}}\right)\right]$ para anfibólios das fácies (A) granitica e sienitica, (B)

diorítica/rochas híbridas e enclaves monzoniticos.

1- Hastingsita; 2- Hornblenda; 3- Edenita ou

Taramita; 4- Barroisita; 5- Katophorita; 6-

Winchita; 7-Richterita; 8- Riebeckita; 9-

Arfvedsonita.

(A): Trajetória evolutiva do anfibólio das rochas sieníticas é destacada em vermelho. 

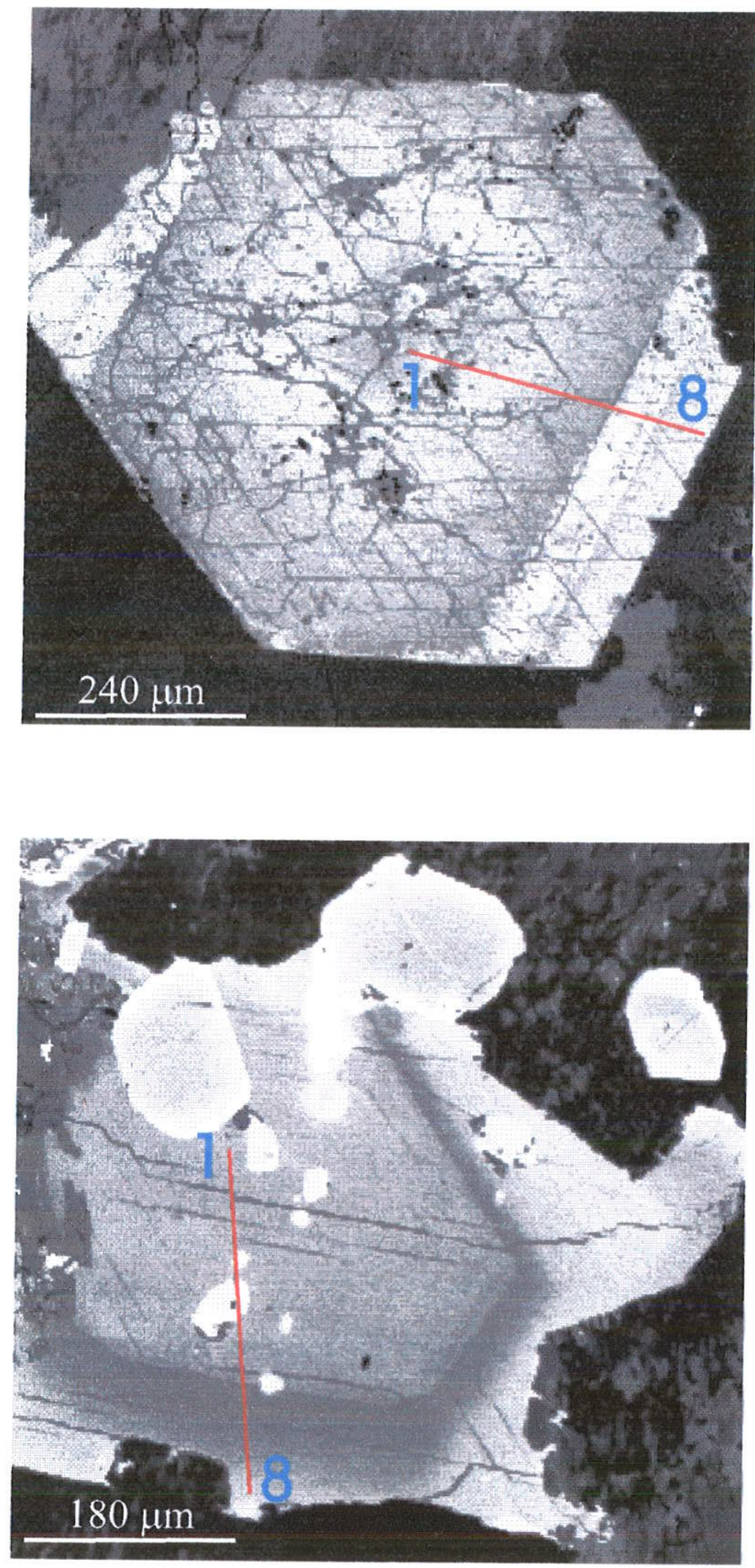

Figura V.19. Imagens de elétrons retro-espalhados em modo composicional de cristais de anfibólio e perfis analíticos WDS efetuados e o número de análises em cada perfil. A: fácies granitica tipica, observar bordas adicionadas mais ricas em Fe; B: fácies sienítica rósea de granulação grossa, observar núcleo homogêneo, com borda intermediária com fino zonamento recorrente e borda externa relativamente homogênea, algumas inclusões de ilmenita e acessórios; C: fácies sienítica verde de granulação grossa, observa-se núcleo mais homogêneo, borda intermediária com zonamento recorrente e borda externa mais homogênea e clara, mais rica em $\mathrm{Fe}$; $D$ : fácies hibrida, monzonitica com padrão de zonamento similar ao caso acima. 
C

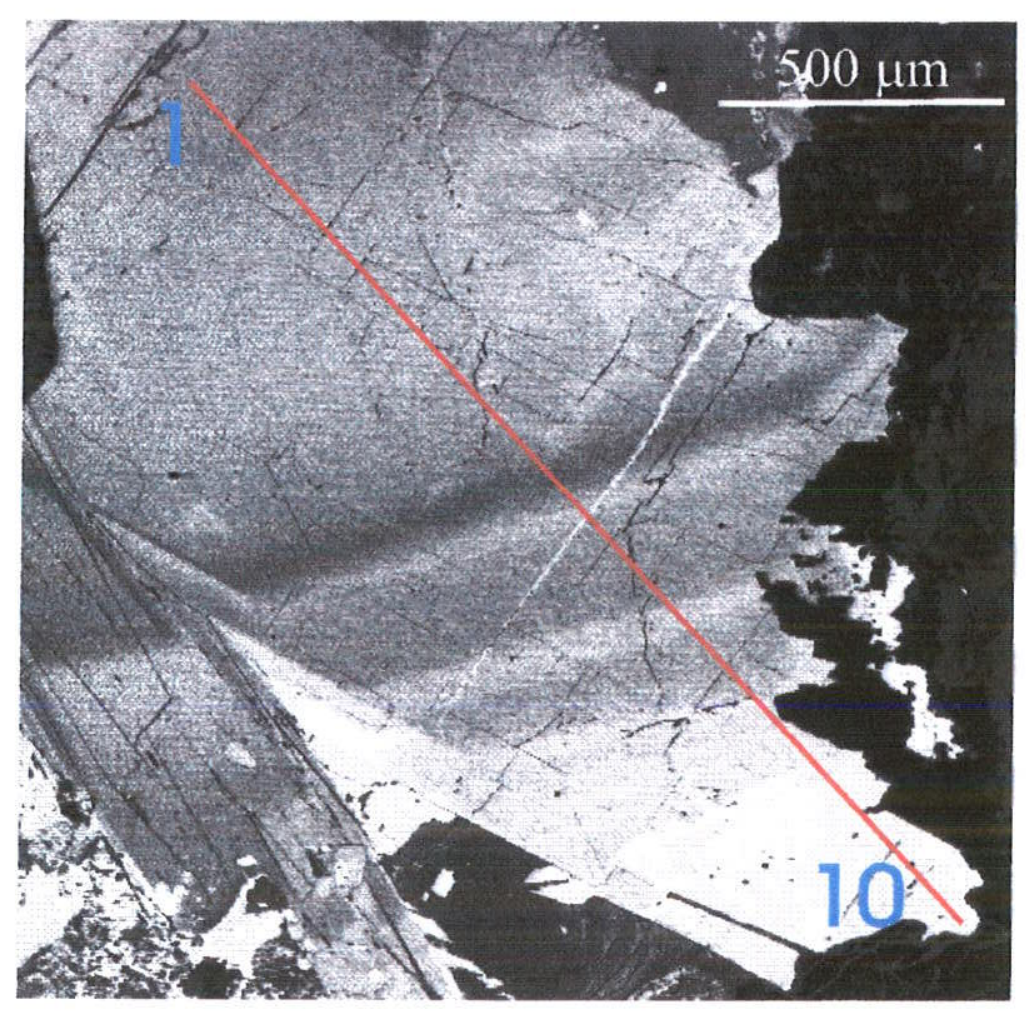

D

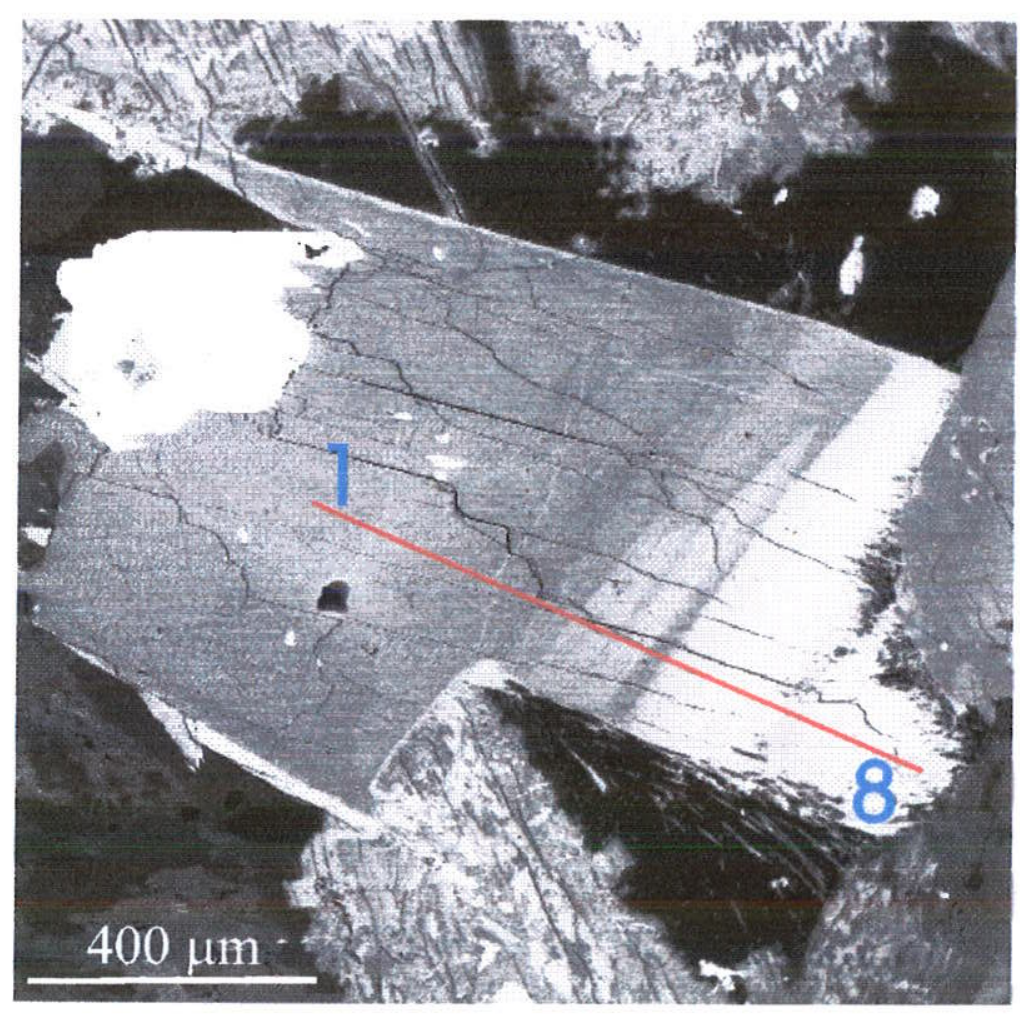

Figura V.19. Continuação. 


\section{V.1.4 Biotita}

A biotita é um mineral primário relevante apenas em algumas variedades das rochas dioriticas e hibridas. Na fácies melasienítica é primária, pouco abundante e de cristalização relativamente tardia. Nas variedades sieniticas é, principalmente, um mineral pós-magmático e na fácies granítica está tipicamente ausente.

\section{V.1.4.I Texturas}

Nas rochas dioríticas e enclaves monzoniticos, a biotita apresenta tonalidades castanho-claras e marron-avermelhadas e é subidiomónfica a xenomórfica, ocorrendo em cristais isolados, por vezes bem alongados, ou em agregados máficos com clinopiroxênio, anfibólio e minerais opacos (Fïgura V.24A e V.24B).

Nos melasienitos a biotita é xenomórfica e aparece intersticialmente, ocupando espaços entre olivina, clinopiroxênio e minerais opacos, e também formando mantos, ora sobre a olivina, ora sobre os minerais opacos. As tonalidades de pleocróismo variam entre o marron claro e o castanho avermelhado.

Nas fácies sieniticas verde e rosa é tipicamente pós-magmática, aparecendo como agregados de cristais idiomórficos com tonalidades de pleocrósmo castanho-avermelhadas, associados aos agregados tardios intersticiais, junto com filossilicatos finos não identificados, anfibólio actinolítico prismático a acicular e magnetita.

\section{V.1.4.2 Quimismo}

Algumas análises quimicas para caracterização geral foram efetuadas para a biotita das rochas melasienitica, dioríticas e híbridas associadas (Tabela V.4). 
A biotita do melasienito é homogênea composicionalmente e corresponde a uma annita, com mg\# por volta de 0,35 . Nas rochas dioriticas e hibridas, a biotita é também uma annita na maioria das amostras analisadas, com mg\# entre 0,33 e 0,48; apenas uma amostra (Co-50B) apresenta conteúdo mais significativo da molécula flogopita, com mg\# próximo a 0,55 . A proporção de $\mathrm{Al}^{\mathrm{IV}}$ é relativamente baixa, inferior a 2,25 c.p.f.u. em todos os casos, e inferior a 2,15 c.p.f.u. na biotita do melasienito (Fïgura V.20). A soma dos cátions ocupantes do sítio cristalográfico X encontra-se entre 1,80 e 2,10 c.p.f.u., representando uma baixa variação nos teores de $\mathrm{Ba}, \mathrm{K}, \mathrm{Na}$ e $\mathrm{Ca}$ e, com isso, fornecendo uma correlação de qualidade muito baixa em relação à Si (Figura V.2I).

De forma geral a biotita presente nas rochas dioriticas e hibridas apresenta teores médios mais elevados de $\mathrm{TiO}_{2}$ (até $6,78 \%$ em peso) e $\mathrm{BaO}$ (até 1,56\% em peso) e menores de $\mathrm{MgO}+\mathrm{FeO}+\mathrm{MnO}$, quando comparada com a da fácies melasienítica. Em ambas as rochas a ocupação dos sítio octaédrico Y situa-se, em geral, entre 6,2 e 6,5 c.p.f.u. As principais correlações catiônicas evidenciadas pelos dados analíticos neste sítio correspondem ao leve incremento de $\mathrm{Al}^{\mathrm{V}}$ com os cátions bivalentes, observando-se de forma geral que a biotita dos melasienitos apresenta conteúdos em média pouco mais elevados de $\mathrm{Al}^{\mathrm{VI}} \mathrm{e}(\mathrm{Fe}+\mathrm{Mg}+\mathrm{Mn})^{Y}$ (Figura V.23) e, principalmente entre $\mathrm{Ti}^{\mathrm{Y}}$ e $(\mathrm{Fe}+\mathrm{Mg}+\mathrm{Mn})^{\mathrm{Y}}$ (Figura V.22). A boa correlação negativa observada neste último diagrama, sugere que as variações composicionais presentes neste mineral podem ser satisfatoriamente descritas por uma reação de substituição do tịpo:

$$
2(\mathrm{Fe}+\mathrm{Mg}+\mathrm{Mn})^{\mathrm{X}}=[]^{\mathrm{Y}}+\mathrm{Ti}^{\mathrm{Y}}
$$

em que [] representa uma vacância no sítio $Y$.

Reações mais específicas, envolvendo também outros elementos são mais dificeis de serem avaliadas, uma vez que não se observam variações composicionais significativas e não estão disponíveis dados analiticos para $\mathrm{Fe}_{2} \mathrm{O}_{3}$. 


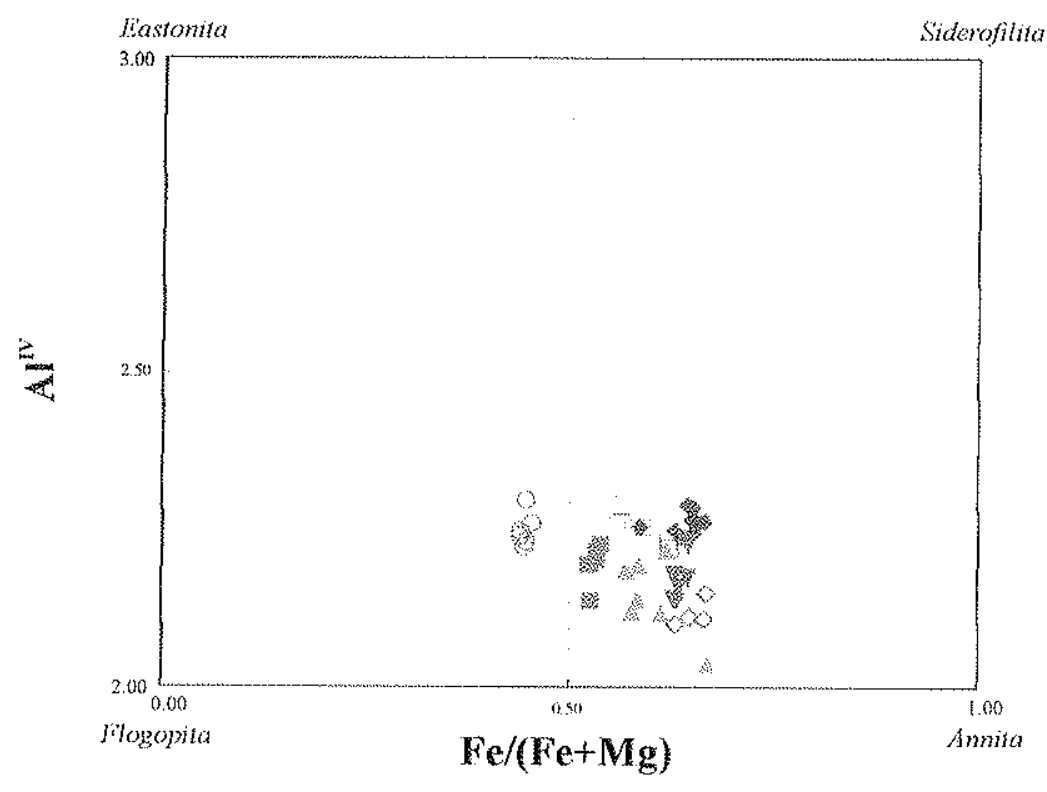

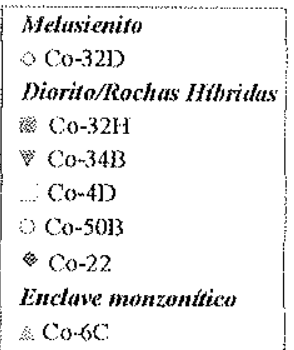

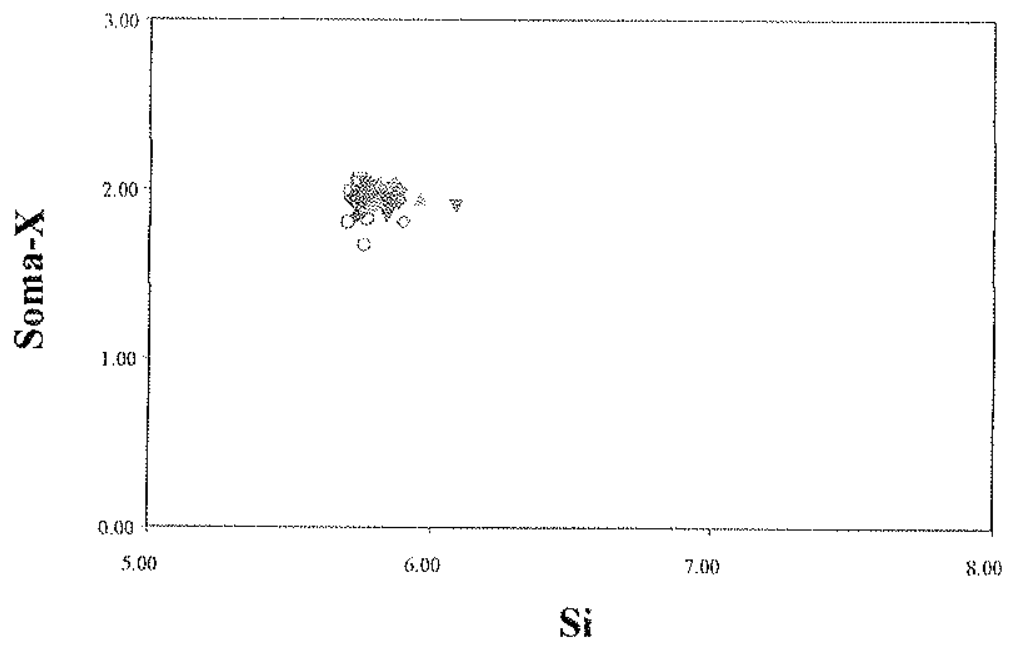

Figura V.21. Diagrama mostrando a variação entre as proporções cationnicas (Si $x$ Soma-X) da biotita das fácies melasienitica, dioritica/rochas hibridas e enclaves monzoniticos. 


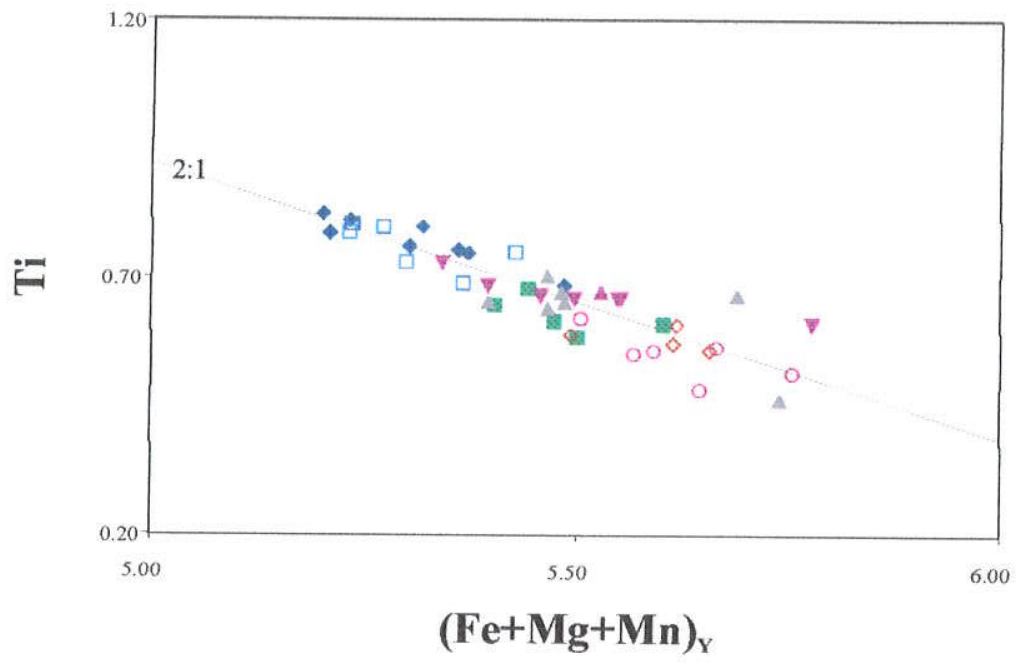

Figura V.22. Diagrama mostrando correlação entre as proporções catiônicas $\left[(\mathrm{Fe}+\mathrm{Mg}+\mathrm{Mn})_{y} \times \mathrm{Ti}\right]$ para biotita das fácies melasienítica, diorítica/rochas hibridas $e$ enclaves monzoniticos.

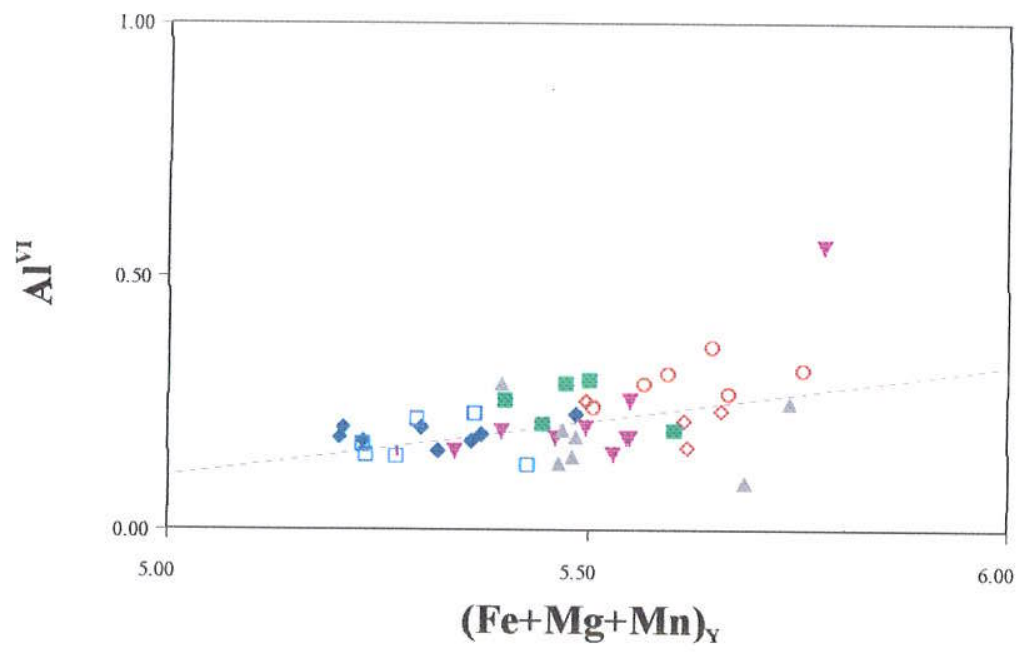

Melasienito

$\diamond \mathrm{Co}-32 \mathrm{D}$

Diorito/Rochas Hibridas

침 $\mathrm{Co}-32 \mathrm{H}$

$\nabla \mathrm{Co}-34 \mathrm{~B}$

$\square \mathrm{Co}-4 \mathrm{D}$

$\mathrm{Co}-50 \mathrm{~B}$

Co-22

Enclave monzonútico

$\triangle \mathrm{Co}-6 \mathrm{C}$

Figura V.23. Diagrama mostrando a correlação entre as proporções catiônicas $\left[(\mathrm{Fe}+\mathrm{Mg}+\mathrm{Mn})_{Y} \times \mathrm{Al}^{\mathrm{VI}}\right]$ para biotita das fácies melasienítica, diorítica/rochas híbridas e enclaves monzoniticos. 


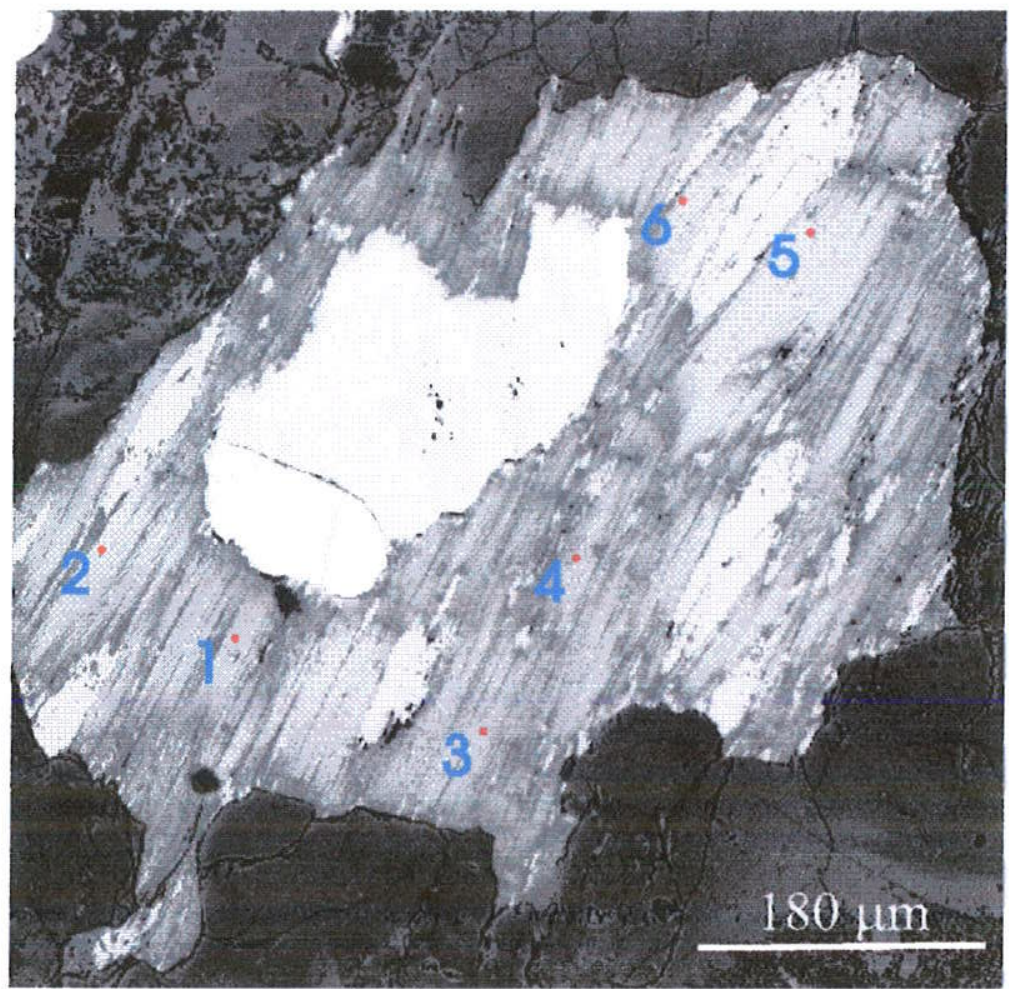

$\boldsymbol{B}$

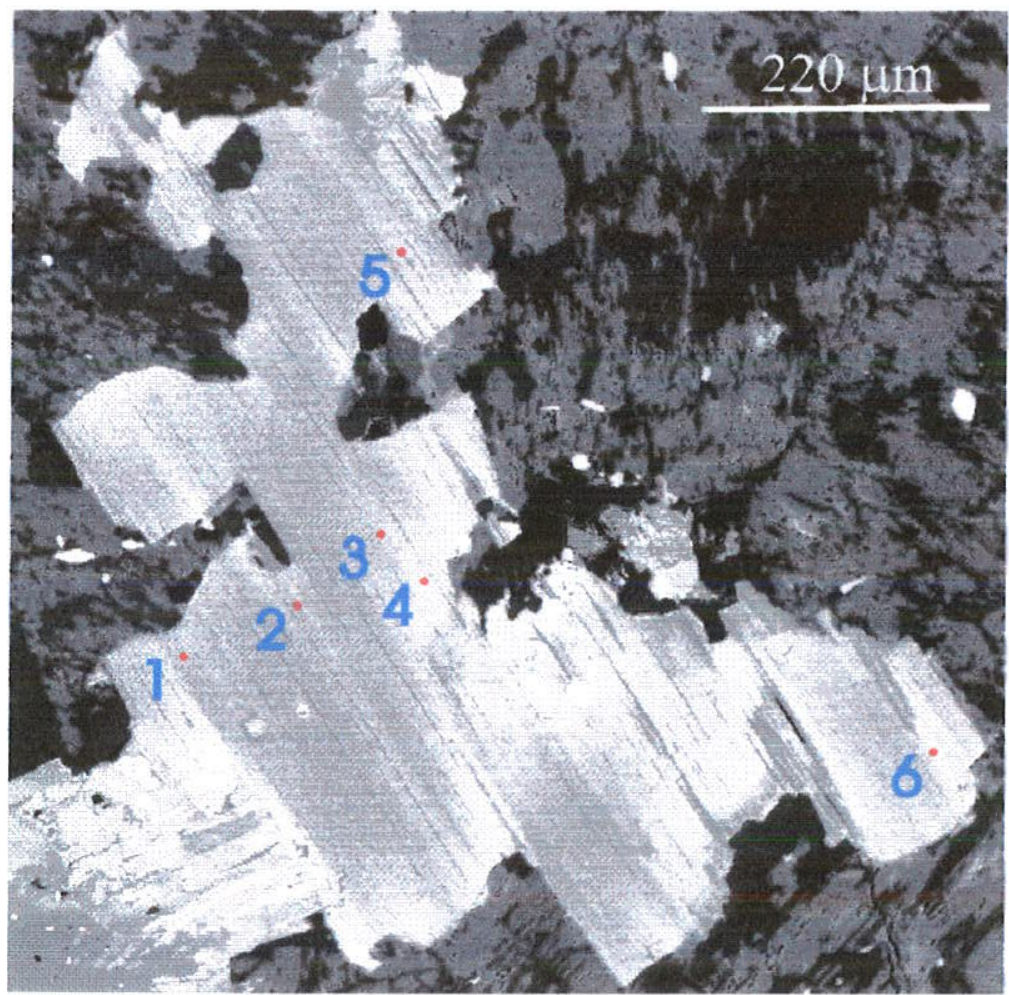

Figura V.24. Imagens de elétrons retro-espalhados, em modo composicional, para cristais de biotita com localização dos pontos analíticos WDS. A: fácies diorítica, cristal claro irregular corresponde a um mineral opaco (ilmenita ou magnetita), cristais claros alongados correspondem à prenhita. B: cristal em fácies híbrida (enclave monzonítico). 


\section{V.2 Minerais Félsicos}

\section{V.2.1 Plagioclasio}

\section{V.2.1.1 Texturas}

O plagioclásio é a fase mineral félsica predominante nos dioritos; nas rochas hibridas e no enclave monzonítico é acompanhado de quantidades significativas de feldspato alcalino. Apresentase como cristais tabulares, subidiomórficos a idiomórficos, com zonamento composicional concêntrico normal a oscilatório. A saussuritização é variável nas amostras, sendo moderada nos dioritos. Inclusões de minerais máfícos e opacos ocorrem, mas não são muito freqüentes (Frigura V.25B).

\section{V.2.1.2 Quimismo}

Os cristais de plagioclásio dos enclaves monzoniticos nâo foram analisados quimicamente, porém suas características óticas permitem definir sua composição no intervalo do oligoclásio $\left(\mathrm{An}_{25-15}\right)$.

Nos dioritos o plagioclásio apresenta zonamentos químicos mediamente variáveis. $O$ perfil obtido para um grão da amostra Co-50B (Fïgura V.25B), indica uma composição de andesina cálcica para o núcleo $\left(\mathrm{An}_{45}\right)$ e oligoclásio para as zonas intermediárias e bordas $\left(\mathrm{An}_{25-15}\right.$, respectivamente) (Figura V.25A), numa passagem descontinua, indicando maior oscilação composicional no núcleo e na borda do grão, mantendo-se constantes as zonas intermediárias. Os teores de Or mantêm-se constantes até o limite entre o núcleo e zonas intermediárias do cristal, onde aumentam, permanecendo assim até próximo à zona de borda, onde voltam a diminuir para teores próximos aos da região do núcleo. (Figura V.25C; Tabela V.5). A variação abrupta nos teores de $\mathrm{Ab}$ e An $(\sim 50 \% \rightarrow 75 \%$ e $\sim 50 \% \rightarrow 25 \%$, respectivamente) observados no gráfico da Figura V.26C está provavelmente relacionada com a evidente variação composicional do cristal mostrada pela Figura V.25B. 


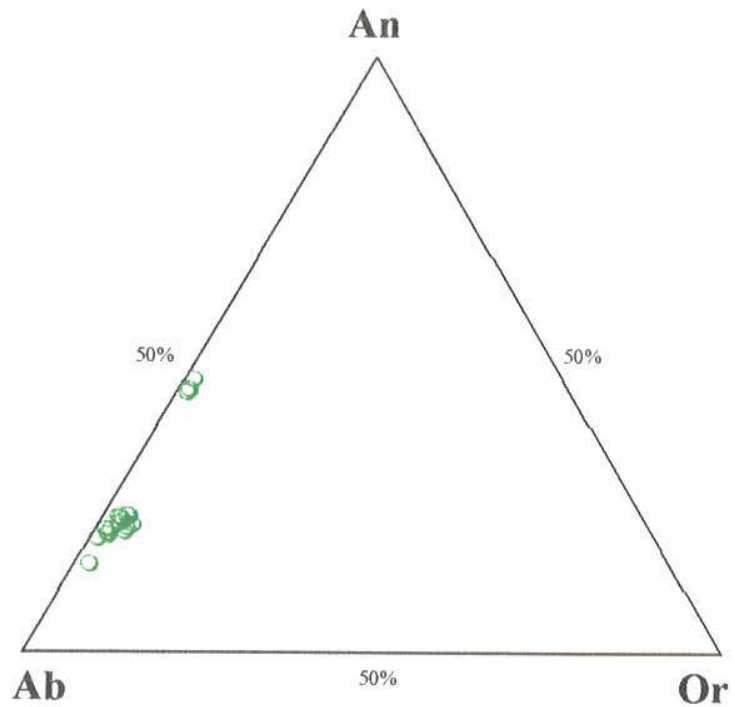

B

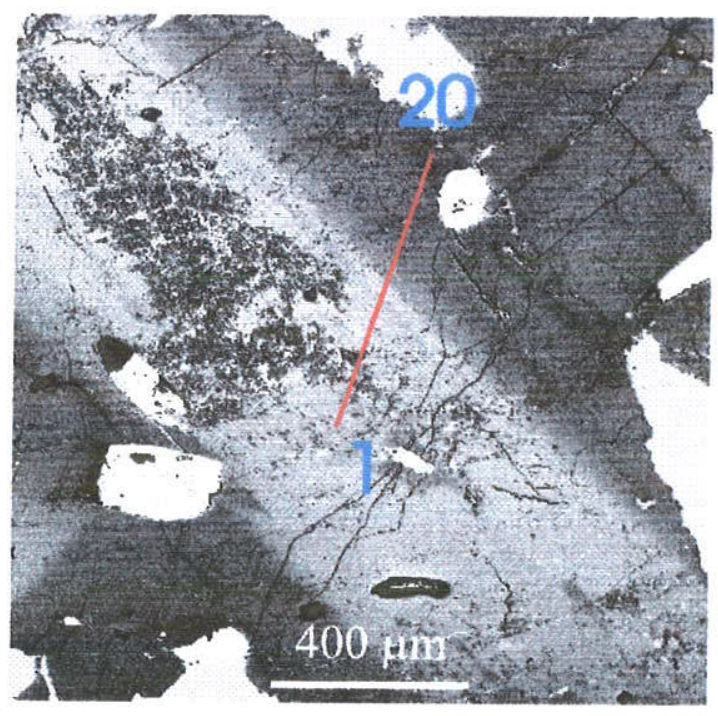

C

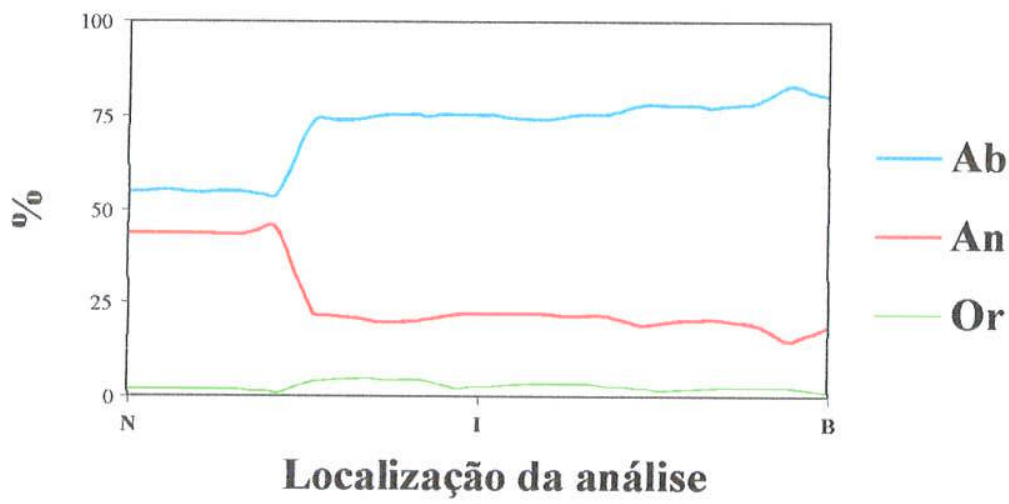

Figura V.25. (A): Diagrama ternário An-Ab-Or ilustrando a variação composicional, em proporções moleculares, de cristal de plagioclásio da fácies diorítica (imagem exibida em B); (B): imagem de elétrons retro-espalhados em modo composicional do cristal de plagioclásio, mostrando perfil analítico WDS efetuado e o número de análises, observar zonamento composicional núcleo-borda normal, simples; (C): perfil composicional ilustrando a variação das moléculas de An, Ab e Or. 


\section{V.2.2 Feldspato alcalino}

$O$ feldspato alcalino é a fase félsica mais abundante nas rochas sieníticas e graniticas estudadas. Na fácies melasienítica aparece em quantidades mais subordinadas, constituindo a principal fase inter-cúmulus.

\section{V.2.2.1 Texhuras}

O feldspato alcalino dos álcali-feldspato sienitos e granitos corresponde a uma mesopertita. As lamelas exsolvidas de albita ocorre com morfologias diversas, no entanto, a albita em forma de veios ou filmes medianamente regulares, de espessuras variáveis, são as mais comuns. Albita límpida tardi- a pós-magmática ocorre também intersticial aos cristais de feldspato alcalino, por vezes em cristais bem formados.

Nas rochas sieníticas mais félsicas (sienitos róseos) e, em especial nos granitos, são comuns os intercrescimentos micro-granofiricos entre feldspato alcalino e quartzo cuneiforme que, em geral ocorrem intersticiais ou como sobrecrescimentos com contatos bem definidos sobre núcleos cristalinos de feldspatos mesopertíticos idiomórficos.

\section{V.2.2.2 Quimismo}

Análises quimicas de feldspato alcalino foram obtidas para as rochas sieníticas e graníticas. Os dados apresentados correspondem a estimativas de sua composição global, obtidas a partir da integração de análises pontuais efetuadas para as fases potássica e sódica (ver Capítulo III, Ítem III.2.2).

$\mathrm{Na}$ fácies melasienítica, as composições do feldspato alcalino situam-se no intervalo entre $\mathrm{Or}_{31-41}$ (Figtura V.26), contendo em média maior quantidade da molécula de Or nas bordas. Os conteúdos da molécula de An (entre 4,9 e 7,1\%) e de $\mathrm{BaO}$ (entre 0,4 e 0,5\% em peso) do feldspato 
alcalino desta fácies são relativamente altos e correspondem aos maiores valores medidos para as rochas estudadas; por outro lado, os valores de $\mathrm{Fe}_{2} \mathrm{O}_{3}$ são, em média, inferiores (Tabela V.6).

Nas fácies sieníticas de granulação grossa, as composições integradas para o feldspato alcalino são mais variáveis (Figura V.26). No caso da fácies verde, as composições situam-se no intervalo entre $\mathrm{Or}_{25-52}$, com um conteúdo na molécula de An que alcança 4,5\%. Os teores de $\mathrm{BaO}$ são baixos, por vezes inferiores ao limite de deteç̧ão. Os valores de $\mathrm{Fe}_{2} \mathrm{O}_{3}$, por outro lado, são significativos para a maioria das amostras, alcançando $1,2 \%$ em peso na amostra $\mathrm{Co}-32 \mathrm{C}$.

Composições integradas semelhantes, entre $\mathrm{Or}_{29.57}$, foram obtidas para as variedades sieníticas róseas, mas os teores na molécula de An são em média inferiores, alcançando o teto de $3,3 \%$ molecular na amostra Co-51. Uma única amostra sienítica verde de granulação média resultou em composições mais homogêneas, com teores em média mais elevados da molécula de Or (entre 38 e $44 \%$ molecular) e valores inferiores a 1,6\% molecular de An.

$\mathrm{Na}$ fácies granítica (amostra Co-2A), o feldspato alcalino revela-se algo mais homogêneo, as composições integradas situando-se no intervalo $\mathrm{Or}_{48-52}$. Os valores de An são muito baixos $(<0,1 \%$ molecular), com os teores $\mathrm{Ca}$ abaixo do limite de detecção.

As composições obtidas indicam de forma bastante clara que os teores em $\mathrm{CaO}$ e $\mathrm{BaO}$ diminuem dos melasienitos para os sienitos e destes para os granitos. Aparentemente, neste mesmo sentido existe algum aumento na quantidade da molécula de Or do feldspato alcalino. Por outro lado, deve ser destacado que os intervalos composicionais integrados mais amplos obtidos nas rochas sieníticas, em particular nas variedades de granulação mais grossa, devem estar sujeitos a erros maiores, devido a maior dificuldade no processo de integração, dada a maior irregularidade das lamelas de albita na mesopertita.

No diagrama da Figura V.26, são representadas curvas de solvus para temperaturas de $800^{\circ}$, $900^{\circ}$ e $1000^{\circ} \mathrm{C}$, avaliadas para uma pressão total de $1 \mathrm{Kbar}$ em condições de saturação em água, de acordo com o modelo de Elkins \& Grove (1990) (ver também Wen \& Nekvasil, 1994). Apesar 
destas condições serem algo superestimadas em relação às esperadas para o ambiente de cristalização destas rochas, as curvas são siginiffcativas e poden ser utilizadas como referência. Este diagrama demonstra bem a diminuição das temperaturas de cristalização dos feldspatos alcalinos em direção às fácies petrográficas mais félsicas; o melasienito sugerindo temperaturas de cristalização do feldspato alcalino entre $900^{\circ}$ e $1000^{\circ} \mathrm{C}$, os sienitos mais máficos diminuindo para o intervalo de $800^{\circ}$ a $900^{\circ} \mathrm{C}$ e, finalmente, os sienitos mais diferenciados es granitos $\left(<800^{\circ} \mathrm{C}\right)$. 


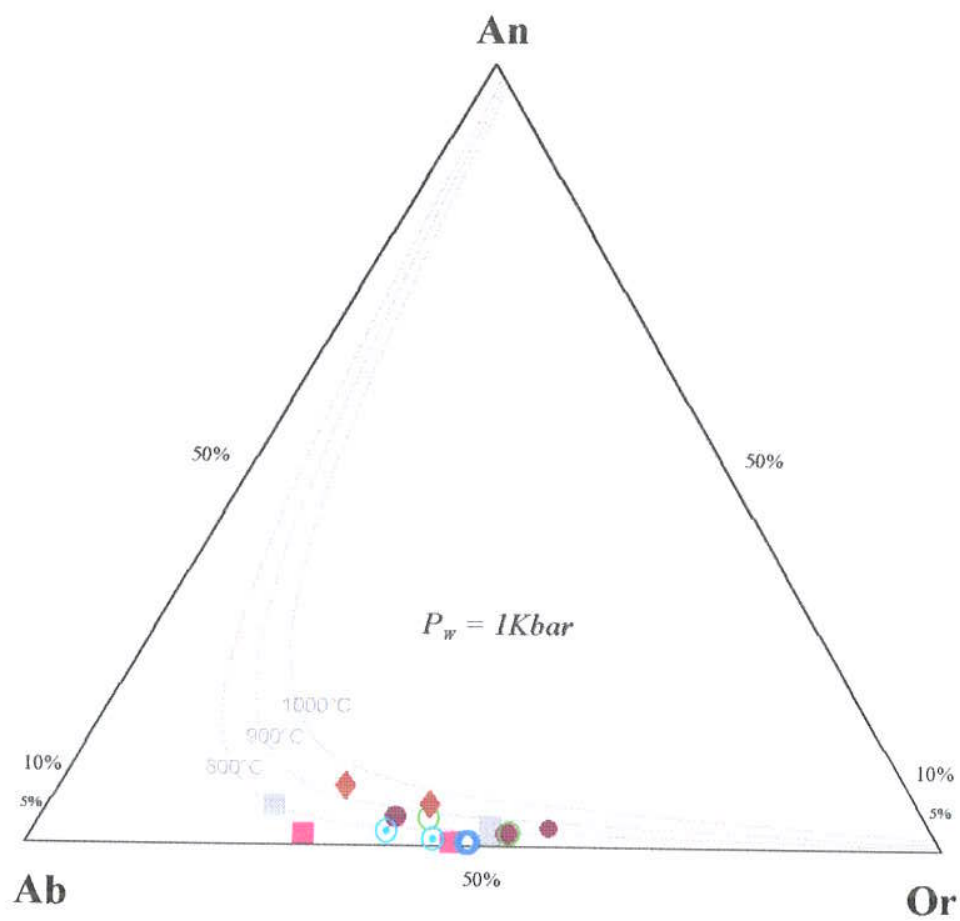

Granito

- $\mathrm{Co}-2 \mathrm{~A}$

Sienito róseo grosso

- $\mathrm{Co}-32 \mathrm{~A}$

- Co-51

Sienito verde grosso

Co-32C

Co-1

Sienito verde médio

(-) $\mathrm{Co}-5$

Melasienito

- Co-32D

Figura V.26. Diagrama ternário An-Ab-Or (em proporções moleculares) ilustrando as estimativas das composições originais obtidas para feldspato alcalino das rochas sieniticas e graníticas. As curvas cotéticas para 800,900 e $1000^{\circ} \mathrm{C}\left(P_{W}=1 \mathrm{Kbar}\right)$ encontram-se inseridas no diagrama.

(Modelo Elkins \& Grove, 1990; Calculado com o programa SOLVCALC de Wen \& Nekvasil, 1994).

$\mathrm{P}_{\mathrm{w}}$ : pressão e saturação em $\mathrm{H}_{2} \mathrm{O}$. 
Tabela V.1. Análises quimicas WDSj e fórmula esirutural de olvina das rochas do Maciço Conupá.

\begin{tabular}{|c|c|c|c|c|c|c|c|c|c|c|c|c|}
\hline \multirow{3}{*}{$\begin{array}{c}\text { Fácies } \\
\text { Amostra } \\
\text { Análise }\end{array}$} & \multicolumn{6}{|c|}{ Sienito Verde Grosso } & \multicolumn{6}{|c|}{ Melasienito } \\
\hline & \multicolumn{6}{|c|}{$32 \mathrm{C}$} & \multicolumn{6}{|c|}{$32 \mathrm{D}$} \\
\hline & $p t 1$ & $p t 2$ & $p t 3$ & $p t+$ & $p t 5$ & pt6 & ptl/grãol & ptz/grãol & pt3/grãol & pt4/grãol & pt5/grãol & pto/grão \\
\hline Localização & $N$ & $N-I$ & $I$ & $B$ & $B$ & $I-B$ & $B$ & $B$ & $I-B$ & $I$ & I & $N$ \\
\hline $\mathrm{SiO}_{2}$ & 29.88 & 30.68 & 30.47 & 30.25 & 29.94 & 30.40 & 30.87 & 31.32 & 30.71 & 31.63 & 31.57 & 31.65 \\
\hline $\mathrm{TiO}_{2}$ & 0.07 & 0.12 & <L. D. & 0.09 & <L. D. & 0.06 & $<$ L. D. & 0.10 & 0.08 & 0.10 & $<$ L. D. & 0.06 \\
\hline $\mathrm{FeO}$ & 62.99 & 62.86 & 62.90 & 63.42 & 62.99 & 63.29 & 58.44 & 58.04 & 57.69 & 57.43 & 57.34 & 58.08 \\
\hline Mno & 2.39 & 2.41 & 2.43 & 2.59 & 2.43 & 2.39 & 2.03 & 1.97 & 1.95 & 1.92 & 2.00 & 2.03 \\
\hline MgO & 3.86 & 3.91 & 3.70 & 3.00 & 3.74 & 3.84 & 8.78 & 8.19 & 8.74 & 8.82 & 8.75 & 8.98 \\
\hline $\mathrm{CaO}$ & 0.30 & 0.24 & 0.22 & 0.22 & 0.17 & $<$ L. D. & 0.23 & 0.15 & 0.22 & 0.23 & 0.23 & 0.19 \\
\hline Total & 99.49 & 100.21 & 99.70 & 99.57 & 99.27 & 99.98 & 100.34 & 99.77 & 99.38 & 100.13 & 99.90 & 100.99 \\
\hline \multicolumn{13}{|c|}{ rmula estrutural com base em 4 oxigênios } \\
\hline Si & 0.990 & 1.004 & 1.004 & 1.003 & 0.994 & 1.000 & 0.982 & 0.999 & 0.985 & 1.000 & 1.001 & 0.995 \\
\hline $\operatorname{Som} a-T$ & 0.990 & 1.004 & 1.004 & 1.003 & 0.994 & 1.000 & 0.982 & 0.999 & 0.985 & 1.000 & 1.001 & 0.995 \\
\hline $\mathrm{Ti}$ & 0.002 & 0.003 & 0.000 & 0.002 & 0.000 & 0.002 & 0.000 & 0.002 & 0.002 & 0.002 & 0.000 & 0.001 \\
\hline $\mathrm{Fe}^{2+}$ & 1.746 & 1.720 & 1.734 & 1.759 & 1.748 & 1.741 & 1.555 & 1.548 & 1.547 & 1.519 & 1.521 & 1.526 \\
\hline $\mathrm{Mn}$ & 0.067 & 0.067 & 0.068 & 0.073 & 0.068 & 0.067 & 0.055 & 0.053 & 0.053 & 0.052 & 0.054 & 0.054 \\
\hline Mg & 0.191 & 0.191 & 0.182 & 0.148 & 0.185 & 0.188 & 0.416 & 0.389 & 0.418 & 0.416 & 0.414 & 0.420 \\
\hline $\mathrm{Ca}$ & 0.011 & 0.008 & 0.008 & 0.008 & 0.006 & 0.000 & 0.008 & 0.005 & 0.007 & 0.008 & 0.008 & 0.006 \\
\hline Soma-M2 & 2.017 & $1: 989$ & 1.992 & 1.990 & 2.007 & 1.998 & 2.035 & 1.997 & 2.027 & 1.997 & 1.997 & 2.007 \\
\hline Cátions & 3.009 & 2.993 & 2.996 & 2.994 & 3.003 & 2.999 & 3.019 & 2.997 & 3.012 & 2.997 & 2.999 & 3.003 \\
\hline$m g \#$ & 0.100 & 0.100 & 0.090 & 0.080 & 0.100 & 0.100 & 0.210 & 0.200 & 0.210 & 0.210 & 0.210 & 0.220 \\
\hline$m n \#$ & 0.037 & 0.037 & 0.038 & 0.040 & 0.037 & 0.037 & 0.034 & 0.033 & 0.033 & 0.033 & 0.034 & 0.034 \\
\hline
\end{tabular}

Obs: 1- N, núcleo; I, região intermediária; $\mathrm{B}$, borda; pt, ponto analisado.

2-<L. D. : abaixo do limite de detecção

3- $\mathrm{mg} \#=\mathrm{Mg} /\left(\mathrm{Mg}+\mathrm{Fe}^{2+}\right)$

4- $\mathrm{mn} \#=\mathrm{Mn} /\left(\mathrm{Mn}+\mathrm{Fe}^{2+}\right)$. 
Tabela V.1. Continuação.

\section{Melasienito}

$$
\text { 32D }
$$

$\begin{array}{cccccc}\text { Análise } & t \text { /7grãol } & \text { t8/grãol } & \text { t9/grãol } & \text { tlo/grão } & \text { tlligrãol } \\ & N-I & N-I & I & I-B & B \\ \mathrm{SiO}_{2} & 31.62 & 31.29 & 31.85 & 30.92 & 31.47 \\ \mathrm{TiO}_{2} & 0.05 & 0.09 & 0.08 & <\mathrm{L} . \mathrm{D} . & <\mathrm{L} . \mathrm{D} . \\ \mathbf{F e O} & 57.55 & 57.35 & 57.26 & 57.92 & 57.69 \\ \mathbf{M n O} & 2.02 & 1.96 & 2.02 & 1.92 & 1.93 \\ \mathbf{M g O} & 9.19 & 8.97 & 9.26 & 9.53 & 9.27 \\ \text { CaO } & 0.23 & 0.23 & 0.26 & 0.18 & 0.15 \\ \text { Total } & \mathbf{1 0 0 . 6 7} & \mathbf{9 9 . 8 9} & \mathbf{1 0 0 . 7 3} & \mathbf{1 0 0 . 4 7} & \mathbf{1 0 0 . 5 1}\end{array}$

Fórmula estrutural com base em 4 oxigênios

$\begin{array}{ccccccccc}\text { Si } & 0.995 & 0.994 & 0.999 & 0.979 & 0.993 & 0.993 & 0.992 & 0.991 \\ \text { Soma-T } & 0.995 & 0.994 & 0.999 & 0.979 & 0.993 & 0.993 & 0.992 & 0.991 \\ \mathbf{T i} & 0.001 & 0.002 & 0.002 & 0.000 & 0.000 & 0.002 & 0.001 & 0.001 \\ \mathbf{F e}^{2+} & 1.515 & 1.523 & 1.502 & 1.533 & 1.522 & 1.504 & 1.506 & 1.527 \\ \mathbf{M n} & 0.054 & 0.053 & 0.054 & 0.051 & 0.052 & 0.055 & 0.056 & 0.051 \\ \mathbf{M g} & 0.431 & 0.425 & 0.433 & 0.449 & 0.436 & 0.441 & 0.445 & 0.431 \\ \mathbf{C a} & 0.008 & 0.008 & 0.009 & 0.006 & 0.005 & 0.007 & 0.005 & 0.005 \\ \text { Soma-M2 } & \mathbf{2 . 0 0 9} & 2.011 & 2.000 & 2.039 & 2.015 & 2.009 & 2.013 & 2.015 \\ \text { Cátions } & \mathbf{3 . 0 0 4} & \mathbf{3 . 0 0 5} & 2.999 & \mathbf{3 . 0 1 9} & 3.008 & \mathbf{3 . 0 0 4} & \mathbf{3 . 0 0 6} & 3.009 \\ \boldsymbol{m g} \# & 0.220 & 0.220 & 0.220 & 0.230 & 0.220 & 0.230 & 0.230 & 0.220 \\ m n \# & 0.034 & 0.034 & 0.035 & 0.032 & 0.033 & 0.035 & 0.036 & 0.032\end{array}$

Obs: $1-\mathrm{N}$, núcleo; 1 , região intermediária; $\mathrm{B}$, borda; $\mathrm{pt}$, ponto analisado 2-<L. D. : abaixo do limite de detecção

3- $\mathrm{mg} \#=\mathrm{Mg} /\left(\mathrm{Mg}+\mathrm{Fe}^{2+}\right)$

4- $\mathrm{mn} \#=\mathrm{Mn} /\left(\mathrm{Mn}+\mathrm{Fe}^{2+}\right)$.

\section{Melasienito}

$$
\text { 32D }
$$

ptl/grão2 t2/grão2 t3/grão2

$\begin{array}{ccc}N & B & B \\ 31.26 & 31.55 & 31.35 \\ 0.10 & 0.06 & 0.06 \\ 56.65 & 57.27 & 57.78 \\ 2.06 & 2.09 & 1.90 \\ 9.32 & 9.48 & 9.14 \\ 0.20 & 0.16 & 0.14 \\ \mathbf{9 9 . 5 9} & \mathbf{1 0 0 . 6 1} & \mathbf{1 0 0 . 3 7}\end{array}$

$\begin{array}{lll}99.59 & 100.61 \quad 100.37\end{array}$ 
Tabela V.2. Análises químicas (WDS) e fórmulas estruturais de clinopiroxênio das rochas do Maciço Corupá.

\begin{tabular}{|c|c|c|c|c|c|c|c|c|c|c|c|c|c|c|c|}
\hline $\begin{array}{l}\text { Fácies } \\
\text { Amostra }\end{array}$ & & & & $\begin{array}{c}\text { Diorito } \\
50 \mathrm{~B}\end{array}$ & & & & & & & $\begin{array}{r}\text { Rocha } \\
3\end{array}$ & ibrida & & & \\
\hline $\begin{array}{l}\text { Análise } \\
\text { ocalização }\end{array}$ & pt 1 & pt 2 & pt 3 & pt 4 & pt 5 & pt 7 & pt 8 & pt 1 & $\mathrm{pt} 2$ & pt 3 & pt 4 & pt 5 & pt 6 & pt7 & pt 8 \\
\hline $\mathrm{SiO}_{2}$ & 51,92 & 52,05 & 51,72 & 50,42 & 50,72 & 50,89 & 49,89 & 50,98 & 52,32 & 49,97 & 51,19 & 50,59 & 51,16 & 51,42 & 51,21 \\
\hline $\mathrm{TiO}_{2}$ & 0,40 & 0,38 & 0,46 & 0,84 & 0,91 & 0,79 & 1,03 & 0,89 & 0,12 & 1,12 & 0,88 & 0,87 & 0,89 & 0,84 & 0,98 \\
\hline $\mathrm{Al}_{2} \mathrm{O}_{3}$ & 1,00 & 1,14 & 1,20 & 2,15 & 3,01 & 2,25 & 3,38 & 1,39 & 0,35 & 1,67 & 1,33 & 1,39 & 1,28 & 1,54 & 1,65 \\
\hline $\mathrm{Fe}_{2} \mathrm{O}_{3}$ & 2,96 & 1,80 & 2,78 & 3,98 & 3,32 & 2,90 & 3,96 & 1,45 & 0,00 & 1,60 & 0,39 & 1,16 & 0,74 & 0,91 & 0,31 \\
\hline $\mathrm{FeO}$ & 7,36 & 7,42 & 7,12 & 5,11 & 6,02 & 5,57 & 5,37 & 12,84 & 15,27 & 13,66 & 13,55 & 12,92 & 13,03 & 11,61 & 13,43 \\
\hline $\mathrm{MnO}$ & 0,37 & 0,36 & 0,42 & 0,33 & 0,27 & 0,28 & 0,24 & 0,68 & 0,67 & 0,71 & 0,64 & 0,59 & 0,66 & 0,56 & 0,71 \\
\hline $\mathrm{MgO}$ & 14,47 & 14,13 & 14,46 & 14,06 & 14,27 & 14,01 & 14,06 & 11,57 & 10,32 & 10,91 & 11,46 & 11,28 & 11,44 & 12,66 & 11,73 \\
\hline $\mathrm{CaO}$ & 21,03 & 21,69 & 21,17 & 22,32 & 20,67 & 22,53 & 20,89 & 20,08 & 20,69 & 19,58 & 19,96 & 20,20 & 20,43 & 20,20 & 19,61 \\
\hline $\mathrm{Na}_{2} \mathrm{O}$ & 0,42 & 0,39 & 0,39 & 0,41 & 0,64 & 0,39 & 0,65 & 0,41 & 0,33 & 0,40 & 0,39 & 0,37 & 0,37 & 0,35 & 0,42 \\
\hline $\mathrm{K}_{2} \mathrm{O}$ & <L. D. & <L. D. & $<\mathrm{L} . \mathrm{D}$ & <L. D. & 0,09 & <L. D. & 0,05 & <L. D. & $<\mathrm{L} . \mathrm{D}$. & $<$ L. D. & < L. D. & $<\mathrm{L}$. D. & <L. D. & <E. D. & < L. D. \\
\hline Total & 99,94 & 99,36 & 99,73 & 99,63 & 99,92 & 99,62 & 99,51 & 100,29 & 100,07 & 99,63 & 99,79 & 99,39 & 100,00 & 100,10 & 100,05 \\
\hline órmula e & rutural & n base & 6 oxig & s e 40 & & & & & & & & & & & \\
\hline $\mathrm{Si}$ & 1,940 & 1,953 & $1,935^{\circ}$ & 1,888 & 1,887 & 1,902 & 1,865 & 1,938 & 2,006 & 1,921 & 1,954 & 1,941 & 1,949 & 1,941 & 1,946 \\
\hline $\mathrm{Al}_{\mathrm{rV}}$ & 0,044 & 0,047 & 0,053 & 0,095 & 0,113 & 0,098 & 0,135 & 0,062 & 0,000 & 0,076 & 0,046 & 0,059 & 0,051 & 0,059 & 0,054 \\
\hline $\mathrm{Fe}^{3+}$ & 0,016 & 0,000 & 0,012 & 0,017 & 0,000 & 0,000 & 0,000 & 0,000 & 0,000 & 0,003 & 0,000 & 0,000 & 0,000 & 0,000 & 0,000 \\
\hline$S O M A-T$ & 2,000 & 2,000 & 2,000 & 2,000 & 2,000 & 2,000 & 2,000 & 2,000 & 2,006 & 2,000 & 2,000 & 2,000 & 2,000 & 2,000 & 2,000 \\
\hline $\mathrm{Al}_{\mathrm{VI}}$ & 0,000 & 0,003 & 0,000 & 0,000 & 0,019 & 0,001 & 0,014 & 0,000 & 0,016 & 0,000 & 0,014 & 0,004 & 0,006 & 0,010 & 0,020 \\
\hline $\mathrm{Ti}$ & 0,011 & 0,011 & 0,013 & 0,024 & 0,026 & 0,022 & 0,029 & 0,025 & 0,003 & 0,032 & 0,025 & 0,025 & 0,026 & 0,024 & 0,028 \\
\hline $\mathrm{Fe}^{3 \div}$ & 0,067 & 0,051 & 0,067 & 0,094 & 0,093 & 0,081 & 0,111 & 0,041 & 0,000 & 0,044 & 0,011 & 0,034 & 0,021 & 0,026 & 0,009 \\
\hline $\mathbf{M g}$ & 0,806 & 0,790 & 0,807 & 0,785 & 0,792 & 0,781 & 0,784 & 0,656 & 0,590 & 0,626 & 0,652 & 0,645 & 0,650 & 0,713 & 0,664 \\
\hline $\mathrm{Fe}^{2+}$ & 0,115 & 0,145 & 0,114 & 0,097 & 0,071 & 0,115 & 0,062 & 0,278 & 0,391 & 0,299 & 0,298 & 0,292 & 0,297 & 0,227 & 0,279 \\
\hline $\mathrm{Mn}$ & 0,000 & 0,000 & 0,000 & 0,000 & 0,000 & 0,000 & 0,000 & 0,000 & 0,000 & 0,000 & 0,000 & 0,000 & 0,000 & 0,000 & 0,000 \\
\hline$S O M A-M I 1$ & 1,000 & 1.000 & 1,000 & 1,000 & 1,000 & 1,000 & 1,000 & 1,000 & 1,000 & 1,000 & 1,000 & 1,000 & 1,000 & 1,000 & 1,000 \\
\hline $\mathbf{M g}$ & 0,000 & 0,000 & 0,000 & 0,000 & 0,000 & 0,000 & 0,000 & 0,000 & 0,000 & 0,000 & 0,000 & 0,000 & 0,000 & 0,000 & 0,000 \\
\hline $\mathrm{Fe} 2$ & 0,115 & 0,088 & 0,109 & 0,064 & 0,116 & 0,060 & 0,106 & 0,131 & 0,099 & 0,141 & 0,134 & 0,122 & 0,118 & 0,139 & 0,148 \\
\hline $\mathrm{Mn}$ & 0,012 & 0,011 & 0,013 & 0,010 & 0,009 & 0,009 & 0,008 & 0,022 & 0,022 & 0,023 & 0,021 & 0,019 & 0,021 & 0,018 & 0,023 \\
\hline $\mathrm{Ca}$ & 0,842 & 0,872 & 0,849 & 0,896 & 0,824 & 0,902 & 0,837 & 0,818 & 0,850 & 0,807 & 0,816 & 0,830 & 0,834 & 0,817 & 0,798 \\
\hline $\mathrm{Na}$ & 0,031 & 0,028 & 0,029 & 0,030 & 0,046 & 0,028 & 0,047 & 0,030 & 0,024 & 0,030 & 0,029 & 0,028 & 0,027 & 0,026 & 0,031 \\
\hline K & 0,000 & 0,000 & 0,000 & 0,000 & 0,005 & 0,001 & 0,002 & 0,000 & 0,000 & 0,000 & 0,000 & 0,001 & 0,000 & 0,000 & 0,000 \\
\hline$O M A-M 2$ & 1,000 & 1,000 & 1,000 & 1,000 & 1,000 & 1,000 & $l, 000$ & 1,000 & 0,994 & 1,000 & 1,000 & 1,000 & 1,000 & 1,000 & 1,000 \\
\hline$m g \#$ & 0,778 & 0,772 & 0,783 & 0,830 & 0,809 & 0,817 & 0,823 & 0,616 & 0,546 & 0,588 & 0,601 & 0,609 & 0,610 & 0,660 & 0,609 \\
\hline
\end{tabular}

Obs: 1 - $\mathrm{Fe}_{2} \mathrm{O}_{3}$ e FeO calculados pelo método de Droop (1987).

2- N, núcleo; 1 , região intermediária; $B$, borda; pt, ponto analisado.

3-<L. D.: abaixo do limite de deteccão.

4- $\mathrm{mg} \#=\mathrm{Mg} /\left(\mathrm{Mg}+\mathrm{Fe}^{2+}\right)$. 
Tabela V.2. Continuação

Fácies

Rocha Hibrida

Amostra

Análise ptl/grão2 pt2/grão2 pt3/grão2 pt4/grão2 pt5/grão2

Localização N-I

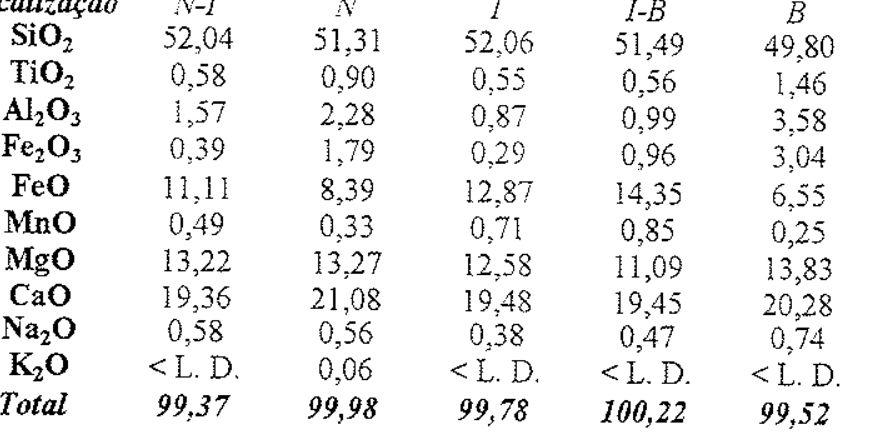

Fórmula estrutural com base em 6 oxigênios e 4 cátions

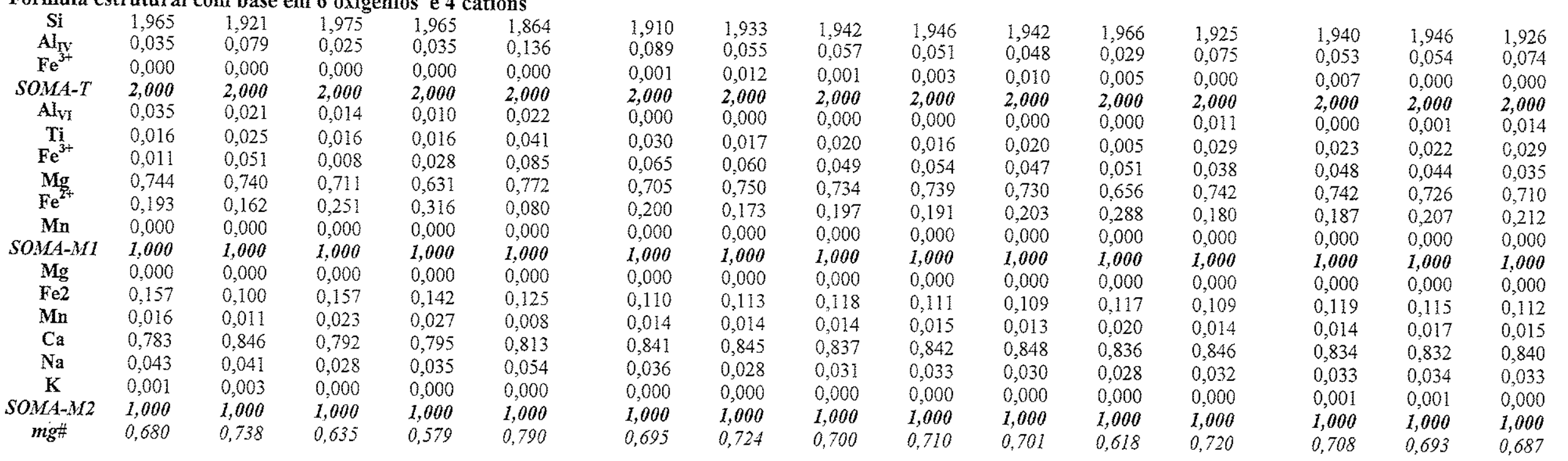

Obs: $1-\mathrm{Fe}_{2} \mathrm{O}_{3}$ e FeO calculados pelo método de Droop (1987).

$2-\mathrm{N}$, núcleo; I, região intermediária; $\mathrm{B}$, borda; $\mathrm{t}$, ponto analisado.

3-< L. D.: abaixo do limite de deteccão.

4. $\mathrm{mg} \#=\mathrm{Mg} /\left(\mathrm{Mg}+\mathrm{Fe}^{2 \div}\right)$.

ptl/grãol pt2/grãol pt3/gräol pt4/grãol pt5/grãol pto/grãol pt8/grãol

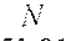

51,80

$I$

$I-B$

$B$
51,25

$1,07 \quad 0,61$$$
2,01
$$

2,35

9,84
0,45

12,57

20,86

0,49

$<$ L. D$$
\begin{aligned}
& 0,61 \\
& 1,24 \\
& 2,54
\end{aligned}
$$

$$
2,54
$$$$
0,43
$$$$
13,31
$$$$
20,88
$$$$
0,38
$$

$<$ L. D
99.56

0,71$$
\begin{aligned}
& 1,29 \\
& 1,79
\end{aligned}
$$$$
10,04
$$$$
0,43
$$

13,13
20,85

0,42

$<\mathrm{L} . \mathrm{D}$.
100,48

0,58

1,16
2,01

$$
9,61
$$

0,46

13,19

20,91
0,45

$<\mathrm{L}$. D

$$
\begin{gathered}
51,91 \\
0,72
\end{gathered}
$$

1,08

2,04
9,95

0,42

13,09
21,14

21,14
0,42

< L. D.

51,83

1,02

$1,97 \quad 1,33$

$12,76 \quad 9,19$

$0,62 \quad 0,44$

$11,60 \quad 13,25$

$20,56 \quad 21,01$

0,37

$<$ L. D.

0,44
$<1.0$.

99,85

Diorito

22

ptl/grãol pt2/grãoz pt3/grão2

$\begin{array}{ccc}N & N-1 & N-I\end{array}$

$\begin{array}{lll}0,81 & 0,80 & 1,03\end{array}$

$\begin{array}{lll}1,20 & 1,26 & 1,98\end{array}$

$1,97 \quad 1,56 \quad 1,22$

$9,80 \quad 10,31 \quad 10,30$

$\begin{array}{lll}0,45 & 0,55 & 0,48\end{array}$

$13,32 \quad 13,03 \quad 12,68$

$20,82 \quad 20,78 \quad 20,87$

$\begin{array}{rrr}0,45 & 0,47 & 0,45\end{array}$

<L. D. <L. D. < $\quad$ D. D.

$100,74 \quad 100,85 \quad 100,29$

0,708

0,693

0,687 
Tabela V.2. Continuação

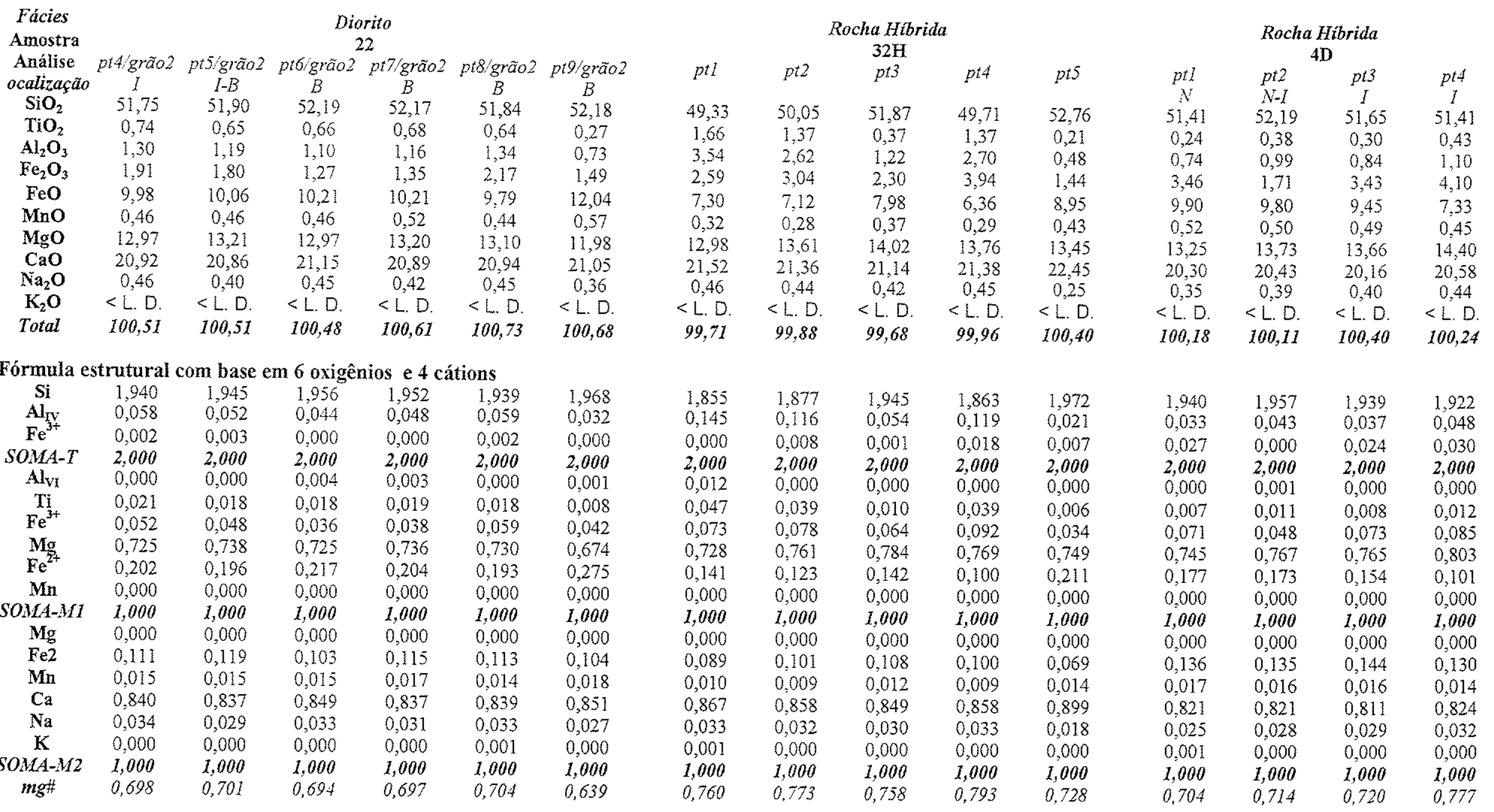

Obs: 1- $\mathrm{Fe}_{2} \mathrm{O}_{3}$ e FeO calculados pelo método de Droop (1987).

$2-N$, núcleo; 1 , tegião intermediária; $B$, borda; $p t$, ponto analisado.

3-<L. D.: abaixo do limite de detecção.

4- $\mathrm{mg} \#=\mathrm{Mg} /\left(\mathrm{Mg}+\mathrm{Fe}^{2+}\right)$. 
Tabela V.2. Continuação

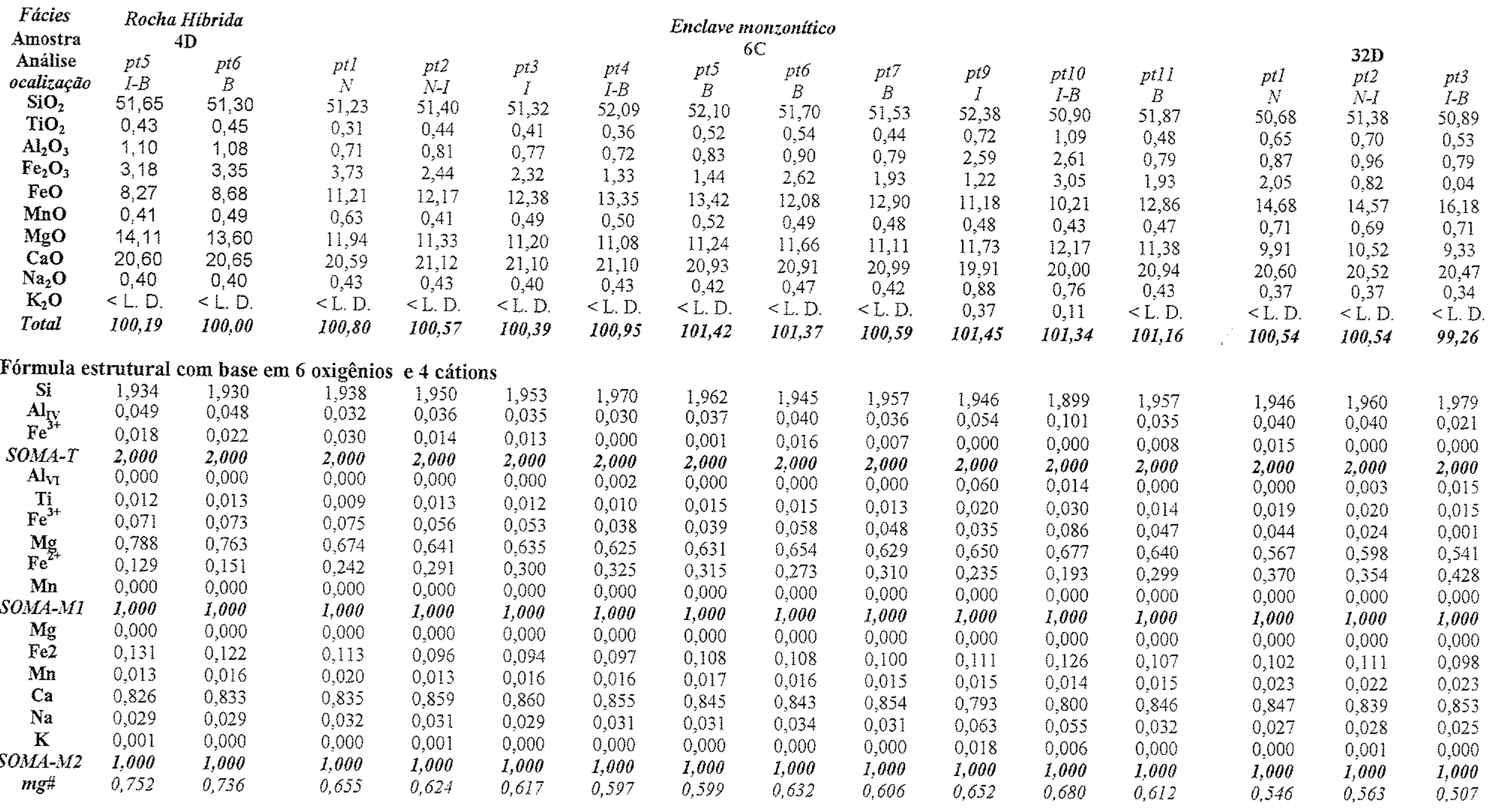

Obs: $1-\mathrm{Fe}_{2} \mathrm{O}_{3}$ e FeO calculados pelo método de Droop (1987).

$2-\mathrm{N}$, núcleo; 1 , região intermediária; $\mathrm{B}$, borda; pt, ponto analisado.

$3-<$ L. D.: abaixo do limite de detecção.

4. $\mathrm{mg} \#=\mathrm{Mg} /\left(\mathrm{Mg}+\mathrm{Fe}^{2+}\right)$. 
Tabela V.2. Continuação

Fácies

Amostra

Analise pt5

$\begin{array}{lcc}\mathrm{SiO}_{2} & 50,17 & B \\ & & 51,2 \mathrm{I}\end{array}$

$\begin{array}{lll}\mathrm{TiO}_{2} & 0,77 & 0,68\end{array}$

$\begin{array}{lll}\mathrm{Al}_{2} \mathrm{O}_{3} & 0,77 & 0,85\end{array}$

$\mathrm{Fe}_{2} \mathrm{O}_{3} \quad 1,71$

$\mathrm{FeO} \quad 15,66$

MnO $\quad 0,68$

$\mathrm{MgO} \quad 9,07$

$\begin{array}{cc}\mathrm{CaO} & 20,62 \\ \mathrm{Na}_{2} \mathrm{O} & 0,38\end{array}$

$\mathrm{K}_{2} \mathrm{O}<\mathrm{L}$. D

Total 99,83

9,50
20,54

0,42

$<$ L. D.

100,59
Melasienito

$\begin{array}{ccc}\text { pt6 } & \text { ptT } & p t 8 \\ I-B & B & I \\ 50,92 & 49,89 & 51,50 \\ 0,67 & 0,68 & 0,58 \\ 0,96 & 0,79 & 0,92 \\ 1,18 & 2,11 & 0,77 \\ 14,23 & 14,86 & 14,83 \\ 0,78 & 0,71 & 0,76 \\ 10,47 & 9,30 & 10,38 \\ 20,47 & 20,52 & 20,59 \\ 0,34 & 0,40 & 0,35 \\ <\mathrm{L} . \mathrm{D} . & <\mathrm{L} . \mathrm{D} . & <\mathrm{L} . \mathrm{D} . \\ 100,02 & 99,25 & 100,67\end{array}$

Fórmula estrutural com base em 6 oxigênios e 4 cátions

\begin{tabular}{|c|c|c|c|c|c|}
\hline $\mathrm{Si}$ & 1,949 & 1,966 & 1,954 & 1,946 & 1,965 \\
\hline $\mathrm{Al}_{\mathrm{rV}}$ & 0,035 & 0,034 & 0,043 & 0,036 & 0,035 \\
\hline $\mathrm{Fe}^{3+}$ & 0,016 & 0,000 & 0,002 & 0,018 & 0,000 \\
\hline$S O M A A-T$ & 2,000 & 2,000 & 2,000 & 2,000 & 2,000 \\
\hline $\mathrm{Al}_{\mathrm{VI}}$ & 0,000 & 0,004 & 0,000 & 0,000 & 0,006 \\
\hline $\mathbf{T i}_{3+}$ & 0,022 & 0,020 & 0,019 & 0,020 & 0,017 \\
\hline $\mathrm{Fe}^{3+}$ & 0,034 & 0,022 & 0,032 & 0,044 & 0,022 \\
\hline $\mathrm{Mg}$ & 0,525 & 0,544 & 0,599 & 0,541 & 0,590 \\
\hline $\mathrm{Fe}^{2+}$ & 0,418 & 0,410 & 0,349 & 0,396 & 0,365 \\
\hline Mn & 0,000 & 0,000 & 0,000 & 0,000 & 0,000 \\
\hline$S O M A-M I$ & 1,000 & 1,000 & 1,000 & 1,000 & 1,000 \\
\hline $\mathbf{M g}$ & 0,000 & 0,000 & 0,000 & 0,000 & 0,000 \\
\hline $\mathrm{Fe} 2$ & 0,091 & 0,100 & 0,108 & 0,089 & 0,108 \\
\hline $\mathrm{Mn}$ & 0,023 & 0,024 & 0,025 & 0,023 & 0,025 \\
\hline $\mathrm{Ca}$ & 0,858 & 0,845 & 0,842 & 0,858 & 0,842 \\
\hline $\mathrm{Na}$ & 0,028 & 0,032 & 0,025 & 0,030 & 0,026 \\
\hline K & 0,000 & 0,000 & 0,000 & 0,000 & 0,000 \\
\hline$S O M A-M 2$ & 1,000 & 1,000 & 1,000 & 1,000 & 1,000 \\
\hline$m g \#$ & 0,508 & 0,516 & 0,567 & 0,527 & 0,55 \\
\hline
\end{tabular}

Obs: $1-\mathrm{Fe}_{2} \mathrm{O}_{3}$ e $\mathrm{FeO}$ calculados pelo método de Droop (1987).

$2-N$, núcleo; $I$, região intermediária; $B$, borda; $p t$, ponto analisado.

3-< L. D.: abaixo do limite de deteç̧ão.

4- $\mathrm{mg} \#=\mathrm{Mg} /\left(\mathrm{Mg}+\mathrm{Fe}^{2+}\right)$.
Sienito Róseo Grosso

$$
51
$$

ptligrãol ptzigrãol pt3̧grãol

\begin{tabular}{|c|c|c|}
\hline$N$ & $N-I$ & I \\
\hline 50,43 & 50,68 & 51,01 \\
\hline 0,62 & 0,59 & 0,52 \\
\hline 0,63 & 0,77 & 0,77 \\
\hline 0,80 & 1,42 & 0,86 \\
\hline 19,01 & 16,92 & 17,07 \\
\hline 0,90 & 0,88 & 0,81 \\
\hline 7,28 & 8,65 & 8,70 \\
\hline 20,43 & 20,35 & 20,54 \\
\hline 0,38 & 0,39 & 0,38 \\
\hline$<\mathrm{L} . \mathrm{D}$. & $<$ L. D. & $<\mathrm{L} . \mathrm{D}$. \\
\hline
\end{tabular}

$\begin{array}{ccccc}\text { pt4igrãol } & \text { pt5/grãol } & \text { pt6/gräol } & \text { pt7.grãol } & \text { pt8/grãol } \\ \text { I-B } & I & B & B & B \\ 51,14 & 50,68 & 50,62 & 49,14 & 49,70 \\ 0,02 & 0,57 & 0,61 & 0,32 & 0,34 \\ 0,25 & 0,76 & 0,67 & 0,27 & 0,28 \\ 2,17 & 1,62 & 0,94 & 2,46 & 1,56 \\ 18,59 & 16,65 & 17,68 & 21,10 & 21,60 \\ 0,94 & 0,89 & 0,97 & 0,93 & 0,97 \\ 5,73 & 8,74 & 8,07 & 4,93 & 4,85 \\ 21,10 & 20,49 & 20,52 & 20,27 & 20,41 \\ 0,95 & 0,37 & 0,38 & 0,48 & 0,50 \\ \text { <L.D. } & <\mathrm{L} . \mathrm{D} . & <\mathrm{L} . \mathrm{D} . & <\mathrm{L} . \mathrm{D} . & <\mathrm{L} . \mathrm{D} . \\ 100,88 & 100,79 & 100,46 & 99,90 & 100,22\end{array}$

$0,029-1,959$

$0,001 \quad 0,005$

$2,000 \quad 2,000$

$0,000 \quad 0,000$

$\begin{array}{ll}0,018 & 0,017 \\ 0,023 & 0,036\end{array}$

$0,424 \quad 0,498$

$0,535 \quad 0,448$

$0,000 \quad 0,000$

$1,000 \quad 1,000$

$0,000 \quad 0,000$

$0,086 \quad 0,099$

$0,030 \quad 0,029$

$0,855 \quad 0,843$

$0,029 \quad 0,029$

$0,000 \quad 0,000$

$\begin{array}{ll}0,406 & 0,477\end{array}$
1,969
0,031
0,000
2,000
0,004
0,015
0,025
0,500
0,455
0,000
1,000
0,000
0,096
0,026
0,850
0,028
0,000
1,000
0,476

\section{1,998}

0,002

0,000

2,000

0,009

0,001

0,063

0,333

0,593

0,000

1,000

0,000

0,014

0,031

0,883

0,072

0,000

1,000

0,354

$$
\begin{aligned}
& 1,956 \\
& 0,035 \\
& 0,009 \\
& 2,000 \\
& 0,000 \\
& 0,017 \\
& 0,038 \\
& 0,503 \\
& 0,442 \\
& 0,000 \\
& 1,000 \\
& 0,000 \\
& 0,095 \\
& 0,029 \\
& 0,847 \\
& 0,028 \\
& 0,000 \\
& 1,000 \\
& 0,483
\end{aligned}
$$

1,967

0,031

0,002

2,000
0,000

0,000
0,018

0,025

0,467

0,489

0,000

1,000

0,000

0,085

0,032

0,854

0,028

0,000

1,000

0,449
1,966

0,013

0,021

2,000

0,000

0,010

0,052

0,294

0,644

0,000
1,000

0,000

0,062

0,031
0,869

0,037

0,000

1,000

0,294

\section{1,980}

0,013

2,008

2,000

0,000
0,010

0,039

0,288

0,663

1,000

0,000

0,057

0,033

0,871

0,000

1,000

0,286 
Tabela V.2. Continuação

Fácies

Amostra

Análise ptl/grão2 pt2/grão2 pt3/grão2 pt4/grão2 pt5/grão2 pt6/grão2 pt7/grão2 51

\begin{tabular}{|c|c|c|c|c|c|c|c|c|c|c|c|c|c|c|}
\hline ocalizaca & & $I$ & $I$ & $y$ & $y$ & $y y$ & & & & & & & & \\
\hline $\mathrm{SiO}_{2}$ & 50,37 & 50,19 & 50,64 & 50,18 & 50,73 & $\begin{array}{l}7-7 \\
50.77\end{array}$ & 51.20 & $I-B$ & $I-B$ & $B$ & $I-B$ & I & $I-B$ & $B$ \\
\hline $\mathrm{TiO}_{2}$ & 0,59 & 0,56 & 0,63 & 0,57 & 0,00 & 0.14 & $\begin{array}{l}31,20 \\
027\end{array}$ & 49,94 & & & & 49,92 & 49,97 & 49,77 \\
\hline $\mathrm{Al}_{2} \mathrm{O}_{3}$ & 0,58 & 0,63 & 0,64 & 0,62 & 0,17 & 0,5 & $\begin{array}{l}0,21 \\
015\end{array}$ & 0,26 & 0,53 & 0,55 & 0,42 & 0,44 & 0,29 & 0,44 \\
\hline $\mathrm{Fe}_{2} \mathrm{O}_{3}$ & 0,71 & 1,75 & 0,89 & 1,24 & 2,49 & 4.26 & $\begin{array}{l}0,15 \\
3,98\end{array}$ & 0,26 & 0,64 & 0,56 & 0,50 & 0,43 & 0,40 & 0,35 \\
\hline $\mathrm{FeO}$ & 20,25 & 18,24 & 18,83 & 18,56 & 1720 & 1748 & 3,98 & 2,03 & 0,38 & 0,63 & 1,14 & 1,26 & 1,17 & 1,32 \\
\hline $\mathrm{MnO}$ & 0,89 & 0,93 & 0.87 & 100 & 096 & 090 & 17,66 & 20,75 & 19,22 & 19,69 & 20,33 & 20,91 & 21,44 & 21,47 \\
\hline $\mathrm{MgO}$ & 6,69 & 7,58 & 7,49 & 7,36 & 6.53 & $\begin{array}{l}0,90 \\
545\end{array}$ & 0,84 & 0,91 & 0,99 & 0,92 & 0,85 & 0,94 & 0,90 & 0,98 \\
\hline $\mathrm{CaO}$ & 20,39 & 20,16 & 20,56 & 20,39 & 21,73 & $\begin{array}{c}2,45 \\
20,14\end{array}$ & 4,63 & 5,51 & 7,12 & 6,65 & 6,20 & 5,72 & 5,41 & 5,10 \\
\hline $\mathrm{Na}_{2} \mathrm{O}$ & 0,34 & 0,43 & 0,37 & 0,37 & 0,65 & $\begin{array}{c}20,14 \\
1,49\end{array}$ & 19,02 & 19,76 & 20,55 & 20,45 & 20,44 & 20,37 & 20,28 & 20,48 \\
\hline $\mathrm{K}_{2} \mathrm{O}$ & $<\mathrm{L}$. D. & $<$ L. D. & $<\mathrm{L} . \mathrm{D}$. & $<$ L. D. & $<\mathrm{L} . \mathrm{D}$. & $<\mathrm{L} . \mathrm{D}$ & $\begin{array}{r}2,22 \\
\end{array}$ & 0,68 & 0,42 & 0,38 & 0,34 & 0,41 & 0,44 & 0,46 \\
\hline Total & 100,80 & 100,48 & 100,93 & 100,30 & 100,46 & 100,78 & $\begin{array}{l}\text { L. D. } \\
99.91\end{array}$ & $\begin{array}{l}<\text { L.D. } \\
100.10\end{array}$ & $\begin{array}{l}<\text { L. D. } \\
100.65\end{array}$ & $<$ L. D. & <L. D. & <L. D. & $\begin{array}{l}<\mathrm{L} \text {. D. } \\
\text {. } 30 .\end{array}$ & <L. D. \\
\hline \multicolumn{15}{|c|}{ órmula estrutural com base em 6 oxigênios e 4 cátions } \\
\hline $\mathrm{Si}$ & 1,972 & 1,959 & 1,968 & 1,964 & 1,984 & 1,986 & 2,016 & 1,982 & 1,980 & 1,976 & 1.972 & 1974 & 1981 & 1,976 \\
\hline $\mathbf{A l}_{\mathrm{NV}}$ & 0,027 & 0,029 & 0,029 & 0,029 & 0,008 & 0,007 & 0,000 & 0,012 & 0,020 & 0,024 & 0,023 & 0,020 & 0,019 & 0,016 \\
\hline $\mathrm{Fe}^{3+}$ & 0,001 & 0,011 & 0,003 & 0,007 & 0,008 & 0,007 & 0,000 & 0,006 & 0,000 & 0,000 & 0,005 & 0,006 & 0,000 & 0,007 \\
\hline SOMA-T & 2,000 & 2,000 & 2,000 & 2,000 & 2,000 & 2,000 & 2,016 & 2,000 & 2,000 & 2,000 & 2,000 & 2,000 & 2,000 & 2,000 \\
\hline $\mathrm{Al}_{\mathrm{Vx}}$ & 0,000 & 0,000 & 0,000 & 0,000 & 0,000 & 0,000 & 0,007 & 0,000 & 0,010 & 0,002 & 0,000 & 0,000 & 0,000 & 0,000 \\
\hline $\mathrm{Ti}$ & 0,017 & 0,017 & 0,019 & 0,017 & 0,000 & 0,004 & 0,006 & 0,008 & 0,016 & 0,016 & 0,012 & 0,013 & 0,009 & 0,013 \\
\hline $\mathrm{Fe}^{3+}$ & 0,019 & 0,040 & 0,023 & 0,030 & 0,065 & 0,117 & 0,117 & 0,054 & 0,011 & 0,019 & 0,029 & 0,032 & 0,035 & 0,032 \\
\hline $\mathrm{Mg}$ & 0,390 & 0,441 & 0,434 & 0,430 & 0,381 & 0,318 & 0,271 & 0,326 & 0,414 & 0,391 & 0,366 & 0,337 & 0,320 & 0,302 \\
\hline $\mathrm{Fe}^{2+}$ & 0,573 & 0,502 & 0,524 & 0,524 & 0,555 & 0,561 & 0,583 & 0,612 & 0,550 & 0,572 & 0,593 & 0,618 & 0,636 & 0,652 \\
\hline Mn & 0,000 & 0,000 & 0,000 & 0,000 & 0,000 & 0,000 & 0,016 & 0,000 & 0,000 & 0,000 & 0,000 & 0,000 & 0,000 & 0,000 \\
\hline$O M A-M I$ & 1,000 & 1,000 & 1,000 & 1,000 & 1,000 & 1,000 & 1,000 & 1,000 & 1,000 & 1,000 & 1,000 & 1,000 & 1,000 & 1,000 \\
\hline Mg & 0,000 & 0,000 & 0,000 & 0,000 & 0,000 & 0,000 & 0,000 & 0,000 & 0,000 & 0,000 & 0,000 & 0,000 & 0,000 & 0,000 \\
\hline $\mathrm{Fe} 2$ & 0,090 & 0,093 & 0,087 & 0,084 & 0,009 & 0,013 & 0,000 & 0,077 & 0,077 & 0,077 & 0,080 & 0,074 & 0,074 & 0,061 \\
\hline Mn & 0,030 & 0,031 & 0,029 & 0,033 & 0,032 & 0,030 & 0,012 & 0,031 & 0,033 & 0,031 & 0,028 & 0,032 & 0,030 & 0,033 \\
\hline $\mathrm{Ca}$ & 0,855 & 0,843 & 0,856 & 0,855 & 0,910 & 0,844 & 0,802 & 0,840 & 0,858 & 0,864 & 0,866 & 0,863 & 0,861 & 0,871 \\
\hline $\mathbf{N a}$ & 0,026 & 0,033 & 0,028 & 0,028 & 0,049 & 0,113 & 0,169 & 0,052 & 0,032 & 0,029 & 0,026 & 0,031 & 0,033 & 0,035 \\
\hline K & 0,000 & 0,000 & 0,000 & 0,000 & 0,000 & 0,000 & 0,000 & 0,000 & 0,000 & 0,000 & 0,000 & 0,001 & 0,000 & 0,000 \\
\hline$O M A-M 2$ & 1,000 & 1,000 & 1,000 & 1,000 & 1,000 & 1,000 & 0,984 & 1,000 & 1,000 & 1,000 & 1,000 & 1,000 & 1,000 & 1,000 \\
\hline$m g \#$ & 0,370 & 0,425 & 0,415 & 0.414 & 0,403 & 0,357 & 0,318 & 0,321 & 0,398 & 0,376 & 0,352 & 0,328 & 0,310 & 0,298 \\
\hline
\end{tabular}

Obs: $1-\mathrm{Fe}_{2} \mathrm{O}_{3}$ e FeO calculados pelo método de Droop (1987)

$2-\mathrm{N}$, núcleo; $\mathrm{I}$, região intermediária; $\mathrm{B}$, borda; pt, ponto analisado.

3-< L. D. abaixo do limite de deteccão.

4. $\mathrm{mg} \#=\mathrm{Mg} /\left(\mathrm{Mg}+\mathrm{Fe}^{2+}\right)$. 
Tabela V.2. Continuação

Fácies Sienito Róseo Grosso

Amostra

Análise pt2/grão3 pt3/grão3 pt4/grão3 pt5/grão3

acalização

$\begin{array}{ccccc}\text { acalizaçao } & & & & \\ \mathrm{SiO}_{2} & 50,01 & 50,01 & 50,01 & 49,54 \\ \mathrm{TiO}_{2} & 0,40 & 0,60 & 0,60 & 0,49 \\ \mathbf{A l}_{2} \mathbf{O}_{3} & 0,42 & 0,69 & 0,69 & 0,42 \\ \mathrm{Fe}_{2} \mathbf{O}_{3} & 1,18 & 1,95 & 1,31 & 1,99 \\ \mathrm{FeO} & 20,84 & 17,29 & 17,79 & 20,35 \\ \mathrm{MnO} & 0,85 & 0,84 & 0,92 & 0,97 \\ \mathrm{MgO} & 5,64 & 7,69 & 7,53 & 5,66 \\ \mathbf{C a O} & 20,53 & 20,61 & 20,39 & 20,40 \\ \mathbf{N a} \mathbf{O} & 0,45 & 0,45 & 0,45 & 0,46 \\ \mathbf{K}_{2} \mathbf{O} & <\mathrm{L} . \mathrm{D} . & <\mathrm{L} . \mathrm{D} . & <\mathrm{L} . \mathrm{D} . & <\mathrm{L} . \mathrm{D} . \\ \text { Total } & 100,32 & 100,14 & 99,68 & 100,28\end{array}$

Sienito Róseo Fino

$\begin{array}{cc}p t 1 & p t 2 \\ N & N-1 \\ 48,19 & 49,50 \\ 0,77 & 0,60 \\ 0,60 & 0,59 \\ 2,42 & 1,21 \\ 20,41 & 21,86 \\ 0,99 & 1,00 \\ 4,79 & 4,89 \\ 20,57 & 20,43 \\ 0,43 & 0,43 \\ \text { <. D. } & <\mathrm{L} . \mathrm{D} \\ \text { 99,17 } & 100,51\end{array}$

Fórmula estrutural com base em 6 oxigênios e 4 cátions

\begin{tabular}{|c|c|c|c|c|c|c|}
\hline & & & & & & \\
\hline $\mathrm{Al}_{\mathrm{Y}}$ & $\begin{array}{l}1,978 \\
0,010\end{array}$ & 1,955 & 1,964 & 1,963 & 1,943 & 1,96 \\
\hline $\mathrm{Fe}^{3+}$ & 0,019 & 0,032 & 0,032 & 0,020 & 0,029 & 00 \\
\hline SOMA-T & 0,002 & 0,013 & 0,004 & 0,017 & 0,029 & 0,00 \\
\hline $\mathrm{Al}_{\mathrm{VI}}$ & & 2,000 & 2,000 & 2,000 & 2,000 & 2,0 \\
\hline & & 0,000 & 0,000 & 0,000 & 0,000 & \\
\hline$\underset{\mathrm{Fe}^{3+}}{\mathrm{Ti}}$ & 0,012 & 0,018 & 0,018 & 0,015 & 0,023 & 0,0 \\
\hline $\mathrm{Fe}^{3+}$ & 0,033 & 0,044 & 0,034 & 0,042 & 0,044 & \\
\hline $\mathbf{M g}$ & 0,333 & 0,448 & 0,441 & 0,335 & 0,288 & 0 \\
\hline $\mathrm{Fe}^{27+}$ & 0,623 & 0,490 & 0,507 & 0,608 & 0,645 & 0,6 \\
\hline $\mathbf{M n}$ & 0,000 & 0,000 & 0,000 & 0,000 & 0,000 & 0,0 \\
\hline SOMA-MI & 1,000 & 1,000 & 1,000 & 1,000 & 1,000 & \\
\hline Mg & 0,000 & 0,000 & 0,000 & 0,000 & 0,000 & 0,0 \\
\hline $\mathrm{Fe} 2$ & 0,067 & 0,075 & 0,077 & 0,066 & 0,044 & 0,0 \\
\hline $\mathrm{Mn}$ & 0,028 & 0,028 & 0,031 & 0,033 & 0,034 & 0,0 \\
\hline $\mathrm{Ca}$ & 0,870 & 0,863 & 0,858 & 0,866 & 0,888 & 0, \\
\hline $\mathrm{Na}$ & 0,035 & 0,034 & 0,034 & 0,035 & 0,034 & 0,0 \\
\hline K & 0,000 & 0,000 & 0,000 & 0,000 & 0,000 & 0,0 \\
\hline SOMA-M2 & 1,000 & 1,000 & 1,000 & 1,000 & 1,000 & \\
\hline$m g \#$ & 0,326 & 0,442 & 0,430 & 0.332 & 0,295 & \\
\hline
\end{tabular}

Obs: $1-\mathrm{Fe}_{2} \mathrm{O}_{3}$ e FeO calculados pelo método de Droop (1987).

2- N, núcleo; $I$, região intermediária: $B$, borda; pt, ponto analisado.

3-< L. D.: abaixo do limite de detecção.

4- $\mathrm{mg} \#_{\#=\mathrm{Mg}} /\left(\mathrm{Mg}+\mathrm{Fe}^{2+}\right)$.

$$
403
$$$$
\text { pt3 pt4 }
$$$$
49,24
$$$$
0,60
$$$$
0,52
$$$$
1,47
$$$$
21,15
$$$$
1,09
$$$$
4,92
$$$$
20,71
$$$$
0,40
$$$$
\begin{aligned}
& <\mathrm{L} . \mathrm{D} \text {. } \\
& 100.10
\end{aligned}
$$

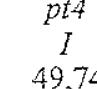

49,74
0,55

$$
0,49
$$$$
\begin{array}{r}
0,81 \\
22,70
\end{array}
$$$$
0,94
$$$$
4,57
$$$$
20,47
$$$$
0,42
$$

Sienito Verde Grosso

$\begin{array}{cc}p t 5 & p t 6 \\ I-B & B \\ 48,46 & 48,66 \\ 0,45 & 0,33 \\ 0,38 & 0,23 \\ 2,46 & 1,87 \\ 22,07 & 24,14 \\ 1,18 & 0,96 \\ 3,66 & 2,46 \\ 20,49 & 19,73 \\ 0,50 & 0,80 \\ \text { L. D. } & <\text { L. D. } \\ 99,64 & 99,18\end{array}$

$p t I$
$N-I$
49,29
0,77
0,75
2,28
20,46
1,05
5,29
20,29
0,38
$<$ L. D
100,55

$\begin{array}{cccc}\text { pt2 } & 1 & & \\ I & p t 3 & p t 4 & p t 5 \\ 49,74 & I & B & B \\ 0,64 & 49,56 & 49,26 & 49,35 \\ 0,75 & 0,12 & 0,19 & 0,12 \\ 2,25 & 0,26 & 0,14 & 0,13 \\ 20,16 & 2,51 & 2,70 & 2,72 \\ 1,06 & 22,50 & 24,29 & 24,46 \\ 5,20 & 0,96 & 1,09 & 1,05 \\ 20,22 & 2,29 & 1,12 & 1,21 \\ 0,36 & 20,05 & 17,65 & 17,87 \\ <\mathrm{L} . \mathrm{D} . & <\mathrm{L} . \mathrm{D} . & <\mathrm{L} . \mathrm{D} . & <\mathrm{L} . \mathrm{D} . \\ 100,38 & 99,36 & 98,45 & 98,84 \\ & & & \end{array}$

$\begin{array}{llll}1,963 & 1,976 & 1,959 & 1,987 \\ 0,025 & 0,023 & 0,018 & 0,011 \\ 0,012 & 0,001 & 0,023 & 0,002 \\ 2,000 & 2,000 & 2,000 & 2,000 \\ 0,000 & 0,000 & 0,000 & 0,000 \\ 0,018 & 0,016 & 0,014 & 0,010 \\ 0,032 & 0,024 & 0,052 & 0,056 \\ 0,293 & 0,271 & 0,221 & 0,150 \\ 0,658 & 0,689 & 0,714 & 0,785 \\ 0,000 & 0,000 & 0,000 & 0,000 \\ 1,000 & 1,000 & 1,000 & 1,000 \\ 0,000 & 0,000 & 0,000 & 0,000 \\ 0,048 & 0,065 & 0,033 & 0,040 \\ 0,037 & 0,032 & 0,040 & 0,033 \\ 0,885 & 0,871 & 0,888 & 0,863 \\ 0,031 & 0,033 & 0,039 & 0,063 \\ 0,000 & 0,000 & 0,000 & 0,000 \\ 1,000 & 1,000 & 1,000 & 1,000 \\ 0,293 & 0,264 & 0,228 & 0,153\end{array}$

1,952

1,973

0,027

$2,008 \quad 2,021 \quad 2,016$

$0,000 \quad 0,000 \quad 0,000$

$\begin{array}{llll}0,013 & 0,000 & 0,000 & 0,000\end{array}$

$\begin{array}{lllll}2,000 & 2,000 & 2,000 & 2,000 & 2,000 \\ 0,000 & 0,007 & 0,020 & 0,028 & 0,022\end{array}$

$\begin{array}{lllll}0,023 & 0,019 & 0,004 & 0,006 & 0,004\end{array}$

$\begin{array}{lllll}0,031 & 0,010 & 0,052 & 0,097 & 0,106\end{array}$

$\begin{array}{lllll}0,312 & 0,307 & 0,139 & 0,068 & 0,074\end{array}$

$\begin{array}{lllll}0,634 & 0,656 & 0,786 & 0,801 & 0,794\end{array}$

$\begin{array}{lllll}0,000 & 0,000 & 0,000 & 0,000 & 0,000\end{array}$

$\begin{array}{lllll}1,000 & 1,000 & 1,000 & 1,000 & 1,000\end{array}$

$\begin{array}{lllll}0,000 & 0,000 & 0,000 & 0,000 & 0,000\end{array}$

$\begin{array}{lllll}0,075 & 0,077 & 0,010 & 0,028 & 0,028\end{array}$

$\begin{array}{lllll}0,075 & 0,077 & 0,010 & 0,028 & 0,028 \\ 0,035 & 0,035 & 0,033 & 0,038 & 0,036\end{array}$

$\begin{array}{lllll}0,035 & 0,035 & 0,033 & 0,038 & 0,036 \\ 0,861 & 0,859 & 0,870 & 0,776 & 0,782\end{array}$

$\begin{array}{lllll}0,029 & 0,028 & 0,087 & 0,158 & 0,153\end{array}$

$\begin{array}{lllll}0,000 & 0,001 & 0,001 & 0,000 & 0,000\end{array}$

$\begin{array}{lllll}1,000 & 1,000 & 1,000 & 1,000 & 1,000\end{array}$

$\begin{array}{lllll}0,306 & 0,295 & 0,148 & 0,076 & 0,082\end{array}$ 
Tabela V.2. Continuação

Fácies

Amostra

Análise 1

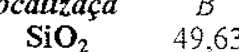

2,73

$\mathrm{FeO} \quad 24,51$

MnO 0,83

$\mathrm{MgO} \quad 1,51$

$\mathrm{CaO} \quad 18,51$

$\quad \mathrm{Na}_{2} \mathrm{O} \quad 1,65$

$\begin{array}{rr}\mathrm{K}_{2} \mathrm{O} & <\mathrm{L} . \mathrm{D} \\ \text { Total } & 99.63\end{array}$
Analise $\quad p t 6$

(1,

Sienito Verde Grosso

$\begin{array}{ccc}\text { ptl/grãol } & \text { pt2grãol } & \text { pt3/grãol } \\ \text { N-I } & \text { N-I } & I\end{array}$

$\begin{array}{cccc}N-I & N-I & I & I \\ 49,51 & 49,13 & 48,96 & 49,13 \\ 0,82 & 0,71 & 0,80 & 0,81 \\ 0,66 & 0,62 & 0,65 & 0,67 \\ 0,42 & 0,59 & 0,46 & 1,11 \\ 22,34 & 23,13 & 21,73 & 21,76 \\ 1,06 & 1,15 & 1,09 & 1,18 \\ 5,03 & 4,20 & 4,95 & 4,93 \\ 20,27 & 20,3] & 20,29 & 20,30 \\ 0,34 & 0,34 & 0,34 & 0,37 \\ <\mathrm{L} . \mathrm{D} . & <\mathrm{L} . \mathrm{D} . & <\mathrm{L} . \mathrm{D} . & <\mathrm{L} . \mathrm{D} \\ 100,46 & I 00,18 & 99,29 & 100,26\end{array}$

pts/grãol ptбigrãol pt7/grãol pt\&/grãol

$\begin{array}{cccc}I & I & I & I-B \\ 49,01 & 48,17 & 49,31 & 49,05 \\ 0,82 & 0,57 & 0,66 & 0,70 \\ 0,67 & 0,61 & 0,62 & 0,57 \\ 1,10 & 2,73 & 1,29 & 1,63 \\ 21,70 & 20,07 & 21,71 & 22,16 \\ 1,22 & 1,06 & 1,05 & 1,12 \\ 4,94 & 5,09 & 4,88 & 4,36 \\ 20,34 & 20,31 & 20,45 & 20,51 \\ 0,33 & 0,40 & 0,40 & 0,41 \\ <\mathrm{L} . \mathrm{D} . & <\mathrm{L} . \mathrm{D} . & <\mathrm{L} . \mathrm{D} . & <\mathrm{L} . \mathrm{D} . \\ 100,13 & 99,00 & 100,37 & 100,52\end{array}$

Fórmula estrutural com base em 6 oxigênios e 4 cátions

\begin{tabular}{|c|c|c|c|c|c|c|c|c|c|}
\hline $\mathrm{Si}$ & 2,012 & 1,967 & 1,968 & 1,967 & 1,958 & 1,956 & 1,943 & 1,962 & 1,957 \\
\hline $\mathrm{Al}_{\mathrm{IV}}$ & 0,000 & 0,031 & 0,029 & 0,031 & 0,032 & 0,031 & 0,029 & 0,029 & 0,027 \\
\hline $\mathrm{Fe}^{3+}$ & 0,000 & 0,002 & 0,002 & 0,002 & 0,011 & 0,013 & 0,028 & 0,009 & 0,016 \\
\hline SOMA-T & 2,000 & 2,000 & 2,000 & 2,000 & 2,000 & 2,000 & 2,000 & 2,000 & 2,000 \\
\hline $\mathrm{Al}_{\mathrm{VI}}$ & 0,018 & 0,000 & 0,000 & 0,000 & 0,000 & 0,000 & 0,000 & 0,000 & 0,000 \\
\hline $\mathrm{Ti}_{3+}$ & 0,004 & 0,025 & 0,021 & 0,024 & 0,024 & 0,024 & 0,017 & 0,020 & 0,021 \\
\hline $\mathrm{Fe}^{3+}$ & 0,091 & 0,010 & 0,015 & 0,012 & 0,023 & 0,021 & 0,054 & 0,030 & 0,033 \\
\hline $\mathrm{Mg}$ & 0,091 & 0,298 & 0,251 & 0,297 & 0,293 & 0,294 & 0,306 & 0,290 & 0,260 \\
\hline $\mathrm{Fe}^{2+}$ & 0,796 & 0,667 & 0,712 & 0,667 & 0,661 & 0,661 & 0,623 & 0,661 & 0,687 \\
\hline Mn & 0,000 & 0,000 & 0,000 & 0,000 & 0,000 & 0,000 & 0,000 & 0,000 & 0,000 \\
\hline$O M A-M 1$ & 1,000 & 1,000 & 1,000 & 1,000 & 1,000 & 1,000 & 1,000 & 1,000 & 1,000 \\
\hline $\mathbf{M g}$ & 0,000 & 0,000 & 0,000 & 0,000 & 0,000 & 0,000 & 0,000 & 0,000 & 0,000 \\
\hline $\mathrm{Fe} 2$ & 0,037 & 0,075 & 0,063 & 0,062 & 0,064 & 0,063 & 0,055 & 0,061 & 0,053 \\
\hline $\mathrm{Mn}$ & 0,029 & 0,036 & 0,039 & 0,037 & 0,040 & 0,041 & 0,036 & 0,035 & 0,038 \\
\hline $\mathrm{Ca}$ & 0,804 & 0,863 & 0,872 & 0,873 & 0,867 & 0,870 & 0,878 & 0,872 & 0,877 \\
\hline $\mathrm{Na}$ & 0,130 & 0,026 & 0,027 & 0,027 & 0,029 & 0,026 & 0,032 & 0,031 & 0,032 \\
\hline K & 0,001 & 0,000 & 0,000 & 0,001 & 0,000 & 0,000 & 0,000 & 0,000 & 0,000 \\
\hline$O M A-M 2$ & 1,000 & 1,000 & 1,000 & 1,000 & 1,000 & 1,000 & 1,000 & 1,000 & 1,000 \\
\hline$m g \#$ & 0,099 & 0,287 & 0,244 & 0,289 & 0,288 & 0,289 & 0,311 & 0,286 & 0,260 \\
\hline
\end{tabular}

Sienito Verde Grosso

ptl/grão2 pt2/grão2 pt3/grão2 pt4/grão2 pt5/grão2

$\begin{array}{ccccc}N & N-I & N-I & I & I-B \\ 49,10 & 48,60 & 48,62 & 49,04 & 48,14 \\ 0,73 & 0,64 & 0,65 & 0,71 & 0,68 \\ 0,58 & 0,63 & 0,56 & 0,51 & 0,44 \\ 0,99 & 1,73 & 1,81 & 0,50 & 0,74 \\ 21,78 & 21,00 & 22,14 & 25,44 & 25,10 \\ 1,01 & 1,03 & 1,07 & 1,16 & 1,16 \\ 5,05 & 5,00 & 4,30 & 2,99 & 2,44 \\ 20,30 & 20,36 & 20,43 & 20,17 & 20,09 \\ 0,33 & 0,36 & 0,36 & 0,32 & 0,39 \\ <\mathrm{L} . \mathrm{D} . & <\mathrm{L} . \mathrm{D} . & <\mathrm{L} . \mathrm{D} . & <\mathrm{L} . \mathrm{D} . & <\mathrm{L} . \mathrm{D} . \\ 99,88 & 99,35 & 99,93 & 100,85 & 99,17 \\ & & & & \\ 1,962 & 1,953 & 1,954 & 1,971 & 1,973 \\ 0,027 & 0,030 & 0,027 & 0,024 & 0,021 \\ 0,010 & 0,017 & 0,020 & 0,005 & 0,006 \\ 2,000 & 2,000 & 2,000 & 2,000 & 2,000 \\ 0,000 & 0,000 & 0,000 & 0,000 & 0,000 \\ 0,022 & 0,019 & 0,020 & 0,022 & 0,021 \\ 0,019 & 0,035 & 0,035 & 0,011 & 0,016 \\ 0,301 & 0,299 & 0,258 & 0,179 & 0,149 \\ 0,658 & 0,646 & 0,688 & 0,789 & 0,813 \\ 0,000 & 0,000 & 0,000 & 0,000 & 0,000 \\ 1,000 & 1,000 & 1,000 & 1,000 & 1,000 \\ 0,000 & 0,000 & 0,000 & 0,000 & 0,000 \\ 0,070 & 0,060 & 0,056 & 0,067 & 0,047 \\ 0,034 & 0,035 & 0,036 & 0,039 & 0,040 \\ 0,870 & 0,877 & 0,879 & 0,869 & 0,882 \\ 0,025 & 0,028 & 0,028 & 0,025 & 0,031 \\ 0,000 & 0,000 & 0,000 & 0,000 & 0,000 \\ 1,000 & 1,000 & 1,000 & 1,000 & 1,000 \\ 0,292 & 0,298 & 0,257 & 0,173 & 0,148\end{array}$

Obs: 1- $\mathrm{Fe}_{2} \mathrm{O}_{3}$ e FeO calculados pelo método de Droop (1987).

2- $\mathrm{N}$, núcleo; 1 , região intermediária; $\mathrm{B}$, borda; $\mathrm{pt}$, ponto analisado.

3-<L. D.: abaixo do limite de detecção.

4- $\mathrm{mg} \#=\mathrm{Mg} /\left(\mathrm{Mg}+\mathrm{Fe}^{2+}\right)$. 
Tabela Y.2. Continuação

Fácies Sienito Verde Grosso

Amostra

Análise pt6/grão2 pt7/grão2 pt8/grão2

ocalizaçä $\quad B$

$\begin{array}{llcc}\mathrm{SiO}_{2} & 48,82 & B & B \\ \mathrm{IIO}_{2} & 0,16 & 0,16 & 49,46\end{array}$

$\begin{array}{llll}\mathrm{TiO}_{2} & 0,16 & 0,22 & 0,15\end{array}$

$\begin{array}{llll}\mathrm{Al}_{2} \mathbf{O}_{3} & 0,19 & 0,21 & 0,13\end{array}$

$\begin{array}{llll}\mathrm{Fe}_{2} \mathrm{O}_{3} & 3,61 \quad 3,59 & 4,67\end{array}$

$\begin{array}{llll}\mathrm{FeO} & 24,08 \quad 23,98 \quad 22,98\end{array}$

$\begin{array}{llll}\text { MnO } & 1,08 & 1,20 & 0,84\end{array}$

$\begin{array}{llll}\text { MgO } & 1,45 & 1,52 & 1,43\end{array}$

$\begin{array}{llll}\mathrm{CaO} & 18,75 & 18,45 & 18,00\end{array}$

$\begin{array}{llll}\mathrm{Na}_{2} \mathrm{O} & 1,45 & 1,55 & 2,12\end{array}$

$\mathrm{K}_{2} \mathbf{O} \quad<\mathrm{L} . \mathrm{D} . \quad 0,08<\mathrm{L} . \mathrm{D}$.

Total $\quad 99,59 \quad 99,96 \quad 99,79$
Sienito Verde Grosso

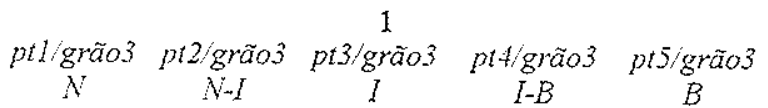

$\begin{array}{cc}N & N-I \\ 49,12 & 48,23\end{array}$

0,12
0,18

2,30

22,99

1,22
2,87

2,87
20,41

0,72

$<$ L. D

99,94

$\begin{array}{ccc}I & I-B & B \\ 49,38 & 48,33 & 48,64 \\ 0,07 & 0,21 & 0,14 \\ 0,24 & 0,10 & 0,09 \\ 1,90 & 4,58 & 4,15 \\ 24,97 & 23,71 & 24,09 \\ 1,18 & 0,90 & 0,95 \\ 1,71 & 1,30 & 1,28 \\ 19,31 & 18,41 & 18,23 \\ 1,11 & 1,61 & 1,64 \\ <\mathrm{L} . \mathrm{D} . & <\mathrm{L} . \mathrm{D} . & <\mathrm{L} . \mathrm{D} . \\ 99,87 & 99,15 & 99,20\end{array}$

grão3
$B$

Fórmula estrutural com base em 6 oxigênios e 4 cátions

\begin{tabular}{|c|c|c|c|c|c|c|c|c|}
\hline $\mathrm{Si}$ & 1,993 & 1,997 & 2,004 & 1,985 & 1,969 & 2,007 & 1,984 & 1,995 \\
\hline $\mathrm{Al}_{\mathrm{IV}}$ & 0,007 & 0,003 & 0,000 & 0,009 & 0,024 & 0,000 & 0,005 & 0,004 \\
\hline $\mathrm{Fe}^{3+}$ & 0,000 & 0,000 & 0,000 & 0,006 & 0,007 & 0,000 & 0,011 & 0,001 \\
\hline$S O M A-T$ & 2,000 & 2,000 & 2,004 & 2,000 & 2,000 & 2,007 & 2,000 & 2,000 \\
\hline $\mathrm{Al}_{\mathrm{VI}}$ & 0,002 & 0,007 & 0,006 & 0,000 & 0,000 & 0,011 & 0,000 & 0,000 \\
\hline $\mathrm{Ti}$ & 0,005 & 0,007 & 0,005 & 0,004 & 0,017 & 0,002 & 0,007 & 0,004 \\
\hline $\mathrm{Fe}^{3+}$ & 0,110 & 0,109 & 0,141 & 0,064 & 0,023 & 0,058 & 0,129 & 0,126 \\
\hline $\mathrm{Mg}$ & 0,088 & 0,092 & 0,086 & 0,173 & 0,172 & 0,104 & 0,080 & 0,078 \\
\hline $\mathrm{Fe}^{2+}$ & 0,795 & 0,786 & 0,762 & 0,760 & 0,788 & 0,825 & 0,785 & 0,792 \\
\hline Mn & 0,000 & 0,000 & 0,000 & 0,000 & 0,000 & 0,000 & 0,000 & 0,000 \\
\hline$O M A-M I$ & 1,000 & 1,000 & 1,000 & 1,000 & 1,000 & 1,000 & 1,000 & 1,000 \\
\hline $\mathrm{Mg}$ & 0,000 & 0,000 & 0,000 & 0,000 & 0,000 & 0,000 & 0,000 & 0,000 \\
\hline $\mathrm{Fe} 2$ & 0,028 & 0,029 & 0,019 & 0,018 & 0,052 & 0,024 & 0,031 & 0,036 \\
\hline $\mathrm{Mn}$ & 0,037 & 0,041 & 0,029 & 0,042 & 0,043 & 0,041 & 0,031 & 0,033 \\
\hline $\mathrm{Ca}$ & 0,820 & 0,803 & 0,782 & 0,884 & 0,878 & 0,841 & 0,810 & 0,801 \\
\hline $\mathrm{Na}$ & 0,115 & 0,122 & 0,166 & 0,056 & 0,027 & 0,087 & 0,128 & 0,130 \\
\hline K & 0,000 & 0,004 & 0,000 & 0,000 & 0,000 & 0,000 & 0,000 & 0,000 \\
\hline$O M A-M 2$ & 1,000 & 1,000 & 0,996 & 1,000 & 1,000 & 0,993 & 1,000 & 1,000 \\
\hline$m g \#$ & 0,097 & 0,102 & 0,100 & 0,182 & 0,170 & 0,109 & 0,089 & 0,086 \\
\hline
\end{tabular}

Obs: 1- $\mathrm{Fe}_{2} \mathrm{O}_{3}$ e FeO calculados pelo método de Droop (1987).

$2-\mathrm{N}$, núcleo; 1 , região intermediária; $\mathrm{B}$, borda; pt, ponto analisado.

3-< L. D.: abaixo do limite de detecção.

4. $\mathrm{mg} \#=\mathrm{Mg} /\left(\mathrm{Mg} \div \mathrm{Fe}^{2+}\right)$

Sienito Verde Grosso

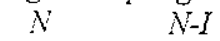

$N-1$
48,45

I

plA/gräo
$I-B$

$T-B$
48,79

47,87

0,48

0,37

0,16

0,10

4,21

25,14

1,11

23,65

0,90

1,60

18,54

1,58

0,37

20,27

20,15

$<$ L. D.

$<$ L. D.

99,52

pt5/grãot pt6/grãot

$B$

$B$

$\quad 49,30$

0,16

0,11

$3,85-4,01$

$24,12 \quad 23,63$

$0,84 \quad 0,79$

$1,47 \quad 1,71$

$100,71 \quad 99,67$

99,70

1,61

$<\mathrm{L}$. D.

18,99

1,56

$<\mathrm{L} . \mathrm{D}$.
100,22

1,971

1,981

1,961

1,991

1906

1,994

0,016

0,018

1,961
0,018
0,021

0,005

0,004

$2,000 \quad 2,000$

0,021
2,000
0,000

2,000

0,000

2,000

2,000

$\begin{array}{llllll}0,015 & 0,019 & 0,015 & 0,005 & 0,005 & 0,003\end{array}$

$\begin{array}{llllll}0,034 & 0,014 & 0,040 & 0,123 & 0,116 & 0,120\end{array}$

$\begin{array}{llllll}0,121 & 0,125 & 0,123 & 0,097 & 0,089 & 0,103\end{array}$

$\begin{array}{llllll}0,829 & 0,842 & 0,822 & 0,775 & 0,787 & 0,773\end{array}$

0,000

1,000

0,000

0,000

0,000

$0,000-0,000-0,000$

1,000

1,000

$0,000 \quad 0,000$

0,044

0,049

0,039

0,033

0,032

0,000

$0,041 \quad 0,037$

0,880

0,035

1,000

0,031

0,039
0,892

0,031

0,029

0,027
0,823

$\begin{array}{llll}0,030 & 0,125 & 0,127 & 0,122\end{array}$

1,000
0,122

1,000

1,000
0,123

0,001
1,000
0,125

0,000

0,000

0,000

$\begin{array}{lll}1,000 & 1,000 & 1,000 \\ 0,107 & 0,098 & 0,114\end{array}$ 
Tabela Y.2. Continuação

Fácies

Amostra

Análise

ocalização

$\mathrm{SiO}_{2}$

$\mathrm{TiO}_{2}$

$\mathrm{Al}_{2} \mathrm{O}_{3}$

$\mathrm{Fe}_{2} \mathrm{O}_{3}$

$\mathrm{FeO}$

$\mathrm{MnO}$

$\mathrm{MgO}$

$\mathrm{CaO}$

$\mathrm{Na}_{2} \mathrm{O}$

$\mathrm{K}_{2} \mathrm{O}$

Total
Sienito Verde Grosso

ptl/grãos pt2/grãos pt3/grãos pt4/grãos pt5/grãos

$\begin{array}{ccccc}N & N-I & I & I-B & B \\ 48,05 & 48,14 & 48,68 & 48,39 & 48,73\end{array}$

0,74

$0,64 \quad 0,62$

1,43

0,48

0,46

0,46
1,53

1,53
23,23

24,47

24,76

1,19

1,13

1,23

23,23
1,20

3,47
20,33

20,33
0,38

<E. D.

$<$ L. D.

99,60

99,73

99.94

xigênios e 4 cátion

$\begin{array}{cccccc}\text { Fórmula estrutural com base em } & \mathbf{6} \text { oxigênios } & \text { e } 4 \text { cations } \\ \mathrm{Si} & 1,959 & 1,958 & 1,975 & 1,962 & 1,977\end{array}$

\begin{tabular}{|c|c|c|c|c|}
\hline & 1,909 & 1,958 & 1,975 & 1,962 \\
\hline $\mathrm{Fe}^{3+}$ & 0,023 & 0,023 & 0,022 & 0,022 \\
\hline & 0,018 & 0,019 & 0,003 & 0,016 \\
\hline SUIVLA-I & 2,000 & 2,000 & 2,000 & 2,000 \\
\hline $\mathrm{Al}_{\mathrm{VI}}$ & 0,000 & 0,000 & 0,000 & 0,000 \\
\hline $\mathrm{Ti}$ & 0,023 & 0,018 & 0,019 & 0,019 \\
\hline $\mathrm{Fe}^{s+}$ & 0,026 & 0,034 & 0,012 & 0,030 \\
\hline $\mathrm{Mg}$ & 0,150 & 0,160 & 0,171 & 0,209 \\
\hline $\mathrm{Fe}^{2+}$ & 0,801 & 0,787 & 0,798 & 0,742 \\
\hline $\mathbf{M n}$ & 0,000 & 0,000 & 0,000 & 0,000 \\
\hline$S O M A-M 1$ & 1,000 & 1,000 & 1,000 & 1,000 \\
\hline $\mathrm{Mg}$ & 0,000 & 0,000 & 0,000 & 0,000 \\
\hline $\mathrm{Fe} 2$ & 0,040 & 0,045 & 0,043 & 0,046 \\
\hline Mn & 0,041 & 0,039 & 0,042 & 0,041 \\
\hline $\mathrm{Ca}$ & 0,888 & 0,887 & 0,889 & 0,883 \\
\hline $\mathrm{Na}$ & 0,031 & 0,028 & 0,026 & 0,030 \\
\hline $\mathbf{K}$ & 0,001 & 0,000 & 0,000 & 0,000 \\
\hline SOMA-M2 & 1,000 & 1,000 & 1,000 & 1,000 \\
\hline$m g \#$ & 0,151 & 0110 & 0,169 & 0.210 \\
\hline
\end{tabular}

$m g$

0,162

0,210

$B$
48,73

0,79

0,11

1,21

2,41
20,14

0,35

$<\mathrm{L}$. D

100,21

Obs: 1- $\mathrm{Fe}_{2} \mathrm{O}_{3}$ e FeO calculados pelo método de Droop (1987).

$2-\mathrm{N}$, núcleo; 1 , região intermediária; $\mathrm{B}$, borda; $\mathrm{p}^{t}$, ponto analisado.

3-<L. D.: abaixo do limite de detecção.

4- $\mathrm{mg} \#=\mathrm{Mg} /\left(\mathrm{Mg}+\mathrm{Fe}^{2+}\right)$

Sienito Róseo Médio

ptligrãol pt2/grãol pt3/grãol pt4/grãol pt5/grãol pt6/grãol pt7/grãol pt8/grãol ptg/grãol

N-I N

49,59

0,57

$0,54 \quad 0,59$

$1,02 \quad 1,14$

22,42

1,04

4,50

20,49

100,61

22,20

4,65

20,48

0,40

$<\mathrm{L}, \mathrm{D}$

100,60

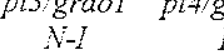

$I \quad I-B \quad I-B$ pt/grä

$\begin{array}{lll}-B & B & B\end{array}$

49,53

$49,48 \quad 49,28$

$1-B$
48,83

48,83
0,58

0,45

$0,51 \quad 0,50$

22,23

1,02

1,43

1,04
4,45

1,07

4,46
20,44

20,49

$<$ I. D

0,41

22,85

2,2

22,15
1,13

4,16

20,42

0,42

100,84

100,60

100,82

207

0,42

$<\mathrm{L} . \mathrm{D}$

100,55

48,25
0,50

0,47$$
2,62
$$

2,62
1,05
3,73

1,05
3,73
20,63

20,63

0,40

99,80

$\begin{array}{cc}B & B \\ 49,30 & 48,60\end{array}$

$0,20 \quad 0,33$

$0,21 \quad 0,23$

$25,49 \quad 24,76$

$\begin{array}{cc}25,49 & 24,76 \\ 1,03 & 1,00\end{array}$

$2,17 \quad 2,39$

$19,87 \quad 20,06$

0,58

$\begin{array}{ll}<\mathrm{L} . \mathrm{D} . & <\mathrm{L} . \mathrm{D} . \\ 100,74 & 100,89\end{array}$

$\begin{array}{lll}1,972 & 1,963 & 1,967 \\ 0,025 & 0,028 & 0,026 \\ 0,003 & 0,009 & 0,007 \\ 2,000 & 2,000 & 2,000 \\ 0,000 & 0,000 & 0,000 \\ 0,017 & 0,022 & 0,016 \\ 0,028 & 0,025 & 0,038 \\ 0,267 & 0,276 & 0,263 \\ 0,688 & 0,678 & 0,683 \\ 0,000 & 0,000 & 0,000 \\ 1,000 & 1,000 & 1,000 \\ 0,000 & 0,000 & 0,000 \\ 0,058 & 0,061 & 0,056 \\ 0,035 & 0,036 & 0,035 \\ 0,873 & 0,873 & 0,872 \\ 0,034 & 0,031 & 0,037 \\ 0,000 & 0,000 & 0,001 \\ 1,000 & 1,000 & 1,000 \\ 0,264 & 0,272 & 0,263\end{array}$

\section{1,970}

1,964

1,954

1,949

1,990

1,962

0,006

0,013

0,021

0,022

0,010

0,011

$2,000 \quad 2,000$

2,000

2,000

0,000

0,027

$0,000 \quad 0,000$

0,000

0,000

0,000

2,000

$0,019 \quad 0,020 \quad 0,017$

0,030

0,043

0,01

0,006

0,010

0,265

0,703

0,701

0,22

0,053

0,062

0,691

0,000
1,000

0,000

0,000

0,709

0,131

0,144
0,784

0,000

0,000

1,000

0,000

0,810

0,000

0,059

0,059

0,041

0,000

$1,000 \quad 1,000$

$0,000 \quad 0,000$

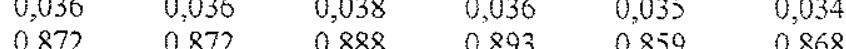

$\begin{array}{llllll}0,872 & 0,872 & 0,888 & 0,893 & 0,859 & 0,868\end{array}$

0,032

0,033

0,033

0,032

0,055

0,00

0,045
0,000

1,000

1,000

1,000

1,000

1,000

1,000
0,147

$0,243 \quad 0.231$

4


Tabela V.2. Continuação

Facies

Amostra

Análise

Análise

calizaç

$\mathrm{SiO}_{2}$

$\mathrm{TiO}_{2}$

$\mathrm{Al}_{2} \mathrm{O}_{3}$

$\mathrm{Fe}_{2} \mathrm{O}_{3}$

$\mathrm{FeO}$

$\mathrm{CaO}$

$\mathrm{K}_{2} \mathrm{O}$

Total
Sienito Róseo Médio

pt1/grão2 pt2/grão2 pt3/grão2 pt4/grão2 pt5/grão2 pt6/grão2 pt/grão2 $N$

$$
\begin{aligned}
& 1 \\
& 49,24
\end{aligned}
$$$$
\stackrel{1}{49,10}
$$$$
1
$$

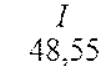

$$
0,73
$$$$
0,59
$$$$
0,66
$$

$$
0,55
$$$$
\begin{aligned}
& 48,55 \\
& 0,58
\end{aligned}
$$$$
\begin{aligned}
& 0,58 \\
& 0,44
\end{aligned}
$$$$
2,60
$$$$
2,00
$$$$
1,48
$$$$
1,69
$$$$
\begin{gathered}
2,57 \\
22,01
\end{gathered}
$$$$
1,07
$$$$
1,19
$$$$
4,13
$$$$
1,07
$$$$
4,49
$$$$
1,09
$$$$
4,32
$$$$
23,22
$$$$
\begin{array}{r}
23,22 \\
1,09 \\
3,40
\end{array}
$$$$
3,40
$$$$
20,48
$$$$
0,42
$$$$
0,40 \quad 0,40
$$$$
\begin{gathered}
20,24 \\
0,41
\end{gathered}
$$

$<\mathrm{L} . \mathrm{D}$.
100,77

<L. D.

0,42

100,61

<L. D.

100.78

$$
\begin{gathered}
I-B \\
49,61 \\
0,64 \\
0,46 \\
1,23 \\
23,72 \\
1,04 \\
3,77 \\
20,61 \\
0,43 \\
<\mathrm{L} . \mathrm{D} .
\end{gathered}
$$

\begin{tabular}{|c|c|c|c|c|c|c|c|}
\hline $\mathrm{Si}$ & 1,952 & 1,964 & 1,958 & 1,950 & 1,949 & 1,968 & 1,977 \\
\hline$A l_{\mathrm{IV}}$ & 0,024 & 0,022 & 0,026 & 0,023 & 0,021 & 0,022 & 0,016 \\
\hline $\mathrm{Fe}^{3+}$ & 0,025 & 0,013 & 0,016 & 0,027 & 0,030 & 0,010 & 0,007 \\
\hline SOMA-T & 2,000 & 2,000 & 2,000 & 2,000 & 2,000 & 2,000 & 2,000 \\
\hline$A l_{Y z}$ & 0,000 & 0,000 & 0,000 & 0,000 & 0,000 & 0,000 & 0,000 \\
\hline $\mathrm{Ti}$ & 0,022 & 0,018 & 0,020 & 0,017 & 0,017 & 0,019 & 0,014 \\
\hline $\mathrm{Fe}^{3+}$ & 0,035 & 0,031 & 0,034 & 0,049 & 0,048 & 0,026 & 0,037 \\
\hline $\mathrm{Mg}$ & 0,252 & 0,246 & 0,267 & 0,257 & 0,203 & 0,223 & 0,165 \\
\hline $\mathrm{Fe}^{2+}$ & 0,690 & 0,705 & 0,679 & 0,678 & 0,731 & 0,731 & 0,784 \\
\hline $\mathrm{Mn}$ & 0,000 & 0,000 & 0,000 & 0,000 & 0,000 & 0,000 & 0,000 \\
\hline$O M A-M I$ & 1,000 & 1,000 & 1,000 & 1,000 & 1,000 & 1,000 & 1,000 \\
\hline $\mathbf{M g}$ & 0,000 & 0,000 & 0,000 & 0,000 & 0,000 & 0,000 & 0,000 \\
\hline $\mathrm{Fe} 2$ & 0,062 & 0,059 & 0,067 & 0,055 & 0,049 & 0,056 & 0,047 \\
\hline Mn & 0,036 & 0,040 & 0,036 & 0,037 & 0,037 & 0,035 & 0,037 \\
\hline $\mathrm{Ca}$ & 0,870 & 0,870 & 0,865 & 0,876 & 0,881 & 0,876 & 0,874 \\
\hline $\mathrm{Na}$ & 0,031 & 0,031 & 0,032 & 0,033 & 0,033 & 0,033 & 0,041 \\
\hline $\mathbf{K}$ & 0,000 & 0,000 & 0,001 & 0,000 & 0,000 & 0,000 & 0,000 \\
\hline$O M A-M 2$ & 1,000 & 1,000 & 1,000 & 1,000 & 1,000 & 1,000 & 1,000 \\
\hline$m g \#$ & 0,251 & 0,243 & 0,264 & 0,259 & 0,207 & 0,221 & 0,165 \\
\hline
\end{tabular}

101,52

$B$
49,13
0,45
0,34
1,48
24,72
1,10
2,75
20,27
0,53
$<$ L. D.
100,76

Fórmula estrutural com base em 6 oxigênios e 4 cátions

Obs: I- $\mathrm{Fe}_{2} \mathrm{O}_{3}$ e $\mathrm{FeO}$ calculados pelo método de Droop (1987)

2- N, núcleo; 1 , região intermediária; $B$, borda; pt, ponto analisado.

3-<L. D.: abaixo do limite de detecção.

$4-\mathrm{mg} \#=\mathrm{Mg} /\left(\mathrm{Mg}+\mathrm{Fe}^{2+}\right)$.
Sienito Verde Grosso

$\begin{array}{ccccccc}p t I & p t 2 & p t 3 & 50 A & p t 5 & p t 6 & p t 7 \\ N & N & N-1 & B & N-I & I & I \\ 49,73 & 49,87 & 49,65 & 50,10 & 50,16 & 49,41 & 49,76 \\ 0,78 & 0,50 & 0,58 & 0,64 & 0,62 & 0,69 & 0,81 \\ 0,68 & 0,57 & 0,59 & 0,67 & 0,69 & 0,63 & 0,76 \\ 1,69 & 1,33 & 1,44 & 1,51 & 1,08 & 2,50 & 1,27 \\ 17,85 & 19,55 & 19,10 & 18,13 & 18,36 & 17,89 & 17,82 \\ 0,96 & 1,02 & 0,96 & 0,99 & 1,05 & 0,90 & 0,94 \\ 7,56 & 6,63 & 6,60 & 7,44 & 7,39 & 6,97 & 7,49 \\ 20,29 & 20,23 & 20,50 & 20,37 & 20,40 & 20,54 & 20,43 \\ 0,40 & 0,38 & 0,38 & 0,43 & 0,39 & 0,46 & 0,42 \\ <\mathrm{L} . \mathrm{D} . & <\mathrm{L} . \mathrm{D} . & <\mathrm{L} . \mathrm{D} . & <\mathrm{L} . \mathrm{D} . & <\mathrm{L} . \mathrm{D} . & <\mathrm{L} . \mathrm{D} . & <\mathrm{L} . \mathrm{D} . \\ 99,94 & 100,07 & 99,81 & 100,28 & 100,13 & 100,00 & 99,69 \\ & & & & & & \\ 1,952 & 1,967 & 1,962 & 1,960 & 1,965 & 1,946 & 1,955 \\ 0,031 & 0,027 & 0,028 & 0,031 & 0,032 & 0,029 & 0,035 \\ 0,017 & 0,007 & 0,010 & 0,009 & 0,004 & 0,025 & 0,009 \\ 2,000 & 2,000 & 2,000 & 2,000 & 2,000 & 2,000 & 2,000 \\ 0,000 & 0,000 & 0,000 & 0,000 & 0,000 & 0,000 & 0,000 \\ 0,023 & 0,015 & 0,017 & 0,019 & 0,018 & 0,020 & 0,024 \\ 0,033 & 0,033 & 0,033 & 0,035 & 0,028 & 0,048 & 0,028 \\ 0,442 & 0,390 & 0,389 & 0,434 & 0,432 & 0,409 & 0,439 \\ 0,502 & 0,563 & 0,561 & 0,512 & 0,522 & 0,522 & 0,509 \\ 0,000 & 0,000 & 0,000 & 0,000 & 0,000 & 0,000 & 0,000 \\ 1,000 & 1,000 & 1,000 & 1,000 & 1,000 & 1,000 & 1,000 \\ 0,000 & 0,000 & 0,000 & 0,000 & 0,000 & 0,000 & 0,000 \\ 0,084 & 0,082 & 0,070 & 0,081 & 0,079 & 0,068 & 0,077 \\ 0,032 & 0,034 & 0,032 & 0,033 & 0,035 & 0,030 & 0,031 \\ 0,853 & 0,855 & 0,868 & 0,854 & 0,856 & 0,867 & 0,860 \\ 0,031 & 0,029 & 0,029 & 0,032 & 0,029 & 0,035 & 0,032 \\ 0,000 & 0,000 & 0,000 & 0,000 & 0,000 & 0,000 & 0,000 \\ 1,900 & 1,000 & 1,000 & 1,000 & 1,000 & 1,000 & 1,000 \\ 0,430 & 0,377 & 0,381 & 0,423 & 0,418 & 0,410 & 0,428\end{array}$


Tabela V.2. Continuação

Fácies

Amostra

Analise

calização

$\mathrm{SiO}_{2}$

$\mathrm{TiO}_{2}$

$\mathrm{Al}_{2} \mathrm{O}_{3}$

$\mathrm{Fe}_{2} \mathrm{O}_{3}$

no

$\mathrm{MgO}$

$\mathrm{CaO}$

$\mathrm{K} \mathrm{O}$

Total pt8

$$
\begin{gathered}
1-B \\
50,40 \\
0.64
\end{gathered}
$$

50,40
0,64

0,76
1,52

17,38

0,91

8,18

20,42

$<\mathrm{L}, \mathrm{D}$

100,59$$
\begin{aligned}
& p+1 \\
& N-1
\end{aligned}
$$$$
0,47
$$$$
<\text { I. D }
$$

24,14

$$
1,10
$$$$
3,47
$$$$
20,08
$$$$
0,42
$$

$<$ L. D

99,71
Sienito Verde Médio

5

$p t 2$
$N$
48,57
0,65
0,53
1,08
22,98
1,10
3,81
20,17
0,42
$<$ L.D.
99,30

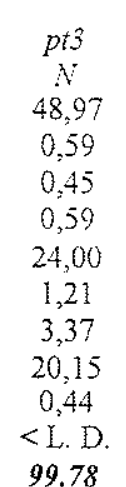

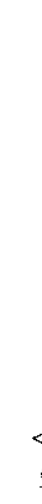

\begin{tabular}{|c|c|c|c|c|c|c|c|c|c|c|c|c|c|c|}
\hline \\
\hline $\mathbf{S i}$ & 1,956 & 1,995 & 1,968 & 1,979 & 1,978 & 1,994 & 1,991 & 1,980 & 1,983 & 1,985 & 1,974 & 1,983 & 1,976 & 1,977 \\
\hline $\mathrm{Al}_{\mathrm{rV}}$ & 0,035 & 0,005 & 0,025 & 0,021 & 0,019 & 0,006 & 0,009 & 0,020 & 0,017 & 0,015 & 0,020 & 0,017 & 0,020 & 0,020 \\
\hline $\mathrm{Fe}^{3+}$ & 0,009 & 0,000 & 0,007 & 0,000 & 0,004 & 0,000 & 0,000 & 0,000 & 0,000 & 0,000 & 0,006 & 0,000 & 0,004 & 0,002 \\
\hline$S O M A-T$ & 2,000 & 2,000 & 2,000 & 2,000 & 2,000 & 2,000 & 2,000 & 2,000 & 2,000 & 2,000 & 2,000 & 2,000 & 2,000 & 2,000 \\
\hline$A l_{\mathrm{VI}}$ & 0,000 & 0,018 & 0,000 & 0,001 & 0,000 & 0,011 & 0,005 & 0,003 & 0,001 & 0,010 & 0,000 & 0,003 & 0,000 & 0,000 \\
\hline $\mathrm{Ti}_{3+}$ & 0,019 & 0,019 & 0,020 & 0,018 & 0,017 & 0,013 & 0,012 & 0,021 & 0,015 & 0,010 & 0,012 & 0,013 & 0,014 & 0,011 \\
\hline $\mathrm{Fe}^{3+}$ & 0,035 & 0,000 & 0,026 & 0,018 & 0,022 & 0,003 & 0,022 & 0,009 & 0,025 & 0,028 & 0,039 & 0,028 & 0,042 & 0,063 \\
\hline $\mathrm{Mg}$ & 0,473 & 0,209 & 0,230 & 0,203 & 0,143 & 0,139 & 0,107 & 0,228 & 0,139 & 0,399 & 0,277 & 0,308 & 0,316 & 0,288 \\
\hline $\mathrm{Fe}^{2+}$ & 0,473 & 0,755 & 0,725 & 0,760 & 0,819 & 0,833 & 0,854 & 0,739 & 0,820 & 0,553 & 0,672 & 0,648 & 0,628 & 0,638 \\
\hline Mn & 0,000 & 0,000 & 0,000 & 0,000 & 0,000 & 0,000 & 0,000 & 0,000 & 0,000 & 0,000 & 0,000 & 0,000 & 0,000 & 0,000 \\
\hline$S O M A-M I$ & 1,000 & 1,000 & 1,000 & 1,000 & 1,000 & 1,000 & 1,000 & 1,000 & 1,000 & 1,000 & 1,000 & 1,000 & 1,000 & 1,000 \\
\hline Mg & 0,000 & 0,000 & 0,000 & 0,000 & 0,000 & 0,000 & 0,000 & 0,000 & 0,000 & 0,000 & 0,000 & 0,000 & 0,000 & 0,000 \\
\hline $\mathrm{Fe} 2$ & 0,092 & 0,061 & 0,054 & 0,051 & 0,054 & 0,048 & 0,052 & 0,062 & 0,040 & 0,079 & 0,058 & 0,072 & 0,064 & 0,049 \\
\hline $\mathrm{Mn}$ & 0,030 & 0,038 & 0,038 & 0,041 & 0,038 & 0,040 & 0,040 & 0,035 & 0,042 & 0,029 & 0,032 & 0,032 & 0,032 & 0,030 \\
\hline $\mathrm{Ca}$ & 0,849 & 0,869 & 0,875 & 0,873 & 0,875 & 0,877 & 0,866 & 0,871 & 0,879 & 0,850 & 0,873 & 0,857 & 0,858 & 0,858 \\
\hline $\mathrm{Na}$ & 0,029 & 0,033 & 0,033 & 0,034 & 0,033 & 0,035 & 0,042 & 0,033 & 0,039 & 0,043 & 0,037 & 0,039 & 0,045 & 0,062 \\
\hline K & 0,000 & 0,000 & 0,000 & 0,000 & 0,000 & 0,000 & 0,000 & 0,000 & 0,000 & 0,000 & 0,000 & 0,000 & 0,001 & 0,001 \\
\hline$S O M A-M 2$ & 1,000 & 1,000 & 1,000 & 1,000 & 1,000 & 1,000 & 1,000 & 1,000 & 1,000 & 1,000 & 1,000 & 1,000 & 1,000 & 1,000 \\
\hline$m g \#$ & 0,456 & 0,204 & 0,228 & 0,200 & 0,140 & 0,137 & 0,106 & 0,222 & 0,139 & 0,387 & 0,275 & 0,300 & 0,313 & 0,295 \\
\hline
\end{tabular}

Fórmula estrutural com base em 6 oxigênios e 4 cátions

Obs: 1- $\mathrm{Fe}_{2} \mathrm{O}_{3}$ e FeO calculados pelo método de Droop (1987).

2- N, núcleo; $I$, região intermediária; $B$, borda; pt ponto analisado. 3-< L. D.: abaixo do limite de deteccão.

4- $\mathrm{mg} \#=\mathrm{Mg} /\left(\mathrm{Mg}+\mathrm{Fe}^{2+}\right)$.

Sienito Róseo Médio

$$
38
$$

$\begin{array}{ccccc}\text { ptl/grãol } & \text { pt2/grãol } & \text { pt3/grãol } & \text { pt4/grãol } & \text { pt5/grãol } \\ N & N-I & I & I-B & B \\ 50,79 & 49,21 & 49,95 & 49,86 & 49,69 \\ 0,33 & 0,38 & 0,44 & 0,48 & 0,36 \\ 0,54 & 0,41 & 0,43 & 0,43 & 0,43 \\ 0,94 & 1,49 & 0,93 & 1,54 & 2,19 \\ 19,32 & 21,77 & 21,67 & 20,88 & 20,05 \\ 0,87 & 0,95 & 0,94 & 0,96 & 0,89 \\ 6,85 & 4,63 & 5,21 & 5,35 & 4,85 \\ 20,29 & 20,30 & 20,15 & 20,21 & 20,13 \\ 0,57 & 0,47 & 0,51 & 0,59 & 0,80 \\ <\mathrm{L} . \mathrm{D} . & <\mathrm{L} . \mathrm{D} . & <\mathrm{L} . \mathrm{D} . & <\mathrm{L} . \mathrm{D} . & <\mathrm{L} . \mathrm{D} \\ 100,51 & 99,62 & 100,24 & 100,31 & 100,01 \\ & & & & \\ 1,985 & 1,974 & 1,983 & 1,976 & 1,977 \\ 0,015 & 0,020 & 0,017 & 0,020 & 0,020 \\ 0,000 & 0,006 & 0,000 & 0,004 & 0,002 \\ 2,000 & 2,000 & 2,000 & 2,000 & 2,000 \\ 0,010 & 0,000 & 0,003 & 0,000 & 0,000 \\ 0,010 & 0,012 & 0,013 & 0,014 & 0,011 \\ 0,028 & 0,039 & 0,028 & 0,042 & 0,063 \\ 0,399 & 0,277 & 0,308 & 0,316 & 0,288 \\ 0,553 & 0,672 & 0,648 & 0,628 & 0,638 \\ 0,000 & 0,000 & 0,000 & 0,000 & 0,000 \\ 1,000 & 1,000 & 1,000 & 1,000 & 1,000 \\ 0,000 & 0,000 & 0,000 & 0,000 & 0,000 \\ 0,079 & 0,058 & 0,072 & 0,064 & 0,049 \\ 0,029 & 0,032 & 0,032 & 0,032 & 0,030 \\ 0,850 & 0,873 & 0,857 & 0,858 & 0,858 \\ 0,043 & 0,037 & 0,039 & 0,045 & 0,062 \\ 0,000 & 0,000 & 0,000 & 0,001 & 0,001 \\ 1,000 & 1,000 & 1,000 & 1,000 & 1,000 \\ 0,387 & 0,275 & 0,300 & 0,313 & 0,295\end{array}$


Tabela V.2. Continuação

\begin{tabular}{|c|c|c|c|c|c|c|}
\hline Fácies & \multicolumn{6}{|c|}{ Sienito Róseo Médio } \\
\hline & & & & 38 & & \\
\hline $\begin{array}{l}\text { Análise } \\
\text { ocalizacão }\end{array}$ & $\begin{array}{c}\text { ptl/grão2 } \\
B\end{array}$ & $\operatorname{pt2}_{I}^{\text {grãoz }}$ & pt3 $\underset{y}{\operatorname{grano} 2}$ & $\underset{I}{p t+g r a ̈ o 2}$ & ${ }_{B}^{p t J / g r a ̆ o 2}$ & pt6/grão2 \\
\hline $\mathrm{SiO}_{2}$ & 51,01 & 50,86 & 50,61 & 50,46 & 48,43 & $\begin{array}{c}D \\
50,15\end{array}$ \\
\hline $\mathrm{TiO}_{2}$ & 0,58 & 0,42 & 0,66 & 0,59 & 0,48 & 0,27 \\
\hline $\mathrm{Al}_{2} \mathrm{O}_{3}$ & 0,71 & 0,84 & 1,12 & 0,69 & 2,79 & 0,38 \\
\hline $\mathrm{Fe}_{2} \mathrm{O}_{3}$ & 0,10 & 1,11 & 2,45 & 0,32 & 1,56 & 1,83 \\
\hline $\mathrm{FeO}$ & 18,86 & 17,61 & 15,19 & 18,73 & 16,85 & 20,08 \\
\hline MnO & 0,88 & 0,91 & 0,89 & 0,91 & 0,88 & 0,99 \\
\hline $\mathrm{MgO}$ & 7,83 & 8,37 & 8,90 & 8,05 & 7,67 & 6,10 \\
\hline $\mathrm{CaO}$ & 19,93 & 19,86 & 19,73 & 19,65 & 19,65 & 20,45 \\
\hline $\mathrm{Na}_{2} \mathrm{O}$ & 0,49 & 0,47 & 0,84 & 0,36 & 0,37 & 0,44 \\
\hline $\mathrm{K}_{2} \mathbf{O}$ & <L. D. & $<$ L. D. & $<$ L. D. & $<\mathrm{L} . \mathrm{D}$. & $<$ L. D. & <L. D. \\
\hline Total & 100,39 & 100,50 & 100,38 & 99,78 & 98,68 & 100,68 \\
\hline
\end{tabular}

Fórmula estrutural com base em 6 oxigênios e 4 cátions

\begin{tabular}{|c|c|c|c|c|c|c|c|c|c|}
\hline \\
\hline $\mathrm{Si}$ & 1,984 & 1,971 & 1,951 & 1,976 & 1,912 & 1,973 & 1,981 & 1,997 & 1,995 \\
\hline $\mathrm{Al}_{\mathrm{IV}}$ & 0,016 & 0,029 & 0,049 & 0,024 & 0,088 & 0,017 & 0,019 & 0,003 & 0,005 \\
\hline $\mathrm{Fe}^{3+}$ & 0,000 & 0,000 & 0,000 & 0,000 & 0,000 & 0,010 & 0,000 & 0,000 & 0,000 \\
\hline$S O M A-T$ & 2,000 & 2,000 & 2,000 & 2,000 & 2,000 & 2,000 & 2,000 & 2,000 & 2,000 \\
\hline $\mathrm{Al}_{\mathrm{VI}}$ & 0,017 & 0,009 & 0,002 & 0,008 & 0,042 & 0,000 & 0,002 & 0,007 & 0,004 \\
\hline $\mathrm{Ti}$ & 0,017 & 0,012 & 0,019 & 0,018 & 0,014 & 0,008 & 0,016 & 0,011 & 0,007 \\
\hline $\mathrm{Fe}^{3+}$ & 0,003 & 0,033 & 0,071 & 0,009 & 0,046 & 0,045 & 0,016 & 0,322 & 0,218 \\
\hline $\mathrm{Mg}$ & 0,454 & 0,484 & 0,511 & 0,470 & 0,452 & 0,358 & 0,183 & 0,043 & 0,073 \\
\hline $\mathrm{Fe}^{z+}$ & 0,510 & 0,462 & 0,397 & 0,496 & 0,446 & 0,590 & 0,783 & 0,610 & 0,698 \\
\hline $\mathrm{Mn}$ & 0,000 & 0,000 & 0,000 & 0,000 & 0,000 & 0,000 & 0,000 & 0,007 & 0,000 \\
\hline SOMAA-M1 & 1,000 & 1,000 & 1,000 & 1,000 & 1,000 & 1,000 & 1,000 & 1,000 & 1,000 \\
\hline Mg & 0,000 & 0,000 & 0,000 & 0,000 & 0,000 & 0,000 & 0,000 & 0,000 & 0,000 \\
\hline $\mathrm{Fe} 2$ & 0,103 & 0,109 & 0,093 & 0,118 & 0,110 & 0,071 & 0,066 & 0,000 & 0,003 \\
\hline Mn & 0,029 & 0,030 & 0,029 & 0,030 & 0,029 & 0,033 & 0,035 & 0,021 & 0,032 \\
\hline $\mathrm{Ca}$ & 0,831 & 0,824 & 0,815 & 0,824 & 0,831 & 0,862 & 0,867 & 0,622 & 0,730 \\
\hline $\mathrm{Na}$ & 0,037 & 0,035 & 0,063 & 0,027 & 0,029 & 0,034 & 0,031 & 0,357 & 0,234 \\
\hline $\mathbf{K}$ & 0,000 & 0,002 & 0,000 & 0,001 & 0,000 & 0,000 & 0,000 & 0,000 & 0,000 \\
\hline$S O M A-M 2$ & 1,000 & 1,000 & 1,000 & 1,000 & 1,000 & 1,000 & 1,000 & 1,000 & 1,000 \\
\hline$m g \#$ & 0,425 & 0,459 & 0,511 & 0,434 & 0,448 & 0,351 & 0,177 & 0,066 & 0,094 \\
\hline
\end{tabular}

\begin{tabular}{|c|c|c|}
\hline \multicolumn{3}{|c|}{$\begin{array}{c}\text { Sienito Verde Grosso } \\
3 \mathrm{D}\end{array}$} \\
\hline $\mathrm{pt}$ & $p t^{2}$ & pt3 \\
\hline$N$ & $B$ & $B$ \\
\hline 48,70 & 50,00 & 49,73 \\
\hline 0,53 & 0,35 & 0,24 \\
\hline 0,43 & 0,21 & 0.19 \\
\hline 2,55 & 2,80 & 2,75 \\
\hline 22,89 & 25,12 & 24,67 \\
\hline 1,03 & 0,82 & 0,94 \\
\hline 3,02 & 0,72 & 1,22 \\
\hline 19,90 & 14,53 & 16,99 \\
\hline 0,39 & 4,61 & 3,01 \\
\hline <L. D. & $<$ L. D. & $<$ L. D. \\
\hline 99,44 & 99,16 & 99,75 \\
\hline 1,981 & 1,997 & 1,995 \\
\hline 0,019 & 0,003 & 0,005 \\
\hline 0,000 & 0,000 & 0,000 \\
\hline 2,000 & 2,000 & 2,000 \\
\hline 0,002 & 0,007 & 0,004 \\
\hline 0,016 & 0,011 & 0,007 \\
\hline 0,016 & 0,322 & 0,218 \\
\hline 0,183 & 0,043 & 0,073 \\
\hline 0,783 & 0,610 & 0,698 \\
\hline 0,000 & 0,007 & 0,000 \\
\hline 1,000 & 1,000 & 1,000 \\
\hline 0,000 & 0,000 & 0,000 \\
\hline 0,066 & 0,000 & 0,003 \\
\hline 0,035 & 0,021 & 0,032 \\
\hline 0,867 & 0,622 & 0,730 \\
\hline 0,031 & 0,357 & 0,234 \\
\hline 0,000 & 0,000 & 0,000 \\
\hline 1,000 & 1,000 & 1,000 \\
\hline 0,177 & 0,066 & 0,094 \\
\hline
\end{tabular}

Obs: 1- $\mathrm{Fe}_{2} \mathrm{O}_{3}$ e FeO calculados pelo método de Droop (1987)

$2-\mathrm{N}$, núcleo; $I$, região intermediária; $B$, borda; $p t$, ponto anailisado.

$3<$ L. D.: abaixo do limite de deteccão.

4- $\mathrm{mg} \#=\mathrm{Mg} /\left(\mathrm{Mg}+\mathrm{Fe}^{2+}\right)$. 


\begin{tabular}{|c|c|c|c|c|c|c|c|c|c|c|c|c|c|c|}
\hline \multirow{2}{*}{$\begin{array}{l}\text { Fácies } \\
\text { Amostra } \\
\text { Análise }\end{array}$} & \multicolumn{5}{|c|}{$\begin{array}{l}\text { Diorito } \\
\text { s0B }\end{array}$} & \multirow{2}{*}{\multicolumn{6}{|c|}{$\begin{array}{l}\text { Rocha Hibrida } \\
\quad\{\mathrm{D}\end{array}$}} & \multicolumn{3}{|c|}{$\begin{array}{c}\text { Roch Hibrida } \\
34 \mathrm{~B}\end{array}$} \\
\hline & $p+3$ & $p i t$ & $p i s$ & pto & $p^{t} t^{7}$ & & & & & & $p t^{s}$ & $p t 1$ & & \\
\hline Localizaçấo & $\begin{array}{ll}7.5 \\
4080\end{array}$ & $N$ & $i$ & $I$ & $B$ & $I$ & $I$ & $i$ & $x$ & I & $B$ & N-I & $N_{1-1}$ & $\frac{p t s}{N}$ \\
\hline $\mathrm{SiO}_{2}$ & 49,89 & 50,11 & $50,6 ?$ & 50.98 & 50.97 & 47,34 & 46,67 & 50,58 & 49.56 & 50,38 & 5,37 & 46,14 & 45,38 & 44.28 \\
\hline $\mathrm{TiO}_{2}$ & 0,93 & 0,88 & 0,71 & 0.87 & 0,90 & 0,94 & 0,95 & 0.50 & 0.51 & 0,40 & 0,10 & 1,06 & 1.24 & 1.40 \\
\hline $\mathrm{Al}_{2} \mathrm{O}_{3}$ & 3,80 & 3.83 & 3,58 & 3,82 & 3,74 & 5,21 & 5,86 & 2.84 & 2.84 & 2,78 & 0,75 & 3,66 & 3,70 & 6,27 \\
\hline $\mathrm{Fe}_{2} \mathrm{O}_{3}$ & 2,77 & 2.52 & 5,00 & 5,27 & 4,19 & 5,91 & $8,6 !$ & 4,16 & 0,77 & 3,32 & 0,39 & $\angle \mathrm{L} . \mathrm{D}$. & 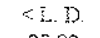 & 4,86 \\
\hline $\mathrm{FeO}$ & 12,15 & 12,86 & 9,87 & $\begin{array}{l}9,65 \\
0,24\end{array}$ & $\begin{array}{l}10,78 \\
0,22\end{array}$ & & $\begin{array}{l}14,96 \\
0.25\end{array}$ & $\begin{array}{l}17.57 \\
0.26\end{array}$ & 21,06 & 19,35 & 32,09 & 26,29 & 27.83 & 18,84 \\
\hline $\mathrm{MnO}$ & $\begin{array}{l}0.25 \\
14.90\end{array}$ & $\begin{array}{l}0.28 \\
14,82\end{array}$ & $\begin{array}{r}0,21 \\
15,01\end{array}$ & $\begin{array}{l}0,24 \\
15,08\end{array}$ & 15.25 & $\begin{array}{l}0,25 \\
0,26\end{array}$ & 8,84 & & 0.25 & 0,32 & 0.75 & $0,9\}$ & 094 & 0.8 \\
\hline $\begin{array}{l}\mathrm{MgO} \\
\mathrm{CaO}\end{array}$ & 11,03 & 11,04 & $\begin{array}{l}15,01 \\
11,03\end{array}$ & 11,09 & 1104 & 1009 & $0,0.4$ & 30,65 & $10 \%$ & 10,59 & 10.92 & 6,39 & 514 & 7,45 \\
\hline $\mathrm{Na}_{2} \mathrm{O}$ & 0,70 & $0.8:$ & 0,82 & 0.76 & 0,75 & $\begin{array}{l}10,99 \\
1,08\end{array}$ & 10,36 & $10,9:$ & 10,72 & 10,39 & 1,43 & 9,04 & 8.64 & 9,80 \\
\hline $\mathrm{K}_{1} \mathrm{O}$ & 0,23 & 0.24 & 0,22 & 0,24 & 0,22 & $\begin{array}{l}1,08 \\
0,46\end{array}$ & 1,26 & 0,69 & 0,67 & 0,72 & 0,23 & 2,44 & 2,38 & 2,68 \\
\hline $\mathrm{ZnO}$ & CL. D. & 0.07 & 0,0 & 0,27 & $0,0 \mathrm{i}$ & $\begin{array}{l}0,46 \\
0.15\end{array}$ & 0,54 & 0,21 & 0.24 & 0,19 & CD. D. & $0, \%$ & $08\}$ & 0,76 \\
\hline $\mathrm{ZrO}_{2}$ & $\angle \mathrm{D}, \mathrm{D}$. & $<\tilde{L}, \mathrm{D}$. & $<$ L. D. & $\angle I . D$. & $<\mathrm{L} . \mathrm{D}$. & 0.15 & 0,15 & 0.27 & 0.28 & 0,20 & 0,14 & 1,32 & 0.98 & 1,60 \\
\hline$F$ & 0,06 & $<\mathrm{L} . \mathrm{D}$. & $<L . D$. & $\angle D$ D. & $\because$ L D & 0,11 & 0.13 & 0.0 & 0,67 & 0.07 & CD. & 0,15 & 0.11 & 0.13 \\
\hline $\mathrm{Cl}$ & $<\bar{L} . \mathrm{D}$. & $\angle I . D$. & $\angle \mathrm{D} D$. & CD. & CED. & $\begin{array}{l}<L . D \text {. } \\
<L . D \text {. }\end{array}$ & $\begin{array}{l}<E . D . \\
<L . D .\end{array}$ & D. D & 09 & $\mathrm{LD}$ & $\triangle \mathrm{L} D$ & 0.08 & 1. & 0,12 \\
\hline Parcia] & 96,71 & 97,51 & 97,33 & 98,28 & 98,04 & 98,54 & 98,61 & 98,79 & <i. & I.D. & $\because L_{L}$ D. & $<\mathrm{L} . \mathrm{D}$. & $\mathrm{L}, \mathrm{D}$ & L. D. \\
\hline $\mathrm{O}_{-} \mathrm{F}_{-} \mathrm{Cl}$ & 0,00 & 0.02 & 0,01 & 0.00 & 0.00 & 0,02 & 0,01 & 0,00 & $\begin{array}{l}97,85 \\
0.04\end{array}$ & 98,69 & 98,26 & 98,27 & 97,19 & 98,96 \\
\hline Total & 96,71 & 97,49 & 97.32 & 98,28 & 98.04 & 98,83 & 98,60 & 98,78 & $\begin{array}{l}0,64 \\
97,81\end{array}$ & 0,00 & 0,01 & 0.04 & 0.02 & 0,05 \\
\hline \multirow{2}{*}{\multicolumn{15}{|c|}{ Fórmula estrutural* }} \\
\hline & & & & & & & & & & & & & & \\
\hline $\mathbf{A}^{\mathrm{IV}}$ & 0,659 & , 3391 & .369 &, 352 & $\therefore 662$ & .082 & 6,969 & 5,504 & 7.493 & 7,512 & 7,855 & 7,254 & .258 & 6,856 \\
\hline Soma-T $T$ & 8.000 & $\begin{array}{l}0,65 ! \\
8,000\end{array}$ & $0,63 !$ & 0,648 & 0,638 & 0,918 & 1,031 & 0,496 & 0.507 & 0,488 & 0,135 & 0,678 & $0.69=$ & 1.144 \\
\hline$A \mathbf{I}^{\mathrm{VI}}$ & 0,000 & $\begin{array}{l}8,000 \\
0,000\end{array}$ & $\begin{array}{r}8,000 \\
0,000\end{array}$ & $\begin{array}{l}8,000 \\
0,000\end{array}$ & $\begin{array}{l}8,000 \\
0,000\end{array}$ & $\begin{array}{l}8,000 \\
0,000\end{array}$ & $\begin{array}{l}8,000 \\
0,000\end{array}$ & 8,000 & 8,000 & $\begin{array}{l}8,000 \\
0,000\end{array}$ & 8,000 & $\begin{array}{l}7,932 \\
0,006\end{array}$ & $\begin{array}{l}7,955 \\
0.509\end{array}$ & 8.000 \\
\hline $\mathrm{xi}$ & 0,103 & 0,095 & 0,078 & 0,095 & 0.097 & $0: 05$ & 0,107 & 0,056 & 0.058 & 0.045 & 0,011 & 0,000 & 0,060 & $0,00 \%$ \\
\hline $\mathrm{Zr}_{\mathrm{r}}$ & 0,000 & 0,000 & 0,000 & 0000 & 0000 & 0,008 & 0,010 & 0.006 & 0,005 & 0,005 & 0,000 & 0,012 & 2199 & 0,162 \\
\hline $\mathrm{Fe}^{3+}$ & 0,321 & 0,269 & 0,534 & 0512 & 0,454 & 0,74 & 1,081 & 0,400 & 0.045 & 0,323 & 0.020 & 0,012 & 0009 & $0.01 \%$ \\
\hline $\mathrm{Mg}$ & 3,268 & 3,235 & 3,254 & 3,242 & 3,276 & 2.051 & 1,968 & 2,354 & $\begin{array}{r}.045 \\
2.432\end{array}$ & 2,355 & 2492 & 0,000 & 0,000 & 0.227 \\
\hline $\mathrm{Zn}$ & 0,000 & 0,008 & 0,008 & 0,029 & 0001 & 0,021 & & & 2.432 & & 2,492 & 1,497 & 1,225 & 1.720 \\
\hline $\mathrm{Fe}^{1-}$ & 1.397 & 1,390 & 1,125 & 1,122 & 1,11 & 2,057 & $12 \div 4$ & 0.029 & 0,032 & 0.022 & 0,015 & 0,153 & 6.115 & 0.182 \\
\hline Min & 0,000 & 0,000 & 0,000 & 0,000 & 0000 & 0,018 & $\begin{array}{l}1,734 \\
0,122\end{array}$ & 2,154 & 2,428 & 2,251 & 2,459 & 3,214 & 3,502 & 2,698 \\
\hline Soma-C & 5,000 & 5,000 & 5,000 & 5,000 & 5,000 & 5,000 & 0,032 & 0,000 & 0,000 & 0,000 & 0,000 & 0,000 & 0,000 & 0,000 \\
\hline $\mathrm{Mg}$ & 0.000 & 0,000 & 0,000 & 0,000 & 0,000 & 0,000 & $\begin{array}{l}7,968 \\
0,000\end{array}$ & $\begin{array}{l}5,000 \\
0,000\end{array}$ & 5,000 & 5,000 & 5,000 & 5,000 & 5,000 & 5,000 \\
\hline $\mathrm{zn}$ & 0,000 & 0,000 & 1,000 & 0,000 & 0,000 & 0,000 & 0.000 & 0.000 & 0,000 & $\begin{array}{l}0,000 \\
0,000\end{array}$ & $\begin{array}{l}0,000 \\
0,000\end{array}$ & $\begin{array}{l}0,000 \\
0,000\end{array}$ & 000 & 0,000 \\
\hline $\mathrm{Fe}^{2+}$ & 0,174 & 0,194 & 0,089 & 0,102 & 0132 & 0,000 & 0,000 & 0.000 & 0,278 & 0,213 & 1,675 & 0,243 & 0220 & 9,000 \\
\hline Mn & 0.031 & 0,034 & 0,025 & 0,029 & 0.027 & 0,014 & 9000 & 0,033 & 0032 & 0,040 & 0,097 & 0,121 & 0128 & 0,081 \\
\hline $\mathrm{Ca}$ & 1,739 & 1,732 & 1,719 & 1,713 & 1.78 & 1,761 & 1,657 & 1,744 & $1,73 ?$ & 1,660 & 0,234 & 1,523 & 48 & 0,02 \\
\hline $\mathrm{Na}$ & 0,057 & 0,039 & 0,16 & 0,156 & 0.132 & 0,225 & 0,343 & 0133 & 0,000 & 0.050 & 0,000 & 0,113 & 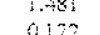 & 1,626 \\
\hline Soma-B & 2,000 & 2,000 & 2,000 & 2.000 & 2,000 & 2.000 & 2,000 & 2,000 & $2.0 \div 7$ & & & , & 0172 & 0191 \\
\hline $\mathrm{Na}$ & 0,142 & 0,191 & 0,065 & 0,057 & 0,079 & 0,088 & 0,022 & 0,066 & 0195 & 0,119 & 0,068 & 0,631 & $\begin{array}{l}2,000 \\
0,557\end{array}$ & 2,000 \\
\hline K & 0,044 & 0,044 & 0,040 & 0,044 & $0,0 \% 0$ & 0,088 & 0,102 & 0,039 & 0,046 & 0,036 & 0,000 & 0,159 & 0,165 & 0,151 \\
\hline Soma $\sim A$ & 0,186 & 0,235 & 0,105 & 0.101 & 0.119 & 0,177 & 0,125 & 0,105 & 0,241 & 0,155 & 0,075 & 0,790 & 0,733 & 0,764 \\
\hline Cátions & 15,186 & 15,235 & 15,105 & 15,101 & 15,119 & 15,177 & 15,093 & 15,105 & 15.288 & 15,155 & 15,081 & 15,722 & 15,688 & 15,764 \\
\hline$m g \ddot{f}$ & 0,688 & $0,67 i$ & 0,728 & 0.726 & 0.715 & 0,499 & 0,528 & 0,512 & 0,473 & 0,488 & 0,376 & 0,302 & 0,248 & 0.382 \\
\hline
\end{tabular}

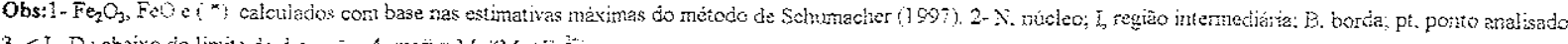




\begin{tabular}{|c|c|c|c|c|c|c|c|c|c|c|c|c|c|c|}
\hline \multicolumn{15}{|c|}{$\begin{array}{l}\text { Tabela V.3. Contimuaço } \\
\text { Fä́cies }\end{array}$} \\
\hline $\begin{array}{l}\text { Fácies } \\
\text { Amostra }\end{array}$ & \multicolumn{3}{|c|}{$\begin{array}{c}\text { Rectra Hibrida } \\
34 \mathrm{~B}\end{array}$} & \multicolumn{5}{|c|}{$\begin{array}{l}\text { Rocila Hibrida } \\
32 \mathrm{H}\end{array}$} & \multirow{2}{*}{\multicolumn{6}{|c|}{$\begin{array}{c}\text { Enclase Montonitico } \\
\text { GC }\end{array}$}} \\
\hline Analise & $p \hat{\theta}$ & pllo & $m l i$ & $p t i$ & $m^{2}$ & $p+3$ & pit & $n^{5}$ & $y t$ & & & & & \\
\hline Localiza $\_\tilde{f} a \hat{a} o$ & $i$ & $1 . E$ & $B$ & $B$ & Bi & ${ }_{i 3}$ & $I-13$ & $y$ & int & $l_{i=1}^{p r}$ & $i_{i}^{n t s}$ & $m(6)$ & $m^{7}$ & $p: B$ \\
\hline $\mathrm{SiO}_{2}$ & 45,42 & 44,89 & 46,38 & 51,16 & 48,27 & 49,30 & 48,53 & 49,60 & 45,33 & 49,68 & 50,02 & $\begin{array}{l}1.8 \\
49.54\end{array}$ & $\begin{array}{c}1-13 \\
49.52\end{array}$ & $\begin{array}{c}B \\
99,53\end{array}$ \\
\hline $\mathrm{TiO}_{2}$ & 3.34 & 1.16 & 1.24 & 0,59 & $1,1.4$ & 1.08 & 1.24 & $0, \xi$ & 1.32 & 0.11 & 0,34 & 0.39 & 1,05 & $\because, \cdots$ \\
\hline $\begin{array}{l}\mathrm{Al}_{2} \mathrm{O}_{3} \\
\mathrm{Fe}_{2} \mathrm{O}_{3}\end{array}$ & 5.17 & $\begin{array}{r}5.9 .4 \\
<\mathrm{L} . \mathrm{D}\end{array}$ & 3,96 & 3.55 & 192 & 4,60 & 5.05 & 3,66 & 57 & 3,34 & 2,57 & 2.97 & 1.38 & $1.4 !$ \\
\hline $\begin{array}{l}\mathrm{Fe}_{2} \mathrm{O}_{3} \\
\mathrm{FeO}\end{array}$ & $\begin{array}{l}4,6,1 \\
23, \pi\end{array}$ & $\begin{array}{l}<L, D \\
-5,00\end{array}$ & 2.72 & 5.48 & 4.58 & 4.74 & 4.32 & 1,3 & 6,6 & 290 & 1.59 & 1,0 & 6.84 & on: \\
\hline AnO & 82 & 0,76 & $\frac{25,43}{1,01}$ & 11,02 & $\begin{array}{l}12.69 \\
10.35\end{array}$ & 12.21 & 13.6 & 35,3 & $2, \%$ & 21.1 & 26.31 & 2172 & 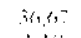 & $3 x$ \\
\hline MgO & 6,35 & 6,72 & 4,87 & 13,86 & $\begin{array}{l}10.35 \\
12.81\end{array}$ & $\begin{array}{l}0,37 \\
13,29\end{array}$ & $\begin{array}{l}1,32 \\
12,95\end{array}$ & $\begin{array}{l}0.35 \\
139\end{array}$ & $\begin{array}{l}1,41 \\
0.01\end{array}$ & 0.46 & 0 & 9.57 & 1,13 & 12 \\
\hline $\mathrm{CaO}$ & 9,32 & 0,58 & 8,55 & 11,35 & 11,10 & 11.14 & 11.18 & 10,7 & 1017 & 9,85 & 9,82 & 9,81 & 6,31 & 5.57 \\
\hline $\mathrm{Na}_{z} \mathrm{O}$ & 2,55 & $2.6 \mathrm{i}$ & 2.10 & 0.78 & 1,19 & 1.05 & 1.09 & 0,87 & 197 & $\begin{array}{l}3,83 \\
1,05\end{array}$ & 7,13 & 8,95 & 2.75 & 79.4 \\
\hline $\mathrm{K}_{1} \mathrm{O}$ & 0,79 & 0,75 & 0,80 & 0.23 & 0.45 & 0.39 & 0.44 & 0,26 & 0.72 & $\begin{array}{l}1,105 \\
0,28\end{array}$ & 0,76 & 0.87 & 39 & 925 \\
\hline $\mathrm{ZnO}$ & 1.21 & 3.45 & 0.88 & $<.5$ & 018 & 0.24 & 0.064 & $\mathrm{LD}$ & 0.72 & 0,28 & 0,24 & 0,30 & I. D. & 0.11 \\
\hline $\mathrm{ZrO}_{2}$ & 0.3 .3 & 0,15 & 0.10 & 0,08 & $\therefore$ D & 0.07 & C. D. & $00 \%$ & 0,04 & 0,72 & 32 & 0,35 & (.) & . 1. 1? \\
\hline$F$ & 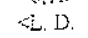 & $0,0 ?$ & 0,09 & $<\mathrm{L} . \mathrm{D}$ & L D. D. & $<\mathrm{L} . \mathrm{D}$ & L. D. & $<\mathrm{L} . \mathrm{D}$ & <. D & 0,07 & 0,05 & $\therefore \mathrm{BD}$. & 0.12 & $\therefore i n$ \\
\hline $\mathrm{Cl}$ & CD. D. & $\angle I . D$ & LL. D. & $<\mathrm{L} . \mathrm{D}$. & 0.06 & $<\mathrm{L}, \mathrm{D}$. & 0,06 & & & $<$ L. D. & $<$ L. D. & $<L . D$. & 005 & $\angle \mathrm{E} . \mathrm{D}$. \\
\hline Parcial & 98,88 & 99,08 & 99,11 & 98,61 & 97.71 & 98,54 & 98.42 & $\begin{array}{l}\text { L. Li. } \\
97.17\end{array}$ & 0.28 & 0,24 & 0,25 & 0,19 & 07 & 0,05 \\
\hline$O F_{-} C l$ & 0,01 & 0,03 & 0,04 & 0,00 & 0,02 & 0,02 & 0,01 & 0,01 & 99,7 & 99,9 & 99,9 & 99,7 & 99,4 & 99,0 \\
\hline Total & 98,87 & 99.05 & 99,07 & 98,61 & 97,69 & 98,51 & 98.40 & 97.16 & 0,06 & 0,05 & 0,06 & 0,05 & 0,04 & 0,02 \\
\hline \multirow{2}{*}{\multicolumn{15}{|c|}{ Fórmula estrutural* }} \\
\hline & & & & & & & & & & & & & & \\
\hline $\mathbf{A l}^{\mathbb{N}}$ & 0,947 & 1,080 & 0,732 & $\begin{array}{l}7,395 \\
0605\end{array}$ & $?, 142$ & 7,208 & 7,125 & 7,359 & 6,930 & 7,445 & 7544 & 7,472 & 7,745 & 7.736 \\
\hline Soma $T$ & 8,090 & 8000 & 8,000 &, 603 & 0,858 & 0,792 & 0,875 & $0,64 !$ & 1,029 & 0,555 & 0,456 & 0,528 & 0,255 & 0,260 \\
\hline$A \mathrm{~d}^{\mathrm{Vi}}$ & 0,000 & 0,000 & 0,000 & 0,000 & $\begin{array}{l}8,000 \\
0,000\end{array}$ & $\begin{array}{r}8,000 \\
0,000\end{array}$ & 8,000 & $\begin{array}{l}8,000 \\
0,000\end{array}$ & 7,959 & 8,000 & 8,000 & 8,000 & 8,000 & 7,996 \\
\hline $\mathrm{Ti}$ & 0,157 & 0,134 & 0,146 & 0,075 & 0,126 & 0,119 & 0,135 & 0,087 & 0,152 & 0.046 & $\begin{array}{l}0,000 \\
0,038\end{array}$ & 0,000 & 0,000 & $\begin{array}{l}0,000 \\
0,000\end{array}$ \\
\hline $\mathrm{Zr}$ & 0,010 & 0,012 & 0,008 & 0,006 & 0,000 & 0,005 & 0,000 & 0,005 & 0,005 & 0,005 & 0,006 & 0,044 & 0,006 & 0,000 \\
\hline $\mathrm{Fe}^{37}$ & 0,255 & 0,000 & 0,137 & 0,581 & 0,474 & 0.473 & 0,462 & 0,143 & 0,000 & $0,0,171$ & $\begin{array}{l}0,004 \\
0,107\end{array}$ & $\begin{array}{l}0,002 \\
0,041\end{array}$ & 0,009 & 0,000 \\
\hline $\mathrm{Mg}$ & 1,469 & 1,544 & 1,137 & 2,985 & 2.833 & 2,898 & 2,835 & 3,090 & 2,055 & 2,207 & 2,208 & $\begin{array}{l}0,041 \\
2,205\end{array}$ & 0.096 & 0,000 \\
\hline $\mathrm{z}$ & 0,142 & 0,165 & 0,102 & 0,005 & 0,020 & 0,026 & 0,000 & 0,000 & 0,106 & 0,080 & 0,036 & $\begin{array}{l}2,205 \\
0,039\end{array}$ & $\begin{array}{l}1,470 \\
0,000\end{array}$ & $\begin{array}{l}1,298 \\
0,000\end{array}$ \\
\hline $\mathrm{Fe}^{2+}$ & 2,968 & 2,807 & 3,470 & 1,348 & 1,545 & 1.480 & 1,558 & 1,676 & 2,682 & 2.490 & 2,608 & 2,670 & $\begin{array}{l}0,000 \\
3,414\end{array}$ & 3.694 \\
\hline$M_{n}$ & 0,000 & 0,000 & 0,000 & 0,000 & 0,000 & 0,000 & 0,000 & 0,000 & 0,000 & 0,000 & 0,000 & 0,000 & 0,000 & 0,000 \\
\hline Soma $-C$ & 5,000 & 5,000 & 5,000 & $\begin{array}{l}5,000 \\
0,000\end{array}$ & $\begin{array}{l}5,000 \\
0,000\end{array}$ & $\begin{array}{l}5,000 \\
0,000\end{array}$ & $\begin{array}{l}5,000 \\
0,000\end{array}$ & 5,000 & 5,000 & 5,000 & 5,000 & 5,000 & 5,000 & 5,000 \\
\hline$M_{R}$ & 0,000 & $\begin{array}{l}0,000 \\
0,000\end{array}$ & $\begin{array}{l}0,000 \\
0,000\end{array}$ & $\begin{array}{l}0,000 \\
0,000\end{array}$ & 0,000 & $\begin{array}{l}0,000 \\
0,000\end{array}$ & $\begin{array}{l}0,000 \\
0,000\end{array}$ & 0,000 & 0,000 & 0,000 & 0,000 & 0,000 & 0,000 & 0,000 \\
\hline$\underset{\mathrm{Fe}^{2+}}{\mathrm{Zn}}$ & $\begin{array}{l}0,000 \\
0,059\end{array}$ & $\begin{array}{l}0,000 \\
0,079\end{array}$ & 0,174 & 0,000 & 0,052 & 0,061 & 0073 & 236 & 0,000 & 0,000 & 0,000 & 0,000 & 0.000 & 0,000 \\
\hline $\begin{array}{l}\text { Fe } \\
\text { Mn }\end{array}$ & 0,108 & 0,099 & 0.134 & 0.044 & $0,0,4$ & 0045 & 0,040 & 0,057 & 0,358 & 0,329 & 0,771 & 0,522 & 1,385 & 0,602 \\
\hline $\mathrm{Ca}$ & 1,550 & 1.582 & 436 & 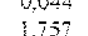 & & $\begin{array}{l}0,046 \\
1745\end{array}$ & 0,040 & 8,057 & 0,053 & 0,051 & 0,076 & 0,073 & 9157 & 0,148 \\
\hline $\mathbf{Y}_{\mathbf{3}}$ & 0,282 & 0.240 & 0,256 & 0,198 & $\begin{array}{l}1,61 \\
0,134\end{array}$ & $\begin{array}{l}1,745 \\
0,149\end{array}$ & $\begin{array}{l}1,759 \\
0,129\end{array}$ & 1,714 & 1,667 & 1,582 & 1,152 & 1,447 & 0,461 & 3,328 \\
\hline Soma-B & 2,000 & 2,000 & 2,000 & 2,000 & 2.000 & & 0,129 & 0,000 & 0,000 & 0,039 & 0,001 & 0,000 & 0.000 & 0,000 \\
\hline $\mathrm{Na}$ & 0,485 & $0,54 ?$ & 0,382 & 0,020 & 0,175 & $\begin{array}{l}2,1700 \\
0.149\end{array}$ & $\begin{array}{l}2,000 \\
0,181\end{array}$ & $\begin{array}{r}2,008 \\
0,50\end{array}$ & 2,077 & 2,000 & 2,000 & 2,042 & 2,003 & 2.078 \\
\hline $\mathrm{K}$ & 0,157 & 0,148 & 0,161 & 0,042 & 0,085 & 0,072 & 0,082 & 0,049 & $\begin{array}{l}0,383 \\
0.41\end{array}$ & 0,266 & 0,222 & 0,254 & 0.18 & 0,089 \\
\hline Soma $A$ & $0,6 \pm 2$ & 0,689 & 0,543 & 0,062 & 0.260 & 0.221 & 0.263 & $0 \rightarrow 99$ & 4 & 0,053 & 0,046 & 0,058 & 0,000 & 0,022 \\
\hline Cátions & 15,642 & 15,689 & 15,543 & 15.062 & 15,260 & 15.221 & 15,263 & $\begin{array}{l}0.487 \\
1 \leqslant 307\end{array}$ & $\begin{array}{l}0.723 \\
15.760\end{array}$ & 0,319 & 0,267 & 0,312 & 0.123 & 0,111 \\
\hline$m g \#$ & 0,327 & 0,349 & 0,238 & 0,680 & 0,638 & 0.653 & 0.635 & 0.618 & $\begin{array}{l}15,600 \\
0,403\end{array}$ & 15,319 & 15,267 & 15,354 & 15.126 & 15,184 \\
\hline & & & & & & & & & & 0.439 & 0,395 & 0,409 & 0.235 & 0,232 \\
\hline
\end{tabular}




\begin{tabular}{|c|c|c|c|c|c|c|c|c|c|c|c|c|c|c|c|}
\hline $\begin{array}{l}\text { Fácies } \\
\text { Amostra }\end{array}$ & \multicolumn{6}{|c|}{$\begin{array}{c}\text { Sienito Róseo Fino } \\
44 \mathrm{~B}\end{array}$} & \multicolumn{5}{|c|}{$\begin{array}{c}\text { Sienito Róseo Grosso } \\
\mathbf{5 1}\end{array}$} & \multicolumn{4}{|c|}{$\begin{array}{c}\text { Sienito Róseo Grosso } \\
51\end{array}$} \\
\hline Análise & $p t 1$ & $p: 4$ & $p t 5$ & $p t 6$ & $p t^{7}$ & pts & ptz/grâol & $p t 3 / g r a ̃ o l$ & pt4/gräol & pts/grāol & pt\&/grâol & $p t 3 / g r \bar{a} o 2$ & pt4/grãoz & pts/grão2 & pt6/grâo? \\
\hline Localizaf̧ão & $\begin{array}{c}B \\
47,74\end{array}$ & $\begin{array}{c}\mathrm{N}-\mathrm{I} \\
47,79\end{array}$ & $\begin{array}{c}1 \\
4685\end{array}$ & $\begin{array}{l}I-B \\
4850\end{array}$ & $B$ & $B$ & $N$ & I & $i$ & $I-B$ & $B$ & $I-B$ & 1 & 1 & $N$ \\
\hline $\mathrm{SiO}_{2}$ & $\begin{array}{c}47,74 \\
1,62\end{array}$ & 47,79 & 46,85 & 48,59 & 47,09 & 48,11 & 46,83 & 48,08 & $48,4 \hat{3}$ & 48,14 & 49,16 & 47,06 & 46,70 & 46,67 & 47,57 \\
\hline $\mathrm{TiO}_{2}$ & $\begin{array}{l}1,62 \\
1,25\end{array}$ & $\begin{array}{l}1,43 \\
1,00\end{array}$ & 0,30 & 0,13 & 0,02 & $\begin{array}{l}1,67 \\
1,03\end{array}$ & 1,16 & 1,24 & 1,03 & 0,73 & 0,34 & 1,46 & 1,35 & 1,32 & 1,24 \\
\hline $\mathrm{Al}_{2} \mathrm{O}_{3}$ & $\begin{array}{r}1,25 \\
<L D\end{array}$ & 1,00 & 1,35 & 1,01 & 3,52 & 1,03 & 0,20 & 1,88 & 1,97 & 1,72 & 1,32 & 2,15 & 2,20 & 2,22 & 2,16 \\
\hline $\mathrm{Fe}_{2} \mathrm{O}_{3}$ & $<L . D$ & <L. D. & 1,21 & 4,14 & 4,40 & 0,44 & $\because \mathrm{L} . \mathrm{D}$. & <L. D. & $<\mathrm{L}$. D. & $<\mathrm{L} . \mathrm{D}$ & 0,75 & $<$ L. D. & <L. D. & <L. D. & 1,00 \\
\hline $\mathrm{FeO}$ & 34,65 & 34,72 & 35,14 & 33,12 & $29,1 \mathrm{~A}$ & 33,66 & 30,77 & 30,59 & 29,92 & 28,70 & 31,60 & 31,95 & 31,56 & 31.60 & 30,07 \\
\hline Mno & 1,11 & $1: 10$ & 0,98 & 1,20 & 1,41 & 1,06 & 0.79 & 0,75 & 0,71 & 0,66 & 0.71 & 0,75 & 0,81 & 0,79 & 1,02 \\
\hline $\mathrm{MgO}$ & 0,40 & 0,54 & 0,40 & 0,38 & 0,82 & 0,63 & 3,87 & 4,21 & 4,67 & 5,61 & 3,66 & 3,16 & 3,18 & 3,13 & 3,22 \\
\hline CaO & 4,87 & 4,72 & 7,01 & 6,68 & 9,58 & 4,92 & 6,89 & 7,08 & 7,25 & 7,45 & 8.44 & 6,50 & 6,61 & 6,67 & 6,73 \\
\hline $\mathrm{Na}_{2} \mathrm{O}$ & 4,88 & 4,93 & 2,66 & 2,59 & 1,06 & 4,78 & 3,25 & 3,37 & 3,35 & 3,35 & 1,94 & 3,34 & 3,71 & 3,52 & 3,36 \\
\hline $\mathrm{K}_{2} \mathrm{O}$ & 1,27 & 1,13 & 0,63 & 0,37 & 0,24 & 1,13 & 0,83 & $0,7 ?$ & 0,76 & 0,75 & 0,53 & 0,95 & 0,92 & 0,93 & 0,89 \\
\hline $\mathrm{ZnO}$ & 0,90 & 1,03 & 0,32 & 0,50 & 0,06 & 1,08 & 0,88 & 1,14 & 1,05 & 0,94 & $0,6 ?$ & 0,91 & 1,08 & 1,13 & 0,58 \\
\hline $\mathrm{Zr}_{\mathrm{rO}}$ & 0,13 & 0,08 & 0,06 & 0,14 & $<\mathrm{L}$. D. & 0,09 & 0,11 & 0.14 & 0,09 & 0,14 & 0,10 & 0,11 & $0,0 \%$ & 0,13 & 0,13 \\
\hline $\mathrm{F}$ & 0,12 & 0,12 & $<\mathrm{L} . \mathrm{D}$. & $<$ L. D. & $<$ L. D. & 0,07 & $<\mathrm{I}, \mathrm{D}$. & $<$ L. D. & <L. D. & 0,05 & $<$ L. D. & 0,32 & 0,25 & 0,29 & 0,20 \\
\hline $\mathrm{Cl}$ & 0,05 & $<\mathrm{L} . \mathrm{D}$. & 0,10 & 0,10 & $<$ L.D. & 0,07 & 0,06 & 0,09 & 0,09 & 0,11 & 0,12 & 0,07 & 0,07 & 0,08 & 0,06 \\
\hline Parcial & 99,0 & 98,6 & 97,0 & 98,9 & 97,3 & 98,7 & 95,6 & 99,4 & 99,3 & 98,3 & 99,3 & 98,7 & 98,5 & 98,5 & 98,2 \\
\hline$O_{-} F_{-} C l$ & 0,06 & 0,05 & 0,02 & 0,02 & 0,00 & 0,05 & 0,01 & 0,03 & 0,02 & 0,05 & 0,03 & 0,15 & 0,12 & 0,14 & 0,10 \\
\hline Total & 98,9 & 98,6 & 97,0 & 98,9 & 97,3 & 98,7 & 95,6 & 99.3 & 99,3 & 98,3 & 993 & 98,6 & 98,4 & 98,3 & 98,1 \\
\hline \multicolumn{16}{|c|}{ Fórmula estrutural* } \\
\hline $\mathrm{Si}$ & 7,722 & 7,759 & 7,738 & 7,810 & 7,537 & 7,771 & 7,707 & 7,566 & 7,585 & 7,590 & 7,742 & 7,530 & 7,496 & 7,500 & 7,594 \\
\hline $\mathbf{A l}^{\mathbf{N}}$ & 0,239 & 0,191 & 0,262 & 0,190 & 0,463 & 0,196 & 0,039 & 0,348 & 0,364 & 0,319 & 0,245 & 0,405 & 0,417 & 0,423 & 0,406 \\
\hline Soma-T $T$ & 7,961 & 7,950 & 8,000 & 8,000 & 8,000 & 7,967 & 7,746 & 7,915 & 7,949 & 7,909 & 7,987 & 7,935 & 7,913 & 7,921 & 8,000 \\
\hline $\mathbf{A l}^{\mathbf{n}}$ & 0,000 & $\begin{array}{l}0,000 \\
0,174\end{array}$ & 0,000 & $\begin{array}{l}0,000 \\
0,016\end{array}$ & $\begin{array}{l}0,201 \\
0,003\end{array}$ & $\begin{array}{l}0,000 \\
0,03\end{array}$ & 0,000 & 0,000 & 0,000 & 0,000 & 0,000 & 0,000 & 0,000 & 0,000 & 0,000 \\
\hline $\mathrm{Ti}$ & $\begin{array}{l}0,197 \\
0,010\end{array}$ & $\begin{array}{l}0,174 \\
0,006\end{array}$ & 0,037 & $\begin{array}{l}0,016 \\
0,011\end{array}$ & $\begin{array}{l}0,003 \\
0,000\end{array}$ & $\begin{array}{l}0,203 \\
0,007\end{array}$ & 0,144 & 0,146 & 0,121 & 0,086 & 0,040 & $\begin{array}{l}0,175 \\
0,008\end{array}$ & 0,163 & 0,159 & 0,149 \\
\hline $\mathbf{Z x}$ & 0,010 & 0,006 & 0,005 & $\begin{array}{l}0,011 \\
0,372\end{array}$ & 0,000 & 0,000 & 0,009 & 0,011 & 0,007 & 0,011 & 0,008 & 0,008 & 0,006 & 0,010 & 0,010 \\
\hline $\mathrm{Fe}^{2+}$ & 0,000 & 0,000 & 0,068 & 0,372 & 0,533 & $\begin{array}{l}0,000 \\
0,151\end{array}$ & 0,000 & 0,000 & 0,000 & 0,000 & 0,000 & 0,000 & 0,000 & 0,000 & 0,036 \\
\hline $\mathbf{M g}$ & 0,097 & 0,132 & 0,099 & 0,090 & 0,196 & 0,151 & 0,950 & 0,987 & 1,091 & 1,319 & 0,858 & 0,754 & 0,762 & 0,749 & 0,765 \\
\hline $\mathrm{Zu}$ & 0,107 & 0,124 & 0,039 & 0,059 & 0,000 & 0,129 & 0,107 & 0,133 & 0,122 & 0,109 & 0,078 & 0,107 & 0,128 & 0,134 & 0,068 \\
\hline $\mathrm{Fe}^{2+}$ & 4,589 & 4,564 & 4,751 & 4,452 & 3,898 & 4,510 & 3,791 & 3,723 & 3,659 & 3,474 & 4,017 & 3,955 & 3,942 & 3,948 & 3,972 \\
\hline Mn & 0,000 & 0,000 & 0,000 & 0,000 & 0,161 & 0,000 & 0,000 & 0,000 & 0,000 & 0,000 & 0,000 & 0,000 & 0,000 & 0,000 & 0,000 \\
\hline Soma-C & $\begin{array}{l}5,000 \\
0,000\end{array}$ & $\begin{array}{l}5,000 \\
0,000\end{array}$ & $\begin{array}{l}5,000 \\
0,000\end{array}$ & $\begin{array}{l}5,000 \\
0,000\end{array}$ & $\begin{array}{l}5,000 \\
0,000\end{array}$ & $\begin{array}{l}5,000 \\
0,000\end{array}$ & $\begin{array}{l}5,000 \\
0,000\end{array}$ & 5,000 & $\begin{array}{l}5,000 \\
0,000\end{array}$ & 5,000 & 5,000 & 5,000 & 5,000 & 5,000 & 5,000 \\
\hline Mg & 0,000 & $\begin{array}{l}0,050 \\
0,000\end{array}$ & $\begin{array}{l}0,000 \\
0,000\end{array}$ & $\begin{array}{l}0,000 \\
0,000\end{array}$ & 0,0000 & $\begin{array}{l}0,000 \\
0,000\end{array}$ & $\begin{array}{l}0,000 \\
0,000\end{array}$ & $\begin{array}{l}0,000 \\
0,000\end{array}$ & 0,000 & 0,000 & 0,000 & 0,000 & 0,000 & 0,000 & $\begin{array}{l}0,000 \\
0,000\end{array}$ \\
\hline $\begin{array}{l}\mathrm{Zn} \\
\mathrm{Fe}^{2+}\end{array}$ & $\begin{array}{l}0,000 \\
0,098\end{array}$ & $\begin{array}{l}0,000 \\
0,150\end{array}$ & $\begin{array}{l}0,000 \\
0,185\end{array}$ & $\begin{array}{l}0,000 \\
0,129\end{array}$ & $\begin{array}{l}0,000 \\
0,000\end{array}$ & $\begin{array}{l}0,000 \\
0,091\end{array}$ & $\begin{array}{l}0,000 \\
0,444\end{array}$ & $\begin{array}{l}0,000 \\
0,303\end{array}$ & $\begin{array}{l}0,000 \\
0,259\end{array}$ & $\begin{array}{l}0,000 \\
0,309\end{array}$ & $\begin{array}{l}0,000 \\
0,234\end{array}$ & $\begin{array}{l}0,000 \\
0,320\end{array}$ & $\begin{array}{l}0,000 \\
0,295\end{array}$ & $\begin{array}{l}0,000 \\
0,300\end{array}$ & $\begin{array}{l}0,000 \\
0,127\end{array}$ \\
\hline $\mathrm{Mn}$ & 0,153 & 0,151 & 0,137 & 0,163 & 0,029 & 0,144 & 0,110 & 0,099 & 0,095 & 0,088 & 0,094 & 0,101 & 0,110 & 0,107 & 0,138 \\
\hline $\mathrm{Ca}$ & 0,844 & 0,822 & 1,241 & 1,150 & 1,643 & 0,852 & 1,215 & 1,194 & 1,217 & 1,259 & 1,423 & 1,113 & 1,137 & 1,149 & 1,151 \\
\hline $\mathbf{N a}$ & 0,906 & 0,877 & 0,437 & 0,559 & 0,328 & 0,912 & 0,231 & 0,404 & 0,429 & 0,343 & 0,248 & 0,466 & 0,459 & 0,444 & 0,585 \\
\hline Soma-B & 2,000 & 2,000 & 2,000 & 2,000 & 2,000 & 2,000 & 2,000 & 2,000 & 2,000 & 2,000 & 2,000 & 2,000 & 2,000 & 2,000 & 2,000 \\
\hline $\mathbf{N a}$ & 0,624 & 0,675 & 0,414 & 0,247 & 0,000 & 0,586 & 0,805 & 0,625 & 0,590 & 0,680 & 0,344 & 0,571 & 0,697 & 0,652 & 0,455 \\
\hline K & 0,262 & 0,233 & 0,132 & 0,076 & 0,048 & 0,234 & 0,175 & 0,155 & 0,151 & 0,351 & 0,106 & 0,194 & 0,189 & 0,190 & 0,182 \\
\hline Soma-A & 0,886 & 0,908 & 0,546 & 0,323 & 0,048 & 0,820 & 0,980 & 0,780 & 0,741 & 0,831 & 0,450 & 0,765 & 0,886 & 0,842 & 0,637 \\
\hline Cátions & 15,847 & 15,858 & 15,546 & 15,323 & 15,048 & 15,787 & 15,726 & 15,695 & 15,690 & 15,740 & 15,437 & 15,700 & 15,799 & 15,763 & 15,637 \\
\hline$m g \#$ & 0,020 & 0,027 & 0,020 & 0,019 & 0,048 & 0,032 & 0,183 & 0,197 & 0,218 & 0,258 & 0,168 & 0,150 & 0,152 & 0.150 & 0,157 \\
\hline
\end{tabular}




\begin{tabular}{|c|c|c|c|c|c|c|c|c|c|c|c|c|c|c|c|}
\hline \multirow{2}{*}{$\begin{array}{l}\text { Fácies } \\
\text { Amostra } \\
\text { Análise }\end{array}$} & \multicolumn{5}{|c|}{$\begin{array}{c}\text { Sienito Róseo Grosso } \\
51\end{array}$} & \multicolumn{6}{|c|}{$\begin{array}{l}\text { Sienito Verde Grosso } \\
32 \mathrm{C}\end{array}$} & \multicolumn{4}{|c|}{$\begin{array}{c}\text { Sienito Verde Grosso } \\
50 \mathrm{~A}\end{array}$} \\
\hline & pt7/grão? & pt8/grão2 & $p t 9 / g r a ̈ o 2$ & pt10/grão2 & pt1l/grãoz & $p t i$ & $p t 2$ & $p t 3$ & $p t^{4}$ & $p t^{5}$ & $p t 6$ & $p t s$ & $p t 6$ & $p t 9$ & pt10 \\
\hline $\begin{array}{c}\text { Localizaçäo } \\
\mathrm{SiO}_{2}\end{array}$ & $\begin{array}{c}N-1 \\
47,26\end{array}$ & $\begin{array}{c}I \\
47,69\end{array}$ & $\begin{array}{c}I \\
48,85\end{array}$ & $\begin{array}{c}I-B \\
49,01\end{array}$ & $\begin{array}{c}B \\
48,45\end{array}$ & $\underset{47,31}{N}$ & $\begin{array}{c}N-I \\
47,58\end{array}$ & $\begin{array}{c}I \\
47,23\end{array}$ & $\begin{array}{c}I \\
47,18\end{array}$ & $\begin{array}{c}1 \\
47.07\end{array}$ & $\begin{array}{c}I \\
4617\end{array}$ & $\begin{array}{c}I \\
47.07\end{array}$ & $I$ & ${ }_{A-B}$ & $B$ \\
\hline $\mathrm{TiO}_{2}$ & 1,43 & 1,21 & 0,17 & 0,26 & $0,0 s$ & 1,06 & 1,13 & 1,24 & 0,78 & $\begin{array}{l}4 /, 0 / \\
0,61\end{array}$ & $\begin{array}{l}46,17 \\
0,51\end{array}$ & 47,07 & 46,17 & 46,63 & $\begin{array}{l}47,89 \\
0,32\end{array}$ \\
\hline $\mathrm{Al}_{2} \mathrm{O}_{3}$ & 2,12 & 1,82 & 1,00 & 1,34 & 0,50 & 2,69 & 2,58 & 2,35 & 2,49 & 2,42 & $\begin{array}{l}0,51 \\
3,06\end{array}$ & $\begin{array}{l}0,61 \\
2,42\end{array}$ & $\begin{array}{l}0,51 \\
3,06\end{array}$ & $\begin{array}{l}0,36 \\
2,81\end{array}$ & $\begin{array}{l}0,32 \\
1,27\end{array}$ \\
\hline $\mathrm{Fe}_{2} \mathrm{O}_{3}$ & <L. D. & <L. D. & 1,85 & 2,36 & <L. D. & $<\mathrm{L} . \mathrm{D}$. & $\angle \mathrm{L} . \mathrm{D}$. & $<\mathrm{L} . \mathrm{D}$. & LL.D. & $<\mathrm{L} . \mathrm{D}$. & 0,15 & $\angle \mathrm{L}, \mathrm{D}$ & 0,15 & 0,79 & <L. D. \\
\hline $\mathrm{F} \cdot \mathrm{O}$ & 31,15 & 31,35 & 32,66 & 29,27 & 42,07 & 29,09 & 29,39 & 30,54 & 30,03 & 30,69 & 32,53 & 30,69 & 32,53 & 33,78 & 34,20 \\
\hline Mno & 0,80 & 0,83 & 0,79 & 0,80 & 2,01 & 0,69 & 0,60 & 0,70 & 0,64 & 0,67 & 0,65 & 0,67 & 0,65 & 0,89 & 0,92 \\
\hline MgO & 3,28 & 3,53 & 2,19 & 3,80 & 1,97 & 4,99 & 4,93 & 3,99 & 4,59 & 4,44 & 3,07 & 4,44 & 3,07 & 2,42 & 2,05 \\
\hline $\mathrm{CaO}$ & 6,50 & 6,44 & 8,59 & 8,63 & 2,82 & 8,09 & 7,95 & 7,39 & 8,96 & 9,06 & 9,25 & 9,06 & 9,25 & 9,04 & 9,47 \\
\hline $\mathrm{Na}_{3} \mathrm{O}$ & 3,60 & 3,57 & 1,43 & 1,63 & 0,27 & 3,04 & 2,95 & 3,24 & 1,95 & 1,91 & 1,74 & 1,91 & 1,74 & 1,38 & 0,84 \\
\hline $\mathrm{K}_{2} \mathrm{O}$ & 0,97 & 0,88 & 0,24 & 0,43 & 0,02 & 0,83 & 0,88 & 0,92 & 0,58 & 0,58 & 0,63 & 0,58 & 0,63 & 0,43 & 0,22 \\
\hline $\mathrm{ZnO}$ & 1,11 & 0,74 & 0,59 & 0,49 & 0,27 & 1,02 & 0,98 & 0,71 & 0,68 & 0,49 & 0,74 & 0,49 & 0,74 & 0,24 & 0,20 \\
\hline $\mathrm{ZrO}_{2}$ & 0,16 & 0,07 & 0,06 & 0,08 & 0,11 & $<\mathrm{L} . \mathrm{D}$. & 0,06 & 0,13 & 0,07 & 0,09 & 0,10 & 0,09 & 0,10 & $<\mathrm{L} . \mathrm{D}$. & 0,15 \\
\hline $\mathbf{F}$ & 0,24 & 0,07 & $\angle L, D$. & $<L . D$. & <L. D. & $<\mathrm{L} . \mathrm{D}$. & <L.D. & <L. D. & 0,07 & $<\mathcal{L} . \mathrm{D}$. & $<\mathrm{L} . \mathrm{D}$ & $<\mathrm{L} . \mathrm{D}$. & $\angle \mathrm{L} . \mathrm{D}$. & $<\mathrm{L} . \mathrm{D}$. & 0,06 \\
\hline $\mathrm{Cl}$ & 0,06 & 0,06 & 0,07 & 0,09 & 0,07 & 0,06 & 0,11 & 0,07 & 0,20 & 0,09 & 0,17 & 0,09 & 0,17 & 0,26 & 0,03 \\
\hline Parcial & 98,7 & 98,3 & 98,5 & 98,2 & 98,6 & 98,9 & 99,1 & 98,5 & 98,2 & 98,1 & 98,8 & 98,1 & 98,8 & 99,1 & 97,6 \\
\hline$O_{-} F_{-} C l$ & 0,11 & 0,04 & 0,02 & 0,03 & 0,02 & 0,01 & 0,02 & 0,03 & 0,07 & 0,02 & 0,05 & 0,02 & 0,05 & 0,06 & 0,03 \\
\hline Total & 98,6 & 98,2 & 98,5 & 98,2 & 98,6 & 98,9 & 99,1 & 98,5 & 98,1 & 98,1 & 98,7 & 98,1 & 98,7 & 99,0 & 97.6 \\
\hline \multicolumn{16}{|c|}{ Fórmula estrutural* } \\
\hline $\mathrm{Si}$ & 7,544 & 7,609 & 7,812 & 7,751 & 7,888 & 7,440 & 7,468 & 7,499 & 7,491 & 7,488 & 7,395 & 7,488 & 7,395 & 3,469 & 7,739 \\
\hline $\mathbf{A l}^{\mathrm{IV}}$ & 0,399 & 0,342 & 0,188 & 0,249 & 0,096 & 0,499 & 0,477 & 0,439 & 0,466 & 0,455 & 0,578 & 0,455 & 0,578 & 0,531 & 0,241 \\
\hline $\begin{array}{l}\text { Soma-T } \\
A^{V} I^{n}\end{array}$ & $\begin{array}{l}7,942 \\
0,000\end{array}$ & $\begin{array}{l}7,951 \\
0,000\end{array}$ & $\begin{array}{l}8,000 \\
0,000\end{array}$ & $\begin{array}{l}8,000 \\
0,000\end{array}$ & $\begin{array}{l}7,983 \\
0,000\end{array}$ & $\begin{array}{l}7,939 \\
0,000\end{array}$ & $\begin{array}{l}7,9,45 \\
0,000\end{array}$ & $\begin{array}{l}7,939 \\
0,000\end{array}$ & $\begin{array}{l}7,957 \\
0,000\end{array}$ & $\begin{array}{l}7,943 \\
0,000\end{array}$ & $\begin{array}{l}7,973 \\
0,000\end{array}$ & $\begin{array}{l}7,943 \\
0,000\end{array}$ & $\begin{array}{l}7,973 \\
0,000\end{array}$ & $\begin{array}{l}8,000 \\
0,000\end{array}$ & $\begin{array}{l}7,980 \\
0,000\end{array}$ \\
\hline $\mathbf{T}$ & 0,172 & 0,145 & 0,020 & 0,031 & 0,006 & 0,125 & 0,130 & 0,148 & 0,093 & 0,073 & 0,061 & 0,073 & 0,061 & 0,043 & 0,039 \\
\hline $\mathrm{Z}_{\boldsymbol{r}}$ & 0,012 & 0,006 & 0,004 & 0,006 & 0,009 & 0,000 & 0,005 & 0,010 & 0,005 & 0,607 & 0,008 & 0,007 & 0,008 & 0,000 & 0,012 \\
\hline $\mathrm{Fe}^{3+}$ & 0,000 & 0,000 & 0,079 & 0,166 & 0,000 & 0,000 & 0,000 & 0,000 & 0,000 & 0,000 & 0,000 & 0,000 & 0,000 & 0,036 & 0,000 \\
\hline $\mathbf{M g}$ & 0,781 & $0,8 \cdot 40$ & $0,52 \hat{3}$ & 0,895 & 0,477 & 1,170 & 1,154 & 0,943 & 1,086 & 1,053 & 0.732 & 1,053 & 0,732 & 0,578 & 0,493 \\
\hline $\mathrm{Zu}$ & 0,131 & 0,088 & 0,069 & 0,057 & 0,033 & 0,119 & 0,114 & 0,083 & 0,080 & 0,058 & 0.087 & 0,058 & 0,08 & 0,029 & 0,024 \\
\hline $\mathrm{Fe}^{2+}$ & 3,904 & 3,921 & 4,304 & $3,8: 44$ & 4,475 & 3,584 & 3,597 & 3.815 & 3,736 & 3,808 & 4,112 & 3,808 & 4,112 & 4,312 & 4,433 \\
\hline Mn & 0,000 & 0,000 & 0,000 & 0,000 & 0,000 & 0,000 & 0,000 & 0,000 & 0,000 & 0,000 & 0,000 & 0,000 & 0,000 & 0,000 & 0,000 \\
\hline Soma-C & 5,000 & 5,000 & 5.000 & 5,000 & 5,000 & 5,000 & 5,000 & 5,000 & 5,000 & 5,000 & 5,000 & 5,000 & 5,000 & 5,000 & 5,000 \\
\hline $\mathbf{M}$ & 0,000 & 0,000 & 0,000 & 0,000 & 0,000 & 0,000 & 0,000 & 0,000 & 0,000 & 0,000 & 0,000 & 0,000 & 0,000 & 0,000 & 0,000 \\
\hline $\mathbf{Z n}_{\mathbf{n}}$ & 0,000 & 0,000 & 0,000 & 0,000 & 0,000 & 0,000 & 0,000 & 0,000 & 0,000 & 0,000 & 0,000 & 0,000 & 0,000 & 0,000 & 0,000 \\
\hline $\mathrm{Fe}^{2+}$ & 0,255 & 0,262 & 0,206 & 0141 & 1,253 & 0,242 & 0,260 & 0,240 & 0,252 & 0,274 & 0,263 & 0,274 & 0,263 & 0,272 & 0,189 \\
\hline Mn & 0,108 & 0,113 & 0,107 & 0,108 & 0,277 & 0,092 & 0,080 & 0,094 & 0,086 & 0,090 & 0,088 & 0,090 & 0,088 & 0,121 & 0,126 \\
\hline $\mathrm{Ca}_{2}$ & $\{, 112$ & 1,101 & 1,472 & 1,463 & 0,491 & 1,364 & 1,337 & 1.258 & 1,524 & 1,544 & 1,587 & 1,544 & 1,587 & 1,552 & 1,640 \\
\hline $\mathrm{Na}$ & 0.524 & 0,524 & 0,215 & 0,288 & 0,000 & 0,302 & 0,324 & 0,408 & 0,138 & 0,092 & 0,062 & 0,092 & 0,062 & 0,055 & 0,045 \\
\hline Soma-B & $\begin{array}{l}2,000 \\
0,589\end{array}$ & $\begin{array}{l}2,000 \\
0,581\end{array}$ & 2,000 & $\begin{array}{l}2,000 \\
0,211\end{array}$ & $\begin{array}{l}2,022 \\
0,086\end{array}$ & 2,000 & 2,000 & $\begin{array}{l}2,000 \\
0.589\end{array}$ & $\begin{array}{l}2,000 \\
0,461\end{array}$ & 2,000 & 2,000 & 2,000 & 2,000 & 2,000 & $\begin{array}{l}2,000 \\
0,218\end{array}$ \\
\hline $\begin{array}{l}\mathbf{N a} \\
\mathbf{K}\end{array}$ & $\begin{array}{l}0,589 \\
0,197\end{array}$ & $\begin{array}{l}0,581 \\
0,179\end{array}$ & $\begin{array}{l}0,227 \\
0,049\end{array}$ & $\begin{array}{l}0,211 \\
0,086\end{array}$ & $\begin{array}{l}0,086 \\
0,004\end{array}$ & $\begin{array}{l}0,623 \\
0,167\end{array}$ & $\begin{array}{l}0,574 \\
0,176\end{array}$ & $\begin{array}{l}0,589 \\
0,186\end{array}$ & $\begin{array}{l}0,461 \\
0,118\end{array}$ & $\begin{array}{l}0,498 \\
0,118\end{array}$ & $\begin{array}{l}0,479 \\
0,130\end{array}$ & $\begin{array}{l}0,498 \\
0,118\end{array}$ & $\begin{array}{l}0,479 \\
0,130\end{array}$ & $\begin{array}{l}0,373 \\
0,088\end{array}$ & $\begin{array}{l}0,218 \\
0,044\end{array}$ \\
\hline Soma-A & 0,786 & 0,760 & 0,276 & 0,297 & 0,089 & 0,790 & 0,750 & 0,775 & 0,579 & 0,616 & 0,609 & 0,616 & 0,609 & 0,461 & 0,263 \\
\hline Cátions & 15,728 & 15,711 & 15,276 & 15,297 & 15,094 & 15,729 & 15,695 & 15.714 & 15,536 & 15,558 & 15,582 & 15,558 & 15,582 & 15,461 & 15,243 \\
\hline$m g \#$ & 0,158 & 0,167 & 0,204 & 0,183 & 0,077 & 0,234 & 0,230 & 0,189 & 0,214 & 0,205 & 0,143 & 0,205 & 0,143 & 0,112 & 0,096 \\
\hline
\end{tabular}

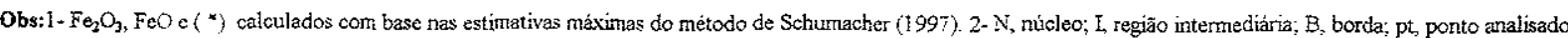

3-<L. D.: abaixo do limite de deteção. $4 \cdot \mathrm{mg}=\mathrm{Mg} /\left(\mathrm{Mg}_{\mathrm{q}}+\mathrm{Fe}^{2+}\right.$ 


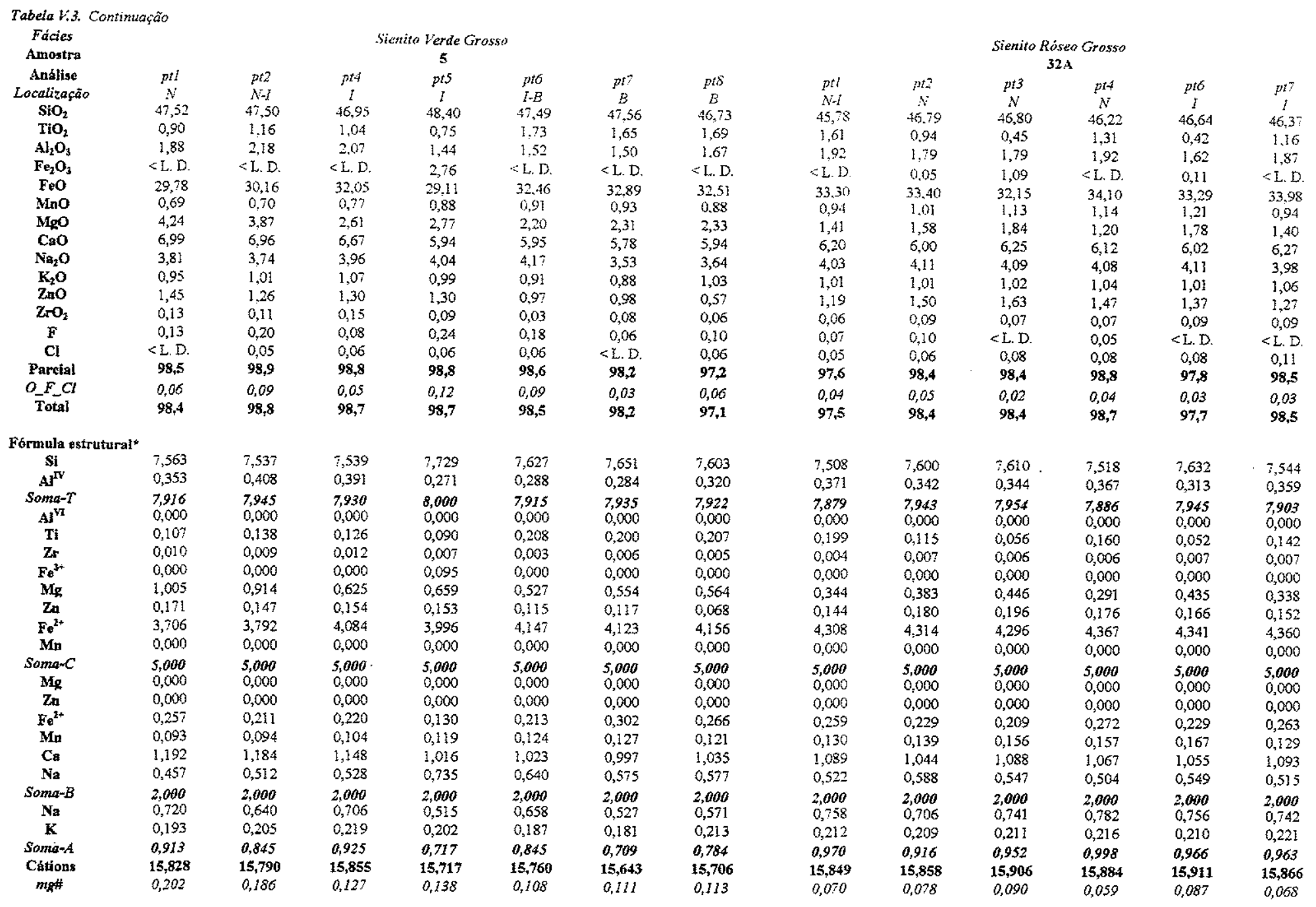

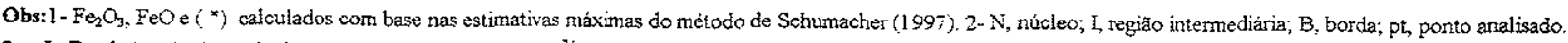




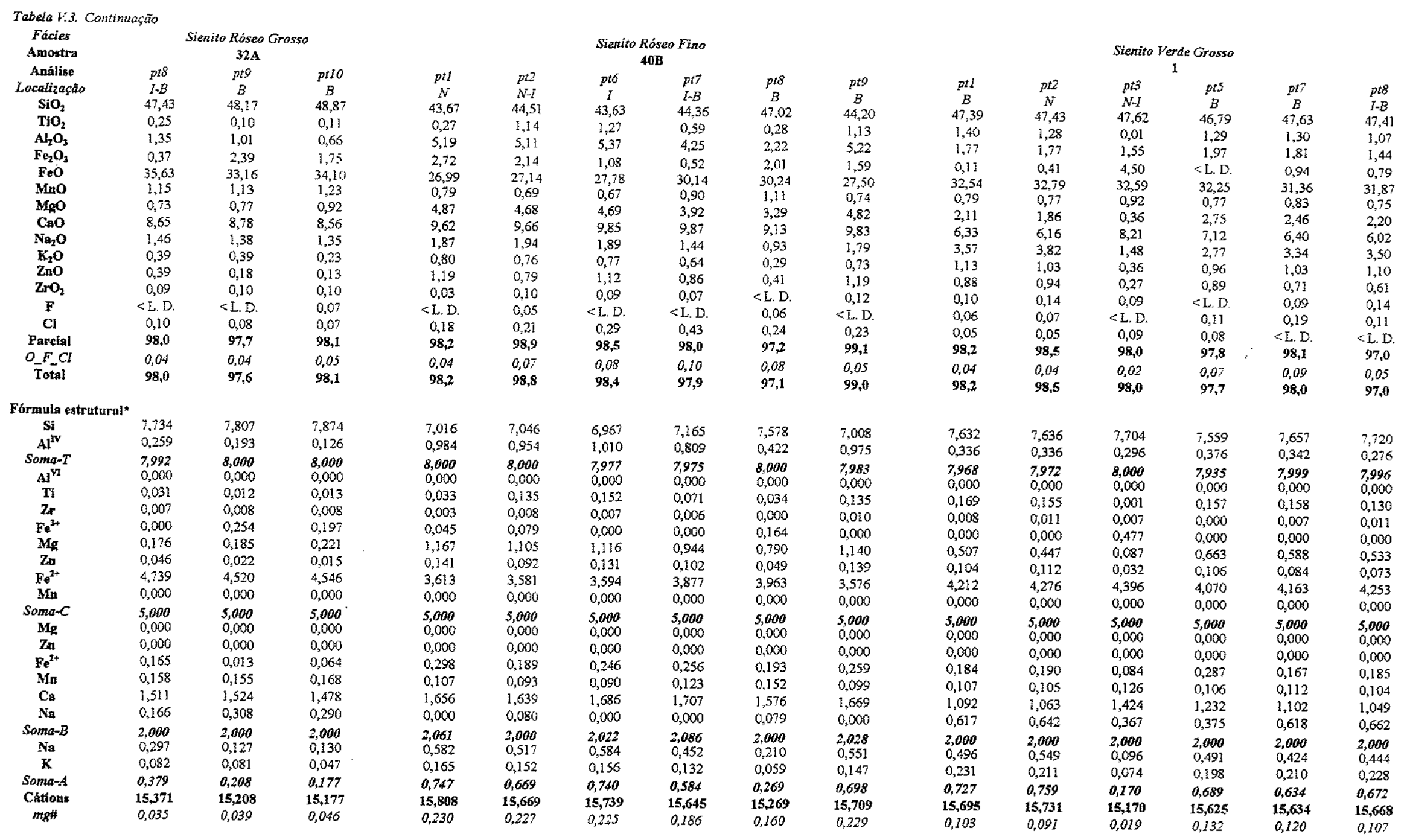




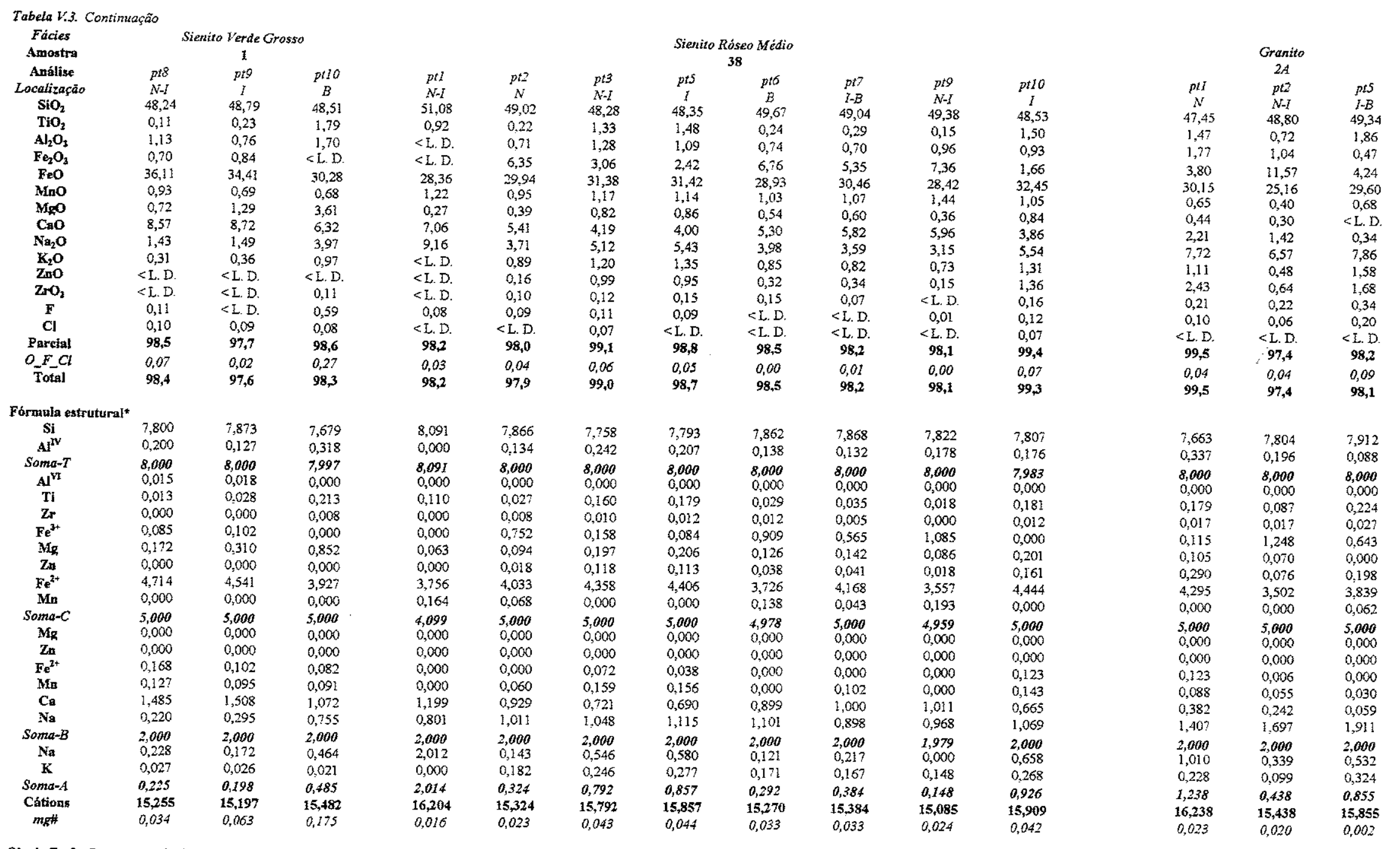

Obs: $1-\mathrm{Fe}_{2} \mathrm{O}_{3}, \mathrm{FeO}$ e ( ${ }^{*}$ ) calculados cont base nas estimativas máximas do método de Schumacher (1997). 2- N, núcleo; I região internediäria; $\mathrm{B}$, borda; pt, ponto analisado. 


\begin{tabular}{|c|c|c|c|}
\hline \multicolumn{4}{|c|}{ Tabela v:3. Continuação } \\
\hline Fácies & \multirow{2}{*}{\multicolumn{3}{|c|}{ Granito }} \\
\hline & & & \\
\hline Análise & $p t 6$ & & $p t \delta$ \\
\hline Localitą̧ăo & $I-B$ & $I-B$ & $\begin{array}{c}B \\
4912\end{array}$ \\
\hline $\begin{array}{l}\mathrm{SiO}_{2} \\
\mathrm{TiO}_{2}\end{array}$ & $\begin{array}{l}49,66 \\
0,63\end{array}$ & $\begin{array}{l}49,39 \\
0,99\end{array}$ & $\begin{array}{c}49,12 \\
0,67\end{array}$ \\
\hline $\mathrm{Al}_{2} \mathrm{O}_{3}$ & 0,48 & 0,80 & 1,05 \\
\hline $\mathrm{Fe}_{2} \mathrm{O}_{3}$ & 6,96 & 8,35 & 10,71 \\
\hline FeO & 24,16 & 21,54 & 26,14 \\
\hline MnO & 2,89 & $\begin{array}{l}2,2,24 \\
4,22\end{array}$ & $\begin{array}{l}20,14 \\
1,02\end{array}$ \\
\hline MEO & $<\mathrm{L}$. D. & <L.D. & 0,05 \\
\hline $\mathrm{CsO}$ & 0,05 & 0,02 & 1,90 \\
\hline $\mathrm{Na}_{2} \mathrm{O}$ & 6,75 & 7.14 & 6,18 \\
\hline $\mathrm{K}_{2} \mathrm{O}$ & 1,58 & 1,08 & 0,93 \\
\hline Zno & 1,07 & 3.27 & 0,62 \\
\hline $\mathrm{ZrO2}$ & 0,57 & 1,16 & 0,15 \\
\hline $\mathrm{F}$ & 1,28 & 0,32 & 0,06 \\
\hline $\mathrm{Cl}$ & $\angle L D$ & $\angle I . D$. & $<\mathrm{L} . \mathrm{D}$. \\
\hline Parcial & 96,1 & 96,3 & 98,6 \\
\hline $\mathrm{O}_{-} \mathrm{F}_{-} \mathrm{Cl}$ & 0,54 & 0,14 & 0,03 \\
\hline Total & 95,5 & 96,2 & $\mathbf{9 8 , 6}$ \\
\hline \multicolumn{4}{|c|}{ Fórmula estrutural* } \\
\hline Si & 8,103 & 7,978 & 7,804 \\
\hline$A I^{n v}$ & 0,000 & 0,022 & 0,196 \\
\hline Soma-T & 8,103 & 8,000 & 8,000 \\
\hline $\mathrm{Al}^{\mathrm{YH}}$ & $\begin{array}{ll}0 & 0\end{array}$ & $\begin{array}{l}0,129 \\
0,129\end{array}$ & 0 \\
\hline$T_{\mathbf{i}}$ & 0,078 & 0,120 & 0,080 \\
\hline$Z x$ & 0,045 & 0,092 & 0,012 \\
\hline $\mathrm{Fe}^{3+2}$ & 0,974 & 1,005 & 1,141 \\
\hline $\mathrm{Mg}$ & 0,000 & 0,000 & 0,011 \\
\hline $\mathrm{Zn}$ & 0,129 & 0,151 & 0,073 \\
\hline $\mathrm{Fe}^{2+}$ & 3,178 & 2,921 & 3,612 \\
\hline $\mathbf{M} \mathbf{p}$ & 0,400 & 0,577 & 0,070 \\
\hline Soma $-C$ & 4,897 & 5,000 & 5,000 \\
\hline $\mathrm{Mg}$ & 0,000 & 0,000 & 0,000 \\
\hline $\mathrm{Zn}$ & 0,000 & 0,000 & 0,000 \\
\hline $\mathrm{Fe}^{2+}$ & 0,000 & 0,000 & 0,000 \\
\hline $\mathrm{Mn}$ & 0,000 & 0,000 & 0,067 \\
\hline $\mathrm{Ca}$ & 0,008 & 0,003 & 0,323 \\
\hline $\mathrm{Na}$ & 1,992 & 1,997 & 1,610 \\
\hline Soma-B & 2,000 & 2,000 & 2,000 \\
\hline $\mathrm{Na}$ & 0,144 & 0,239 & 0,294 \\
\hline $\mathbf{K}$ & 0,329 & 0,222 & 0,188 \\
\hline Soma-A & 0,473 & 0,461 & 0,482 \\
\hline Cátions & 15,473 & 15,461 & 15,482 \\
\hline$m g \#$ & 0,000 & 0,001 & 0,003 \\
\hline
\end{tabular}

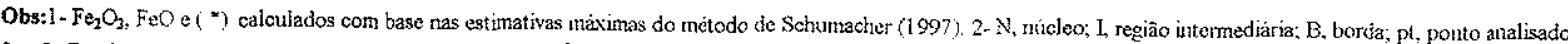

3-<L. D.: abaixo do limite de deteç̧ão. $4-\mathrm{mg}$ 
Tabela V.4. Análises químicas (WDS) e fórmulas estruturais de biotita das rochas do Maciço Corupá.

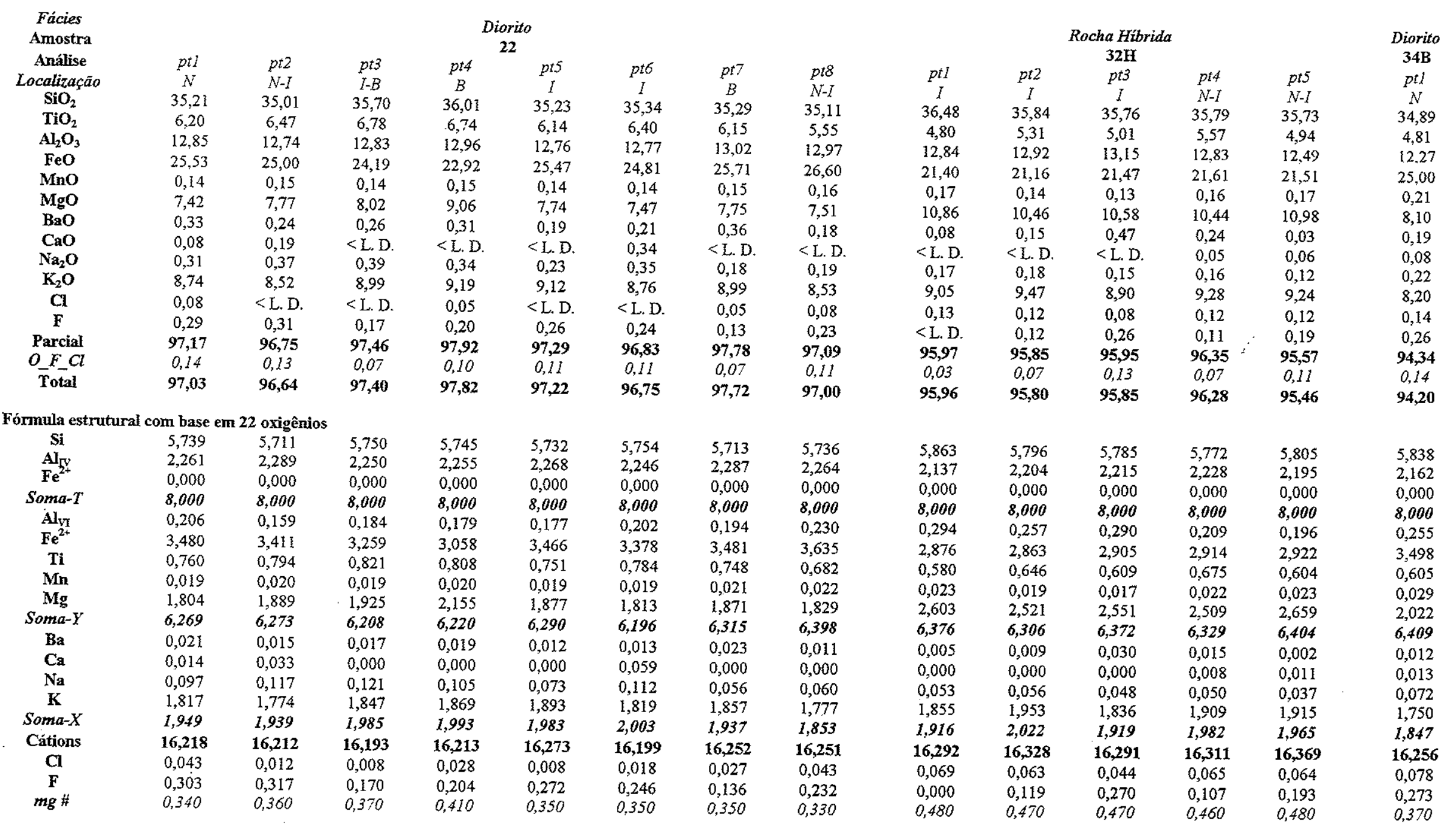

Obs: $1-N$, núcleo; $I$, região intermediária; $B$, borda: pt, ponto anlisado.

2-< L. D.: abaixo do limite de deteç̧ão.

3- $\mathrm{mg} \#=\mathrm{Mg} /\left(\mathrm{Mg}+\mathrm{Fe}^{2+}\right)$. 
Tabela V.4. Continuação.

\begin{tabular}{|c|c|c|c|c|c|c|c|c|c|c|c|c|}
\hline \multirow{2}{*}{$\begin{array}{c}\text { Fácies } \\
\text { Amostra } \\
\text { Análise }\end{array}$} & \multicolumn{8}{|c|}{$\begin{array}{l}\text { Rocha Híbrida } \\
\text { 34B }\end{array}$} & \multicolumn{4}{|c|}{$\begin{array}{l}\text { Rocha Hibrida } \\
\text { 4D }\end{array}$} \\
\hline & pt2 & $p t 3$ & $p^{t 4}$ & $p t 5$ & pt6 & $p t 7$ & $p t 8$ & $p t 9$ & $p t 2$ & $p t 3$ & $p t 4$ & pts \\
\hline Localizaçäo & I & $I$ & $B$ & $B$ & $B$ & $B$ & $B$ & $I-B$ & $I$ & $B$ & $I$ & $I-B$ \\
\hline $\mathrm{SiO}_{2}$ & & 34,63 & 34,68 & 34,67 & 35,47 & 35,16 & 35,53 & 35,35 & 35,90 & 35,36 & 35,54 & 35,76 \\
\hline $\mathrm{TiO}_{2}$ & 5,38 & 5,82 & 5,25 & 5,26 & 5,47 & 5,31 & 4,71 & 5,31 & 6,70 & 5,88 & 6,18 & 6,47 \\
\hline $\mathrm{Al}_{2} \mathrm{O}_{3}$ & 12,06 & 12,21 & 12,33 & 12,32 & 11,99 & 12,14 & 12,30 & 12,24 & 12,81 & 12,67 & 12,81 & 12,83 \\
\hline $\mathrm{FeO}$ & 25,05 & 24,31 & 25,59 & 25,56 & 24,50 & 24,64 & 25,15 & 25,57 & 21,97 & 24,08 & 22,73 & 22,84 \\
\hline Mno & 0,18 & 0,14 & 0,19 & 0,19 & 0,18 & 0,19 & 0,19 & 0,19 & 0,14 & 0,07 & 0,14 & 0,06 \\
\hline MgO & 8,40 & 7,81 & 7,92 & 7,92 & 8,06 & 8,20 & 8,44 & 7,93 & 9,58 & 8,20 & 9,84 & 9,00 \\
\hline $\mathrm{BaO}$ & 0,29 & 0,32 & 0,28 & 0,29 & 0,30 & 0,40 & 0,25 & 0,29 & 1,19 & 0,98 & 0,85 & 1,35 \\
\hline $\mathrm{CaO}$ & < L. D. & 0,55 & 0,06 & 0,06 & <L. D. & <L.D. & 0,05 & 0,06 & <L. D. & $<\mathrm{L} . \mathrm{D}$. & <L. D. & $<$ L. D. \\
\hline $\mathrm{Na}_{2} \mathrm{O}$ & 0,25 & 0,28 & 0,23 & 0,23 & 0,24 & 0,31 & 0,20 & 0,23 & 0,50 & 0,30 & 0,34 & 0,39 \\
\hline $\mathrm{K}_{2} \mathrm{O}$ & 8,90 & 8,67 & 8,45 & 8,55 & 9,07 & 8,92 & 8,60 & 8,55 & 8,83 & 8,89 & 8,86 & 8,99 \\
\hline $\mathrm{C}$ & 0,13 & 0,11 & 0,12 & 0,12 & 0,07 & 0,08 & 0,16 & 0,12 & <L. D. & 0,05 & <L. D. & <L. D. \\
\hline $\mathbf{F}$ & 0,41 & 0,57 & 0,38 & 0,38 & 0,52 & 0,44 & 0,64 & 0,38 & 0,49 & 0,33 & 0,41 & 0,35 \\
\hline Parcial & 96,41 & 95,41 & 95,47 & 95,54 & 95,88 & 95,79 & 96,21 & 96,22 & 98,08 & 96,80 & 97,69 & 98,04 \\
\hline$O_{-} F_{-} C l$ & 0,20 & 0,26 & 0,19 & 0,19 & 0,24 & 0,21 & 0,30 & 0,19 & 0,21 & 0,15 & 0,18 & 0,15 \\
\hline Total & 96,23 & 95,15 & 95,28 & 95,35 & 95,64 & 95,63 & 95,91 & 96,03 & 97,90 & 96,66 & 97,57 & 97,92 \\
\hline \multicolumn{13}{|c|}{$\begin{array}{c}\text { órmula estrutural com base em } 22 \text { oxigênios } \\
\mathrm{Si}\end{array}$} \\
\hline Si & 5,818 & 5,762 & 5,771 & 5,769 & 5,861 & 5,820 & 6,081 & 5,826 & 5,739 & 5,778 & 5,710 & 5,746 \\
\hline $\mathrm{Al}_{\mathrm{jy}}$ & 2,182 & 2,238 & 2,229 & 2,231 & 2,139 & 2,180 & 1,919 & 2,174 & 2,261 & 2,222 & 2,290 & 2,254 \\
\hline $\mathrm{Fe}^{2+}$ & 0,000 & 0,000 & 0,000 & 0,000 & 0,000 & 0,000 & 0,000 & 0,000 & 0,000 & 0,000 & 0,000 & 0,000 \\
\hline Soma-T & 8,000 & 8,000 & 8,000 & 8,000 & 8,000 & 8,000 & 8,000 & 8,000 & 8,000 & 8,000 & 8,000 & 8,000 \\
\hline $\mathbf{A} \mathbf{I}_{\mathrm{yl}}$ & 0,154 & 0,155 & 0,187 & 0,184 & 0,195 & 0,187 & 0,560 & 0,201 & 0,150 & 0,216 & 0,134 & 0,173 \\
\hline $\mathrm{Fe}^{2+}$ & 3,446 & 3,384 & 3,561 & 3,557 & 3,386 & 3,411 & 3,599 & 3,524 & 2,937 & 3,291 & 3,054 & 3,069 \\
\hline $\mathbf{T i}$ & 0,666 & 0,728 & 0,658 & 0,658 & 0,680 & 0,661 & 0,606 & 0,658 & 0,805 & 0,723 & 0,747 & 0,782 \\
\hline Mn & 0,025 & 0,020 & 0,026 & 0,026 & 0,025 & 0,026 & 0,028 & 0,026 & 0,019 & 0,010 & 0,019 & 0,009 \\
\hline $\mathbf{M g}$ & 2,059 & 1,938 & 1,965 & 1,965 & 1,985 & 2,023 & 2,153 & 1,949 & 2,282 & 1,997 & 2,355 & 2,156 \\
\hline Soma- $Y$ & 6,350 & 6,225 & 6,397 & 6,390 & 6,271 & 6,308 & 6,946 & 6,358 & 6,193 & 6,237 & 6,309 & 6,189 \\
\hline $\mathbf{B a}$ & 0,019 & 0,021 & 0,019 & 0,019 & 0,019 & 0,026 & 0,017 & 0,019 & 0,074 & 0,063 & 0,053 & 0,085 \\
\hline $\mathrm{Ca}$ & 0,004 & 0,097 & 0,010 & 0,010 & 0,001 & 0,008 & 0,009 & 0,010 & 0,001 & 0,001 & 0,004 & 0,000 \\
\hline $\mathrm{Na}$ & 0,079 & 0,089 & 0,074 & 0,074 & 0,078 & 0,098 & 0,067 & 0,073 & 0,153 & 0,095 & 0,106 & 0,121 \\
\hline $\mathbf{K}$ & 1,868 & 1,841 & 1,794 & 1,815 & 1,911 & 1,884 & 1,816 & 1,798 & 1,802 & 1,853 & 1,815 & 1,843 \\
\hline Soma-X & 1,970 & 2,048 & 1,897 & 1,918 & 2,009 & 2,016 & 1,909 & 1,900 & 2,030 & 2,012 & 1,978 & 2,049 \\
\hline Cátions & 100,000 & 16,273 & 16,294 & 16,308 & 16,280 & 16,324 & 15,170 & 16,258 & 16,223 & 16,249 & 16,287 & 16,238 \\
\hline Cl & 0,070 & 0,060 & 0,068 & 0,068 & 0,041 & 0,046 & 0,091 & 0,068 & 0,012 & 0,029 & 0,018 & 0,015 \\
\hline $\mathbf{F}$ & 0,429 & 0,602 & 0,395 & 0,395 & 0,545 & 0,465 & 0,688 & 0,392 & 0,499 & 0,344 & 0,412 & 0,357 \\
\hline$m g \#$ & 0,370 & 0,360 & 0,360 & 0,360 & 0,370 & 0,370 & 0,370 & 0,360 & 0,440 & 0,380 & 0,440 & 0,410 \\
\hline
\end{tabular}

Obs: 1- N, núcleo; I, região intermediária; $B$, borda; pt, ponto anlisâdo.

$2-<$ L. D.: abaixo do limite de detecção.

3. $\mathrm{mg} \#=\mathrm{Mg} /\left(\mathrm{Mg}+\mathrm{Fe}^{2+}\right)$. 
Tabela V.4. Continuação.

\begin{tabular}{|c|c|c|c|c|c|c|c|c|c|c|c|c|}
\hline \multirow{2}{*}{$\begin{array}{l}\text { Fácies } \\
\text { Amostra } \\
\text { Análise }\end{array}$} & \multicolumn{6}{|c|}{$\begin{array}{c}\text { Diorito } \\
\mathbf{5 0 \mathrm { B }}\end{array}$} & \multicolumn{6}{|c|}{$\begin{array}{l}\text { Enclave monzonítico } \\
\qquad 6 \mathrm{C}\end{array}$} \\
\hline & ptl & $p t 2$ & $p t 3$ & $p t 4$ & pt5 & $p t 6$ & $p t I$ & $p t 2$ & pt3 & $p t 4$ & pt5 & $p t 7$ \\
\hline Localização & $I-B$ & $B$ & $B$ & $N$ & $l-B$ & $I-B$ & $B$ & $B$ & $I$ & $B$ & $I-B$ & $t-B$ \\
\hline $\mathrm{SiO}_{2}$ & 36,41 & 36,24 & 36,01 & 35,55 & 36,02 & 35,84 & 36,44 & 36,67 & 35,91 & 36,35 & 36,76 & 36,10 \\
\hline $\mathrm{TiO}_{2}$ & 4,67 & 4,58 & 4,26 & 4,65 & 5,16 & 3,96 & 5,42 & 5,25 & 5,46 & 3,70 & 5,59 & 5,80 \\
\hline $\mathrm{Al}_{2} \mathrm{O}_{3}$ & 13,61 & 13,39 & 13,59 & 13,58 & 13,35 & 13,84 & 13,26 & 12,30 & 12,19 & 11,85 & 12,19 & 12,24 \\
\hline $\mathrm{FeO}$ & 18,73 & 18,47 & 18,83 & 18,78 & 18,59 & 18,39 & 23,53 & 23,32 & 25,93 & 27,86 & 23,82 & 22,98 \\
\hline Mno & 0,08 & 0,11 & 0,12 & 0,10 & 0,12 & 0,08 & 0,16 & 0,18 & 0,18 & 0,21 & 0,14 & 0,13 \\
\hline MgO & 13,13 & 13,01 & 13,52 & 13,10 & 12,68 & 13,25 & 9,45 & 9,70 & 9,05 & 7,73 & 9,63 & 9,81 \\
\hline $\mathrm{BaO}$ & 0,89 & 0,63 & 0,46 & 1,47 & 1,56 & 1,23 & $<$ L. D. & 0,15 & 0,16 & 0,10 & 0,17 & 0,07 \\
\hline $\mathrm{CaO}$ & <L. D. & 0,17 & 0,12 & <L. D. & 0,14 & 0,05 & <L. D. & $<$ L. D. & <L. D. & 0,06 & $<\mathrm{L} . \mathrm{D}$. & <L. D. \\
\hline $\mathrm{Na}_{2} \mathrm{O}$ & 0,33 & 0,32 & 0,30 & 0,28 & 0,29 & 0,33 & 0,24 & 0,38 & 0,33 & 0,17 & 0,48 & 0,38 \\
\hline $\mathrm{K}_{2} \mathrm{O}$ & 8,26 & 8,75 & 7,53 & 8,00 & 8,38 & 8,21 & 9,12 & 9,32 & 8,67 & 8,98 & 9,22 & 9,32 \\
\hline $\mathrm{Cl}$ & 0,06 & <L.D. & 0,05 & 0,07 & 0,07 & 0,08 & 0,13 & <L. D. & 0,05 & 0,71 & 0,06 & 0,05 \\
\hline $\mathrm{F}$ & 0,31 & 0,20 & 0,29 & 0,39 & 0,25 & 0,26 & 0,53 & 0,53 & 0,41 & 0,49 & 0,74 & 0,61 \\
\hline Parcial & 96,48 & 95,86 & 95,07 & 95,97 & 96,61 & 95,48 & 98,26 & 97,80 & 98,35 & 98,19 & 98,79 & 97,47 \\
\hline$O_{-} F_{-} C l$ & 0,15 & 0,09 & 0,13 & 0,18 & 0,12 & 0,12 & 0,25 & 0,23 & 0,18 & 0,36 & 0,33 & 0.27 \\
\hline Total & 96,35 & 95,81 & 94,94 & 95,79 & 96,49 & 95,36 & 98,01 & 97,60 & 98,20 & 97,83 & 98,46 & 97,20 \\
\hline \multicolumn{13}{|c|}{ Fórmula estrutural com base em 22 oxigênios } \\
\hline $\mathrm{Si}$ & 5,768 & 5,777 & 5,758 & 5,702 & 5,739 & 5,750 & 5,804 & 5,878 & 5,781 & 5,963 & 5,859 & 5,812 \\
\hline $\mathbf{A l}_{\mathrm{ly}}$ & 2,232 & 2,223 & 2,242 & 2,298 & 2,261 & 2,250 & 2,196 & 2,122 & 2,219 & 2,037 & 2,141 & 2,188 \\
\hline $\mathrm{Fe}^{2+}$ & 0,000 & 0,000 & 0,000 & 0,000 & 0,000 & 0,000 & 0,000 & 0,000 & 0,000 & 0,000 & 0,000 & 0,000 \\
\hline Soma- $T$ & 8,000 & 8,000 & 8,000 & 8,000 & 8,000 & 8,000 & 8,000 & 8,000 & 8,000 & 8,000 & 8,000 & 8,000 \\
\hline $\mathbf{A l}_{\mathrm{YI}}$ & 0,307 & 0,290 & 0,317 & 0,267 & 0,245 & 0,364 & 0,290 & 0,200 & 0,093 & 0,252 & 0,147 & 0,133 \\
\hline $\mathrm{Fe}^{2+}$ & 2,481 & 2,462 & 2,517 & 2,520 & 2,477 & 2,467 & 3,134 & 3,127 & 3,491 & 3,822 & 3,175 & 3,095 \\
\hline $\mathrm{Ti}$ & 0,556 & 0,549 & 0,512 & 0,561 & 0,619 & 0,478 & 0,649 & 0,634 & 0,661 & 0,456 & 0,670 & 0,703 \\
\hline Mn & 0,011 & 0,015 & 0,017 & 0,013 & 0,016 & 0,010 & 0,021 & 0,024 & 0,025 & 0,029 & 0,019 & 0,018 \\
\hline $\mathbf{M g}$ & 3,101 & 3,091 & 3,221 & 3,132 & 3,013 & 3,168 & 2,243 & 2,317 & 2,172 & 1,889 & 2,289 & 2,354 \\
\hline Soma-Y & 6,456 & 6.407 & 6,584 & 6,493 & 6,370 & 6,487 & 6,337 & 6,302 & 6,442 & 6,448 & 6,300 & 6.303 \\
\hline $\mathrm{Ba}$ & 0,055 & 0,039 & 0,029 & 0,092 & 0,097 & 0,077 & 0,000 & 0,009 & 0,010 & 0,006 & 0,011 & 0,004 \\
\hline $\mathrm{Ca}$ & 0,000 & 0,029 & 0,020 & 0,000 & 0,024 & 0,008 & 0,000 & 0,000 & 0,000 & 0,011 & 0,000 & 0,000 \\
\hline $\mathrm{Na}$ & 0,102 & 0,100 & 0,093 & 0,087 & 0,090 & 0,102 & 0,074 & 0,118 & 0,103 & 0,055 & 0,148 & 0,118 \\
\hline $\mathbf{K}$ & 1,670 & 1,778 & 1,535 & 1,638 & 1,704 & 1,680 & 1,853 & 1,907 & 1,780 & 1,878 & 1,874 & 1,914 \\
\hline Soma-X & 1,830 & 1,946 & 1,677 & 1,817 & 1,915 & 1,867 & 1,927 & 2,034 & 1,899 & 1,950 & 2,033 & 2,036 \\
\hline Cátions & 16,286 & 16,353 & 16,261 & 16,310 & 16,285 & 16,354 & 16,264 & 16,336 & 16,341 & 16,398 & 16,333 & 16,339 \\
\hline $\mathrm{Cl}$ & 0,034 & 0,024 & 0,025 & 0,038 & 0,038 & 0,041 & 0,068 & 0,017 & 0,028 & 0,393 & 0,034 & 0,026 \\
\hline $\mathrm{F}$ & 0,315 & 0,203 & 0,293 & 0,392 & 0,248 & 0,260 & 0,534 & 0,536 & 0,415 & 0,504 & 0,748 & 0,623 \\
\hline$m g \#$ & 0.560 & 0,560 & 0,560 & 0.550 & 0,550 & 0,560 & 0,420 & 0,430 & 0,380 & 0,330 & 0,420 & 0.430 \\
\hline
\end{tabular}

Obs: $1 \cdot \mathrm{N}$, núcleo; $\mathrm{I}$, região intermediária; $\mathrm{B}$, borda; pt, ponto anlisado.

$2-<$ L. D.: abaixo do limite de detecção.

3- $\mathrm{mg} \#=\mathrm{Mg}\left(\mathrm{Mg}^{2}+\mathrm{Fe}^{2+}\right)$. 
Tabela V.4. Continuação

\begin{tabular}{|c|c|c|c|c|}
\hline \multirow{3}{*}{$\begin{array}{l}\text { Fácies } \\
\text { Amostra } \\
\text { Análise }\end{array}$} & \multirow{2}{*}{\multicolumn{4}{|c|}{ Melasienito }} \\
\hline & \multicolumn{2}{|c|}{ 32D } & & \\
\hline & ptl & $p t 2$ & $p t^{3}$ & pt4 \\
\hline Localizaçāo & $I-B$ & $I-B$ & $B$ & $N$ \\
\hline $\mathrm{SiO}_{2}$ & 36,09 & 36,32 & 36,11 & 35,50 \\
\hline $\mathrm{TiO}_{2}$ & 4,61 & 4,79 & 4,52 & 4,91 \\
\hline $\mathrm{Al}_{2} \mathrm{O}_{3}$ & 12,13 & 12,41 & 12,17 & 11,94 \\
\hline $\mathrm{FeO}$ & 27,26 & 26,11 & 25,96 & 27,10 \\
\hline Mno & 0,12 & 0,16 & 0,17 & 0,19 \\
\hline MgO & 7,72 & 8,00 & 8,57 & 7,57 \\
\hline $\mathrm{BaO}$ & 0,08 & $<$ L. D. & $<$ L. D. & <L. D. \\
\hline $\mathrm{CaO}$ & 0,06 & 0,05 & 0,19 & 0,14 \\
\hline $\mathrm{Na}_{2} \mathrm{O}$ & 0,21 & 0,26 & 0,20 & 0,23 \\
\hline $\mathrm{K}_{2} \mathrm{O}$ & 8,90 & 9,18 & 8,20 & 8,78 \\
\hline $\mathrm{Cl}$ & $<$ L. D. & 0,06 & 0,05 & $<$ L. D \\
\hline $\mathbf{F}$ & 0,17 & 0,05 & 0,18 & 0,06 \\
\hline Parcial & 97,35 & 97,38 & 96,31 & 96,41 \\
\hline$O_{-} F_{-} C l$ & 0,08 & 0,03 & 0,09 & 0,03 \\
\hline $\overrightarrow{\text { Total }}$ & 97,30 & 97,39 & 96,22 & 96,42 \\
\hline \multicolumn{5}{|c|}{ ormula estrutural com base em 22 oxigênios } \\
\hline $\mathrm{Si}$ & 5,890 & 5,889 & 5,898 & 5,850 \\
\hline $\mathbf{A l}_{\mathrm{By}}$ & 2,110 & 2,111 & 2,102 & 2,150 \\
\hline $\mathrm{Fe}^{2+}$ & 0,000 & 0,000 & 0,000 & 0,000 \\
\hline Soma-T & 8,000 & 8,000 & 8,000 & 8,000 \\
\hline $\mathbf{A l}_{\mathrm{y}}$ & 0,220 & 0,258 & 0,240 & 0,167 \\
\hline $\mathrm{Fe}^{2+}$ & 3,721 & 3,540 & 3,546 & 3,735 \\
\hline $\mathbf{T i}$ & 0,566 & 0,584 & 0,555 & 0,608 \\
\hline Mn & 0,017 & 0,022 & 0,024 & 0,026 \\
\hline $\mathbf{M g}$ & 1,877 & 1,934 & 2,087 & 1,859 \\
\hline Soma- $Y$ & 6,401 & 6,338 & 6,452 & 6,395 \\
\hline $\mathbf{B a}$ & 0,005 & 0,000 & 0,000 & 0,000 \\
\hline $\mathrm{Ca}$ & 0,010 & 0,008 & 0,033 & 0,025 \\
\hline $\mathrm{Na}$ & 0,065 & 0,082 & 0,064 & 0,074 \\
\hline $\mathrm{K}$ & 1,854 & 1,899 & 1,708 & 1,846 \\
\hline Soma-X & 1,934 & 1,992 & 1,805 & 1,945 \\
\hline Cátions & 16,335 & 16,330 & 16,257 & 16,340 \\
\hline $\mathrm{Cl}$ & 0,017 & 0,031 & 0,026 & 0,018 \\
\hline $\mathbf{F}$ & 0,178 & 0,047 & 0,188 & 0,067 \\
\hline$m g \#$ & 0,340 & 0.350 & 0370 & \\
\hline
\end{tabular}

Obs: $1-\mathrm{N}$, núcleo; I, região intermediária; $\mathrm{B}$, borda; pt, ponto anlisado. 2- < L. D.: abaixo do limite de detecção.

$3-\mathrm{mg} \#=\mathrm{Mg} /\left(\mathrm{Mg} \div \mathrm{Fe}^{2+}\right)$. 
Tabela V.5. Análises quimicas (WDS) e fórmulas estruturais de plagioclásio das rochas dioriticas do Maciço Conupá

Fácies

Anostra

Análise
Localizaçăo

$\begin{array}{ccc}\text { Análise } & p t 1 & p t 2 \\ \text { Localizaçăa } & N & N \\ \text { SiO2 } & 57,01 & 56,53 \\ \mathrm{TiO} 2 & 0,14 & 0,10\end{array}$

$\mathrm{Al} 2 \mathrm{O3}$

$\mathrm{Fe} 2 \mathrm{O} 3$

MnO

$\mathrm{MgO}$

$\mathrm{CaO}$

Sro

$\mathrm{BaO}$

K20

Total

57,01
0,14
27,39
0,14

$56,53 \quad 56,92$

26,81

$0,14 \quad 0,17$

L.D.

$<$ L. D. $<$ L. D.

0,12

0,13

$6,20 \quad 6,36$

0,27

$9,00 \quad 9,03$

$0,13 \quad 0,09$

6,36

100,43

99,43

Fórmula estrutural com base em 32 oxigênios

$\begin{array}{llll}\mathrm{Si} & 10,204 & 10,224 & 10,230\end{array}$

$\begin{array}{ccc}\mathrm{Si} & 10,204 & 10,224 \\ \mathrm{Al} & 5,772 & 5,711 \\ \mathrm{Fe}^{3+} & 0,019 & 0,024 \\ \text { Sama-T } & 15,995 & 15,959\end{array}$

Soma-T $\quad 15,995 \quad 15,959$

$\begin{array}{ccc}\text { Ti } & 0,019 & 0,013 \\ \mathbf{M n} & 0,000 & 0,000 \\ \mathbf{M g} & 0,000 & 0,000\end{array}$

$\begin{array}{lll}\mathbf{M g} & 0,000 & 0,000 \\ \mathbf{B a} & 0,009 & 0,000 \\ \mathbf{C a} & 1,732 & 1,745 \\ \mathbf{N a} & 2,150 & 2,229 .\end{array}$

$\begin{array}{lll}\mathrm{Ca} & 1,732 & 1,745 \\ \mathrm{Na} & 2,150 & 2,229 \\ \mathrm{Sr} & 0,013 & 0,014 \\ \mathrm{~K} & 0,061 & 0,068\end{array}$

$\begin{array}{ccc}\text { Soma-M } & 0,061 & 0,068 \\ \text { Cátions } & 3,985 & \mathbf{4 , 0 7 6} \\ & \mathbf{1 9 , 9 8 0} & \mathbf{2 0 , 0 3 5}\end{array}$

Componentes moleculares

Obs: I- $\mathrm{Fe}_{\text {total }}$ calculado como $\mathrm{Fe}^{3+}$

2- N, núcleo grão; I, regiâo intermediária grão; $B$, borda grão; pt, ponto analisado.

3. <L. D.: abaixo do índice de deteccāo.

$\begin{array}{cccc}p t 4 & p t 5 & p t 6 & p t 7 \\ N & N-I & N-I & N-I \\ 56,80 & 56,39 & 62,86 & 62,89\end{array}$

(100,36

$\begin{array}{lllll}5,740 & 5,663 & 5,848 & 4,820 & 4,777\end{array}$

$0,019 \quad 0,024$

$0,019 \quad 0,032$

$\begin{array}{ccccc}15,989 & 15,980 & 15,999 & 15,995 & 15,972 \\ 0,010 & 0,021 & 0,012 & 0,008 & 0,008 \\ 0,000 & 0,000 & 0,000 & 0,000 & 0,000\end{array}$

$\begin{array}{llll}0,000 & 0,000 & 0,000 & 0,000\end{array}$

\begin{tabular}{|c|c|c|c|c|c|c|c|c|c|c|c|c|c|c|c|c|}
\hline $\mathbf{A b}$ & 54,5 & 55,1 & 54,5 & 55,1 & 53,0 & 73,5 & 73,6 & 75,5 & 74,9 & 75,2 & 74,8 & 73,8 & 74,8 & 75,5 & 78,1 & 78,0 \\
\hline An & 43,9 & 43,2 & 43,6 & 43,2 & 45,6 & 22,5 & 21,2 & 20,0 & 20,6 & 22,3 & 22,1 & 22,5 & 21,8 & 21,4 & 19,3 & 20,3 \\
\hline Or & 1,5 & 1,7 & 1,8 & 1,7 & 1,4 & 4,0 & 5,2 & 4,5 & 4,5 & 2,5 & 3,0 & 3,7 & 3,5 & 3,1 & 2,6 & 1,7 \\
\hline
\end{tabular}

Diorito

pt8 $\quad p t s$

63,81 62,94

$\begin{array}{rl}<\text { L. D. } & <\text { L. D. } \\ 22,69 & 22,68\end{array}$

22.83

0,14

$<$ L. D.

$0,15 \quad 0,20$

$\begin{aligned} 0,08 & <\text { L. D. } \\ <\text { L. D. } & <\text { L. D }\end{aligned}$

4,12 4,19

$0,09 \quad<$ L. D. $\quad 0,10$

8,41

0,39

8,59

100,64

0,26
8,42

8,42
0,77

$\mathbf{9 9 , 5 8}$

ptio
$I$
6232

62,32
0,05

0,05
22,93

0,18

$<$ L. D.

4,69

4,69
0,12
0,08

0,08

8,75

0,45
$\mathbf{9 9 , 5 6}$

ptll
$I$

63,20
<L. D.

$\begin{array}{cc}\text { pt12 } & p t 13 \\ I & I-B \\ 63,30 & 62,88\end{array}$

63,30
<L. D. $\quad$ L. D.

$23.24 \quad 23,18 \quad 23.06$

<L. D. <L. D. < L D.

L L. D. $\quad$ L. D. <L. D.

$4,63 \quad 4,67 \quad 4,50$

0,10

$<$ L. D.

0,10
0,10
8,55

8,64

0,53
$\mathbf{1 0 0 , 5 9}$

$8,49 \quad 8,55$

$\begin{array}{cc}0,64 & 0,60 \\ 100,69 & \mathbf{1 0 0 , 0 4}\end{array}$

ptlt ptls ptlo

$63,17 \quad 62,95 \quad 63.51$

$0,07 \quad 0,05 \quad<$ L. D.

$23,00 \quad 22.40 \quad 22,86$

<L. D < L D < < D.

<L. D. $\quad 0,34 \quad$ L L. D.

4,48 3,95 4,27

$0,09<$ L D. D.

$8,73 \quad 8,82 \quad 9,08$

$0,54 \quad 0,45 \quad 0,30$

$11,255 \quad 11,219$

11,119

11,144

$11,154 \quad 11,154$

$11,170 \quad 11,195 \quad 11,209$

$0,019 \quad 0,020 \quad 0,027$

15,972

15,988

0,027
16,006

$0,024 \quad 0,028$

$\begin{array}{cc}0,024 & 0,028 \\ 15,961 & 15,997\end{array}$

4,811

4,816

$\begin{array}{ccc}11,170 & 11,195 & 11,209 \\ 4,789 & 4,691 & 4,752\end{array}$

$0,005 \quad 0,000$

0,007

0,000

$\begin{array}{cc}0,028 & 0,030 \\ 15,993 & 16,000\end{array}$

$0,023 \quad 0,083 \quad 0,020$

$15,982 \quad 15,969 \quad 15,981$

$0,010 \quad 0,006 \quad 0,001$

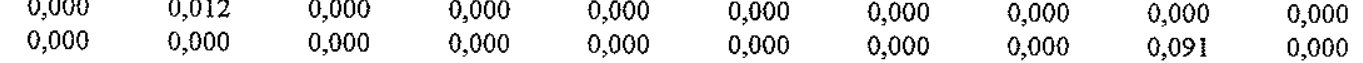

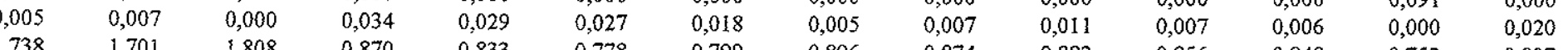

$\begin{array}{llllllllllllll}2,172 & 2,169 & 2,098 & 2,842 & 2,897 & 2,939 & 2,910 & 3,027 & 2,954 & 2,900 & 2,942 & 0,848 & 0,752 & 0,807 \\ 0,009 & 0,097 & 0,015 & 0,009 & 0,009 & 0,000 & 0,010 & 0,012 & 0,000 & 0,000 & 0,010 & 0,003 & 0,007 & 0,000\end{array}$

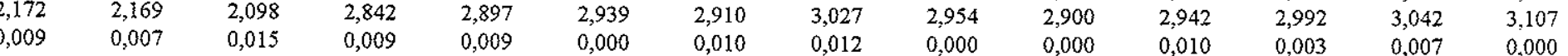

$\begin{array}{llllllllllllll}0,072 & 0,066 & 0,056 & 0,154 & 0,204 & 0,000 & 0,010 & 0,012 & 0,000 & 0,000 & 0,010 & 0,003 & 0,007 & 0,000 \\ & 3,92 & 3,95 & 3,919 & 3,991 & 3,936 & 0,174 & 0,102 & 0,119 & 0,145 & 0,136 & 0,121 & 0,103 & 0,068\end{array}$

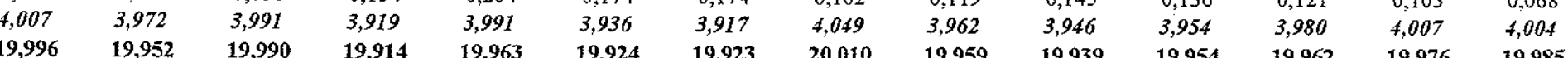


Tabela V.5. Continuação

\begin{tabular}{|c|c|c|c|c|}
\hline Fácies & & & & \\
\hline Amostra & & & & \\
\hline & $p t / 7$ & pt18 & pt19 & $p t 20$ \\
\hline Localização & $B$ & $B$ & $B$ & $B$ \\
\hline $\mathrm{SiO} 2$ & 63,22 & 63,75 & 65,45 & 63,67 \\
\hline TiO2 & $<\mathrm{L} . \mathrm{D}$. & $<$ L. D. & < L. D. & $<$ L. D. \\
\hline $\mathrm{Al} 2 \mathrm{O3}$ & 22,84 & 22,56 & 21,70 & 22,37 \\
\hline $\mathrm{Fe} 2 \mathrm{O3}$ & 0,14 & 0,16 & 0,24 & 0,19 \\
\hline MnO & 0,05 & < L. D. & <L.D. & <L. D. \\
\hline $\mathrm{MgO}$ & <L. D. & $<$ L. D. & <L. D. & $<\mathrm{L} . \mathrm{D}$. \\
\hline $\mathrm{CaO}$ & 4,21 & 4,06 & 3,02 & 3,90 \\
\hline Sro & <L. D. & <L. D. & $<\mathrm{L} . \mathrm{D}$. & 0,09 \\
\hline $\mathrm{BaO}$ & 0,19 & 0,10 & 0,22 & 0,19 \\
\hline $\mathrm{Na} 2 \mathrm{O}$ & 8,87 & 9,00 & 9,53 & 9,14 \\
\hline $\mathrm{K} 2 \mathrm{O}$ & 0,43 & 0,40 & 0,42 & 0,23 \\
\hline Total & 100,01 & 100,06 & 100,64 & 99,81 \\
\hline
\end{tabular}

$\begin{array}{ccccc}\text { Fórmula estrutural com base em } 32 \text { oxigênios } \\ \mathbf{S i} & 11,205 & 11,272 & 11,482 & 11,292 \\ \mathbf{A l} & 4,767 & 4,698 & 4,482 & 4,671 \\ \mathbf{F e} 3 & 0,019 & 0,022 & 0,032 & 0,025 \\ \text { Soma-T } & 15,991 & 15,992 & 15,996 & 15,988 \\ \mathbf{T i} & 0,002 & 0,000 & 0,000 & 0,000 \\ \mathbf{M n} & 0,008 & 0,000 & 0,000 & 0,000 \\ \mathbf{M g} & 0,000 & 0,000 & 0,000 & 0,000 \\ \mathbf{B a} & 0,013 & 0,007 & 0,015 & 0,013 \\ \mathbf{C a} & 0,799 & 0,769 & 0,567 & 0,741 \\ \mathbf{N a} & 3,048 & \mathbf{3 , 0 8 5} & 3,243 & 3,144 \\ \mathbf{S r} & 0,000 & 0,000 & 0,000 & 0,010 \\ \mathbf{K} & 0,097 & 0,091 & 0,094 & 0,051 \\ \text { Soma- } M & \mathbf{3 , 9 7 4} & \mathbf{3 , 9 5 6} & \mathbf{3 , 9 2 8} & \mathbf{3 , 9 6 4} \\ \text { Cátions } & \mathbf{1 9 , 9 6 5} & \mathbf{1 9 , 9 4 8} & \mathbf{1 9 , 9 2 4} & \mathbf{1 9 , 9 5 2}\end{array}$

Componentes moleculares

$\begin{array}{ccccc}\text { Ab } & 77,3 & 78,2 & 83,1 & 79,9 \\ \text { An } & 20,3 & 19,5 & 14,5 & 18,8 \\ \text { Or } & 2,5 & 2,3 & 2,4 & 1,3\end{array}$

Obs: 1- $\mathrm{Fe}_{\text {total }}$ calculado como $\mathrm{Fe}^{3 \div}$

2- N, núcleo grão; I, região intermediária grão; $B$, borda grão; pt, ponto analisado

3-< L. D.: abaixo do índice de detecção. 
Tabela V.6. Composição quimica primária estimada dos feldspatos alcalinos das rochas sieníticas e graniticas do Maciço Corupá

\begin{tabular}{|c|c|c|c|c|c|c|c|c|c|c|c|c|c|c|}
\hline \multirow{2}{*}{$\begin{array}{c}\text { Fácies } \\
\text { Amostra } \\
\text { Localizaçăo } \\
\mathrm{SiO}_{2}\end{array}$} & $N$ & $I$ & $B$ & $N$ & $B$ & \multicolumn{2}{|c|}{$\begin{array}{l}\text { Sienito Verde Grosso } \\
\text { 32C }\end{array}$} & \multicolumn{2}{|c|}{$\begin{array}{l}\text { Melasienito } \\
\text { 32D }\end{array}$} & \multicolumn{3}{|c|}{$\begin{array}{c}\text { Sienito Róseo Grosso } \\
\mathbf{5 1}\end{array}$} & \multicolumn{2}{|c|}{$\begin{array}{c}\text { Sienito Verde Médio } \\
5\end{array}$} \\
\hline & 65,87 & 66,28 & 65,87 & 66,90 & 66,27 & 65,47 & $\begin{array}{c}B \\
65,70\end{array}$ & $\begin{array}{c}N \\
65,18\end{array}$ & $B$ & $\begin{array}{c}N \\
6626\end{array}$ & $I$ & $B$ & $N$ & $B$ \\
\hline $\mathrm{MiO}_{2}$ & <L. D. & <L. D. & 0,09 & $<$ L. D. & $<$ L. D. & <L. D. & $\begin{array}{r}65,70 \\
<\mathrm{L} . \mathrm{D} .\end{array}$ & $\begin{array}{l}65,18 \\
<\text { L. D. }\end{array}$ & 65,49 & $\begin{array}{r}66,26 \\
<\mathrm{L} . \mathrm{D} .\end{array}$ & 65,96 & 66,29 & 66,90 & 66,96 \\
\hline $\mathrm{Al}_{2} \mathrm{O}_{3}$ & 39,07 & 19,87 & 18,75 & 19,31 & 18,53 & 18,82 & 19,15 & $\begin{array}{l}<\mathrm{L} . \mathrm{D} . \\
20,12\end{array}$ & <L.D. & $\begin{array}{l}<\mathrm{L} . \mathrm{D} . \\
18,91\end{array}$ & <L. D. & $<$ L. D. & <L. D. & <L. D. \\
\hline $\mathrm{Fe}_{2} \mathrm{O}_{3}$ & 0,11 & 0,13 & 0,32 & 0,13 & 0,07 & 1,23 & 0,85 & 0,13 & $\begin{array}{c}19,66 \\
0,17\end{array}$ & $\begin{array}{c}18,91 \\
0,19\end{array}$ & 18,80 & 19,29 & 19,15 & 18,52 \\
\hline MnO & $<$ L. D. & <L. D. & < L. D. & $<\mathrm{L} . \mathrm{D}$. & < L. D. & <L. D. & $<\mathrm{L}$. D. & <L. D. & 0,17 & $\begin{array}{r}0,19 \\
<\text { L. D. }\end{array}$ & 0,31 & 0,69 & 0,27 & 0,31 \\
\hline $\mathrm{MgO}$ & $<$ L. D. & <L. D. & <L. D. & <L. D. & <L. D. & <L. D. & $<\mathrm{L} . \mathrm{D}$. & <L. D. & $<$ L. D. & <L. D. & $<\mathrm{L} . \mathrm{D}$. & <L. D. & <L. D. & <L. D. \\
\hline $\mathrm{BaO}$ & 0,05 & 0,09 & 0,07 & 0,06 & $<$ L. D. & 0,14 & 0,10 & 0,40 & $\begin{array}{c}\text { <L. D. } \\
0.50\end{array}$ & <L. D. & <L. D. & <L. D. & <L. D. & <L.D. \\
\hline $\mathrm{CaO}$ & 0,44 & 0,99 & 0,23 & 0,22 & <L. D. & 0,27 & 0,65 & 1,49 & 0,50 & 0,12 & 0,18 & 0,16 & $<$ L. D. & <L. D. \\
\hline $\mathrm{Na}_{2} \mathrm{O}$ & 3,93 & 4,27 & 5,52 & 4,96 & 6,34 & 5,26 & 6,29 & 7,08 & 1,00 & 0,27 & 0,39 & 0,68 & 0,32 & 0,08 \\
\hline $\mathrm{K}_{2} \mathrm{O}$ & 9,76 & 8,10 & 8,56 & 7,92 & 7,70 & 8,79 & 7,13 & 5,33 & 6,08 & 5,40 & 4,85 & 4,89 & 6,68 & 6,30 \\
\hline Sro & <L. D. & <L. D. & <L.D. & $<$ L. D. & $<\mathrm{L} . \mathrm{D}$. & <L. D. & $<$ L. D. & $<\mathrm{L}$ D & 7,10 & 9,01 & 9,63 & 8,09 & 6,84 & 7,65 \\
\hline Total & 99,30 & 99,77 & 99,46 & 99,53 & 98,97 & 100,03 & 99,98 & $\begin{array}{l}\text { 2.D. } \\
99,79\end{array}$ & $\begin{array}{l}<\mathrm{L} . \mathrm{D} \text {. } \\
\mathbf{1 0 0 , 0 7}\end{array}$ & $\begin{array}{l}\text { <L. D. } \\
100.23\end{array}$ & $\begin{array}{l}<\mathrm{L} \text {. D. } \\
\mathbf{1 0 0 . 1 8}\end{array}$ & $\begin{array}{l}\text { <L. D. } \\
100.18\end{array}$ & <L.D. & $\begin{array}{l}<\text { L. D. } \\
99.91\end{array}$ \\
\hline \multirow{2}{*}{\multicolumn{15}{|c|}{$\begin{array}{l}\text { Fórmula estrutural corn base em } 32 \text { oxigênios. } \\
\mathrm{Si} \\
\mathrm{Si}\end{array}$}} \\
\hline $\mathrm{Si}$ & 11,920 & 11,813 & 11,942 & 11,945 & 12,016 & 11,857 & 11,828 & 11,708 & & & & & & \\
\hline Al & 4,062 & 4,169 & 4,002 & 4,059 & 3,956 & 4,013 & 4,060 & 4,254 & 4,169 & $\begin{array}{c}11,941 \\
4,014\end{array}$ & $\begin{array}{l}11,930 \\
4,003\end{array}$ & $\begin{array}{c}11,855 \\
4,062\end{array}$ & $\begin{array}{l}11,941 \\
4,025\end{array}$ & $\begin{array}{l}12,025 \\
3,916\end{array}$ \\
\hline $\begin{array}{c}\mathrm{Fe}^{3+} \\
\text { Soma- } T\end{array}$ & 0,015 & 0,017 & $\begin{array}{r}0,044 \\
15,988\end{array}$ & $\begin{array}{c}0,018 \\
16,023\end{array}$ & $\begin{array}{r}0,010 \\
15,982\end{array}$ & 0,166 & $\begin{array}{c}0,116 \\
16,005\end{array}$ & 0,018 & 0,023 & 0,026 & 0,042 & 0,094 & 0,036 & 0,043 \\
\hline $\begin{array}{l}\text { Soma- } T \\
\mathrm{Ti}\end{array}$ & 15,996 & 16,000 & & 16,023 & 15,982 & 16,035 & 16,005 & 15,979 & 15,985 & 15,980 & 15,975 & 16,011 & 16,002 & 15,983 \\
\hline $\begin{array}{c}\text { Ti } \\
\text { Mn }\end{array}$ & 0,000 & 0,000 & 0,012 & 0,000 & 0,000 & 0,000 & 0,000 & 0,000 & 0,000 & 0,000 & 0,000 & 0,000 & 0,000 & 0,000 \\
\hline Mn & 0,000 & 0,000 & 0,000 & 0,000 & 0,000 & 0,000 & 0,000 & 0,000 & 0,000 & 0,000 & 0,000 & 0,000 & 0,000 & 0,000 \\
\hline $\mathrm{Mg}$ & 0,000 & 0,000 & 0,000 & 0,000 & 0,000 & 0,000 & 0,000 & 0,000 & 0,000 & 0,000 & 0,000 & 0,000 & 0,000 & 0,000 \\
\hline $\mathbf{B a}$ & 0,004 & 0,007 & 0,005 & 0,005 & 0,000 & 0,010 & 0,007 & 0,029 & 0,035 & 0,008 & 0,013 & 0,012 & 0,000 & 0,000 \\
\hline $\mathrm{Ca}$ & 0,085 & 0,188 & 0,046 & 0,041 & 0,000 & 0,052 & 0,125 & 0,286 & 0,192 & 0,052 & 0,076 & 0,129 & 0,062 & 0,014 \\
\hline $\mathrm{Na}$ & 2,073 & 2,797 & $l, 932$ & 2,705 & 2,164 & 1,823 & 2,171 & 2,459 & 2,120 & 1,881 & 1,691 & 2,379 & 2,366 & 2,194 \\
\hline $\mathrm{K}$ & 1,803 & 0,974 & 1,986 & 1,169 & 1,845 & 2,055 & 1,663 & 1,231 & 1,634 & 2,079 & 2,232 & 1,401 & 1,522 & 1,753 \\
\hline $\mathrm{Sr}$ & 0,000 & 0,000 & 0,000 & 0,000 & 0,000 & 0,000 & 0,000 & 0,000 & 0,000 & 0,000 & 0,000 & 0,000 & 0,000 & 0,000 \\
\hline Soma-M & 3,972 & 3,971 & 3,988 & 3,922 & 4,017 & 3,951 & 3,985 & 4,012 & 3,992 & 4,029 & 4,026 & 3,936 & 3,960 & 3,974 \\
\hline Cátions & 19,968 & 19,970 & 19,976 & 19,945 & 19,998 & 19,986 & 19,990 & 19,991 & 19,977 & 20,010 & 20,001 & 19,947 & 19,962 & 19,958 \\
\hline \multirow{2}{*}{\multicolumn{15}{|c|}{$\begin{array}{c}\text { Componentes moleculares } \\
A b\end{array} 48,560$}} \\
\hline$A b$ & & 70,633 & 48,883 & 69,300 & 53,850 & 46,725 & 54,560 & 61,760 & 53,767 & 47,033 & 42,233 & 58,760 & 59,850 & 55,400 \\
\hline$A n$ & 2,150 & 4,767 & 1,133 & 1,050 & 0,000 & 1,325 & 3,120 & 7,160 & 4,900 & I,333 & 1,900 & 3,280 & 1,550 & 0,367 \\
\hline Or & 49,280 & 24,600 & 49,950 & 29,650 & 46,150 & 51,950 & 42,300 & 31,060 & 41,367 & 51,667 & 55,900 & 37,960 & 38,575 & 44,300 \\
\hline
\end{tabular}

Obs: $1-\mathrm{Fe}_{\text {total }}$ calculado como $\mathrm{Fe}^{3+}$.

2-N, núcleo grão; 1 , região intermediária grão; $B$, borda grão; pt, ponto analisado. 
Tabela V.6. Continuação

\begin{tabular}{|c|c|c|}
\hline \multirow{3}{*}{$\begin{array}{c}\text { Fácies } \\
\text { Amostra } \\
\text { Localizaçāo }\end{array}$} & \multicolumn{2}{|c|}{ Granito } \\
\hline & & \\
\hline & $N$ & B \\
\hline $\mathrm{SiO}_{2}$ & 66,85 & 66,86 \\
\hline $\mathrm{TiO}_{2}$ & $<$ L. D. & $<$ L. D. \\
\hline $\mathrm{All}_{2} \mathrm{O}_{3}$ & 18,26 & 18,24 \\
\hline $\mathrm{Fe}_{2} \mathrm{O}_{3}$ & 0,36 & 0,44 \\
\hline MnO & <L. D. & $<$ L. D. \\
\hline $\mathrm{MgO}$ & <L. D. & <L. D. \\
\hline $\mathrm{BaO}$ & <L. D. & $<$ L. D. \\
\hline $\mathrm{CaO}$ & $<$ L. D. & $<$ L. D. \\
\hline $\mathrm{Na}_{2} \mathrm{O}$ & 5,92 & 5,80 \\
\hline $\mathbf{K}_{2} \mathrm{O}$ & 8,25 & 8,25 \\
\hline Sro & <L. D. & < L. D. \\
\hline Total & 99,69 & 99,65 \\
\hline
\end{tabular}

Fórmula estrutural com base em 32 oxigênios.

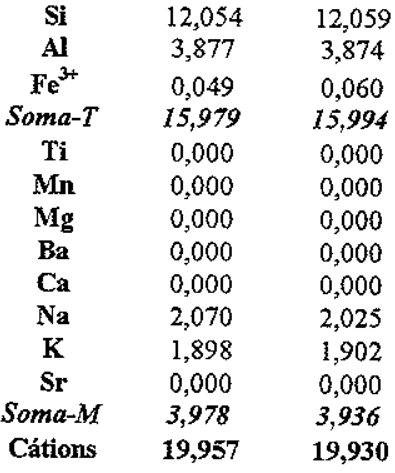

Componentes moleculares
$A b \quad 52,133$

51,650

An $\quad<0,07 \quad<0,05$

Obs: $1-\mathrm{Fe}_{\text {total }}$ calculado como $\mathrm{Fe}^{3+}$.

2- N, núcleo grão; I, região intermediária grão; B, borda grão; pt, ponto analisado. 


\section{Capítulo VI}

Geoquímica de rochas 


\section{VI.1 Geoquímica de rochas}

Neste Capítulo são apresentados e discutidos dados geoquímicos em rocha total (elementos maiores, menores e alguns traços) para um total de 13 amostras representativas das principais fácies petrográficas mapeadas no Maciço Corupá. São discutidas as tendências geoquímicas em alguns diagramas binários e ternários mais simples, dados normativos e, finalmente, alguns diagramas discriminantes de caracterização tipológica e/ou de ambientes tectônicos.

\section{VI.1.1 Apresentação dos dados}

\section{V.1.1.1 Elementos maiores e menores}

As rochas dioríticas e híbridas, sieníticas e graníticas do Maciço Corupá apresentam em conjunto uma variação química bem ampla, tal como ressaltado nos diagramas binários de tipo Harker em que utiliza-se a sílica como índice de diferenciação (Figura VI.1, ver também Tabela VI.1). Devido ao número relativamente restrito de análises obtidas, são adicionados os dados de Kaul (1997) e Kaul \& Cordani (2000) nestes diagramas. Vale a pena ressaltar que os dados destes autores foram obtidos no mesmo laboratório e com as mesmas técnicas analíticas, portanto são perfeitamente comparáveis.

Os intervalos de variação da sílica situam-se entre 49,8 e $62,3 \%$ em peso para as rochas dioríticas e híbridas. Os dioritos típicos apresentam $\mathrm{SiO}_{2}$ entre 49,8 e 52,2, enquanto que o enclave monzonítico presente nas rochas sieníticas róseas contém $57 \%$ de $\mathrm{SiO}_{2}$. As rochas sieníticas situam-se entre 61,6 e $66,3 \%$, enquanto os granitos, muito homogêneos, apresentam todos os valores de $\mathrm{SiO}_{2}$ próximos a $75 \%$.

Em geral os dados geoquímicos reafirmam a constatação efetuada por ocasião da apresentação dos dados modais (ver Capitulo IV, Item IV.3), observando-se três lacunas composicionais bem evidentes entre as composições das rochas dioríticas e sieníticas (Figura VI.1), entre o melasienito e sienitos e destes com os granitos; no primeiro caso, os dados situados 
dentro da lacuna correspondem sempre às amostras de rochas monzodioríticas e monzoníticas tipicamente híbridas.

Estes diagramas, com destaque para os envolvendo $\mathrm{MgO}$ e $\mathrm{CaO}$, mostram duas tendências evolutivas mais contrastadas que incluem os dados das rochas dioríticas e híbridas por um lado e das rochas sieníticas por outro, estas últimas com valores inferiores de ambos os óxidos. Situação similar é observada quando se plota o parâmetro mg\# (Figura VI.2, Tabela VI. I), que ressalta adicionalmente os valores bem mais elevados para este parâmetro nas rochas dioríticas, quando comparadas com o melasienito.

Tendências curvilineares homogêneas descendentes são marcadas também por $\mathrm{Fe}_{2} \mathrm{O}_{3}$, $\mathrm{TiO}_{2}$ e $\mathrm{P}_{2} \mathrm{O}_{5}$. Os valores de $\mathrm{Al}_{2} \mathrm{O}_{3}$ caracterizam uma inflexão bem marcada próximo a $\mathrm{SiO}_{2}=$ $62 \%$, separando por um lado as rochas dioríticas e híbridas das rochas sieníticas e graníticas. Os demais óxidos são dispersos de modo mais irregular nestes diagramas binários (Figura VI.1).

As tendências evolutivas contrastantes para os conjunto de rochas dioríticas e híbridas e de rochas sieníticas são bem destacas nos diagramas binários em que se plotam as quantidades de $\mathrm{CaO}, \mathrm{MgO}$ e $\mathrm{Fe}_{2} \mathrm{O}_{3}$ contra $\mathrm{Al}_{2} \mathrm{O}_{3}$ (Figura VI.3), ressaltando também trajetórias evolutivas distintas para estas rochas. Por outro lado o diagrama $\mathrm{MgO}$ vs $\mathrm{CaO}$ (Figura VI.3) mostra uma boa correlação positiva para todas as amostras analisadas do maciço.

As rochas dioríticas e híbridas são de natureza potássica (alto potássio, de acordo com Peccerillo \& Taylor, 1976), os dioritos mais típicos apresentando $\mathrm{K}_{2} \mathrm{O}$ entre 1,9 e 2,8 \% em peso. É interessante notar que estas rochas são comparativamente mais ricas em $\mathrm{Fe}_{2} \mathrm{O}_{3}$, quando são consideradas rochas dioríticas similares que afloram nos Granitos da Graciosa (Gualda, dados inéditos) ou na Província Itu (e.g., Vlach, 1993) e plotam no domínio tolético do diagrama AFM (Figura VI.4) de Irvine \& Baragar (1971).

Os teores em álcalis $\left(\mathrm{Na}_{2} \mathrm{O}+\mathrm{K}_{2} \mathrm{O}\right)$ das rochas do Maciço Corupá são em média relativamente elevados, superiores a $5 \%$ em peso nas rochas dioríticas e no melasienito, chegando a $12 \%$ nas rochas sieníticas. Considerando as relações entre álcalis e sílica (Figura VI.5), as rochas dioriticas, híbridas e sieníticas seriam alcalinas, enquanto o granito seria subalcalino na concepção de Irvine \& Baragar (1971). 
As relações entre os álcalis e a alumina (Figura V.6, ver também Tabela VI.1), expressas através do parâmetro ISA (Índice de Saturação em Alumina) ou A/CNK, A/NK ou ainda o parâmetro IA (Índice Agpaítico) revelam que as rochas dioríticas, híbridas, melasieníticas, bem como a maioria das rochas sieníticas são metaluminosas ( $\mathrm{A} / \mathrm{CNK}<1,0$ e $\mathrm{A} / \mathrm{NK}>1,0)$, apenas os sienitos mais diferenciados e as rochas graníticas são peralcalinas $(\mathrm{A} / \mathrm{CNK}<1,0$ e $\mathrm{A} / \mathrm{NK}<1,0)$, um fato já evidenciado pela análise petrográfica.

\section{V.1.1.2 Mineralogia Normativa}

Dados normativos para as amostras estudadas são apresentados na Tabela VI.2. Uma vez que não estão disponíveis valores para $\mathrm{FeO}$ nas análises químicas, as razões entre $\mathrm{FeO}$ e $\mathrm{Fe}_{2} \mathrm{O}_{3}$ foram estimadas assumindo-se $\mathrm{Fe}_{2} \mathrm{O}_{3}=\mathrm{TiO}_{2}+1,5$ (e.g., Middlemost, 1985).

As rochas dioríticas típicas e o melasienito apresentam uma mineralogia normativa típica das rochas saturadas em sílica, com olivina e hyperstênio normativos, mas sem Quartzo. As demais rochas híbridas, sieníticas e graníticas são naturalmente supersaturadas, apresentando quantidades variáveis de quartzo normativo. O granito e duas amostras mais diferenciadas de rochas sieníticas contêm acmita normativa, compatível com o seu caráter peralcalino $(\mathrm{A} / \mathrm{NK}>$ $1,0)$.

O Índice de Diferenciação (ID) (ver Tabela VI.2) de Thorton \& Tuttle (1960) é próximo a 53 para o melasienito, varia entre 47 e 77 para as rochas dioríticas e híbridas, entre 83 e 88 para as rochas sieníticas e apresenta-se igual a 92 para o granito analisado, correlacionando-se positivamente com $\mathrm{SiO}_{2}$ e negativamente com o parâmetro mg\#. Nas Figuras VI.7 e VI.8 valores normativos são plotados nos diagramas saturados em $\mathrm{H}_{2} \mathrm{O}$ residual da petrogênese Qz-Ab-Or e An-Ab-Or. É interessante observar que a amostra de granito plota próximo ao mínimo para 2 Kbar no primeiro diagrama, correspondente a aproximadamente $6,0 \mathrm{~km}$ de profundidade, um resultado de certa forma incompatível com as informações geológicas sugestivas de cristalização mais rasa. 


\section{V.1.1.3 Elementos traços}

Diagramas binários simples para os elementos traços mais relevantes (Tabela VI.1) são apresentados nas Figuras VI.9 e VI.10 e novamente ressaltam os contrastes entre as rochas dioríticas e híbridas, sieníticas e graníticas. Estes diagramas destacam principalmente as correlações moderadas a boas entre $\mathrm{SiO}_{2}$ e $\mathrm{Y}, \mathrm{Zr}$ e a razão $\mathrm{Rb} / \mathrm{Sr}$ para o conjunto das rochas sieníticas e graníticas (Figura VI.9). Os teores de $\mathrm{Sr}$ observados para as rochas dioríticas e híbridas e para o melasienito são bem superiores e contrastados dos equivalentes observados para as rochas sieníticas e graníticas, como ilustrado pelo diagrama $\mathrm{Ba}$ vs. $\mathrm{Sr}$ (Figura VI.10). É interessante observar também que $\mathrm{TiO}_{2}$ e $\mathrm{Zr}$ têm comportamento oposto no conjunto de rochas sieníticas e graníticas (Figura VI.11).

\section{VI.1.1.4 Algumas inferências extraídas da geoquimica}

Os diagramas binários simples, com destaque para os de tipo Harker, não são os mais adequados para a extração de informações genéticas, devido principalmente ao problema de fechamento, mas permitem avaliar de forma qualitativa algumas hipóteses.

Nos diagramas apresentados nas Figuras VI.9 e VI.10 são bem ressaltados os contrastes químicos entre rochas dioríticas típicas, híbridas, melasieníticas, sieníticas e graníticas e, demonstram a existência de lacunas composicionais bem marcadas entre estas rochas.

A distribuição dos dados obtidos nos diagramas para $\mathrm{CaO}$ e $\mathrm{MgO}$ vs. $\mathrm{SiO}_{2}$ mostram tendências medianamente lineares para as rochas dioríticas e híbridas, com um extremo mais félsico de composição sienítica (ver Figura VI.1), fato compatível com as informações geológicas e petrográficas indicativas de processos de mistura entre magmas básicointermediários e sieníticos e mecanismos de hibridismo (e.g., presença de enclaves híbridos monzoníticos em sienitos róseos de granulação média).

As tendências observadas nos diagramas de tipo Harker, ao lado das observadas nos diagramas $\mathrm{CaO}, \mathrm{MgO}$ e $\mathrm{Fe}_{2} \mathrm{O}_{3}$ vs. $\mathrm{Al}_{2} \mathrm{O}_{3}$ são aparentemente compatíves com a formação de rochas "cumuláticas" melasieníticas a partir da diferenciação simples de magmas sieníticos. De fato, não é difícil imaginar, pela inspeção destes diagramas, que a composição da rocha 
melasienítica pode ser visualizada por uma combinação de óxidos de $\mathrm{Fe}$ e Ti, olivina fayalítica e clinopiroxênio com liquidus sienítico (ver análises químicas de minerais nas Tabela V.I e V.2, Capitulo $V$ ). Da mesma forma as rochas graníticas devem ter se originado a partir de magmas de composições sieníticas, possivelmente por fracionamento de anfibólios cálcicos e cálcio-sódicos, uma hipótese já demonstrada na literatura por Giret et al. (1980) e também sugerida por Kaul (1997). Entretanto, os dados disponiveis sugerem que em algum momento deve ter havido a separação do liquidus granítico de um "mush" sienítico com liquidus intersticial granítico, que cristalizou como um "batch" discreto.

Por outro lado, não parece viável originar liquidus sieníticos com composições similares às das rochas sieníticas aflorantes, a partir da diferenciação direta, simples, de magmas de composições dioríticas similares às das rochas dioríticas que afloram no maciço. As fases potenciais a serem fracionadas (plagioclásio e clinopiroxênio principalmente) contêm teores de $\mathrm{SiO}_{2}$ próximos a 57-58 \% (andesina cálcica) e 50-52\% respectivamente, valores muito próximos ou superiores aos valores medidos para o diorito mais primitivo encontrado $\left(\mathrm{SiO}_{2}=49,8 \%\right)$, incompatibilizando a geração de resíduos sieníticos por extração destas fases.

Neste sentido, se os magmas que originaram as rochas sieníticas do Maciço Corupá foram originados a partir do fracionamento de magmas parentais básico-intermediários, estes não afloram ao nível atual de erosão e não correspondem às rochas dioríticas observadas ou, alternativamente, as rochas dioríticas encontradas representam uma combinação destes magmas parentais menos diferenciados com parcelas significativas de materiais crustais incorporados.

É interessante observar que, de acordo com os dados de Kaul (1997) e Kaul \& Cordani (2000) para os elementos terras raras; pelo menos uma das amostras de sienitos analisadas, correspondente à fácies sienítica verde de granulação grossa, não apresenta anomalias negativas de Eu (ver Capítulo II, Item II.2). Se a ausência desta anomalia não for devida a um mecanismo de acúmulo de feldspato alcalino e sim uma característica dos magmas originais, fica aberta a perspectiva para pensar na hipótese de magmas sieníticos parentais. Dados geoquímicos e isotópicos adicionais são necessários para discutir as possíveis hipóteses em maior detalhe e profundidade. 


\section{V.1.1.5 Dados geoquimicos e diagramas discriminantes}

Nas Figuras VI.12, VI.13 e VI.14 os dados geoquímicos obtidos para o Maciço Corupá são analisados no contexto de alguns diagramas discriminantes de Whalen $e$ t al. (1987) e Pearce et al. (1984).

No primeiro diagrama o índice agpaítico (IA) é correlacionado com a somatória de elementos traços (elementos terras raras leves, representados pelo $\mathrm{Ce}$ e elementos de alto potencial iônico-HFSE, representados por $\mathrm{Zr}, \mathrm{Nb}$ e $\mathrm{Y}$ ), nos seguintes se analisam as relações entre $\mathrm{Rb}$ e $(\mathrm{Y}+\mathrm{Nb})$ e entre $\mathrm{Nb}$ e $\mathrm{Rb}$.

O primeiro diagrama presta-se bem para a discriminação dos granitos de Tipo-A dos demais tipos I, S e M, pois os primeiros apresentam índices agpaíticos e teores de ETRL e HFSE bem superiores, uma característica bem marcada nas rochas, principalmente sieníticas e graníticas, do Maciço Corupá. De fato, apenas alguns granitos de Tipo-I muito fracionados chegam a apresentar quantidades destes elementos comparáveis às quantidades mais baixas encontradas em associações petrográficas de Tipo-A.

Nos diagramas de Pearce et al. (1984) (Figuras VI.13 e VI.14), como esperado, as amostras tanto das variedades dioríticas e híbridas, como das rochas sieníticas e graníticas do Maciço Corupá localizam-se, principalmente, no campo corespondente ao magmatismo intraplaca, uma característica já apontada por Kaul (1997) e Kaul e Cordani (1998).

No diagrama de Eby (1992), relacionando os elementos Nb, Y e Ce (Figura V.15), os dados para o maciço localizam-se na porção inferior do diagrama (campo A2). Segundo o autor, estas características são mais comuns em associações de Tipo-A derivadas da crosta continental ou fontes crustais geradas por "underplating", que passaram por um ciclo anterior de colisão continental ou de magmatismo de ambientes de arcos-de-ilha.

Estas características são compativeis com as interpretações correntes para a ambientação, não somente do magmatismo no Maciço Corupá, mas de forma geral, para os eventos magmáticos que originaram as associações petrográficas aluminosas e alcalina de Tipo-A que 
constituem a Província Serra do Mar (e.g., Siga Jr. et al, 1993; Vlach et al., 1996; Kaul, 1997 ; Kaul \& Cordani, 2000; Gualda, 2001). 
Tab.VI.1: Análises quimicas, em rocha total, dos elementos maiores, menores (em \% de óxido) e traços (em ppm) das principais fácies petrográficas do Maciço Corupá.

\begin{tabular}{|c|c|c|c|c|c|c|c|c|c|c|c|c|c|}
\hline Amostra & CO-2A & $\mathrm{CO}-3 \mathrm{~B}$ & $\mathrm{CO}-32 \mathrm{~A}$ & CO-51 & CO-38 & $\mathrm{CO}-32 \mathrm{C}$ & $\mathrm{C} 0-50 \mathrm{~A}$ & $\mathrm{CO}-5$ & CO-32D & $\mathrm{CO}-22$ & CO-34B & CO-45D & $\mathrm{CO}-6 \mathrm{C}$ \\
\hline Fácies & Gran. & SRG & SRG & $\mathrm{SRG}$ & SRM & SVG & SVG & SVM & Melas. & Dior. & R. Híb. & R. Hb. & Enc. Monz. \\
\hline $\mathrm{SiO}_{2}$ & 74,63 & 65,70 & 61,62 & 61,86 & 66,30 & 61,88 & 61,88 & 63,31 & 49,98 & 49,81 & 52,24 & 63,72 & 56,96 \\
\hline $\mathrm{TiO}_{2}$ & 0,17 & 0,56 & 0,89 & 0,87 & 0,48 & 0,89 & 0,84 & 0,56 & 3,39 & 2,63 & 2,69 & 0,81 & 1,32 \\
\hline $\mathrm{Al}_{2} \mathrm{O}_{3}$ & 11,58 & 14,76 & 16,17 & 16,55 & 14,25 & 16,11 & 16,58 & 16,26 & 11,29 & 14,20 & 14,49 & 15,10 & 15,26 \\
\hline $\mathrm{Fe}_{2} \mathrm{O}_{3}$ & 2,87 & 5,51 & 5,95 & 5,87 & 5,54 & 6,14 & 5,95 & 5,23 & 19,40 & 13,59 & 11,79 & 5,35 & 8,77 \\
\hline Mno & 0,06 & 0,19 & 0,20 & 0,20 & 0,17 & 0,19 & 0,20 & 0,19 & 0,06 & 0,24 & 0,23 & 0,12 & 0,20 \\
\hline MgO & 0,06 & 0,20 & 0,60 & 0,63 & 0,16 & 0,64 & 0,53 & 0,24 & 2,85 & 3,99 & 3,10 & 1,07 & 2,50 \\
\hline $\mathrm{CaO}$ & 0,64 & 1,40 & 1,93 & 1,93 & 1,19 & 2,11 & 2,13 & 1,47 & 4,75 & 7,51 & 5,92 & 2,72 & 4,58 \\
\hline $\mathrm{Na}_{2} \mathrm{O}$ & 4,45 & 5,70 & 5,20 & 5,29 & 5,52 & 5,23 & 5,48 & 5,86 & 3,51 & 4,23 & 4,90 & 4,50 & 5,09 \\
\hline $\mathbf{K}_{2} \mathbf{O}$ & 4,63 & 5,46 & 5,75 & 5,97 & 5,25 & 5,71 & 5,88 & 5,82 & 3,87 & 1,88 & 2,79 & 3,95 & 3,77 \\
\hline $\mathrm{P}_{2} \mathrm{O}_{5}$ & 0,01 & 0,04 & 0,17 & 0,20 & 0,03 & 0,20 & 0.17 & 0,06 & 0,94 & 0,38 & 0,98 & 0,17 & 0,33 \\
\hline LOI & 0,48 & 0,17 & 0,51 & 0,66 & 0,25 & 0,54 & 0,38 & 0,50 & $<0,01 *$ & 1,41 & 0,77 & 2,29 & 0,79 \\
\hline Total & 99,58 & 99,68 & 98,99 & 100,03 & 99,14 & 99,64 & 100,01 & 99,51 & 100,04 & 99,88 & 99,89 & 99,81 & 99,57 \\
\hline $\mathrm{H}_{2} \mathrm{O}$ & 0,25 & 0,22 & 0,56 & 0,52 & 0,55 & 0,51 & 0,41 & 0,55 & 0,26 & 0,39 & 0,33 & 0,30 & 0,49 \\
\hline $\mathbf{B a}$ & 17 & 52 & 615 & 661 & 124 & 1171 & 710 & 127 & 1574 & 1168 & 1649 & 2431 & 1170 \\
\hline Be & 9 & 4 & s/a & 3 & $\mathrm{~s} / \mathrm{a}$ & $\mathrm{s} / \mathrm{a}$ & 3 & 3 & $\mathrm{~s} / \mathrm{a}$ & $\mathrm{s} / \mathrm{a}$ & 3 & 4 & 3 \\
\hline $\mathrm{Ce}$ & 255 & 263 & 60 & 86 & 412 & 85 & 102 & 144 & 212 & 97 & 123 & 131 & 212 \\
\hline CI & 138 & 80 & 193 & 75 & 87 & 137 & 36 & 130 & $<237$ & 310 & 189 & 73 & 85 \\
\hline Co & $<3$ & $<3$ & $<1$ & $<3$ & $<1$ & 2 & $<3$ & $<3$ & 14 & 29 & 20 & $<3$ & 14 \\
\hline $\mathrm{Cr}$ & 11 & 5 & 5 & 2 & 7 & $<2$ & 5 & 5 & 43 & 26 & 10 & 12 & 44 \\
\hline $\mathrm{Cu}$ & 2 & 4 & 6 & 6 & $<1$ & 6 & 4 & 4 & 13 & 21 & 12 & 0 & 13 \\
\hline $\mathbf{F}$ & 2572 & 1161 & 609 & 457 & 158 & 544 & 332 & 354 & 908 & 704 & 1383 & 749 & 643 \\
\hline Ga & 29 & 27 & 19 & 22 & 27 & 23 & 23 & 26 & 22 & 23 & 21 & 23 & 22 \\
\hline La & 102 & 95 & 46 & 59 & 237 & 65 & 62 & 47 & 111 & 59 & 69 & 70 & 107 \\
\hline $\mathrm{Nb}$ & 44 & 31 & 20 & 14 & 30 & 16 & 14 & 17 & 19 & 10 & 15 & 20 & 19 \\
\hline Nd & 88 & 84 & 40 & 30 & 155 & 39 & 62 & 51 & 82 & 44 & 71 & 53 & 73 \\
\hline $\mathrm{Ni}$ & 1 & 2 & 2 & 3 & 1 & 1 & 2 & 3 & 14 & 7 & 3 & 6 & 14 \\
\hline $\mathbf{P b}$ & 61 & 33 & 8 & 22 & 16 & 8 & 15 & 26 & 14 & 8 & 17 & 21 & 14 \\
\hline $\mathbf{R b}$ & 180 & 99 & 46 & 45 & 89 & 35 & 43 & 55 & 38 & 21 & 44 & 59 & 40 \\
\hline $\mathrm{s}$ & $<20$ & $<20$ & $<20$ & 77 & $<20$ & 71 & $<20$ & $<20$ & 104 & 484 & 636 & $<20$ & 152 \\
\hline Sc & $<10$ & 11 & 10 & 15 & $<10$ & 13 & 17 & 10 & 76 & 33 & 28 & $<10$ & 18 \\
\hline $\mathrm{Sr}$ & 19 & 15 & 48 & 54 & $<15$ & 55 & 46 & 17 & 305 & 317 & 368 & 245 & 313 \\
\hline Th & 58 & 7 & 6 & 4 & 14 & 4 & 6 & 1 & 2 & 5 & 4 & 17 & 8 \\
\hline $\mathrm{U}$ & 5 & 4 & 3 & 3 & $<3$ & $<3$ & 3 & 4 & $<3$ & $<3$ & $<3$ & 4 & 3 \\
\hline $\mathrm{v}$ & $<6$ & $<6$ & $<6$ & $<6$ & 8 & 11 & $<6$ & $<6$ & 91 & 37 & 182 & 43 & 87 \\
\hline $\mathbf{Y}$ & 121 & 66 & 26 & 34 & 77 & 32 & 34 & 36 & 51 & 41 & 58 & 53 & 50 \\
\hline $\mathrm{Zn}$ & 138 & 98 & 63 & 72 & 99 & 78 & 75 & 66 & 89 & 108 & 108 & 54 & 90 \\
\hline $\mathrm{Zr}$ & 992 & 2289 & 178 & 328 & 1445 & 286 & 350 & 1309 & 623 & 354 & 363 & 797 & 643 \\
\hline mg\# & 0,077 & 0,126 & 0,287 & 0,302 & 0,104 & 0,293 & 0,261 & 0,155 & 0,370 & 0,540 & 0,512 & 0,445 & 0,533 \\
\hline A/CNK & 0,858 & 0,826 & 0,883 & 0,885 & $\begin{array}{l}0,104 \\
0,841\end{array}$ & 0,864 & 0,860 & 0,873 & 0,606 & 0,626 & 0,662 & 0,907 & 0,734 \\
\hline ANK & 0,939 & 0,964 & 1,093 & 1,090 & 0,965 & 1,089 & 1,077 & 1,019 & 1,131 & 1,577 & 1,306 & 1,292 & 1,225 \\
\hline IA & 1,065 & 1,037 & 0,915 & 0,917 & 1,036 & 0,918 & 0,928 & 0,981 & 0,884 & 0,634 & 0,766 & 0,774 & 0,816 \\
\hline
\end{tabular}

Obs: 1- Lol: perda ao fogo; 2-(*): valor negativo, não indicado; 3- Abreviaçôes das fấcies: Gran.: granito, SRG: sienito róseo grosso, SRM: sienito róseo médio, SVG: sienito verde grosso, SVM: sienito verde médio, Melas.: melasienito,

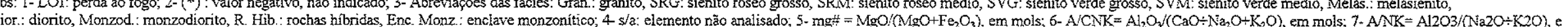
8- IA $=1 /(\mathrm{ANK})$. 
Tab.VI.2: Análises normativas (CIPW) das principais fácies petrográficas do Maciço Corupá.

\begin{tabular}{|c|c|c|c|c|c|c|c|c|c|c|c|c|c|}
\hline Amostra & $\mathrm{CO}-2 \mathrm{~A}$ & $\mathrm{CO}-3 \mathrm{~B}$ & $\mathrm{CO}-32 \mathrm{~A}$ & CO-51 & CO-38 & $\mathrm{CO}-32 \mathrm{C}$ & C0-50A & $\mathrm{CO}-5$ & $\mathrm{CO}-32 \mathrm{D}$ & $\mathrm{CO}-22$ & CO-34B & CO-45D & $\mathrm{CO}-6 \mathrm{C}$ \\
\hline Fácies & Gran. & SRG & SRG & SRG & SRM & SVG & SVG & SVM & Melas. & Dior. & R. Hîb. & R. Híb. & nc. Monz \\
\hline $\mathbf{Q}$ & 30,86 & 8,69 & 4,60 & 3,39 & 11,10 & 4,47 & 2,56 & 3,53 & * & $*$ & $*$ & 15,15 & 0,47 \\
\hline Or & 27,36 & 32,27 & 34,15 & 35,45 & 31,06 & 34,06 & 34,94 & 34,43 & 23,31 & 11,43 & 16,93 & 24,00 & 22,60 \\
\hline $\mathbf{A b}$ & 33,79 & 45,52 & 44,00 & 44,85 & 44,02 & 44,25 & 46,37 & 49,59 & 29,79 & 35,88 & 41,46 & 38,08 & 43,07 \\
\hline An & 0,00 & 0,00 & 3,67 & 3,61 & $*$ & 3,35 & 3,13 & 0,85 & 3,27 & 13,97 & 8,99 & 8,86 & 7,44 \\
\hline Di & 1,06 & 5,11 & 3,77 & 3,76 & 5,07 & 4,69 & 5,27 & 5,06 & 12,06 & 17,00 & 11,19 & 2,61 & 10,72 \\
\hline Hy & 1,00 & 1,92 & 2,35 & 2,43 & 2,18 & 2,33 & 1,66 & 0,93 & 12,28 & 0,89 & 4,09 & 3,39 & 6,58 \\
\hline OI & $*$ & $*$ & $*$ & $*$ & $*$ & $*$ & $*$ & $*$ & 2,36 & 6,60 & 2,37 & $*$ & $*$ \\
\hline Ac & 3,41 & 2,39 & $*$ & * & 2,37 & $*$ & $*$ & $*$ & $*$ & $*$ & $*$ & $*$ & $*$ \\
\hline Mt & 0,71 & 1,79 & 3,48 & 3,44 & 1,68 & 3,47 & 3,39 & 2,99 & 7,09 & 5,99 & 6,08 & 3,35 & 4,10 \\
\hline $\mathbf{n}$ & 0,32 & 1,06 & 1,71 & 1,65 & 0,91 & 1,69 & 1,60 & 1,06 & 6,44 & 4,99 & 5,11 & 1,54 & 2,53 \\
\hline $\mathbf{A p}$ & 0,02 & 0,09 & 0,04 & 0,47 & 0,07 & 0,47 & 0,40 & 0,14 & 2,23 & 0,90 & 2,32 & 0,40 & 0,78 \\
\hline $\mathbf{Z r}$ & 0,19 & 0,46 & 0,03 & 0,06 & 0,30 & 0,06 & 0,07 & 0,27 & 0,12 & 0,07 & 0,07 & 0,16 & 0,13 \\
\hline FI & 0,53 & 0,24 & 0,09 & 0,06 & $*$ & 0,07 & 0,04 & 0,06 & 0,01 & 0,07 & 0,11 & 0,12 & 0,07 \\
\hline Total & 99,30 & 99,60 & 98,30 & 99,20 & 98,80 & 98,90 & 99,40 & 98,90 & 99,00 & 97,80 & 98,70 & 97,70 & 98,50 \\
\hline Id & 92,01 & 86,48 & 82,75 & 83,69 & 86,18 & 82,78 & 83,87 & 87,55 & 53,10 & 47,31 & 58,39 & 77,23 & 66,14 \\
\hline
\end{tabular}

Obs: 1- $\mathrm{Fe}^{2+}$ e $\mathrm{Fe}^{3+}$ calculados com base em $\mathrm{Fe}_{2} \mathrm{O}_{3}=\mathrm{TiO}_{2}+1,5$ (Middlemost, 1985); 2- Id = úndice de diferenciação (Q+Ab+Or); 3- Abreviações das fácies: Gran.: granito, SRG: sienito róseo grosso, SRM: sienito róseo médio, SVG: sienito verde grosso, SVM: sienito verde médio, Melas.: melasienito,

Dior: diorito, Monzod.: monzodiorito, R. Híb.: Rochas Híbridas, Enc. Monz.: enclave monzonítico; 4-(*) Mineral normativo ausente. 

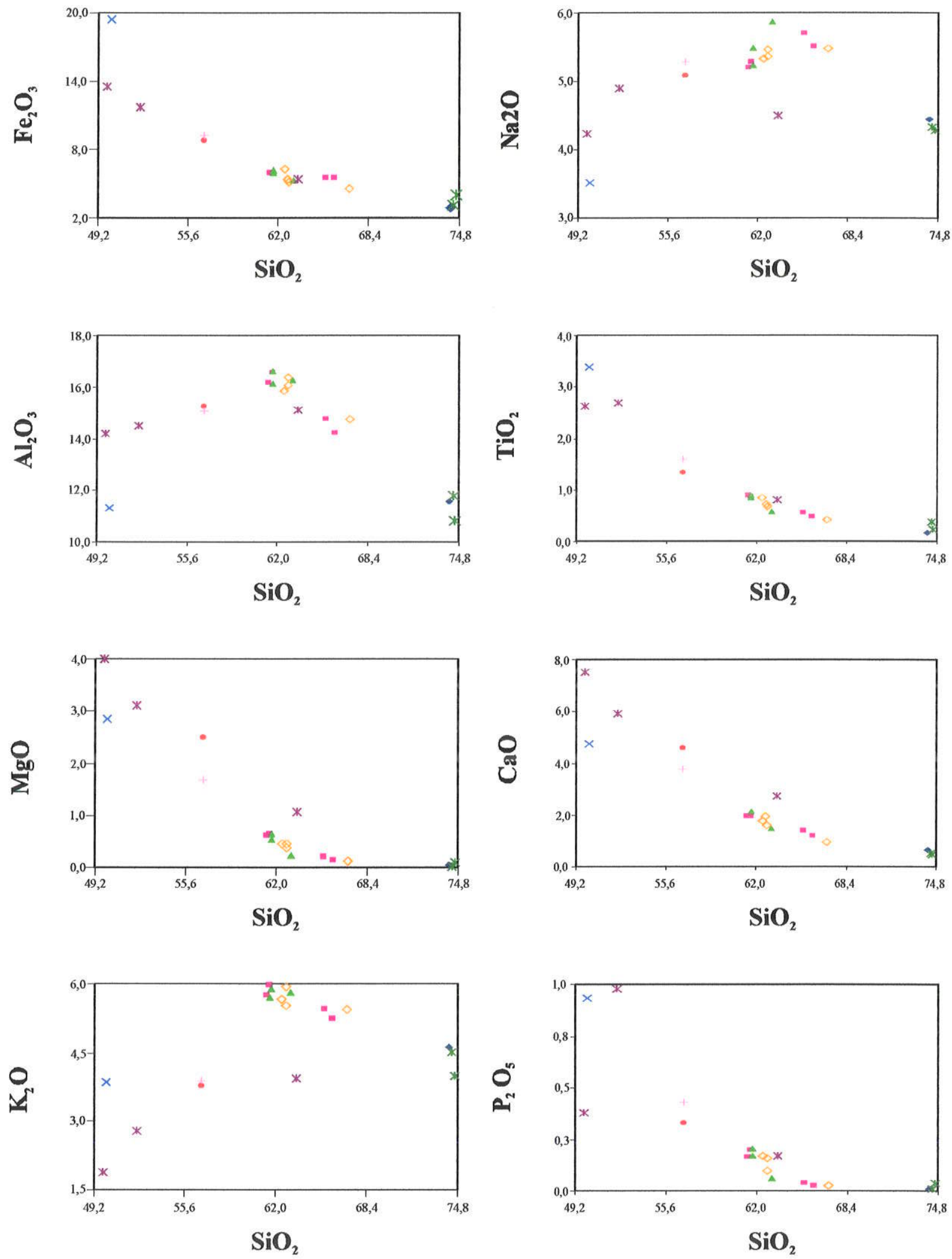

Figura VI.1. Diagramas binários de variação de tipo Harker para as fácies granítica, sieníticas, melasienítica, dioritica/rochas híbridas e enclave monzonítico. Os dados obtidos por Kaul (1997) $e$

Kaul \& Cordani (2000) para os elementos maiores e menores estão plotados nos diagramas juntamente com os dados obtidos para o presente trabalho.

- Granito $=$ Sienito Róseo $\triangle$ Sienito Verde * Melasienito * Diorito/Rochas Híbridas • Enclave Monzonítico * Granito (Kaul,1997; Kaul \& Cordani,2000) Sienito grosso (Kaul, 1997; Kaul \& Cordani, 2000) Sienito fino (Kaul, 1997; Kaul \& Cordani, 2000 


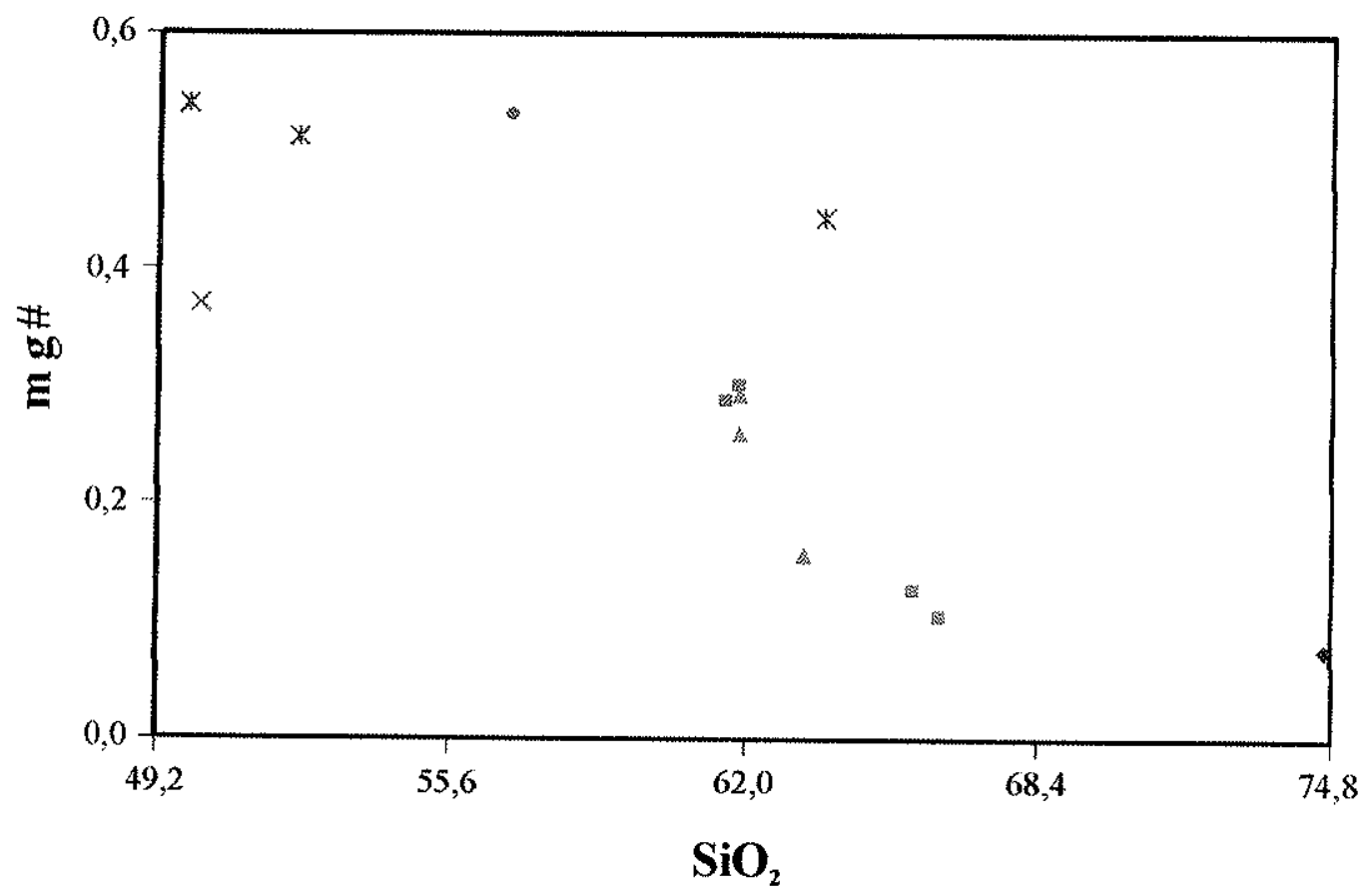

Figura VI.2. Diagrama binário de variação $\mathrm{SiO}_{2}$ vs parâmetro mgł.

- Granito * Sienito Róseo * Sienito Verde $\times$ Melasienito

* Diorito/Rochas Hibridas • Enclave Monzonítico 


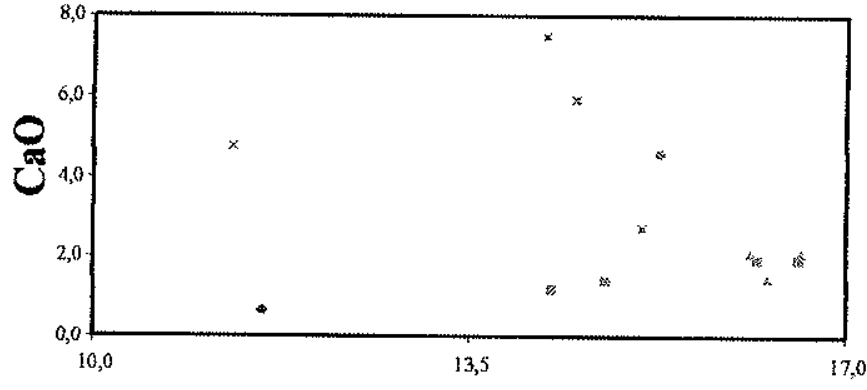

$\mathrm{Al}_{2} \mathrm{O}_{3}$

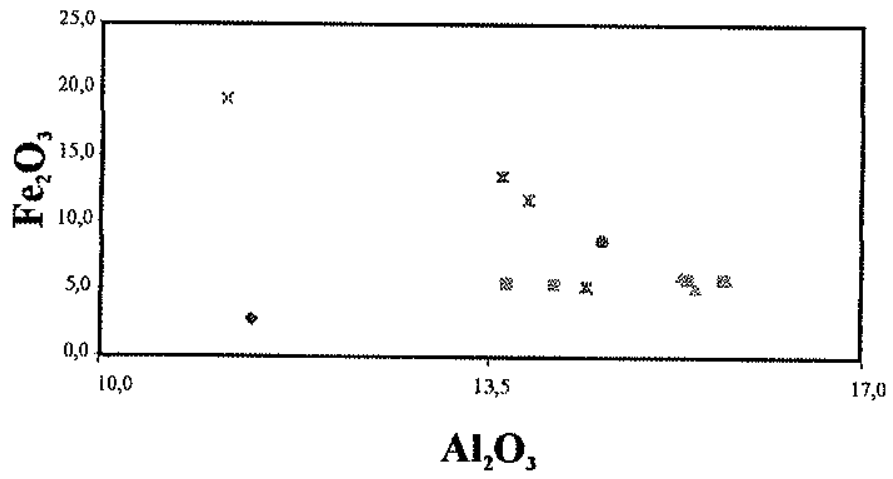

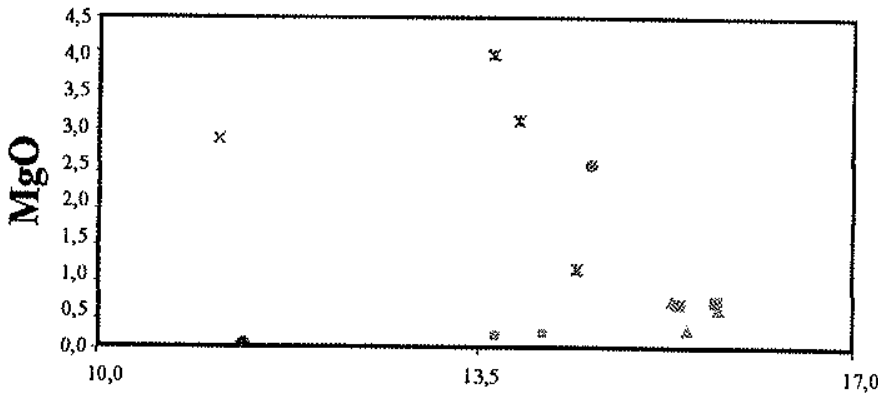

$\mathrm{Al}_{2} \mathbf{O}_{3}$

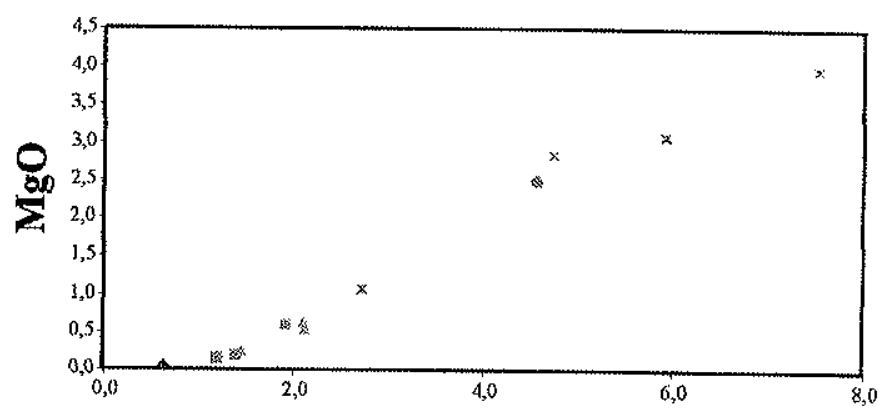

$\mathrm{CaO}$

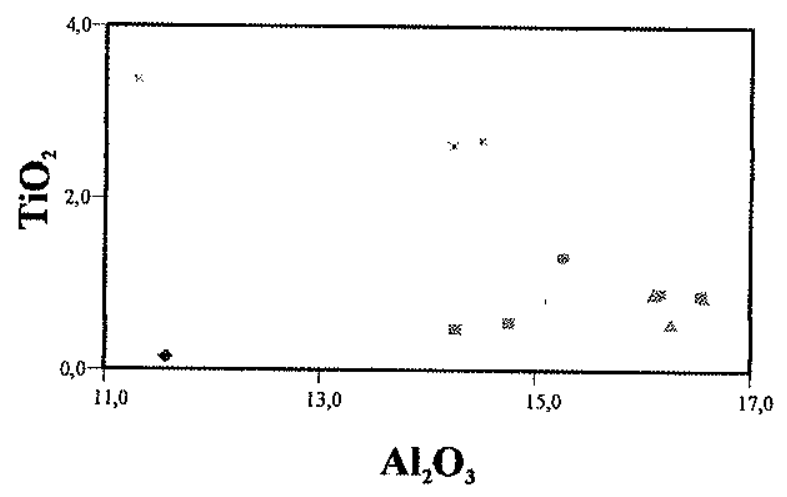

Figura VI.3. Diagramas binários de variação entre $\mathrm{CaO}, \mathrm{Fe}_{2} \mathrm{O}_{3}, 7 i \mathrm{O}_{2}, \mathrm{MgO}_{\text {v }} \mathrm{Al}_{2} \mathrm{O}_{3}$ e $\mathrm{MgO}$ us $\mathrm{CaO}$.

- Granito "Sienito Róseo "Sienito Verde $\times$ Melasienito

* Diorito/Rochas Hibridas a Enclave Monzonítico 


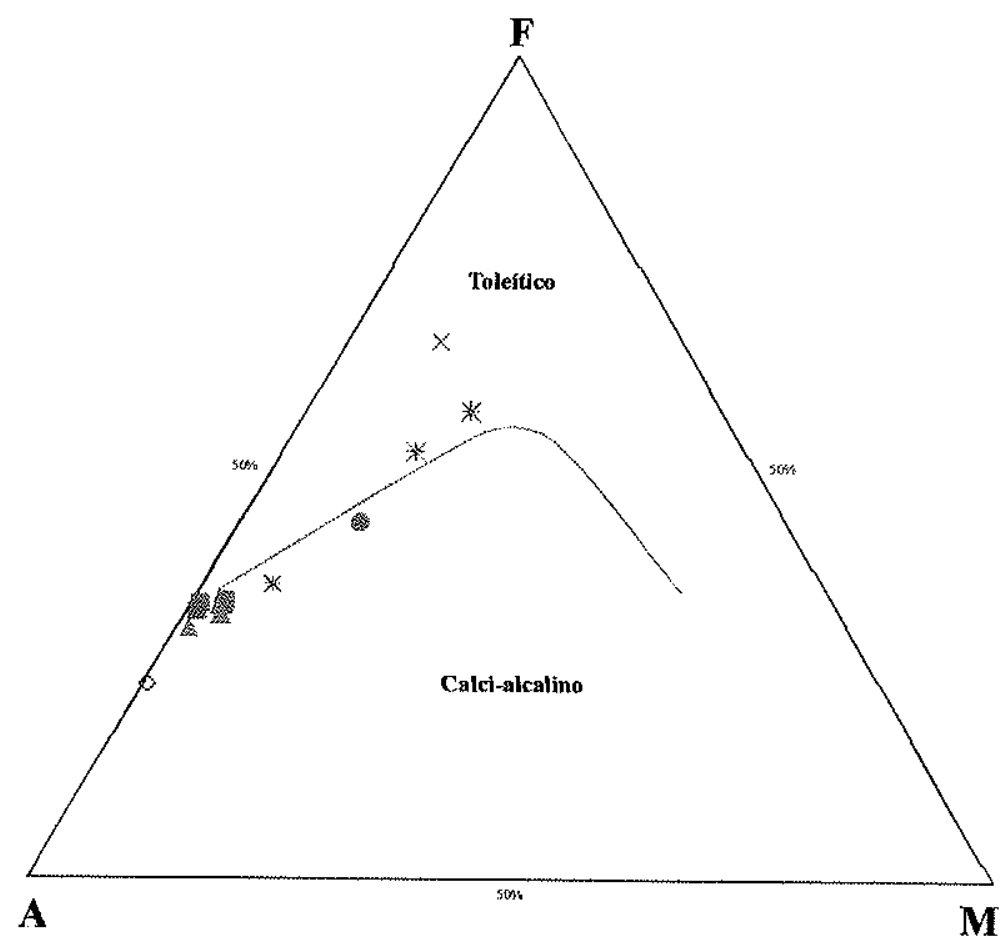

Figura VI.4. Diagrama ternário, A-F-M (Irvine \& Baragar, 1971), para as fácies granítica, sieniticas, melasienitica, dioritica/rochas hibridas e enclave monzonitico.

$\Delta$ Granito Sienito Róseo Sienito Verde Melasienito

* Dionito/Rochas Hibridas Enclave Monzonítico

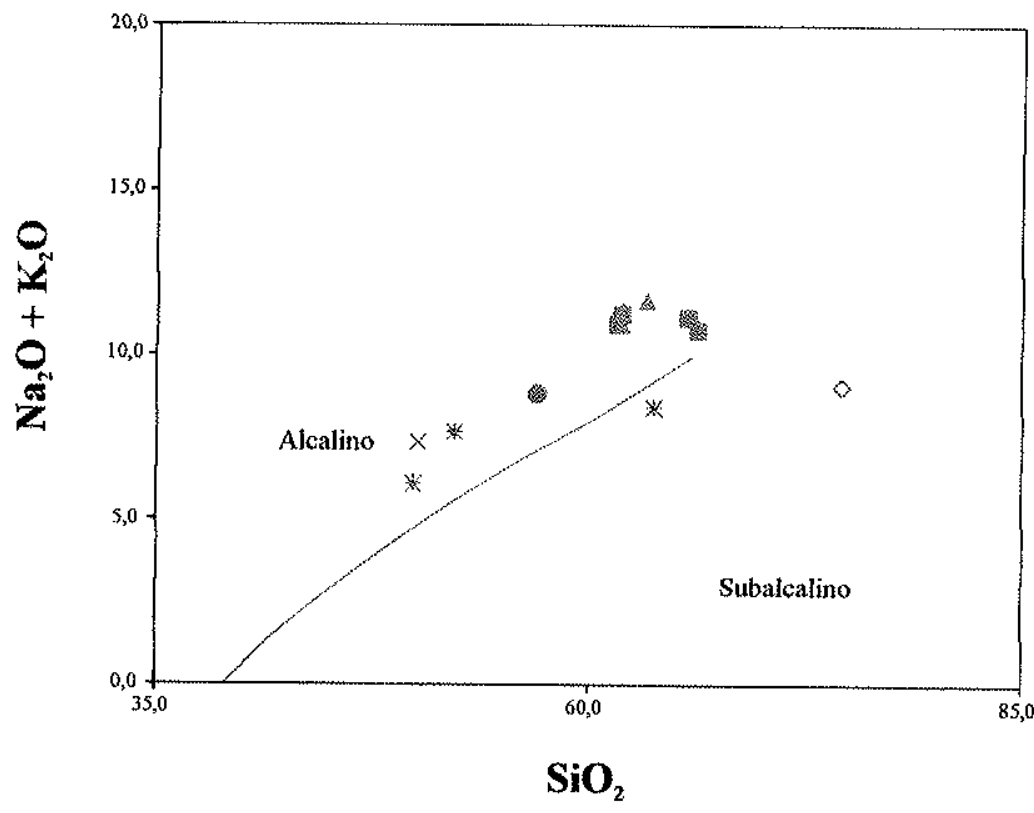

Figura VI.5. Diagrama binário de variação ( $\mathrm{SiO} \mathrm{O}_{2}$ vs . Na $\mathrm{Na}_{2} \mathrm{O}+\mathrm{K}_{2} \mathrm{O}$ ) discriminante de rochas alcalinas e subalcalinas (Irvine \& Baragar, 1971) para as fácies granitica, sieniticas, melasientica, dioritica/rochas hibridas e enclave monzonitico.

- Granito Sienito Róseo \& Sienito Verde * Melasienito

* Diorito/Rochas Híbridas Enclave Monzonítico 


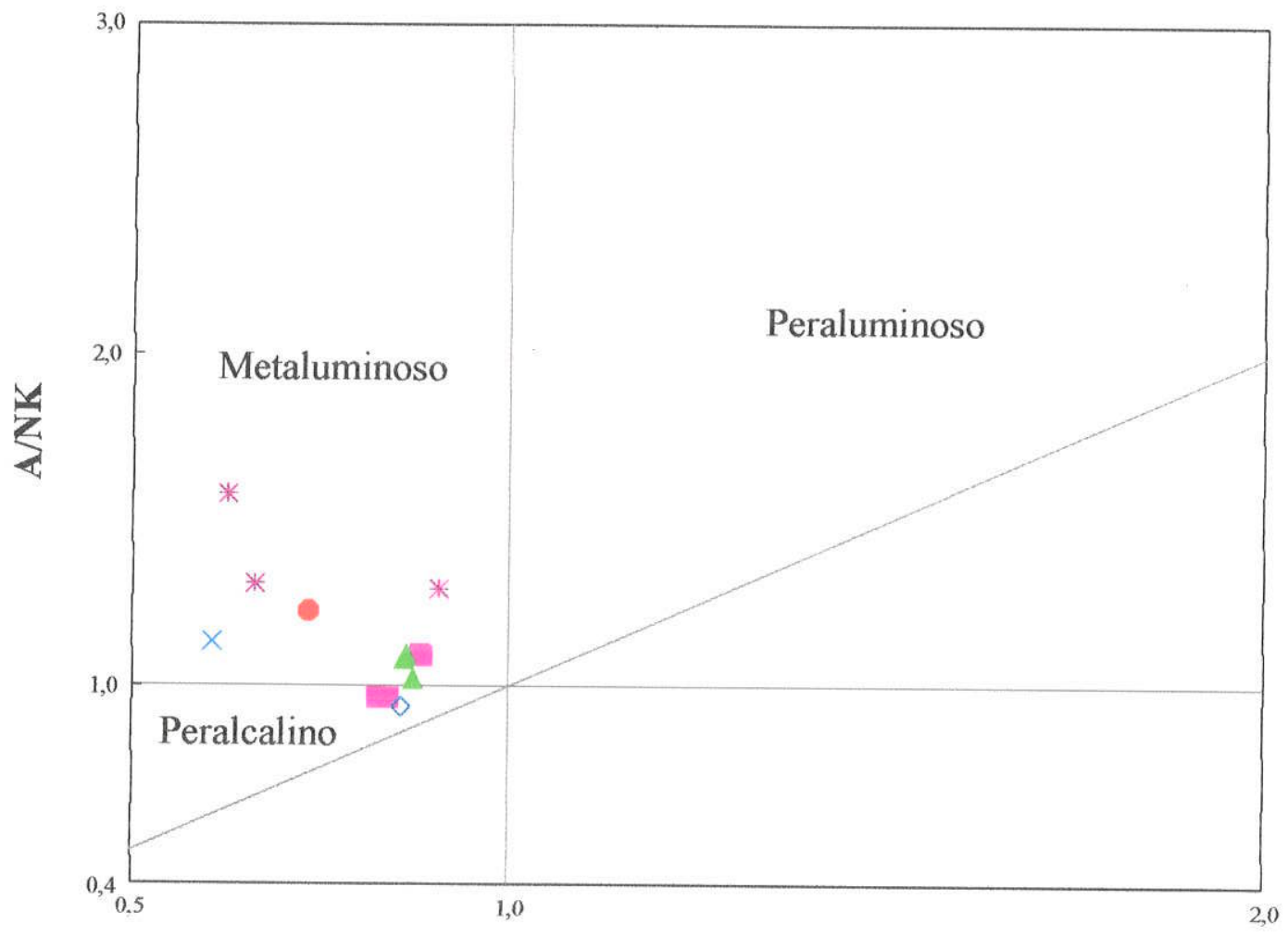

\section{$\mathrm{A} / \mathrm{CNK}$}

Figura VI.6. Diagrama binário de variação (parämetros $A / C N K$ vs $A / N K$ ) discriminante de rochas peralcalinas, metaluminas e peraluminosas (Maniar \& Piccoli, 1989) para as fácies granitica, sieniticas, melasienitica, dioritica/rochas híbridas e enclave monzonítico.

$\diamond$ Granito $=$ Sienito Róseo $\Delta$ Sienito Verde $\times$ Melasienito

* Diorito/Rochas Híbridas Enclave Monzonítico 


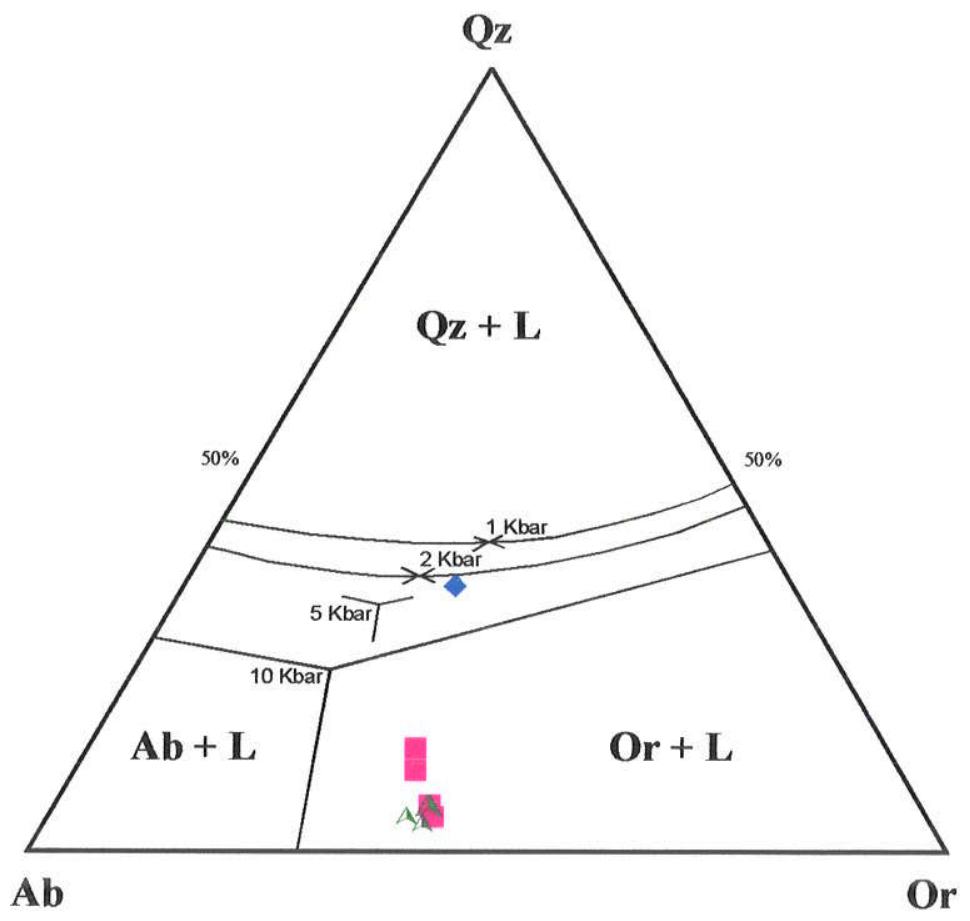

Figura VI.7. Diagrama ternário, Qz-Ab-Or (normativos), para as fácies granitica e sieníticas. As curvas de pressão para 1, 2, 5 e 10 Kbar encontram-se inseridas no diagrama (ver Tuttle \& Bowen, 1958; Johannes \& Holtz, 1996)

- Granito $=$ Sienito Róseo A Sienito Verde

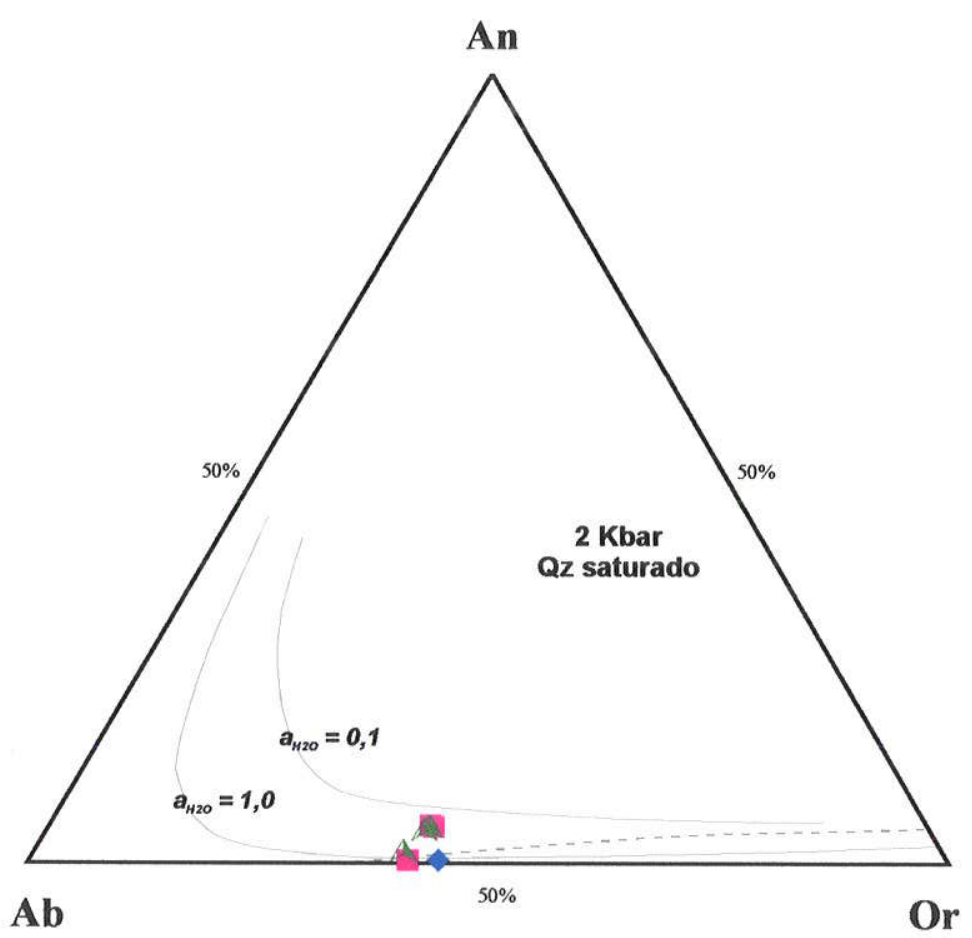

Figura VI.8. Diagrama ternário, An-Ab-Or (normativos), para as fácies granítica e sieníticas. As curvas de pressão para 2 Kbar e atividade de água $\left(a_{H 2}\right)$ a 0,1 e 1,0 encontram-se inseridas no diagrama (ver Nekvasil, 1990).

$\bullet$ Granito $=$ Sienito Róseo A Sienito Verde 

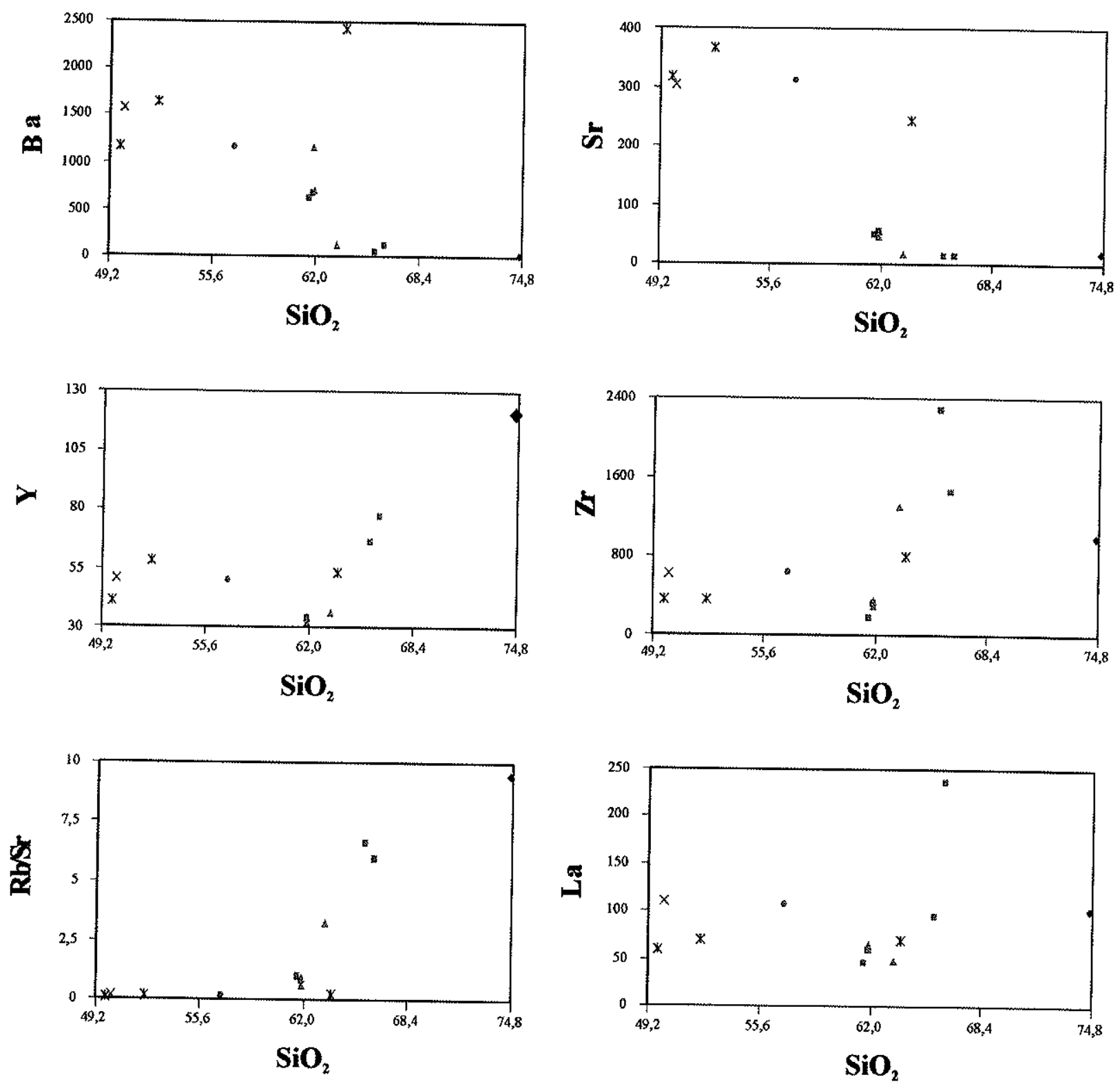

Figura VI.9. Diagramas binários de variação ( $\mathrm{SiO}_{2}$ vs.elementos traços) para as fácies granitica, sieniticas, melasienítica, dioritica/rochas hibridas e enclave monzonitico.

- Granito " Sienito Róseo " Sienito Verde × Melasienito

* Diorito/Rochas Híbridas • Enclave Monzonítico 


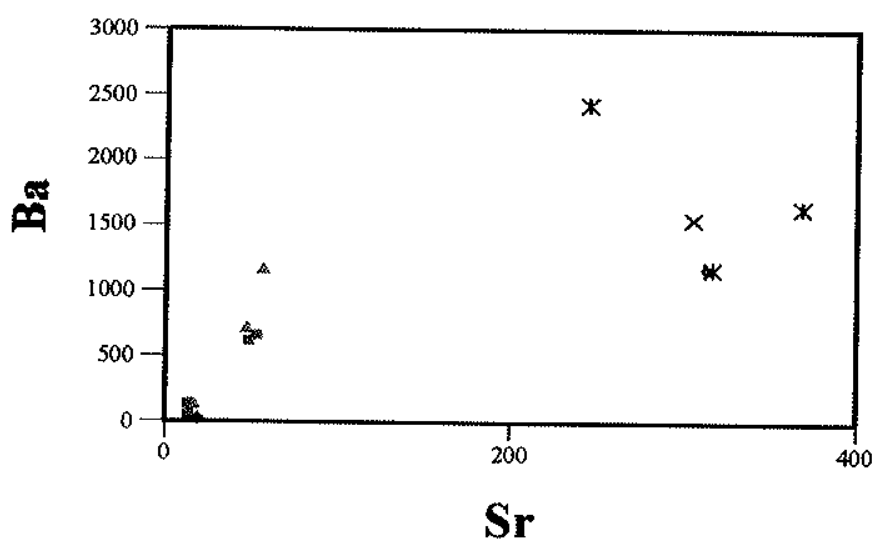

Sr

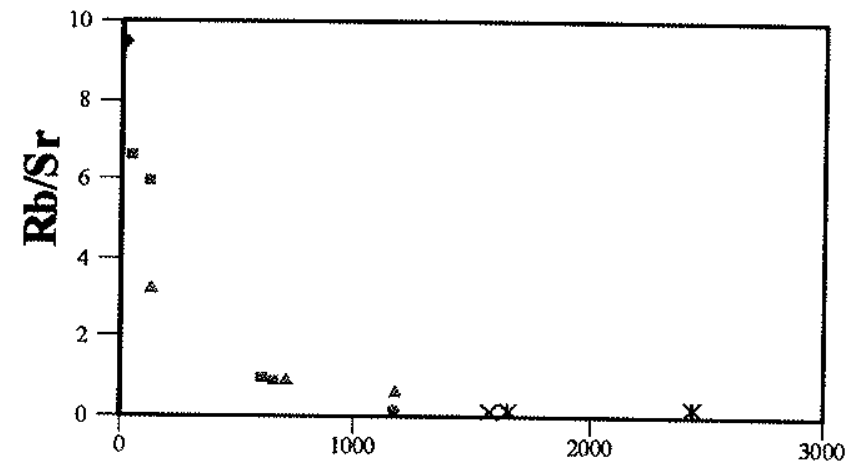

Ba

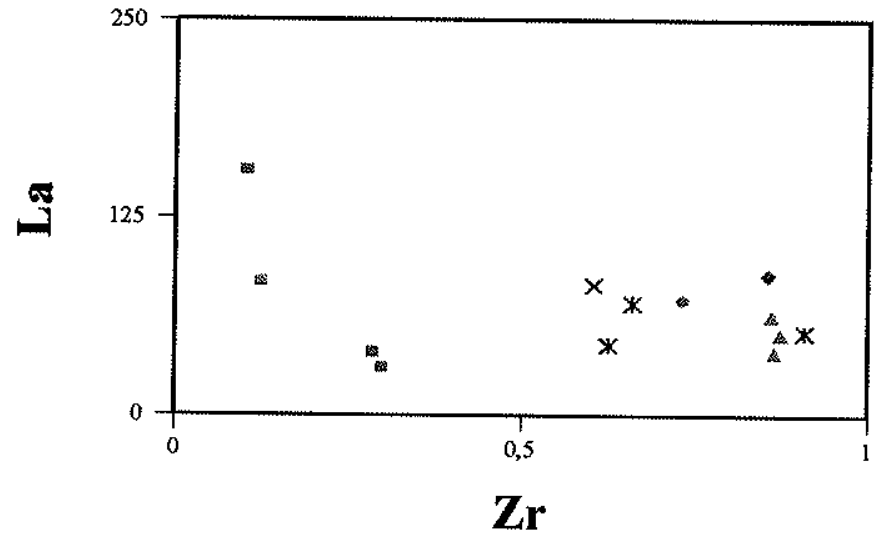

Fïura VI.10. Diagramas binários de variação entre elementos traços para as fácies granítica, sieniticas, melasienitica, dioritica/rochas hibridas e enclove monzonitico.

- Granito * Sienito Róseo * Sienito Verde $\times$ Melasienito

* Diorito/Rochas Híbridas * Enclave Monzonítico 


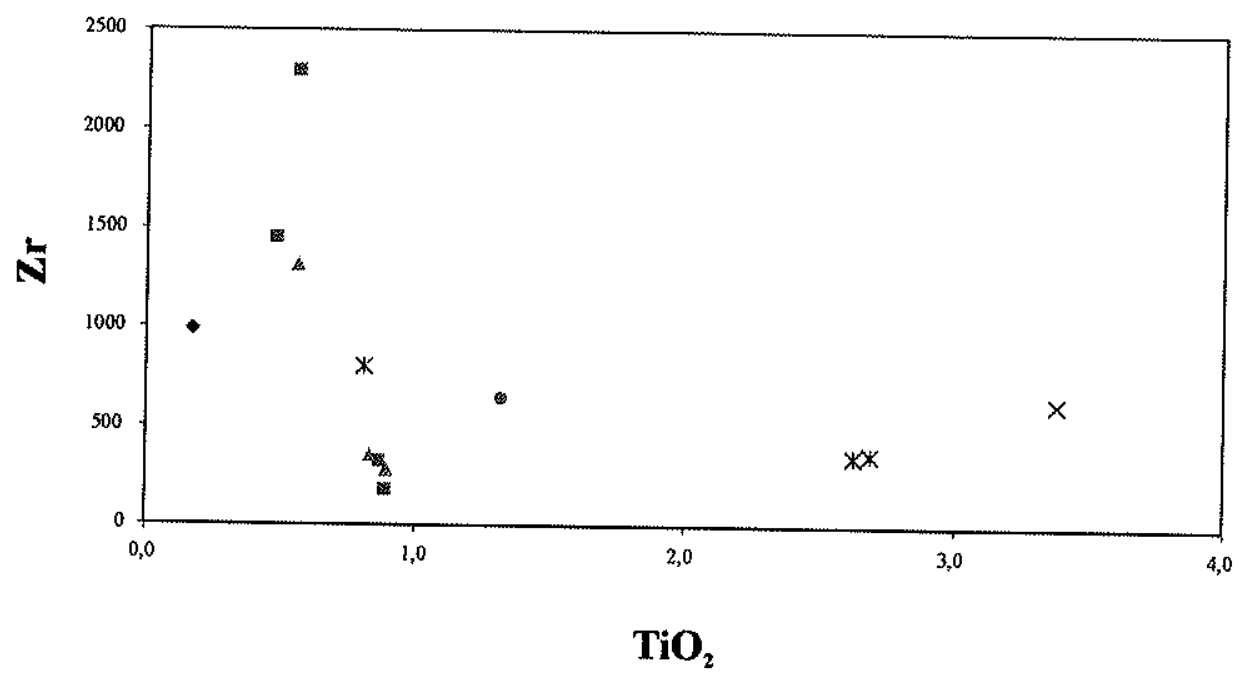

Figura VI.11. Diagrama binário de variação (TiO $\mathrm{O}_{2}$ vs $\mathrm{Zr}$ ) para as facies granitica, sieniticas, melasienitica, dioriticalrochas hibridas e enclave monzontico.

- Granito "Sienito Róseo ^ Sienito Verde × Melasienito

* Diorito/Rochas Híbridas • Enclave Monzonítico

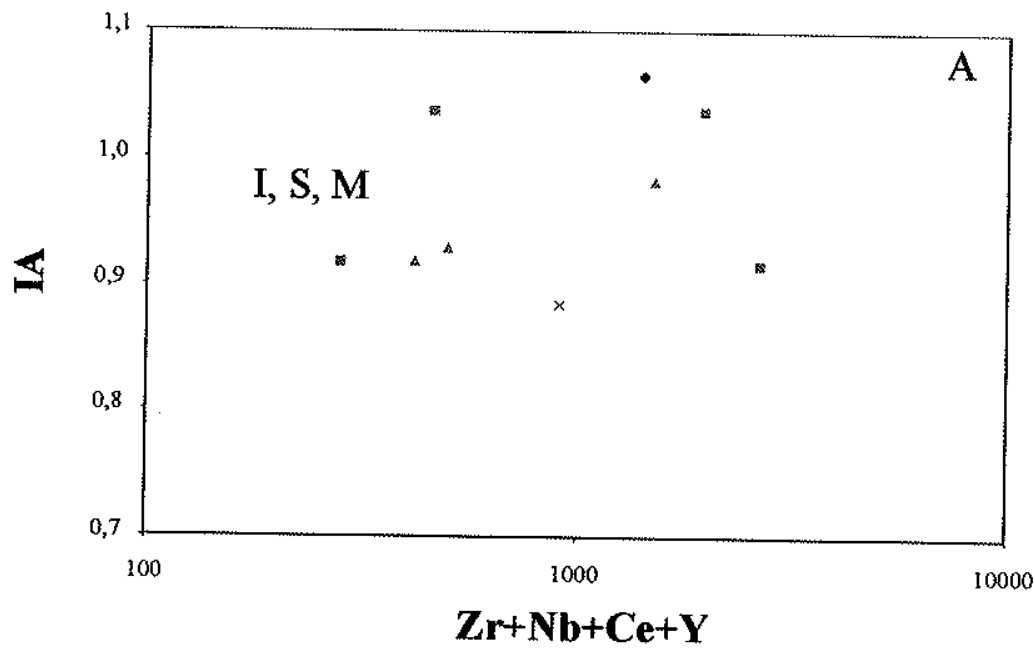

Figura VI.12. Diagrama binário de variação $(\mathrm{Zr}+\mathrm{Nb}+\mathrm{Ce}+\mathrm{Y}$ vs $\mathrm{LA})$ para as fácies granitica, sieniticas e melasienitica. Os campos discriminantes entre granitos de Tipo I, Se $M$ e de Tipo-A encontram-se indicados no diagrama (Whalen et al., 1987).

- Granito * Sienito Róseo ^ Sienito Verde × Melasienito 


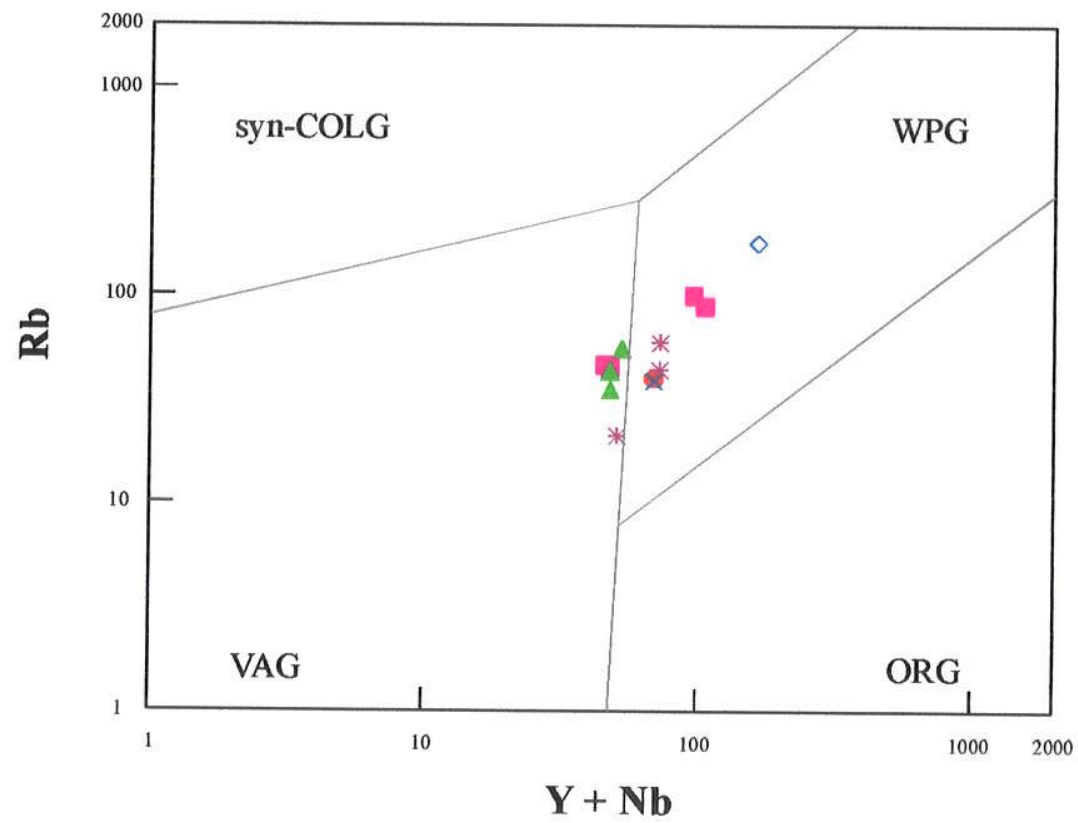

Figura VI.13. Diagrama binário de variação $(Y+N b$ vs $R b)$ para as fácies granítica, sieníticas, melasienitica, diorítica/rochas hibridas e enclave monzonitico. Os campos discriminantes entre granitos de ambientes Sin-colisionais, Intraplaca, de Arcos Vulcânicos e Orogênicos encontram-se indicados no diagrama (Pearce et al., 1984).

$\diamond$ Granito $=$ Sienito Róseo $\star$ Sienito Verde $\times$ Melasienito

* Diorito/Rochas Híbridas • Enclave Monzonítico

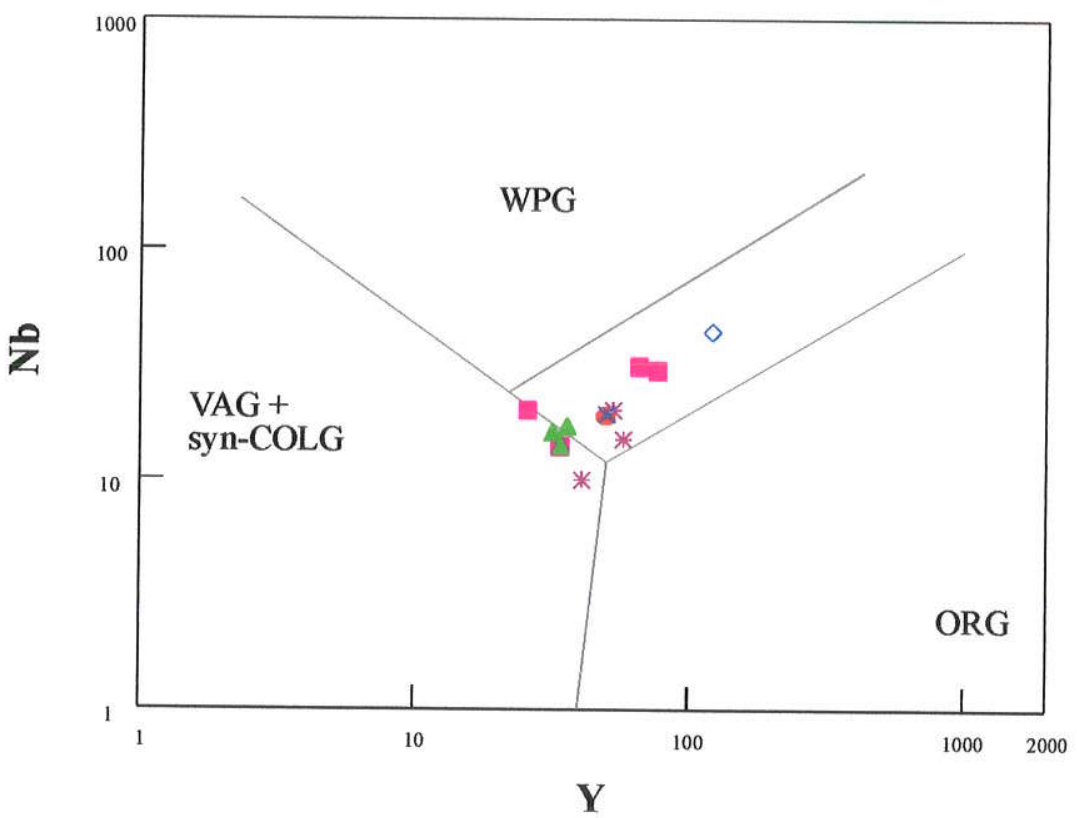

Figura VI.14. Diagrama binário de variação $(Y$ vs Nb) para as fácies granítica, sieníticas, melasienítica, dioríticalrochas hibridas e enclave monzonítico. Os campos discriminantes entre granitos de ambientes Sin-colisionais, Intraplaca, de Arcos Vulcânicos e Orogênicos encontram-se indicados no diagrama (Pearce et al., 1984).

$\diamond$ Granito $=$ Sienito Róseo $\triangle$ Sienito Verde $\times$ Melasienito

* Diorito/Rochas Híbridas • Enclave Monzonítico 


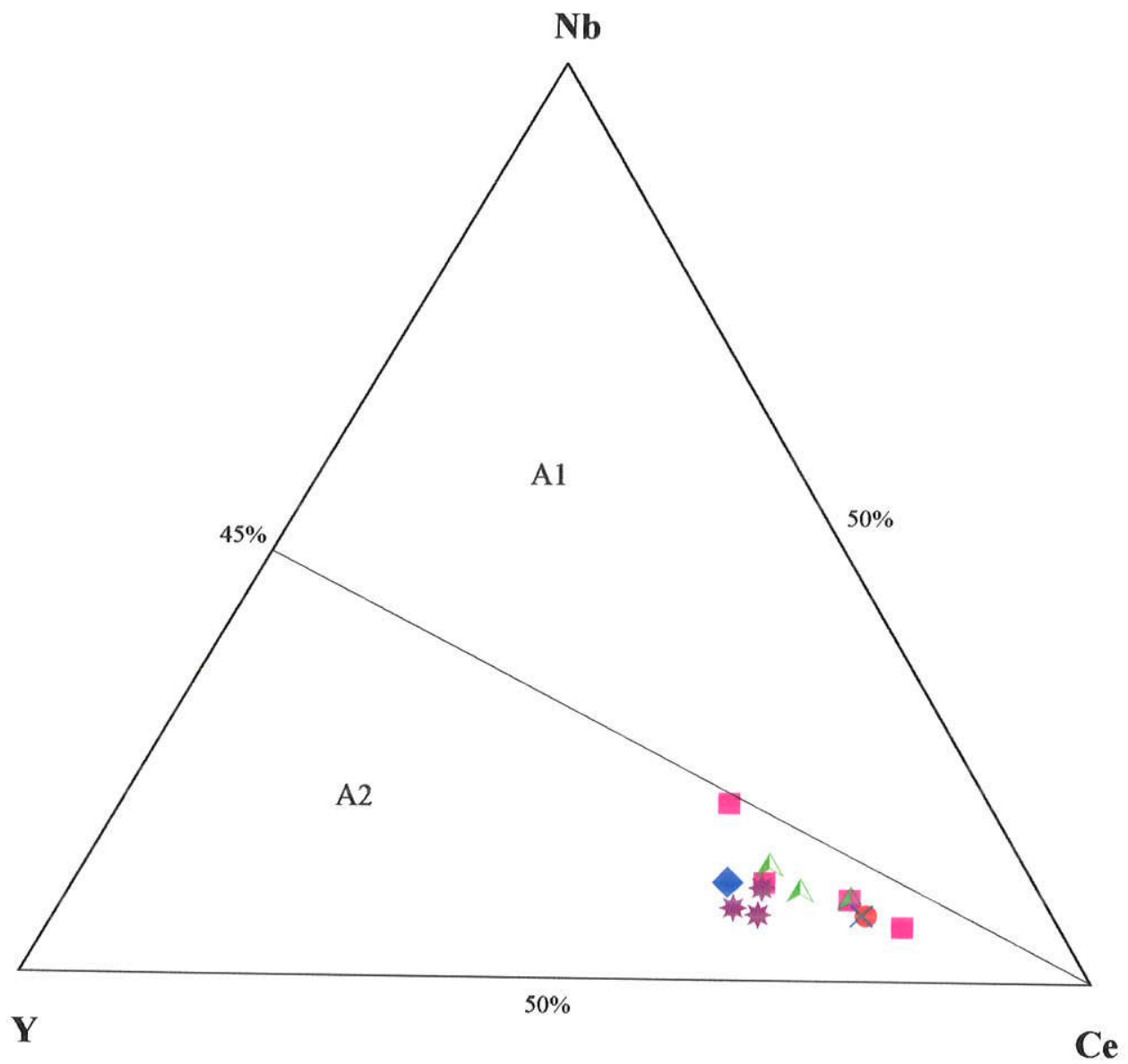

Figura VI.15. Diagrama ternário de variação (Nb-Y-Ce) para as fácies granítica, sieníticas, melasienítica, dioritica/ rochas híbridas e enclave monzonítico. Os campos discriminantes para granitos de Tipo-A, segundo Eby (1992), estão indicados no diagrama.
Granito Sienito róseo
A Sienito Verde
Melasienito
Diorito/Rochas Híbridas
Enclave Monzonítico 


\section{Capítulo VII}

Conclusões 


\section{Sumário e Conclusões}

O Maciço Corupá possui forma semi-anelar e aflora por uma área de aproximadamente $50 \mathrm{Km}^{2}$ na região N-NE do estado de Santa Catarina, no extremo meridional da Província Serra do Mar, esta, por sua vez, constituída por mais de uma dezena de maciços sieníticos e graníticos neoproterozóicos de Tipo-A (Kaul \& Cordani, 2000; Gualda , 2001). O Maciço Corupá é intrusivo em rochas gnáissico-granulíticas, e é constituído por rochas sieníticas, graníticas e subordinadamente por rochas dioríticas e híbridas reunidas em cerca de sete fácies petrográficas da associação alcalina de sienitos e granitos de Tipo-A.

As fácies sieníticas são volumetricamente as mais importantes. Correspondem a álcalifeldspato sienitos e quartzo sienitos com IC entre 5 e 20 , com colorações verdes e róseas e granulações variando de finas, médias a grossas. Uma fácies particular muito escura, de melasienitos, apresenta IC superior a 50.

A fácies granítica, de ocorrência relativamente subordinada, tem IC inferior a 5; apresenta coloração rósea e granulação média. Já as rochas dioríticas, ocorrem como diques e corpos menores cujas formas não foram reconhecidas com precisão, e apresentam granulações finas a médias, com IC entre 10 e 20 . Rochas híbridas (monzodioritos e monzonitos) ocorrem isoladamente e como enclaves arredondados a irregulares de dimensões milimétricas a centimétricas associados as rochas sieníticas róseas de granulação média.

$\mathrm{O}$ volume das rochas sieníticas, muito mais expressivo em relação às graníticas, indica que o termo "Granito Corupá", denominação pioneira de Albuquerque et al. (1971), utilizada por diversos autores como Siga Jr. et al. (1993), Kaul (1997), Kaul \& Cordani (2000), que apesar de prioritária, é pouco apropriada, e desta forma é sugerida a substituição do termo por Maciço Corupá (ver também, Oliveira, 1997; Chiessi et al., 1998).

As relações geológicas entre as diferentes fácies sieníticas e a fácies granítica não foram totalmente elucidadas, devido à escassez de afloramentos e às dificuldades de acesso da área estudada. Algumas inferências geológicas e petrográficas, permitem sugerir que todas estas fácies colocaram-se em períodos muito próximos e/ou simultaneamente, em princípio, as 
variedades mais félsicas cristalizando-se pouco após às variedades mais máficas. Algumas relações observadas entre as rochas dioriticas e híbridas e as rochas sieníticas também suportam uma interpretação deste tipo. Dados estruturais e texturais (ocorrência apenas de sienitos e granitos hipersolvus, presença de cavidades miarolíticas, intercrescimentos granofíricos, etc..) indicam que estas rochas colocaram-se em níveis crustais relativamente rasos.

As fácies sieníticas apresentam a associação primária feldspato alcalino \pm olivina \pm quartzo + clinopiroxênio + anfibólio + ilmenita + chevkinita + apatita + zircão. A fácies melasienítica, com aspecto tipicamente "cumulático", apresenta olivina, clinopiroxênio, magnetita, ilmenita e apatita como fases "cumulus" e feldspato alcalino e biotita como principais fases "intercumulus". As rochas graníticas apresentam feldspato alcalino + quartzo + anfibólio + zircão + chevkinita + apatita + ilmenita. As rochas dioríticas são constituídas em essência por plagioclásio + clinopiroxênio + anfibólio + biotita + ilmenita + magnetita e as rochas híbridas são caracterizadas pelas associações minerais plagioclásio + clinopiroxênio + anfibólio + biotita + ilmenita + magnetita + quartzo + feldspato alcalino.

As tendências modais de variação observadas em diagramas Q-A-P, apesar de compativeis com a tendência da denominada série alcalina de Lameyre \& Bowden (1982) apontam para lacunas composicionais bem marcadas entre as rochas dioríticas e sieníticas e entre estas últimas e as graníticas. A menos de um de artifício de amostragem, estes dados São compatíveis com as seguintes hipóteses:

- as rochas dioríticas foram formadas a partir da cristalização de magmas independentes, de colocação mais ou menos contemporânea, e não fazem parte da mesma linhagem evolutiva das rochas sieníticas e graníticas, mas sim representam um evento discreto. Merece ser destacado que as únicas rochas composicionalmente intermediárias entre os dioritos típicos e os sienitos, os monzodioritos e monzonitos, apresentam-se ou como enclaves ou como ocorrências menores, com evidências estruturais e texturais de processos de mistura e hibridismo com magmas félsicos;

- as rochas graníticas podem ter sido originadas por fracionamento simples de "mushes" sieníticos, conforme sugerido por Kaul (1997) e genericamente demonstrado por Giret et al. (1980); mas, em algum momento, uma fração discreta de liquidus granítico, quantitativamente subordinada, foi individualizada destes "mushes", cristalizando de modo independente. 
O quimismo das principais fases minerais indica que as composições da olivina são mais ricas na molécula de Fayalita na fácies sienítica verde de granulação grossa, quando comparada com fácies melasienítica, entretanto estas variações composicionais não são contínuas, evidenciando-se uma lacuna entre as composições do sienito e do melasienito. As tendências de variação composicional no grupo das rochas sieníticas mostram que, das rochas mais máficas para as mais félsicas, o clinopiroxênio torna-se mais rico na molécula de hedenbergita, alcançando composições de aegirina-augita, os anfibólios variam de cálcicos a cálcio-sódicos e - feldspato alcalino passa para composições mais ricas na molécula de Or. Nas rochas graníticas, o anfibólio varia de cálcico a cálcio-sódico.

As paragêneses minerais observadas no melasienito (olivina + magnetita + ilmenita) e nas rochas sieníticas mais máficas (olivina + quartzo + ilmenita) sugerem que os respectivos magmas cristalizaram em condições próximas, provavelmente pouco inferiores, ao "buffer" QFM. As composições integradas dos feldspatos alcalinos sugerem temperaturas de cristalização superiores a $900^{\circ}$ e entre $800^{\circ}$ e $900^{\circ} \mathrm{C}$ para os melasienitos e sienitos, respectivamente e pouco inferiores para as rochas graníticas. No caso dos dioritos, a presença de anfibólio cálcico, biotita, quartzo, magnetita e ilmenita indica condições de cristalização mais oxidantes.

Os dados geoquímicos indicam que as rochas mapeadas são saturadas a supersaturadas e variam de metaluminosas (dioritos e rochas híbridas, fácies melasienítica e sieníticas mais máficas) a peralcalinas (fácies sieníticas mais félsicas e granítica). A partir destes dados, analisados em diagramas binários simples, pode ser sugerido que:

- a fácies granítica pode ter sido originada por mecanismos simples de cristalização fracionada a partir de "mushes" originalmente sieníticos;

- os magmas sieníticos não devem ter sido originados por cristalização fracionada simples de magmas de composições dioríticas similares às das rochas dioríticas aflorantes no maciço, por extração das fases minerais mais típicas (clinopiroxênio e plagioclásio);

- a coexistência de dois magmas originalmente contrastados, um de composição diorítica, outro de composição sienítica, localmente interagiram e resultaram em variedades híbridas com composições monzodioriticas e monzoníticas; 
- a fácies melasienítica deve ter sido originada por acúmulo de fases minerais máficas (olivina, clinopiroxênio e minerais opacos) cristalizadas a partir de magmas sieníticos;

Alguns dados para elementos terras raras obtidos por Kaul (1997) e Kaul \& Cordani (2000) mostram que pelo menos uma variedade sienítica (sienitos verdes de granulação grossa) não apresentam anomalias negativas de Eu. Este dado sugere pelo menos a possibilidade de que os magmas sieníticos do maciço sejam primários.

As características gerais do Maciço de Corupá são compatíveis com a sua colocação em ambientes pós-colisionais, de acordo com as principais hipóteses vigentes para o magmatismo de Tipo-A geral da Província Serra do Mar (Siga Jr. et. al, 1993; Kaul, 1997; Vlach et al., 1996; Kaul, 1997; Kaul \& Cordani, 2000; Gualda, 2001). 


\section{Referências Bibliográficas}


ALBUQUERQUE, LFF de; ARIOLI, EE; DIAS, A de A; KIRCHNER, CA (1971) "Geologia das quadriculas de Blumenau e Joinville, Santa Catarina". Relatório do Arquivo Técnico da DGM. DNPM/CPRM, Porto Alegre, 1768, 121 p.

ANDERSON, JL (1983) "Proterozoic anorogenic granite plutonism of North America". Geological Society of America Memoir, 161; p. 133-154.

BONIN, B; AZZOUNI-SEKAL, A; BUSSY, F; FERRAG, S (1998) "Alkali-calcic and alkaline post-orogenic (PO) granite magmatism: petrologic constraints and geodynamic settings". Lithos, 45 ; p. 29-44.

CHIESSI, CM; OLIVEIRA, DGG; GUALDA, GAR; VLACH, SRF (1998) "Texturas $e$ quimismo de minerais máficos do Maciço Sienitico Corupá (SC)". Simpósio de Iniciação Científica da USP, 6, São Carlos. USP-CNPq. Resumos..., 2, p. 498.

COX, KG; BELL, JB; PANKHURST, RJ (1979) "The interpretation of igneous rocks". George Allen \&Unwin, London, 450 p.

DAITX, EC (1979) “Mapa geológico, Folha Jaraguá do Sul, SG.22-Z-BI." In: Carvalho, MA da $S$ et al. (1980) "Projeto geoquímica na área de Guaratubinha-Piên".DNPM/CPRM. Relatório Final, 1 , anexo 1, esc.: 1:100000.

DEER, WA; HOWIE, RA; ZUSSMAN, LS (1992) "An introduction to the rock-forming minerals". $2^{\text {nd }}$ edition. Longman Scientific \& Tecnical. 696 p.

DROOP, GTR (1987) "A general equation for estimating $\mathrm{Fe}^{3+}$ in ferromagnesian silicates and oxides from micropobre analysis, using stoichiometric criteria". Mineralogical Magazine, 51, p. $431-437$.

EBY, GN (1992) "Chemical subdivision of the A-type granitoids: petrogenetic and tectonic implications". Geology, 20; p. 641-644.

EBY, GN (1990) "The A-type granitoids: A review of their occurrence and chemical characeristics and speculations on their petrogenesis". Lithos, 26; p. 115-134.

ELKINS,LT; GROVE, TL (1990) "Ternary feldspar experiments and thermodynamic models". American Mineralogist, 75; p. 544-559.

GIRET, A; BONIN, B; LEGER, J-M (1980) "Amphibole composicional trends in oversaturated and undersaturated alkaline plutonic ring-complexes". Canadian Mineralogist, 18, p. 481495.

GUALDA, GAR (2001) "Evolução petrográfica e mineralógica das associações alcalina e aluminosa dos granitos de Tipo-A da Graciosa, PR”. Dissertação de Mestrado. Programa de Pós-graduação em Mineralogia e Petrologia. IGc - USP. Inédita.

GUALDA, GAR; VLACH, SRF (Inédito) "MINCAL" Windows Software. 
HOGAN, MC; GILBERT, MC; WEAVER, BL (1992) "A-type granites and rhyolites: is A for ambiguous?". EOS, 73; p. 508.

IRVINE, ,TN; BARAGAR, NR (1971) "A guide to classification of common volcanic rocks" Canadian Journal of Earth Sciences, $\underline{8}$, p. 523-548.

JANASI, VA; ANDRADE, S; ULBRICH, HHGJ (1995) "A correção do drift instrumental em ICP-AES com espectrômetro seqüencial e análise de elementos maiores, menores e traços em rochas" Boletim IG-USP, Série Científica , 26, p. 45-58.

KAUL, PFT (1997) "O magmatismo na Serra Do Mar e adjacências (sul do Brasil) no final Neoproterozóico e seus condicionantes tectônicos". Tese de Doutoramento. de Pósgraduação em Geoquímica e Geotectônica. IGc - USP. 293 p..

KAUL, PFT (1984) "Significado dos granitos anorogênicos da suite intrusiva Serra do Mar na evolução da crosta no sul-sudeste do Brasil, no âmbito das Folhas SG.22-Curitiba e SG.23Iguape". Anais: Congresso Brasileiro de Geologia, 33, Rio de Janeiro, 12v., 6, p. 2815 2825 .

KAUL, PFT; CORDANI, UG (2000) "Geochemistry of the Serra do Mar (Southern Brazil) granitoid magmatism and tectonic implications". International geological congress, 31, Rio de Janeiro, CD-rom.

KRETZ, R (1983) “Mineral Abreviationst" American Mineralogist, 68.

LAMEYRE, J; BOWDEN, P (1982) "Plutonic rock types series: discrimination of various granitoid series and related rocks". Journal of Volcanology and Geothermal Research, 14; p. 169-189.

LEAKE, BE et al. (1997) "Nomenclature of amphiboles: report of the subcommittee on amphiboles of the International Mineralogical Association, commission on new minerals and mineral names". Canadian Mineralogist, $\underline{35}$, p. 219-245.

LOISELLE, MC; WONES (1979) "Chacteristics and origin of anorogenic granites". Geological Society of America Abstract, 11, 468.

MAACK, R (1961) "Sobre a ocorrência de granitos alcalinos no Estado do Paraná e sua posição dentro das fases orogen 'ticas algonquianas". Boletim da UFPR. Geologia, 4. p. 152.

MACKENZIE, WS; DONALDSON, CH; GUILFORD, C (1993) "Atlas of igneous rocks and their texture". Longman Scientific \& Tecnical. 148 p..

MANIAR, PD \& PICCOLI, PM (1989) “Tectonic discrimination of granitoids". Geological Society of America Bulletin, 101, p. 635-643.

MIDDLEMOST, EAK (1985) "Magmas and magmatics rocks. An introdution to igneous petrology”. Longman Scientific \& Tecnical. 266 p.. 
MORI, PE; REEVES, S; CORREIA; CT; HAUKKA, M (1999) "Development of a fused glass disc XRF facility and comparison with the pressed powder pellet technique at nstituto de Geociencias, São Paulo University". Revista Brasileira de Geociências, 29 (3), p. 441-446.

MORIMOTO, N (1990) "Nomenclatura de piroxênios". Tradução do original em inglês "Nomenclature of pyroxenes", realizada com a permissão do IMA por GARDA, MG \& ATENCIO, D. Revista Brasileira de Geociências, 20 (1-4), p. 318-328.

OLIVEIRA, DG (1997) "Petrografia e quimismo de fases minerais máficas em amostras selecionadas do Granito Corupá (SC)". Relatório de Iniciação Científica. PIBIC-CNPqUSP. Inédito. $34 \mathrm{p}$..

PEARCE, J.A.; HARRIS, N.B.W.; TINDLE, A.G. (1984) "Trace element discrimination diagrams for the tectonic inerpretation of granit rocks" Journal of Petrology, $\underline{25}$, p. 956983.

PECCERILLO, A; TAYLOR, SR (1976) "Geochemistry of Eocene calc-alkaline volcanic rocks from the Kastamoru area, nothern Turkey" Contributions to Mineralogy and Petrology, $\underline{58}$, p. $63-81$.

RICHARD, LR (1995) "MINPET 2.02 - Mineralogical and Petrological Data Processin System". Windows Software.

SCHUMACHER, JC (1997) "Appendix 2. The estimation of the proportion of ferric iron in the electron-microprobe analysis of amphiboles". In: Leake, BE (chairman) (1997) "Nomenclature of amphibole". Canadian Mineralogist, 35, 238-246.

SIGA JR., O (1995) "Domínios tect6onicos do sudeste do Paraná e nordeste de Santa Catarina: geocronologia e evolução crustal". Tese de Doutoramento. Programa de Pós-graduação em. Geoquímica e Geotectônica. IGc - USP. Inédita. 164 p..

SIGA Jr., O.; BASEI, M.A.S.; MACHIAVELLI, A. (1993) "Evolução tectônica da NE de Santa Catarina e SE do Paraná, com base em interrpretações geocronológicas". Revista Brasileira de Geociências, 23(3) . p. 215-223.

SMITH, JV; BROWN, WL (1988) "Feldspar Minerals". Springer-Verlag. 1, 828 p..

STRECKEISEN, AL (1973) "Plutonic rocks: classification and nomenclature recommended by the IUGS Subcomission of the systematic of igneous rocks". Geotimes, $18,26-30$.

TRÖGER, WE (1979) “Optical determination of rock forming minerals". E. Schweizerbart'scheverlagsbuchhandlung, $188 \mathrm{p}$.

TUTTLE, OF; BOWEN, NL (1958) "Origin of granite in the light of experimental studies in the system $\mathrm{NaAlSi}_{3} \mathrm{O}_{8}-\mathrm{KAlSi}_{3} \mathrm{O}_{8-} \mathrm{SiO}_{2}-\mathrm{H}_{2} \mathrm{O}$ ”. Geological Society of America Memoir, 74, 153 p.. 
ULBRICH, HHGJ; VLACH, SRF; JANASI, VA. (2001) "O mapeamento faciológico em rochas igneas plutônicas”. Revista Brasileira de Geociências, 31(2), p. 163-172.

VLACH, SRF (1999) "Ocorrência e variações composicionais de chevkinita-Ce e allanita(-Fe) em quartzo-sienitos do Maciço Corupá (SC), Província Serra do Mar”. Anais do V Congresso de Geoquímica dos Países de Língua Portuguesa, p. 627-630.

VLACH, SRF (1993) “Geologia e petrologia dos granitóides de Morungaba, SP". Tese de Doutoramento. Programa de Pós-graduação em Mineralogia e Petrologia. IGc - USP. Inédita. $414 \mathrm{p}$.

VLACH, SRF (1985) "Geologia, petrografia e geocronologia das regiões meridional e oriental do complexo de Morungaba, SP". Dissertação de Mestrado. Programa de Pós-graduação em Mineralogia e Petrologia. IGc - USP. Inédita. 253 p..

VLACH, SRF, JANASI, VA, ULBRICH, HHGJ (1996) "Ages and typology of the Brasiliano granitic magmatism close tothe Proterozoic-Phanerozoic boundary, States of São Paulo and Paraná, SE-Brazil". Anais da Academia Brasileira de Ciências, 68, 4; p. 597-598.

WEN, S; NEKVASIL, TM (1994) "SOLVCALC: an interactive graphics package for ternary feldspar calculations and geothermometrys". Computers \& Geoscience, 20, p. 1025-1040.

WHALEN, JB; CURRIE, KL; CHAPPEL, BW (1987) "A-type granites: Geochemical characteristics, discrimination and petrogenesis". Contributions to Mineralogy and Petrology, 95; p. 407-419.

WILLIANS, H; TURNER, FJ; GILBERT, CM (1982) "Petrography - A Intoduction to the Study of Rocks in Thin Sections" Second edition W. H. Freemam New York 626p. 